\title{
Range Plant Community Types and Carrying Capacity for the Montane Subregion
}

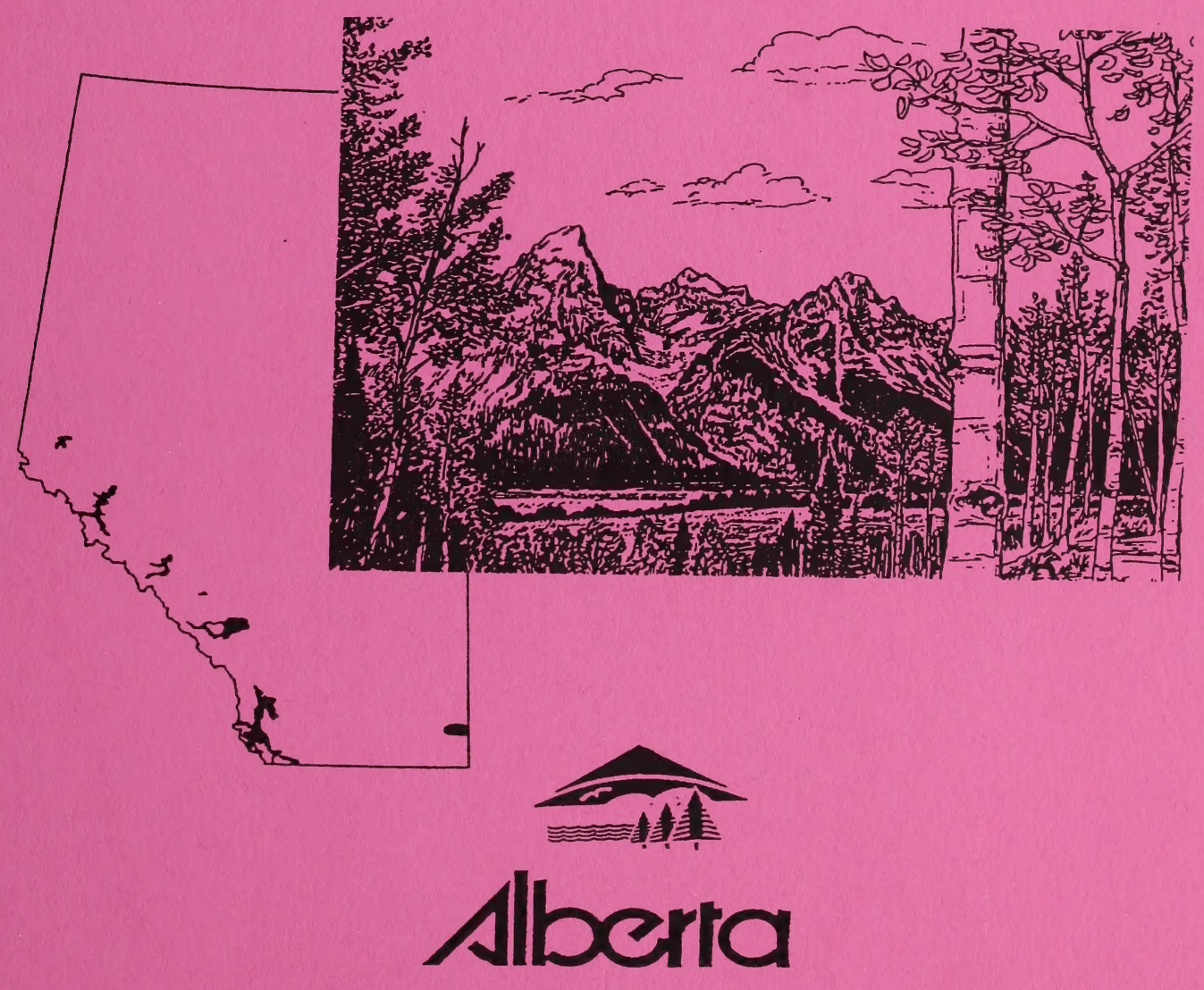

Sustainable Resource Development 



\section{RANGE PLANT COMMUNITY TYPES AND CARRYING CAPACITY FOR THE MONTANE SUBREGION}

\section{Fifth approximation}

(Please note this edition is a revision of the $2^{\text {nd }}, 3^{\text {rd }}$ and $4^{\text {th }}$ approximations of the Range plant community types and carrying capacity for the Montane subregion.

Pub. no. T/343, T/433 and T/589)

2003

Prepared by

Michael G. Willoughby,

Michael J. Alexander

and

Barry W. Adams

Edmonton

2003
Sustainable Resource Development Public Lands Division 
Digitized by the Internet Archive in 2015 
Pub. no.: T/033

ISBN: 0-7785-2337-3

For copies of this report contact:

Michael Willoughby

9920108 st, 9th Floor

Edmonton, Alta.

T5K2M4

(403) 422-4598

E-mail: mwilloug@gov.ab.ca 


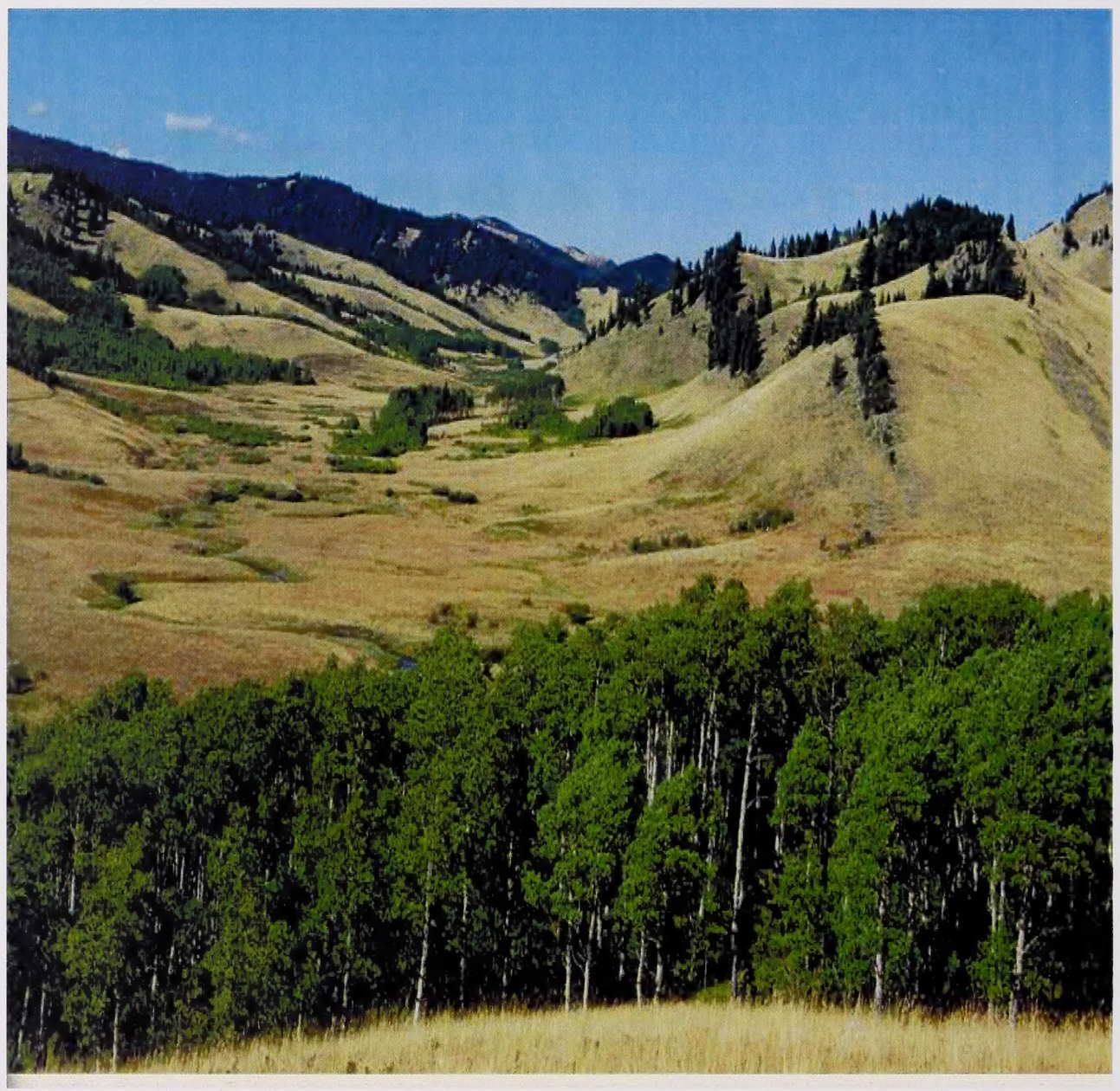

Photo 1. Rolling topography of the Montane subregion: This illustrates the grassland-shrubland and grassland-forest ecotones of the Montane subregion. 


\section{Table of contents}

Introduction

Climate of Montane subregion

Methods

How to use guide

Results

Montane Grassland Ecology

Key to native grasslands

Key to grassland community types in the Banff and Jasper Mountain ecodistricts

Key to the grassland communities in the Cypress Hills ecodistrict

A. Banff and Jasper Mountain ecodistricts grassland community types

A1. Fringed sage/Junegrass

$\begin{array}{ll}\text { A2. Northern wheatgrass-Sheep fescue } & 57\end{array}$

A3. Small-leaved everlasting/Junegrass 58

A4. Creeping juniper/Northern wheat grass-Columbia needle grass $\quad 59$

A5. Prairie selaginella/Richardson needlegrass $\quad 60$

A6. Kentucky bluegrass-June grass/Dandelion 61

A7. Bearberry-Juniper $\quad 62$

A8. Prickly rose-Snowberry 63

$\begin{array}{ll}\text { Ya Ha Tinda Area } & 63\end{array}$

A9. Tufted hairgrass-Sedge $\quad 65$

A10. Bog birch/Sedge-Rough fescue 66

$\begin{array}{ll}\text { A11. Rough fescue-Fringed brome-Sedge } & 67\end{array}$

A12. Rough fescue-Sedge-Junegrass 68

$\begin{array}{ll}\text { A13. Sedge-Junegrass } & 69\end{array}$

A14. Creeping red fescue-Timothy 70

B. Blairmore and Morley Foothills ecodistricts grassland community types 
B1. Rough fescue-Idaho fescue-Parry oatgrass 72

B2. Idaho fescue-Parry oatgrass-Rough fescue 73

B3. Bluebunch wheatgrass-Sedge $\quad 74$

B4. Rough fescue-Sedge/Bearberry 75

B5. Big sagebrush/B. wheatgrass-Sedge 76

B6. Snowberry-Rose-Saskatoon/Bearberry 77

B7. Pinegrass-Hairy wildrye/Strawberry $\quad 78$

B8. Douglas fir/Idaho fescue-Rough fescue $\quad 79$

B9. Douglas fir//daho fescue-Sandberg bluegrass $\quad 80$

B10. Aw/Strawberry/Rough fescue 81

B11. Thimbleberry brush $\quad 82$

B12. Beaked-Water Sedge 83

B12a. Awned Sedge $\quad 84$

B13. Tufted hairgrass-Baltic rush 85

B13a. Baltic rush $\quad 86$

B14. Forb meadows $\quad 87$

B15. Rough fescue-Hairy wildrye $\quad 88$

B16. Big sagebrush-Buckthorn/Kentucky bluegrass $\quad 89$

B17. Creeping spike rush 90

B18. Small fruited bulrush 91

B19. Great bulrush $\quad 92$

B20. Cattail 93

C. Blairmore and Morley Foothills ecodistricts disturbed grassland community types 94

C1. Idaho fescue-Parry oatgrass-Sedge 95

C2. Canada bluegrass-Rough fescue 96

C3. Kentucky bluegrass-Rough fescue 97

C4. Kentucky bluegrass-Timothy/Dandelion 98

C5. Smooth brome-Kentucky bluegrass 99

C6. Blunt sedge/Little clubmoss/Moss phlox $\quad 100$

C7. Creeping red fescue/Dandelion-Clover 101

C8. Northern wheatgrass-Kentucky bluegrass 102

C9. Rough fescue-Kentucky bluegrass 103

C10. Rough fescue-Sedge-Mountain brome 104

C11 Snowberry/Kentucky bluegrass 105

C12 Aw/Orchardgrass-Kentucky bluegrass 106

$\begin{array}{ll}\text { D. Montane Shrubland ecology } & 107\end{array}$

$\begin{array}{ll}\text { Key to Montane shrublands } & 109\end{array}$ 
D1. Yellow mountain avens-River alder/Low forb 112

D2. Yellow mountain avens/Junegrass 113

D2a. Drummond's willow 114

D3. Bebb willow/Hairy wildrye 115

D3a Bebb willow/Sedge 116

D4. Bebb willow/Kentucky bluegrass 117

D5. Green alder-Scouler's willow-Wild red rasp'uerry 118

D6. Flat leaved willow/Quackgrass-Kentucky bluegrass 119

D7. Flat leaved willow/Horsetail/Sedge 120

D8. Myrtle leaved willow/Sedge 121

D9. Basket willow/Sedge 122

D9a. Basket willow/Kentucky bluegrass 123

D10. Dwarf birch-Shrubby cinquefoil/Northern valerian/Sedge 124

D11. White spruce-Willow/Water sedge/Golden moss 125

D12. Black spruce/Myrtle leaved willow/Wire rush-Sedge/Moss $\quad 126$

D13. Water birch-Smooth willow/Pinegrass 127

D14. Hawthorn-Snowberry/Kentucky bluegrass 128

$\begin{array}{ll}\text { Montane forest ecology } & 129\end{array}$

$\begin{array}{ll}\text { E. Coniferous community types } & 135\end{array}$

Key to the Coniferous Community types of the Montane subregion $\quad 136$

E1. Pf/Rough fescue 137

E2. Pf-Fd/Juniper/Bearberry 138

E3. P1/Bearberry-Juniper 139

E4. Sw-P1/Alder/Bearberry 140

E5. P1/Buffaloberry/Pinegrass 141

E6. Fd/Hairy wildrye $\quad 142$

E6a Fd/Needle litter 143

E6b Fd/Timothy 144

E7. P1/Low Bilberry/Hairy wildrye 145

E8. P1/White meadowsweet 146

E9. P1/Pinegrass 147

E10. Sw-Fd/White meadowsweet 148

E10a Fd/Snowberry 149

E11. P1/Moss 150

E12. Sw/Moss 151

E12a. Sw/Horsetail 152

E12b. Sw/Silverberry/Horsetail 153

E13. P1/Thimbleberry 154

E14. Pl/Thimbleberry/Beargrass 155 
E15. P1/River alder-Thimbleberry 156

E16. Sw/Thimbleberry 157

E17. Sb-Lt/Labrador tea 158

Castle

E18. Se/Grouseberry 159

E19. Se/Moss 160

E20. Fa-Pl-Sw/White meadowsweet/Pinegrass 161

E21. Fa-Se/Arnica 162

E22. Se/Clover-Oxeye daisy 163

$\begin{array}{ll}\text { F. Mixedwood community types } & 164\end{array}$

Key to the Mixedwood community types of the Montane subregion 165

F1. Aw-Fd/Bearberry 166

F2. Sw-P1-Pb/Yellow Mtn. avens 167

F3. Aw-P1/Buffaloberry/Hairy wildrye 168

F4. Aw-P1/Pinegrass 169

F4a Fd-Aw/Pinegrass $\quad 170$

F5. Aw-Sw/Blueberry 171

F6. Aw-Fd/White meadowsweet 172

F7. Aw-Pb-Sw/Pinegrass 173

F8. Aw-Fa/Snowberry/Pinegrass $\quad 174$

F8a Aw-Pl/Marsh reedgrass $\quad 175$

F9. Pl-Aw/Snowberry/Kentucky bluegrass 176

F10. Aw-Fa-Se/Timothy 177

F11. Spruce-Pb/Snowberry 178

F12. Sw-Aw/Scouring rush $\quad 179$

$\begin{array}{ll}\text { G. Deciduous community types } & 180\end{array}$

Key to the Deciduous community of the Montane subregion 181

G1. Aw/Bearberry/Rough fescue $\quad 182$

G2. Aw/Rose/Hairy wildrye $\quad 183$

G3. Aw/Hairy wildrye 184

G4. Aw/White meadowsweet/Pinegrass $\quad 185$

G5. Aw/Rose/Pinegrass 186

G6. Aw/Pinegrass-Kentucky bluegrass $\quad 187$

G7. Aw/Timothy-Kentucky bluegrass 188

G8. Aw/Snowberry-Saskatoon 189

G9. Aw/Snowberry/Kentucky bluegrass 190 
$\mathrm{G9a} \mathrm{Aw}-\mathrm{Pb} / \mathrm{Marsh}$ reedgrass $\quad 191$

G10. Aw/Thimbleberry 192

G11. Aw/Cow parsnip 193

G12. Pb/Thimbleberry $\quad 194$

G13. $\mathrm{Pb} /$ Cowparsnip/Kentucky bluegrass $\quad 195$

G14. Pb/Snowberry/Kentucky bluegrass 196

$\begin{array}{ll}\text { G15. Aw/Birch-Willow } & 197\end{array}$

H. Cutblocks 198

Cutblocks in Gap area

H1. Pine blocks $\quad 200$

H2. Pine-Spruce blocks 201

Cutblocks in Castle area

H3. Kentucky bluegrass-Timothy 202

H4. Creeping red fescue 203

H5. Beaked sedge $\quad 204$

H6. Subalpine fir 205

H7. Pine-Spruce/Pinegrass 206

Cutblocks in Porcupine Hills

H8. Spruce-Pine blocks $\quad 207$

H9. Douglas-fir blocks 208

I. Cypress Hills community types 209

Key to the grassland community types of the Cypress Hills 212

I1. Foothills fescue-Western Porcupine grass 213

I2. Shrubby cinquefoil/Foothills rough fescue-Intermediate oatgrass $\quad 214$

I3. Shrubby cinquefoil/Foothills rough fescue/Golden bean 215

I4. Shrubby cinquefoil/Foothills rough fescue-Idaho fescue 216

I5. Snowberry/Kentucky bluegrass-Timothy 217

$\begin{array}{ll}\text { I6. Silverberry/Kentucky bluegrass } & 218\end{array}$

$\begin{array}{ll}\text { I7. Pl-Aw/Bunchberry/Moss } & 219\end{array}$

$\begin{array}{lr}\text { Literature cited } & 220\end{array}$ 


\section{List of Figures}

Figure 1. Ecology of the grassland community types in the Foothills ecodistricts of the Montane subregion

Figure 2. Ecological sequence of the grassland-forest transition communities in the Montane subregion

Figure 3. Landscape profile of the Montane shrubland community types

Figure 4. Ecological sequence of the Montane subregion along an environmental gradient

Figure 5. Landscape profile of the forested community types in the Montane subregion

\section{List of Tables}

Table 1. Ecosites, ecosite phases and plant community types for the Montane subregion.

Table 2. Grassland community types of the Montane subregion

Table 3. Shrubland community types of the Montane subregion 108

Table 4. Forested community types of the Montane subregion

Table 5. Cutblock community types of the Montane subregion

Table 6. Plant community types of the Cypress Hills ecodistrict

\section{List of Maps}

Map 1. Location of Montane subregion in Alberta

\section{List of Photos}

Photo 1. Rolling topography of the Montane subregion: Illustrates the grass land-shrubland and grassland-forest ecotones 
Photo 2. Banff and Jasper Mountain ecodistricts. This is a typical grassland of south-facing slopes in Jasper National Park

Photo 3. Banff and Jasper Mountain ecodistricts. Typical grasslands of south-facing slopes and meadows in the Ya Ha Tinda.

Photo 4. Blairmore foothills ecodistrict: Limber pine scattered throughout a Rough fescue-Sedge/Bearberry grassland

Photo 5. Blairmore foothills ecodistrict: A moderately grazed Idaho fescue-Parry oatgrass-Rough fescue grassland.

Photo 6. Blairmore foothills ecodistrict: This is an overgrazed grassland. Kentucky bluegrass, dandelion and clover dominate this community type

Photo 7. Montane shrublands: This represents a Basket willow-Bog birch/Sedge community type. These shrublands are found in valley depressions and are wet for much of the year.

Photo 8. Conifer: This represents a Douglas-fir-White spruce community type. Where the canopy opens up, grasses are fairly abundant and provide good forage for wildlife and livestock. In the absence of disturbance, this site will succeed to white spruce

Photo 9. Mixedwood: This is an aspen forest succeeding to white spruce. There is a good forage base under the aspen, however, as the spruce cover increases, productivity will decline and this site will become non-use

Photo 10. Deciduous: This is an Aspen/Cow parsnip community type.

Photo 11. This photo is typical of the mosaic of plant communities in the Cypress Hills 


\begin{abstract}
The Montane subregion is one of the most diverse subregions within the province of Alberta. The ecological diversity of this subregion creates a landscape that consists of a mosaic of different vegetative communities. This diversity means that these lands are valued for a multitude of uses, including summer range for livestock, prime habitat for many species of wildlife, productive watersheds, wood fibre production and recreation. Despite the importance of many of the vegetation types in the Montane for livestock grazing, there is little information available on how grazing influences the plant community. There is little information on forage productivity, carrying capacity and the associated community types that develop through succession or from disturbance including grazing. This lack of information makes it difficult to develop management prescriptions. As a result "Carrying capacity guides" are being developed for each natural and subregion in the province to provide a framework that would easily group the vegetative community types. It is hoped this classification system can be used by field staff to assess carrying capacity and evaluate range health on lands within each region.

This guide represents the analysis of 1233 plots described in the Montane subregion This guide also includes plots done in the Montane subregion of Banff and Jasper National Parks, 8 new community types described in the Ya Ha Tinda area west of Sundre and 7 community types described in the Cypress Hills. The 1233 plots represent 136 community types. These types are split into:
\end{abstract}

A. Native grasslands (Banff and Jasper Mountain ecodistricts)

14 types

B. Native grasslands (Blairmore and Morley Foothills ecodistricts)

22 types

C. Disturbed grasslands (Blairmore and Morley Foothills ecodistricts)

12 types

D. Native shrublands

17 types

E. Conifer types

26 types

F. Mixedwood types

13 types

G. Deciduous types

16 types

H. Cutblocks

9 types

I. Cypress Hills ecodistrict

7 types

The dominant plant species, canopy cover, environmental conditions, response to grazing, forage production and carrying capacity are outlined for each type. 


\section{Acknowledgements}

The creation of this report would not be possible without data collected in other projects. We would like to acknowledge Parks Canada for allowing us to use data from the Ecological Land Classification of Banff and Jasper National Parks (Holland and Coen 1982). Much of the grassland and shrubland vegetation data collected by Ian Corns and Peter Achuff were incorporated into the Banff and Jasper Mountain ecodistricts of this guide. We would like to acknowledge the work done by Bill Thompson and Paul Hansen who completed the Classification and Management of Riparian and Wetland Sites of Alberta's Grassland Natural Region. All plots done in the Montane subregion for this riparian classification were included in this guide. We would like to acknowledge the Rocky Mountain Forest Reserve Range Association for their continued support in supplying inventory data for the update of the various guides found in the Forest Reserve of Southwestern Alberta. We would also like to acknowledge the work of Lindsay Poulin and Darlene Moisey on the Cypress Hills classification and Karen Sundquist on the shrubland classification. 



\section{Introduction}

The province of Alberta is covered by a broad spectrum of vegetation regions from prairie in the South, to alpine vegetation in the mountains and dense forests in the Central and Northern part of the province. These broad vegetation regions have been classified into 20 subregions for the province (Strong and Thompson 1995). Each of the 20 subregions consists of groups of plant communities which are influenced by environmental co.ıditions and human impacts. Intensive management of these regions requires the ability to recognize the vegetative communities that have similar productivities and respond to disturbance in the same way. The increase in use of Alberta's northern forests has recently stimulated efforts to develop detailed classification systems. Some of these classification systems include "Field guide to Forest ecosystems of West Central Alberta" (Corns and Annas 1986) and "Field Guide to Ecosites of Southwestern Alberta" (Archibald et al. 1996).

The vegetative communities in the province of Alberta are highly regarded by most resource managers for their ability to provide a wide variety of benefits. They are a classic example of multiple use land, providing summer range for livestock, prime habitat for many species of wildlife, wood fibre, productive watersheds and recreational areas. Despite the importance of these vegetation types for livestock grazing, there is little information available on how grazing affects their production. Specificaliy, there is little data on the levels of utilization which are detrimental to a plant communities health. There is also little information on forage productivity, carrying capacity and associated community types that occurs with grazing. Traditionally, these community types have been rated at $5 \mathrm{ac} / \mathrm{AUM}$ or $60 \mathrm{ac} / \mathrm{head} / \mathrm{year}$, but recent work has shown that productivity can vary significantly depending upon the ecological conditions of the site.

The purpose of this guide was to develop a framework that would easily group the vegetative community types in the Montane subregion of the province. The ultimate goal is a classification system that can be used by the field staff to assess carrying capacity and evaluate range health on lands within the region.

\section{Climate of Montane subregion}

The Montane subregion composes only 0.9 percent of the province and is found in an area south of Chain Lakes to the Montana border, portions of the Bow and Athabasca river valleys and isolated areas near Ya Ha Tinda and Grande Cache (Map 1) (Strong and Leggat 1992). The Montane is distinguished from the other subregions by the presence of Douglas-fir (Pseudotsuga menziesii), limber pine (Pinus flexilis) and lodgepole pine (Pinus contorta). Elevationally the Montane occurs below the Subalpine in the mountains and above the Foothills Fescue grass and Aspen parkland subregions in southern Alberta.

Yearly precipitation ranges $308 \mathrm{~mm}$ to $1279 \mathrm{~mm}$ with two precipitation peaks occurring in May-June and again in August-September (Strong 1992). Summer monthly temperatures average $11.9^{\circ} \mathrm{C}$ and are $2^{\circ} \mathrm{C}$ warmer than the Subalpine and $2^{\circ} \mathrm{C}$ colder than the Foothills Fescue 
grass subregions. The Montane has the warmest winter temperatures of any forested region in Alberta because of chinook activity and reduced influence of Arctic air (Strong 1992).

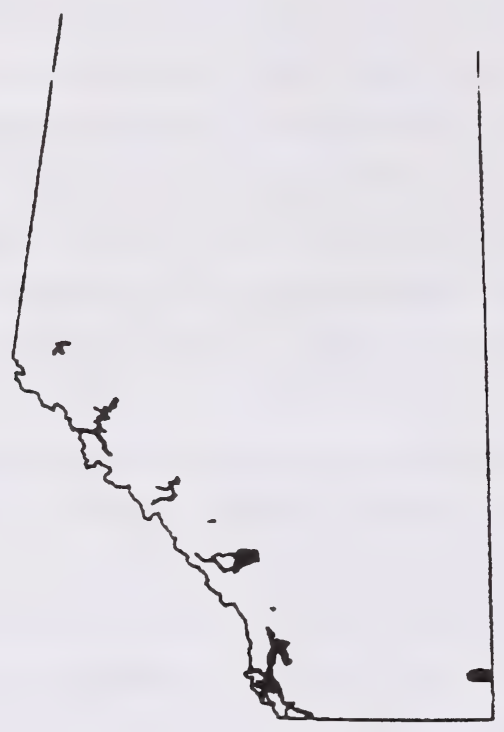

\section{Map 1. Location of Montane subregion in Alberta}

\section{Methods}

A community type approach (Mueggler 1988) to classification was chosen in preference to the habitat type approach (Daubenmire 1952) or ecosystem association approach (Corns and Annas 1986) because of the lack of understanding of the successional sequences of the communities. Community types are aggregates of similar plant communities based upon existing floristics regardless of successional status (Mueggler 1988). Community types are what is actually seen in the field. After defining the community types, they then can be linked to the ecosystem associations. In the mean time community types can be used as the basis for mapping and range management planning.

Initially, grazing dispositions were inventoried by forest region in order to develop management plans following the procedure outlined in the Rangeland Resource Information System (1991). Individual plots were initially classified within a forest region using cluster analysis (SAS) and ordination (DECORANA, Gauch 1982). These types were described in individual carrying capacity guides for each forest. This led to differences in classification of the same types between forests, particularly for deciduous forest types. In an effort to standardize the community name and gain some understanding of each community types ecology, all plots sampled in each forest were reclassified. As the study progressed it became quite evident that 
there were differences in the productivity of the communities between ecoregions. As a result, it was decided to develop the classification within the ecoregion framework (Strong and Leggat 1992). An ecoregion is a geographical area that has broad vegetation zones combined with climatic data (Strong and Anderson 1980). As a result, the vegetation within each ecoregion is strongly influenced by the climatic conditions. Recently, the department has adapted the Natural regions and Subregions of Alberta classification system (Environmental Protection 1994). The Montane subregion and ecoregion share the same boundary.

Sampling for this guide occurred within the Montane subregion. This guide outlines the classification of 1233 plots described in Banff and Jasper National Parks, Southwest region and the Cypress Hills (Southeast region) of the province.

A plot consisted of a $10 \times 10 \mathrm{~m}$ macroplot and ten randomly selected $1 \times 1 \mathrm{~m}$ microplots to record the canopy cover of shrubs and ten nested $20 \times 50 \mathrm{~cm}$ microplots to record the canopy cover of forbs and grass. The inventory followed the Range Survey Manual (1992) and uses the MF5 form. At each macroplot a 50x100 cm was clipped and separated into trees, shrubs, forbs and graminoids, oven dried and weighed. The recommended stocking rate is based on 25 percent of the total production for forested types and $50 \%$ total production for grass and shrubland types and the fact that one animal unit (1000 pd animal) requires $455 \mathrm{~kg}$ of dry weight material for one month of grazing. 


\section{How to use the guide}

Decide what category the community type is in. If it is in the Native grass or Shrub categories it will not have tree cover and be found on steep south facing slopes or moist lowland areas adjacent to streams and rivers. The predominant species will be native grasses, willow and bog birch. The community types described in the native grass and shrub category can be split into the Banff and Jasper Mountain (includes Banff and Jasper National Parks and the $\mathrm{Ya} \mathrm{Ha}$ Tinda) ecodistricts and the Blairmore and Morley Foothills (includes Porcupine Hills, Whaleback and Castle) ecodistricts. The Disturbed grassland community types will resemble the native grassland community types, but will show signs of extensive grazing pressure. These community types will be dominated by grazing resistant species Kentucky bluegrass, clover and dandelion. A couple of moderately grazed community types with a predominant native species cover are also found in this category.

The Deciduous category will be plant communities dominated by deciduous tree species aspen and balsam poplar and the Conifer category will be plant communities dominated by subalpine fir, Engelmann or white spruce, lodgepole pine, limber pine, black spruce, larch or Douglas fir tree species. The Mixedwood category will contain communities that will have at least $50 \%$ of the total tree cover as conifer or deciduous. The Cutblock category contains the types that have had timber harvesting. Finally, new community types that were described in the Cypress Hills are outlined in the Cypress Hills category of the guide.

In order to understand how the community types in this guide are related to the ecosites and ecosite phases outlined in "Ecosites of Southwestern Alberta" (Archibald et al. 1996), the community types in this guide are arranged by ecosite and ecosite phase (Table 1). Ecosites are defined as ecological units that develop under similar environmental influences (climate, moisture and nutrient regime). An ecosite phase is a subdivision of the ecosite based on the dominant species in the canopy. Table 1 is a reproduction of Figure 17 in the Ecosites of Southwestern Alberta guide with the community types in this guide highlighted in the range plant community type and grazing succession categories (Table 1). For the most part the ecosites and ecosite phases are the same, particularly for the forested community types, but a number of new ecosites and ecosite phases had to be created for the grass and shrubland community types (Table 1). The ecosites included (aa)(subxeric/medium) bluebunch wheatgrass, (cc)(submesic/rich) rough fescue grassland, (g) meadow (subhygric/very rich), (h) horsetail (hygric/rich) and (ij) fen (subhydric/rich). The (g) meadow, (h) horsetail, and (ij) fen ecosites are similar to the (e) meadow, ( $\mathrm{f}$ ) horsetail and ( $\mathrm{g}$ ) fen ecosites found in the guide Ecosites of West-Central Alberta (Beckingham et al. 1996). The ecosite phases include (aa1) bluebunch wheatgrass, (aa2) big sagebrush, (b4) yellow mtn. avens, (b5) bearberry grassland, (c5) grassland, (cc1) rough fescue grassland, (d4) white meadowsweet Aw, (d5) shrubland, (d6) grassland (e4) shrubland, (g1) shrubland, (g2) grassland, (h2) horsetail Sw, (h3) horsetail shrubland, (ij1) treed fen, (ij2) shrubby fen and (ij3) graminoid fen. The "Grazing succession" category (Table 1) outlines the successionl sequence the community type will undergo with increased grazing pressure. A number of grazed ecosite phases were included here. These included: (aala) grazed grassland, (ccla) grazed rough fescue, (d3a) cultivated Sw, (d4a) grazed Aw, (d5a) grazed shrubland, (e2a) grazed $\mathrm{Aw}$, (fla) grazed $\mathrm{Pb}$, and (gla) grazed shrubby meadow 


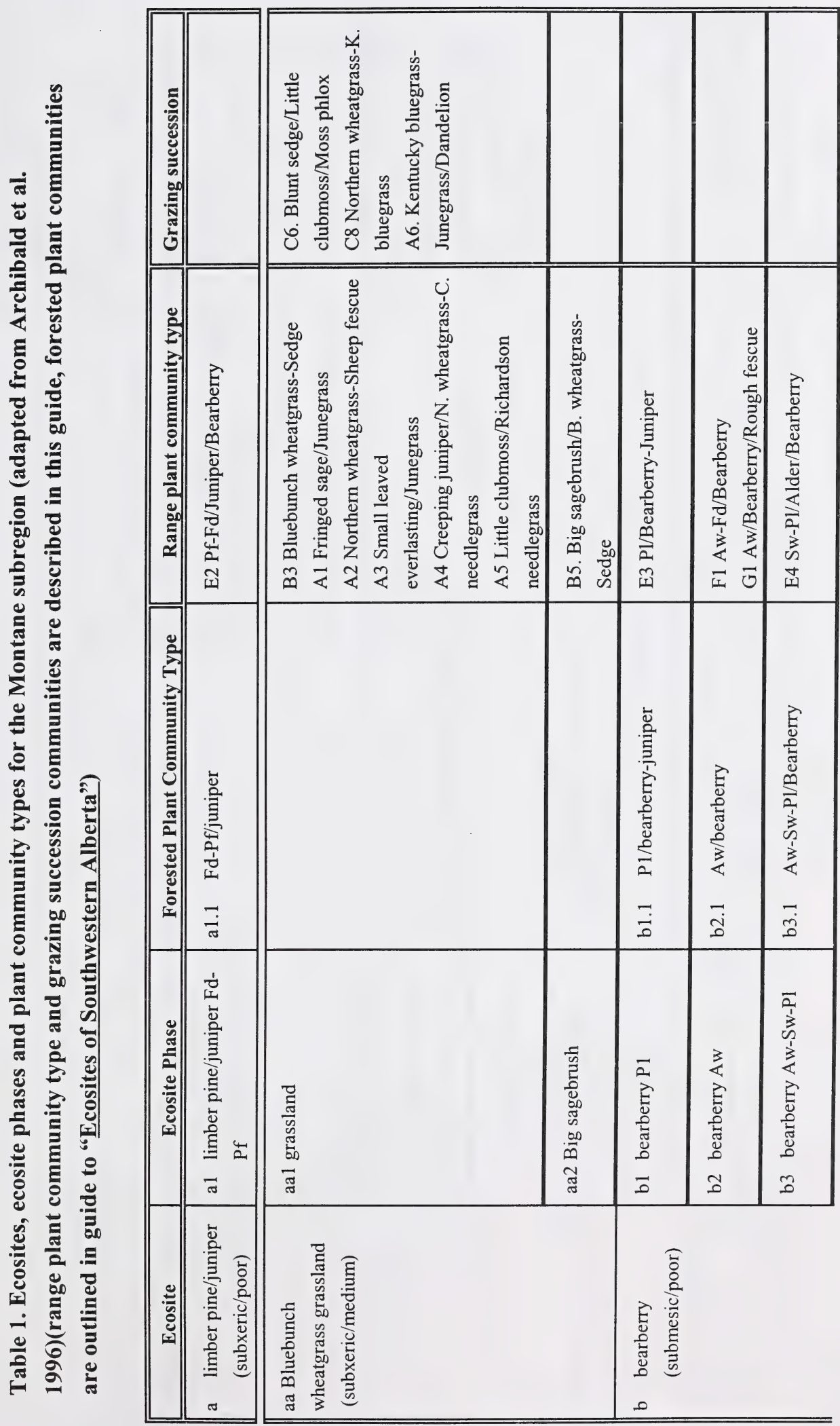




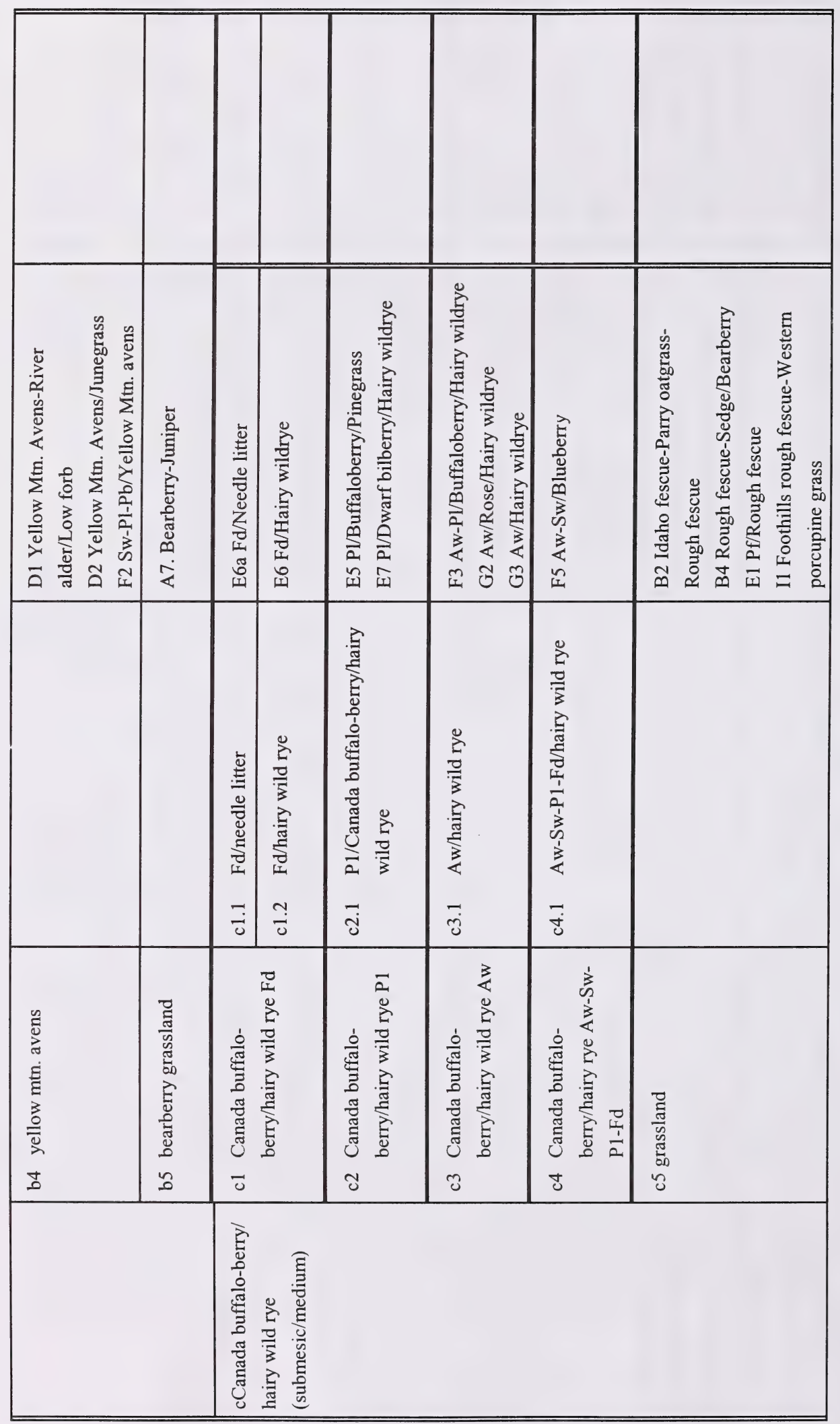





\begin{tabular}{|c|c|c|c|c|c|c|c|c|}
\hline & & 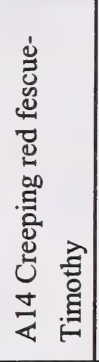 & 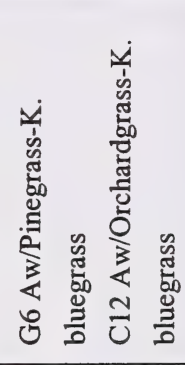 & 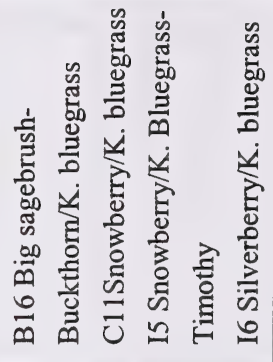 & & & & 辛 \\
\hline & 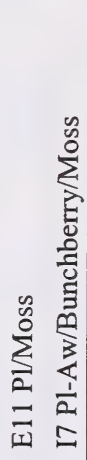 & 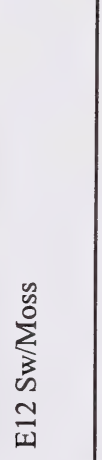 & 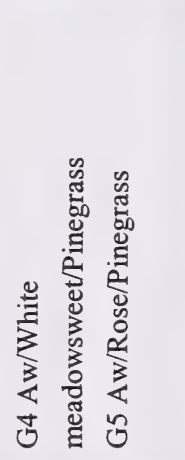 & 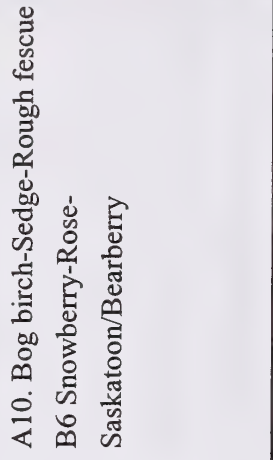 & 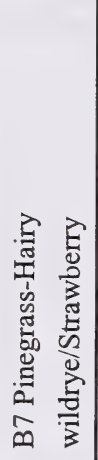 & 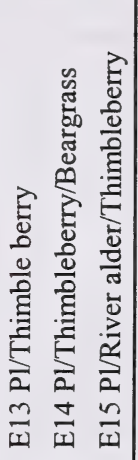 & 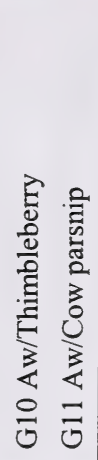 & 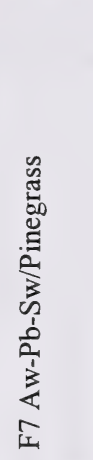 \\
\hline 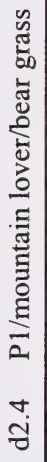 & 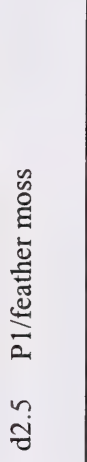 & 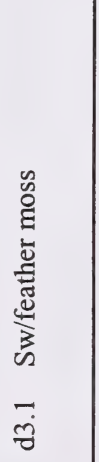 & & & & 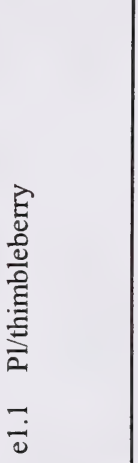 & 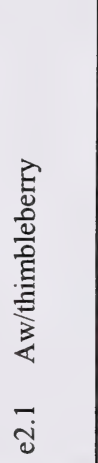 & 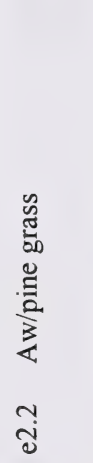 \\
\hline & & 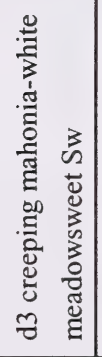 & 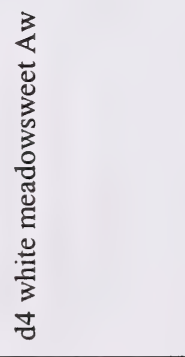 & 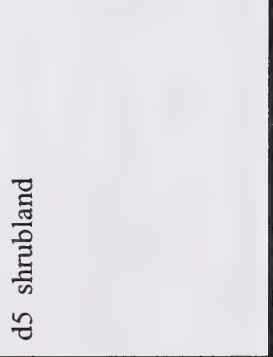 & 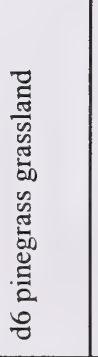 & 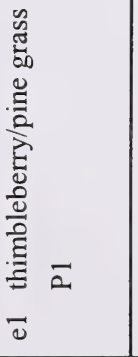 & 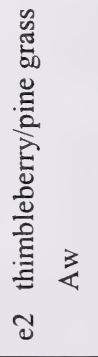 & \\
\hline & & & & & & \multicolumn{3}{|l|}{ 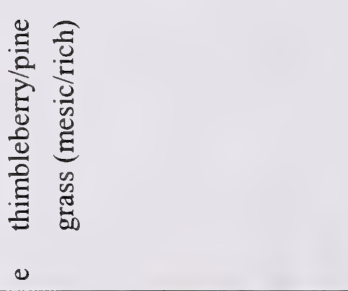 } \\
\hline
\end{tabular}




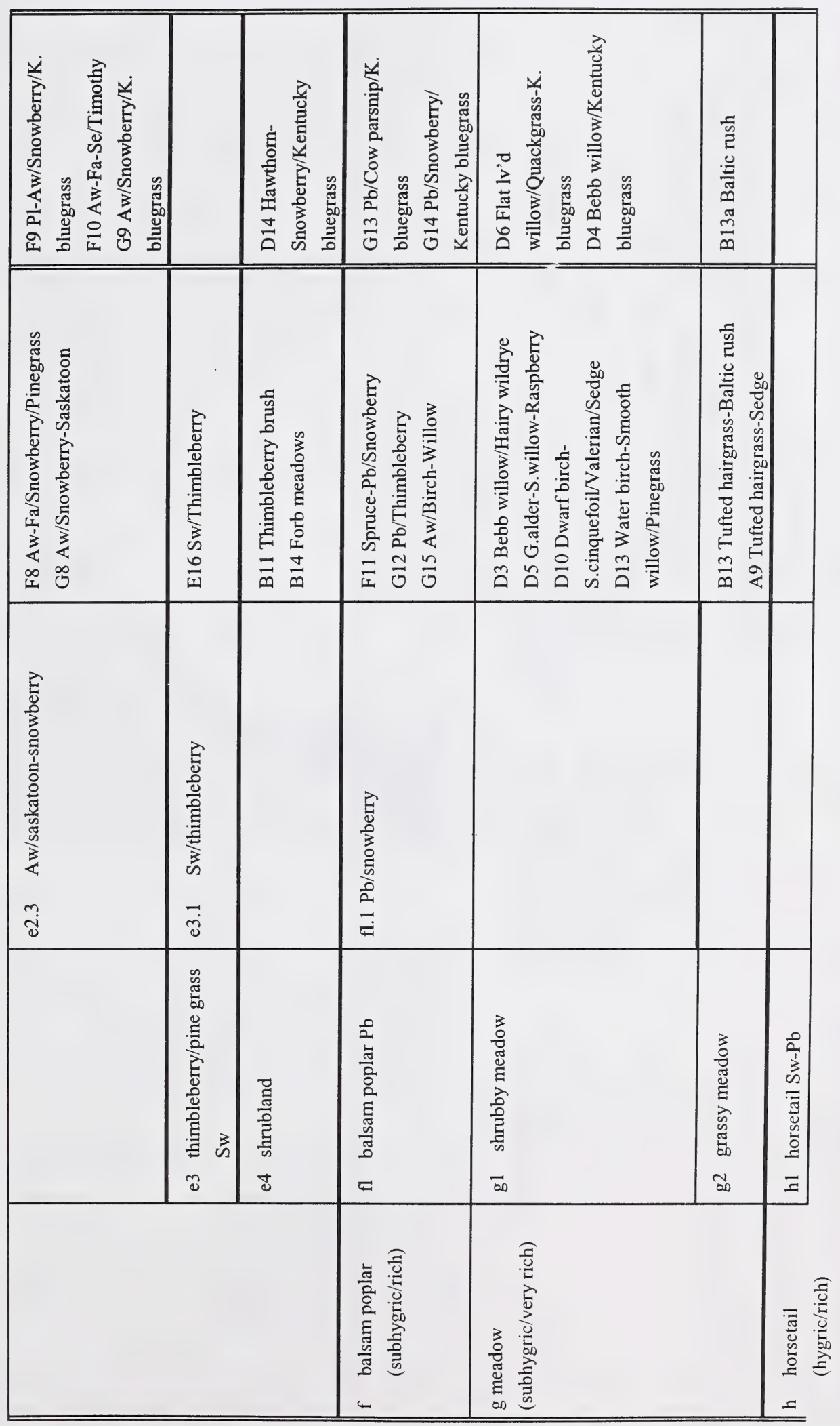




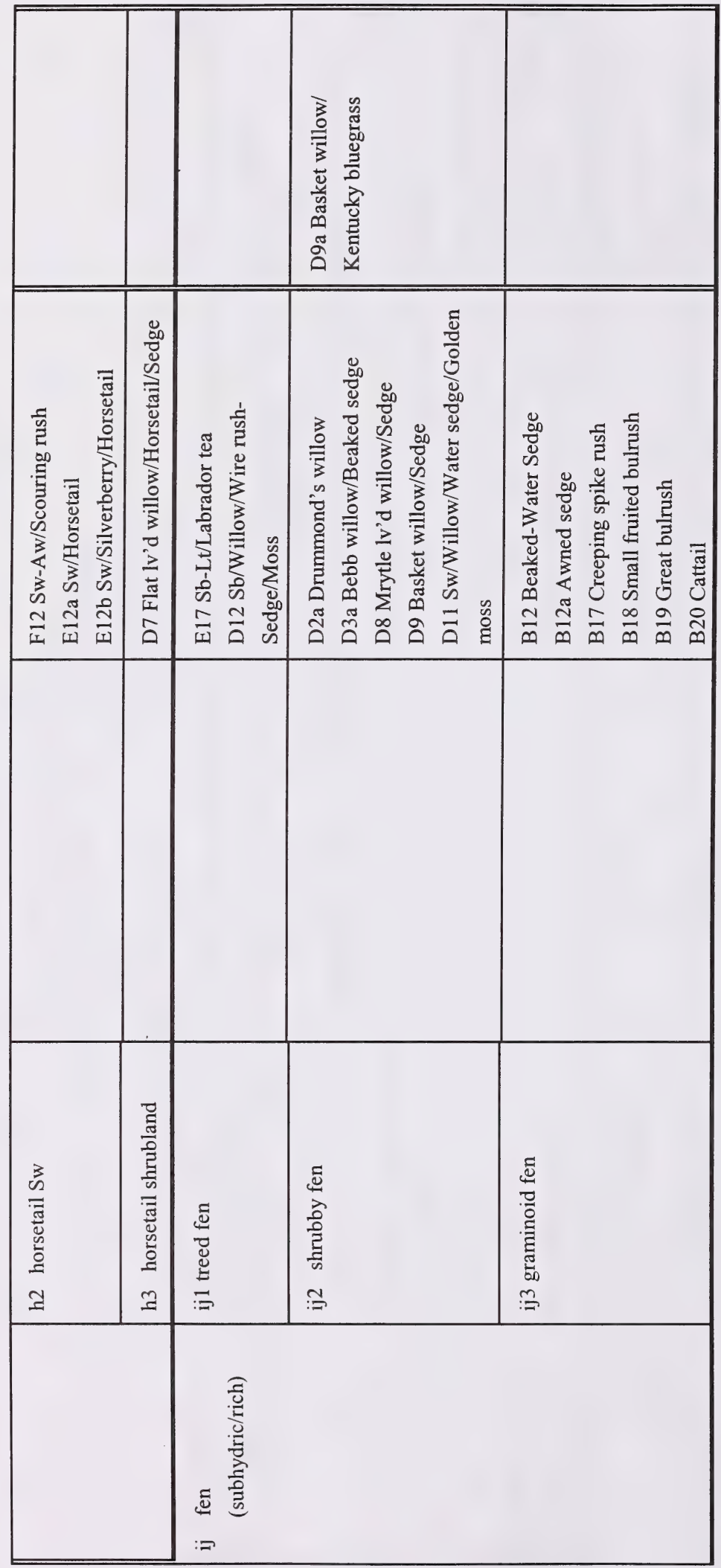




\section{aa \\ Bluebunch wheatgrass $(n=56)$}

\section{GENERAL DESCRIPTION}

This ecosite is located on steep, south and west facing slopes throughout the Blairmore and Morley Foothills ecodistricts and the Banff and Jasper Mountain ecodistricts. The soils are poorly developed, nutrient poor and generally have xeric or subxeric moisture regimes. The grassland communities of the Banff and Jasper Mountain ecodistricts are often dominated by northern wheatgrass, junegrass, fringed sage, sheep fescue and upland sedge species. In contrast the Blairmore and Morley foothills ecodistricts are often dominated by bluebunch wheatgrass. Big sagebrush dominated communities are also found in isolated areas in the South Castle in this ecosite.

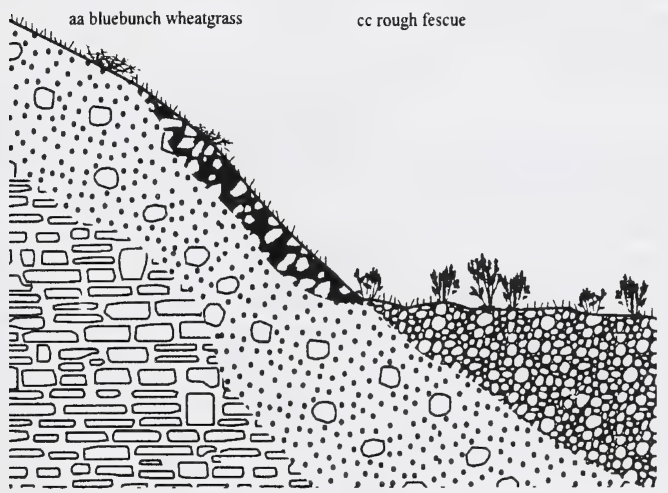

\section{SUCCESSIONAL RELATIONSHIPS}

Due to the nature of the site grasslands often remain the climax vegetation on these sites. On moister sites shrubs such as saskatoon, snowberry and chokecherry, often invade the site with succession to Douglas fir. Heavy grazing pressure on the grasslands can often lead to a degraded site that is dominated by fringed sage, sedge, and little clubmoss. However, on moister sites timothy and Kentucky bluegrass can often invade into this ecosite

\section{INDICATOR SPECIES}

Rose

Saskatoon

Bearberry

Little clubmoss

Sedge

Junegrass

Timothy
Chokecherry

Fringed sage

Northern wheatgrass

Sheep fescue

Bluebunch wheatgrass

Big sagebrush
Small lv'd everlasting

\section{subxeric/medium}

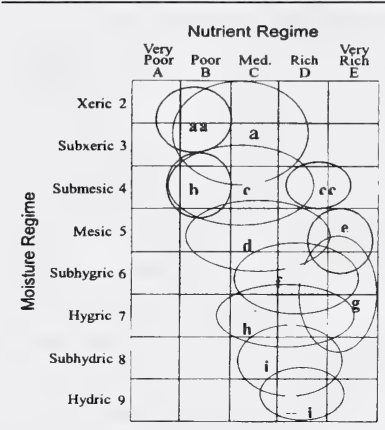

\section{SITE CHARACTERISTICS}

Moisture regime: xeric, subxeric, submesic

Nutrient regime: poor, medium

Topographic position: crest, upper, mid

Slope: $(16-30 \%)(31-45 \%)(45-70 \%)$

Aspect: south, southwest, west

\section{SOIL CHARACTERISTICS}

Organic thickness: $(0-2)$

Humus form: mull

Surface texture: CL,SiL

Effective texture: $\mathrm{CL}, \mathrm{SiC}$

Depth to Mottles/Gley: none

Drainage: rapid, well

Parent material: C,M

Soil subgroup: O.EB, O.R

\section{ECOSITE PHASES}

aal grassland $(n=42)$

aal a grazed grassland $(n=9)$

aa2 big sagebrush $(n=4)$ 


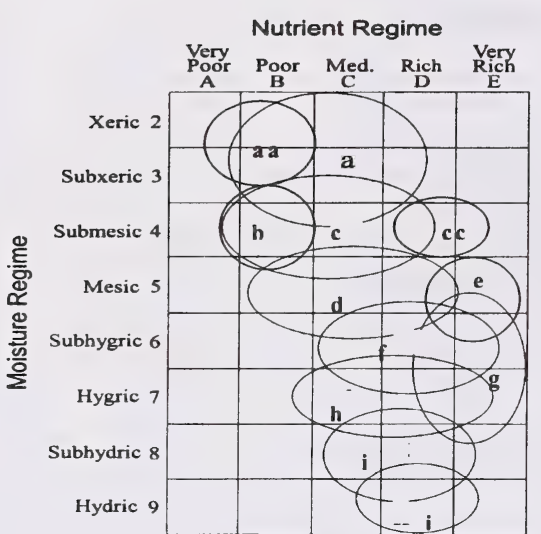

\section{CHARACTERISTIC SPECIES}

\section{Shrub}
[3] Saskatoon*
[3] Rose
[3] Snowberry
[1] Chokecherry
[2] Bearberry
[5] Fringed sage*
[1] Shrubby cinquefoil
[3] Juniper

Forb

\section{SITE CHARACTERISTICS}

Moisture regime: xeric, subxeric, submesic

Nutrient regime: poor, medium, rich

Topographic position: crest, upper slope, midslope Slope:(16-30\%) (31-45\%)(45-70\%)

Aspect: westerly, southerly

\section{SOIL CHARACTERISTICS}

Organic thickness: (0-2)

Humus form: mull

Surface texture: $\mathrm{CL}, \mathrm{SiL}$

Effective texture: $\mathrm{CL}, \mathrm{SiC}$

Depth to Mottles/Gley: none

Drainage: rapid, well

Parent material: C,M, E

Soil subgroup: O.R, O.EB

\section{RANGE PLANT COMMUNITY TYPES}
A1 Fringed sage/Junegrass $(n=11)$
A2 Northern wheatgrass-Sheep fescue $(n=2)$
A3 Small lv'd everlasting/Junegrass $(n=2)$
A4 Creeping juniper/Northern wheatgrass-Columbia needlegrass $(\mathrm{n}=2)$
A5 Little clubmoss/Richardson needlegrass $(n=1)$
B3 Bluebunch wheatgrass-Sedge $(\mathrm{n}=26)$

\section{Grasses}
[9] Sedge species
[1] Sheep fescue
[6] Bluebunch wheatgrass*
[1] Timothy
[13] Northern wheatgrass*
[8] Junegrass*
[2] Hairy wildrye
[2] Rough fescue
[1] Richardson needlegrass 


\section{aa1a Grazed grassland ( $\mathrm{n}=9$ )}

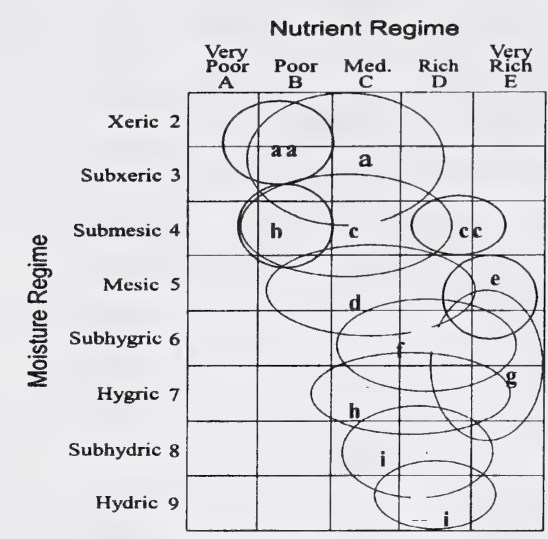

\section{SITE CHARACTERISTICS}

Moisture regime:, xeric, subxeric, submesic

Nutrient regime: poor, medium

Topographic position: crest, upper slope, midslope Slope: $(16-30 \%)(31-45 \%)(45-70 \%)$

Aspect: westerly, southrly

\section{SOIL CHARACTERISTICS}

Organic thickness: $(0-2)$

Humus form: mull

Surface texture: SiL, CL

Effective texture: $\mathrm{C}, \mathrm{SiC}$

Depth to Mottles/Gley: none

Drainage: rapid, well

Parent material: $\mathrm{C}, \mathrm{M}$

Soil subgroup: O.R, O.EB

\section{RANGE PLANT COMMUNITY TYPES}

A6 Kentucky bluegrass-Junegrass/Dandelion $(n=3)$

C6 Blunt sedge/Little clubmoss-Moss phlox $(n=5)$

C8 Northern wheatgrass-Kentucky bluegrass $(n=1)$ $\begin{array}{ll}\text { [1] } & \text { Shrubby cinquefoil } \\ {[1]} & \text { Creeping juniper } \\ {[4]} & \text { Snowberry } \\ {[2]} & \text { Rose } \\ {[2]} & \text { Fringed sage* } \\ {[1]} & \text { Bearberry }\end{array}$

Forb

[2] Showy locoweed

[1] Late yellow locoweed

[3] Small leaved everlasting

[2] Low goldenrod

[8] Little clubmoss*

[4] Moss phlox

[6] Dandelion*

\section{Grasses}

\section{[ 7 Junegrass}

[13] Northern wheatgrass

[ 7] Sedge

[15] Kentucky bluegrass*

[1] Rough fescue

[3] Parry oatgrass 


\section{aa2 big sagebrush $(n=4)$}

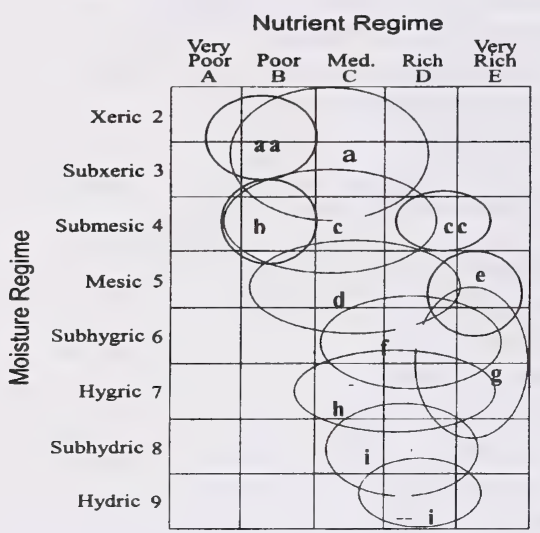

\section{CHARACTERISTIC SPECIES}

Shrub

[21] Big sagebrush*

[1] Snowberry

[1] Rose

[9] Saskatoon

[22] Bearberry*

Forb

[3] Yarrow

[2] Silky perennial lupine

[1] Small leaved everlasting

[1] Low goldenrod

[ 5] Little clubmoss*

[3] Wild bergamont

[2] Smooth aster

\section{Grasses}

[3] Junegrass

[5] Bluebunch wheatgrass*

[1] Sedge

[8] Idaho fescue

[1] Rough fescue

[4] California oatgrass

\section{SITE CHARACTERISTICS}

Moisture regime:, xeric, subxeric, submesic

Nutrient regime: poor, medium

Topographic position: crest, upper slope, midslope

Slope: $(16-30 \%)(31-45 \%)(45-70 \%)$

Aspect: westerly, southerly

\section{SOIL CHARACTERISTICS}

Organic thickness: (0-2)

Humus form: mull

Surface texture: $\mathrm{SiL}, \mathrm{CL}$

Effective texture: $\mathrm{C}, \mathrm{SiC}$

Depth to Mottles/Gley: none

Drainage: rapid, well

Parent material: C, M

Soil subgroup: O.R

\section{RANGE PLANT COMMUNITY TYPES}

B5 Big sagebrush/Bluebunch wheatgrass-Sedge $(n=4)$ 
b4 yellow mountain avens $(n=4)$

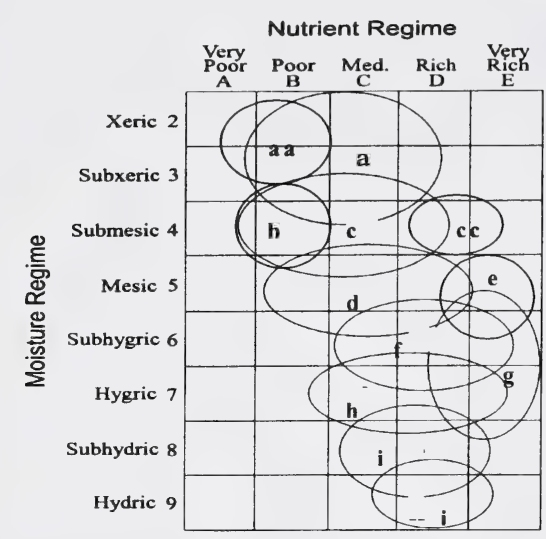

\section{CHARACTERISTIC SPECIES}

\section{Trees}

$\begin{array}{ll}\text { [ 7 ] } & \text { Balsam poplar* } \\ \text { [ 14 ] } & \text { White spruce }\end{array}$

Shrub

[24] Yellow mountain avens*

[2] Silverberry*

[1] Shrubby cinquefoil

[2] Buffaloberry

[1] Bearberry

Forb

[2] Yarrow

[2] Lindley's aster

[1] Cut leaved anemone

[1] Showy locoweed

Grasses

[7] Junegrass

[1] Sedge

[1] Canada bluegrass

\section{SITE CHARACTERISTICS}

Moisture regime: submesic, mesic

Nutrient regime: poor, medium

Topographic position: level

Slope: $(0-2 \%)$

Aspect: westerly, southerly

\section{SOIL CHARACTERISTICS}

Organic thickness: (0-2)

Humus form: no data

Surface texture: $S$

Effective texture: $S$

Depth to Mottles/Gley: none

Drainage: rapid, well

Parent material: F

Soil subgroup: O.R

\section{RANGE PLANT COMMUNITY TYPES}

D1 Yellow $\mathrm{mtn}$. avens-River alder/Low forb(n=1)

D2 Yellow $\mathrm{mtn}$. avens/Junegrass $(\mathrm{n}=2)$

F2 Sw-P1-Pb/Yellow mtn. avens $(n=1)$ 


\section{b5 bearberry grassland $(n=17)$}

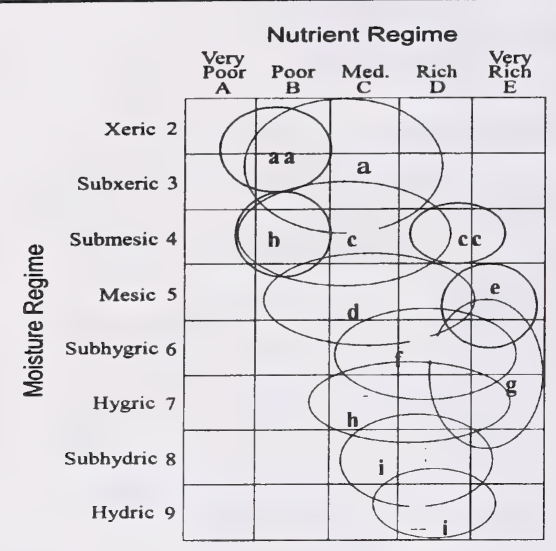

\section{CHARACTERISTIC SPECIES}

Shrub

[1] Juniper spp.

[3] Rose

[1] Shrubby cinquefoil

[2] Snowberry

[3] Saskatoon

[24 ] Bearberry*

Forb

[1] Yarrow

[1] Lindley's aster

[1] Cut leaved anemone

[1] Showy locoweed

[1] Small leaved everlasting*

[2] Strawberry

Grasses

[2] Junegrass

[2] Northern wheatgrass

[2] Rough fescue

[2] Hairy wildrye

\section{SITE CHARACTERISTICS}

Moisture regime: subxeric, submesic, mesic

Nutrient regime: poor, medium

Topographic position: crest, upper slope, midslope Slope:(0-2\%)(16-30\%) $(31-45 \%)(45-70 \%)$

Aspect: westerly, southerly

\section{SOIL CHARACTERISTICS}

Organic thickness: $(0-5)(6-15)$

Humus form: no data

Surface texture: $\mathrm{L}$

Effective texture: $\mathrm{L}$

Depth to Mottles/Gley: none

Drainage: rapid, well

Parent material: C, M

Soil subgroup: O.R, O.EB

RANGE PLANT COMMUNITY TYPES

\section{A7 Bearberry/Juniper $(n=17)$}




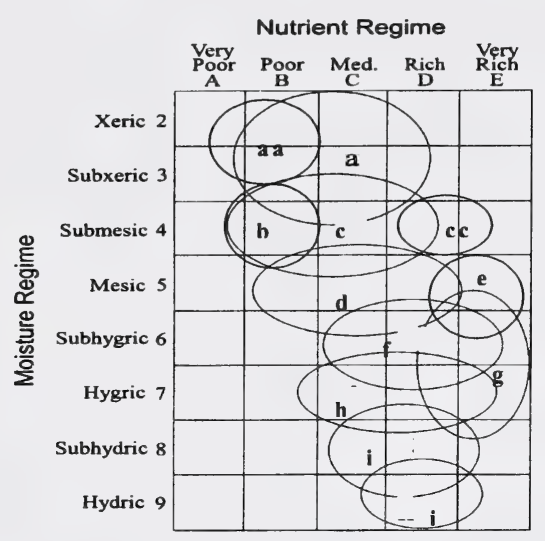

\section{CHARACTERISTIC SPECIES}

Trees

\section{[2] Limber pine}

Shrub

$\begin{array}{ll}{[2]} & \text { Saskatoon } \\ {[2]} & \text { Rose } \\ {[1]} & \text { Snowberry } \\ {[15]} & \text { Bearberry* } \\ {[1]} & \text { Fringed sage } \\ {[2]} & \text { Shrubby cinquefoil } \\ {[1]} & \text { Juniper }\end{array}$

Forb

\section{[2] Strawberry}

[2] Old mans whisker's

[3] Cut leaved anemone

[1] Woolly gromwell

[1] Yarrow

[2] Silky perennial lupine

[1] Little clubmoss

\section{[11] Parry oatgrass* \\ [2] Junegrass*}

\section{SITE CHARACTERISTICS}

Moisture regime: subxeric, submesic

Nutrient regime: medium, rich

Topographic position: crest, upper slope, midslope

Slope:(0-2\%) (16-30\%) (31-45\%)(45-70\%)

Aspect: westerly, southerly

\section{SOIL CHARACTERISTICS}

Organic thickness: $(0-2)(0-4)$

Humus form: mull

Surface texture: $\mathrm{SiL}, \mathrm{L}$

Effective texture: $\mathrm{CL}, \mathrm{SiCL}$

Depth to Mottles/Gley: none

Drainage: rapid, well

Parent material: C,M,T

Soil subgroup: O.MB

\section{RANGE PLANT COMMUNITY TYPES}

B2 Idaho fescue-Parry oatgrass-Rough fescue $(\mathrm{n}=52)$

B4 Rough fescue-Sedge/Bearberry $(n=48)$

E1 Pf/Rough fescue $(\mathrm{n}=1)$

I1 Foothills fescue-Western Porcupine grass $(n=10)$

\section{Grasses}

[3] Sedge species

[17] Rough fescue

[11] Idaho fescue*

[1] Slender wheatgrass 


\section{GENERAL DESCRIPTION}

This ecosite is typical of south and west facing slopes and lower slope positions throughout the Montane subregion from an elevation of $1300 \mathrm{~m}$ to $1900 \mathrm{~m}$. This ecosite is usually dominated by grass species because of the dry site conditions and westerly winds. The soils of this ecosite are dominated by deep black chernozemic soils. A number of rough fescue dominated sites have not had the species composition change in over 30 years of no disturbance indicating the climax nature of this ecosite in the Montane subregion.

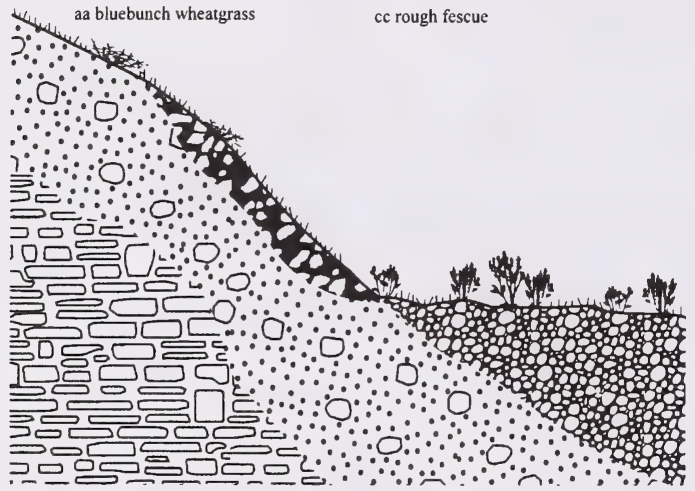

\section{SUCCESSIONAL RELATIONSHIPS}

Due to the nature of the site grasslands often remain the climax vegetation on these sites. On moister sites shrubs and trees such as saskatoon, snowberry, chokecherry and aspen often invade the site with succession to Douglas fir and Lodgepole pine. Heavy grazing pressure on these grasslands can often lead to a degraded site that is dominated by Kentucky bluegrass, timothy and clover species. Many sites within this ecosite have been cultivated and are dominated by cereal crops and smooth brome.

\section{INDICATOR SPECIES}

\begin{tabular}{ll}
\hline Shrubby cinquefoil & Bearberry \\
Old mans whisker's & Cut leaved anemone \\
Sticky purple geranium & Mountain shooting star \\
Woolly gromwell & Rough fescue \\
Junegrass & Idaho fescue
\end{tabular}

Parry oatgrass

Kentucky bluegrass

Slender wheatgrass Timothy

\section{submesic/rich}

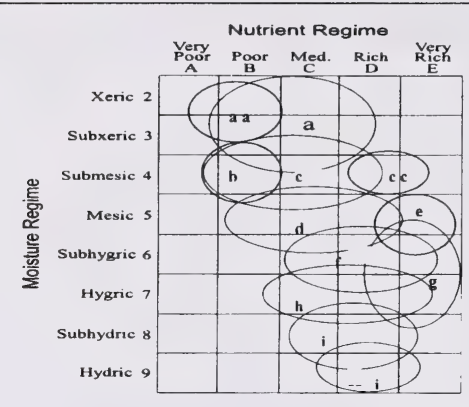

\section{SITE CHARACTERISTICS}

Moisture regime: submesic, mesic

Nutrient regime: rich, medium

Topographic position: crest, midslope, lower slope Slope: $(0-2 \%)^{5}(16-30 \%)^{3}(31-45 \%)^{1}(45-70 \%)^{1}$

Aspect: south, southwest, west

\section{SOIL CHARACTERISTICS}

Organic thickness: $(0-2)(2-5)$

Humus form: mull

Surface texture: CL, SiL, L

Effective texture: $\mathrm{CL}, \mathrm{SiL}, \mathrm{SL}$,

Depth to Mottles/Gley: none

Drainage: well

Parent material: F, GF, M

Soil subgroup: O.BL, O.DG, O.MB

\section{ECOSITE PHASES}

ccl rough fescue $(n=168)$

ccla grazed rough fescue $(n=262)$ 


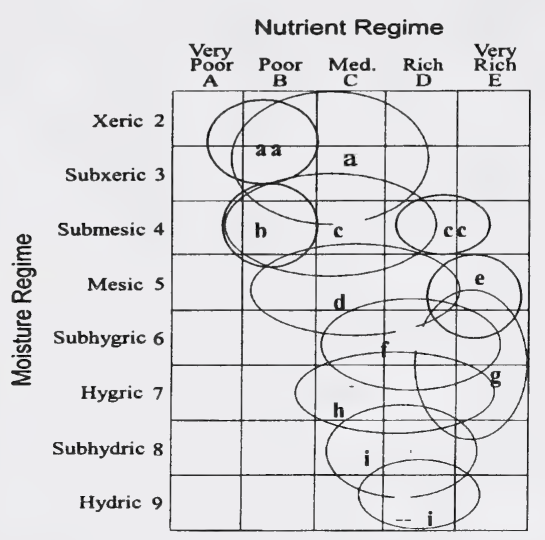

\section{CHARACTERISTIC SPECIES}

\section{Shrub}

\section{[3] Snowberry \\ [1] Saskatoon \\ [1] Rose \\ [3] Shrubby cinquefoil \\ [1] Juniper}

Forb

\section{[3] Strawberry}

[4] Old mans whisker's

[2] Cut leaved anemone

[1] Woolly gromwell

[2] Yarrow

[2] Silky perennial lupine

[3] Yellow beardtongue

[1] Shooting star

\section{[ 10 ] Parry oatgrass* \\ [2] Junegrass \\ [1] Fringed brome}

\section{SITE CHARACTERISTICS}

Moisture regime: submesic, mesic

Nutrient regime: medium, rich

Topographic position: level, midslope, lower slope Slope: $(0-2 \%)^{4}(16-30 \%)^{3}(31-45 \%)^{1}(45-70 \%)^{1}$

Aspect: westerly, southerly

\section{SOIL CHARACTERISTICS}

Organic thickness: $(0-2)(0-4)$

Humus form: mull

Surface texture: SiL, L, CL

Effective texture: $\mathrm{CL}, \mathrm{SiL}, \mathrm{SL}$

Depth to Mottles/Gley: none

Drainage: rapid, well

Parent material: F, GF, M

Soil subgroup: O.MB, O.BL, O.DG

\section{RANGE PLANT COMMUNITY TYPES}

A8 Prickly rose-Snowberry $(\mathrm{n}=6)$

A11 Rough fescue-Fringed brome-Sedge $(n=5)$

A12 Rough fescue-Sedge-Junegrass $(n=2)$

B1 Rough fescue-Idaho fescue-Parry oatgrass

$(\mathrm{n}=102)$

B8 Fd/I.fescue-Rough fescue ( $\mathrm{n}=5)$

B9 $\mathrm{Fd} /$ Idaho fescue-Sandberg bluegrass $(\mathrm{n}=1)$

B10 Aw/Strawberry/Rough fescue $(n=2)$

B15 Rough fescue-Hairy wildrye $(n=2)$

I2 Shrubby cinquefoil/Foothills rough fescueIntermediate oatgrass $(n=37)$

I4 Shrubby cinquefoil/Foothills rough fescueIdaho fescue $(\mathrm{n}=6)$

Grasses
[5] Sedge species
[29] Rough fescue*
[9] Idaho fescue*
[2] Slender wheatgrass 


\section{cc1a grazed rough fescue $(n=262)$}

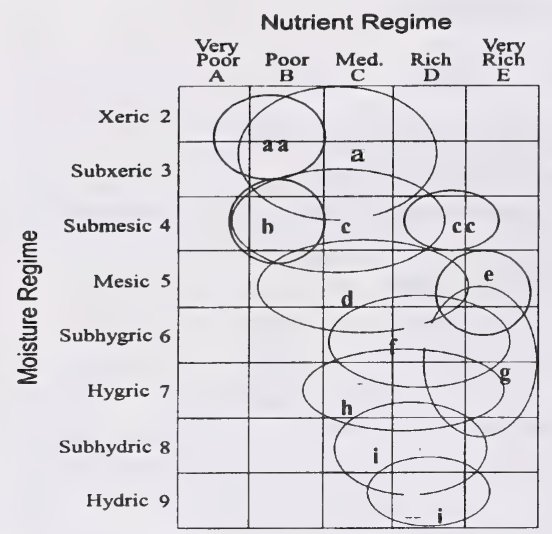

\section{CHARACTERISTIC SPECIES}

Shrub

[1] Rose

[3] Shrubby cinquefoil

Forb

[2] Strawberry

[ 10 ] Old mans whisker's

[2] Cut leaved anemone

[5] Yarrow

[ 10] Dandelion

[3] Yellow beardtongue

[3] Shooting star

[5] Graceful cinquefoil

\section{Grasses}

$\begin{array}{ll}{[5]} & \text { Sedge species } \\ {[12]} & \text { Rough fescue* } \\ {[15]} & \text { Idaho fescue* } \\ {[20]} & \text { Kentucky bluegrass* } \\ {[10]} & \text { Parry oatgrass* } \\ {[12]} & \text { Timothy* } \\ {[2]} & \text { Canada bluegrass }\end{array}$

\section{SITE CHARACTERISTICS}

Moisture regime: submesic, mesic

Nutrient regime: medium, rich

Topographic position: level, midslope, lower slope Slope: $(0-2 \%)^{4}(16-30 \%)^{3}(31-45 \%)^{1}(45-70 \%)^{1}$

Aspect: westerly, southerly

\section{SOIL CHARACTERISTICS}

Organic thickness: $(0-2)(0-4)$

Humus form: mull

Surface texture: SiL, L, CL

Effective texture: CL, SiL, SL

Depth to Mottles/Gley: none

Drainage: rapid, well

Parent material: F, GF, M

Soil subgroup: O.MB, O.BL, O.DG

\section{RANGE PLANT COMMUNITY TYPES}

\footnotetext{
A13 Sedge-Junegrass $(\mathrm{n}=2)$

C1 Idaho fescue-Parry oatgrass-Sedge $(n=32)$

C2 Canada bluegrass-Rough fescue $(n=14)$

C3 Kentucky bluegrass-Rough fescue $(n=70)$

C4 Kentucky bluegrass-Timothy/Dandelion $(n=74)$

C5 Smooth brome-Kentucky bluegrass $(n=14)$

C7 Creeping red fescue/Dandelion-Clover $(n=10)$

C9 Rough fescue-Kentucky bluegrass $(n=28)$

C10 Rough fescue-Sedge-Mountain brome $(n=2)$

I3 Shrubby cinquefoil/Foothills rough fescue-

Golden bean $(n=17)$
} 


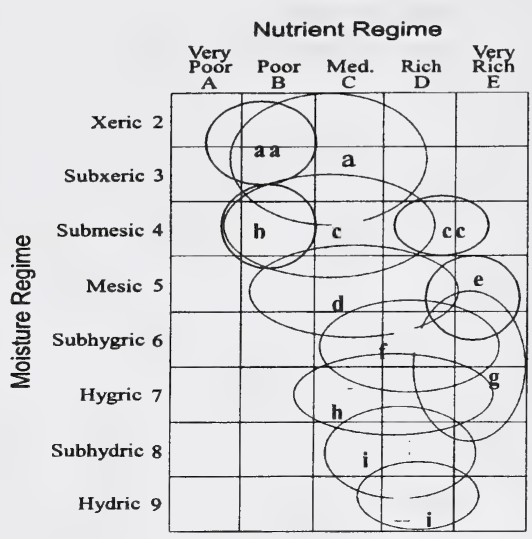

\section{CHARACTERISTIC SPECIES}

\section{Shrub}

[2] Willow spp.

Forb

[2] Fireweed

[1] Tall larkspur

Grasses

[6] Sedge species

[2] Kentucky bluegrass*

[18 ] Creeping red fescue*

[10] Hairy wildrye

[8] Timothy*
Moisture regime: submesic, mesic

Nutrient regime: medium, poor

Topographic position: midslope, upper slope Slope: ${ }^{3}(31-45 \%)(45-70 \%)$

Aspect: variable

\section{SOIL CHARACTERISTICS}

Organic thickness: $(0-5-2)(2-5))$

Humus form: mor

Surface texture: SiL, L, CL

Effective texture: L, SiL

Depth to Mottles/Gley: none

Drainage: well

Parent material: F, M

Soil subgroup: $\mathrm{O} . \mathrm{EB}$

\section{RANGE PLANT COMMUNITY TYPES}

A14 Creeping red fescue-Timothy $(\mathrm{n}=2)$ 
white meadowsweet Aw (n=47)

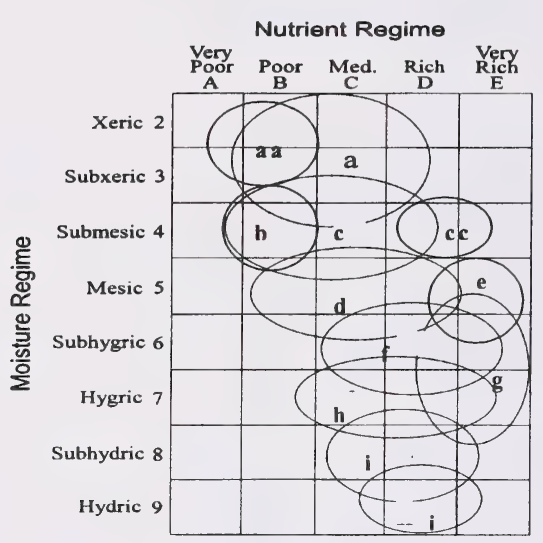

CHARACTERISTIC SPECIES

Trees

[47] Aspen

[2] Lodgepole pine

Shrub

[9] White meadowsweet

[6] Rose

Forb

[6] Showy aster

[8] Strawberry

[5] Yellow peavine

[2] Northern bedstraw

[4] Lindley's aster

\section{Grasses}

[19] Pinegrass

[1] Sedge

[ 5] Hairy wildrye

\section{SITE CHARACTERISTICS}

Moisture regime: mesic

Nutrient regime: medium, poor, rich

Topographic position: midslope, lower slope Slope: $(0-5 \%)(10-25 \%)$

Aspect: variable

\section{SOIL CHARACTERISTICS}

Organic thickness: $(6-15)(0-5)$

Humus form: mor

Surface texture: SiL, L, SL

Effective texture: L, SCL, SiCL, SL, SiL

Depth to Mottles/Gley: none (26-50)

Drainage: well, mod. well

Parent material: $X, M, G F$

Soil subgroup: O.EB, E.EB, O.GL

\section{RANGE PLANT COMMUNITY TYPES}

G4 Aw/White meadowsweet/Pinegrass ( $\mathrm{n}=12)$

G5 Aw/Rose/Pinegrass $(n=35)$ 
grazed Aw (n=6)

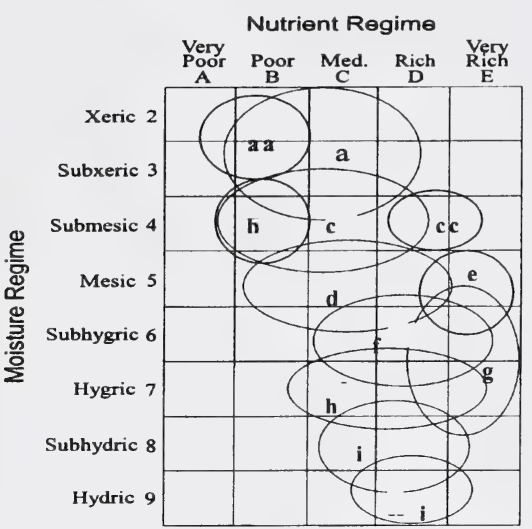

\section{CHARACTERISTIC SPECIES}

Trees

\section{[21] Aspen}

Shrub
[8] Wild red raspberry
[8] Rose

Forb
[6] Smooth aster
[7] Strawberry
[6] Yellow peavine
[10] Wild white geranium
[3] Dandelion

\section{Grasses}
[22] Pinegrass
[23] Kentucky bluegrass
[3] Hairy wildrye
[10] Orchardgrass

\section{SITE CHARACTERISTICS}

Moisture regime: mesic

Nutrient regime: medium

Topographic position: lower slope

Slope: (3-23\%)

Aspect: southerly

\section{SOIL CHARACTERISTICS}

Organic thickness: $(6-15)(0-5)$

Humus form: mor

Surface texture: SiL, L, SL

Effective texture: L, SCL, SiCL, SL, SiL

Depth to Mottles/Gley: none (26-50)

Drainage: well, mod. well

Parent material: $\mathrm{X}, \mathrm{M}, \mathrm{GF}$

Soil subgroup: O.EB, E.EB, O.GL

\section{RANGE PLANT COMMUNITY TYPES}

G6 Aw/Pinegrass-Kentucky bluegrass(n=4)

C12 Aw/Orchardgrass-Kentucky bluegrass $(n=2)$ 


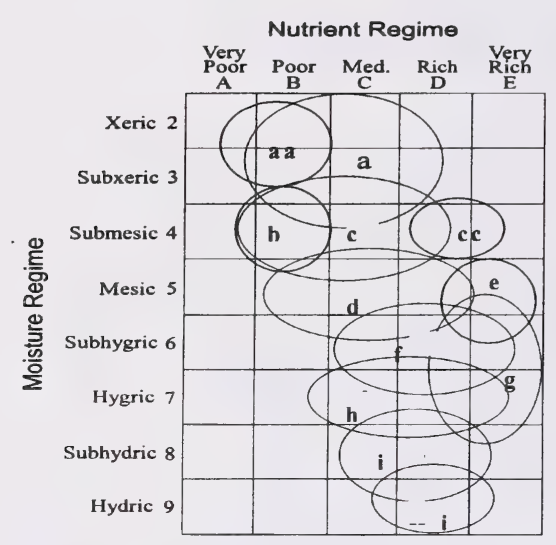

\section{CHARACTERISTIC SPECIES}

Shrub

[30] Bog birch

[7] Shrubby cinquefoil

Forb

\section{[3] Yarrow}

[2] Small leaved everlasting

[4] Cut leaved anemone

[4] Heart leaved Alexander

[3] Old mans whisker's

[3] American vetch

\section{Grasses}
[12] Sedge
[2] Rough fescue
[4] Sheep fescue
[3] Junegrass

\section{SITE CHARACTERISTICS}

Moisture regime: mesic

Nutrient regime: medium

Topographic position: lowerslope

Slope: (0-2)

Aspect: southerly

\section{SOIL CHARACTERISTICS}

Organic thickness: $(0-5)(2-5)$

Humus form: mull

Surface texture: SiL, L, CL

Effective texture: L, SiL

Depth to Mottles/Gley: none

Drainage: well

Parent maierial: $\mathrm{F}$,

Soil subgroup: O.EB

\section{RANGE PLANT COMMUNITY TYPES}

A10 Bog birch/Sedge-Rough fescue ( $\mathrm{n}=1)$

B6 Snowberry-Rose-Saskatoon/Bearberry $(\mathrm{n}=58)$ 
d5a grazed shrubland $(n=24)$

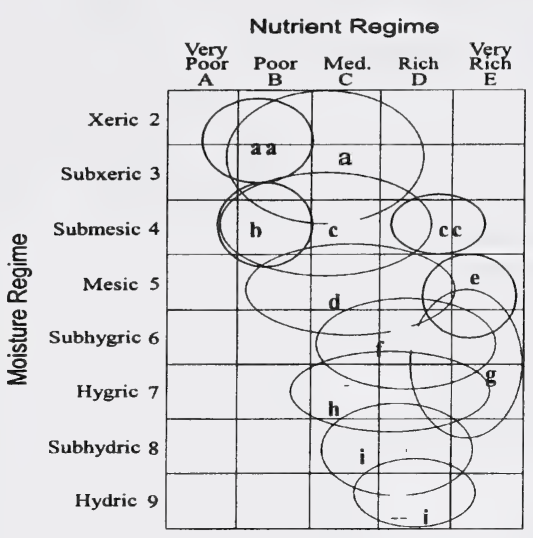

\section{CHARACTERISTIC SPECIES}

Shrub

[19] Big sagebrush

[18] Snowberry

[7] Buckthorn

Forb

[6] Strawberry

[20] Yellow beardstongue

[5] Yarrow

[3] Dandelion

[2] Star flowered solomon's seal

[1] American vetch

\section{Grasses}

\section{[1] Sedge species}

[25] Kentucky bluegrass*

[6] Timothy*

\section{SITE CHARACTERISTICS}

Moisture regime: mesic, subhygric

Nutrient regime: medium, rich

Topographic position: level, lower slope

Slope:(1-10\%)

Aspect: westerly, southerly

\section{SOIL CHARACTERISTICS}

Organic thickness: $(0-2)(0-4)$

Humus form: mull

Surface texture: SiL, L, CL

Effective texture: $\mathrm{CL}, \mathrm{SiL}, \mathrm{SL}$

Depth to Mottles/Gley: none

Drainage: rapid, well

Parent material: F, GF, M

Soil subgroup: O.MB, O.BL, O.DG

\section{RANGE PLANT COMMUNITY TYPES}

B16 Big sagebruch-Buckthorn/Kentucky bluegrass $(\mathrm{n}=2)$

C11 Snowberry/Kentucky bluegrass $(n=3)$

I5 Snowberry/Kentucky bluegrass $(n=18)$

I6 Silverberry/Kentucky bluegrass $(n=1)$ 


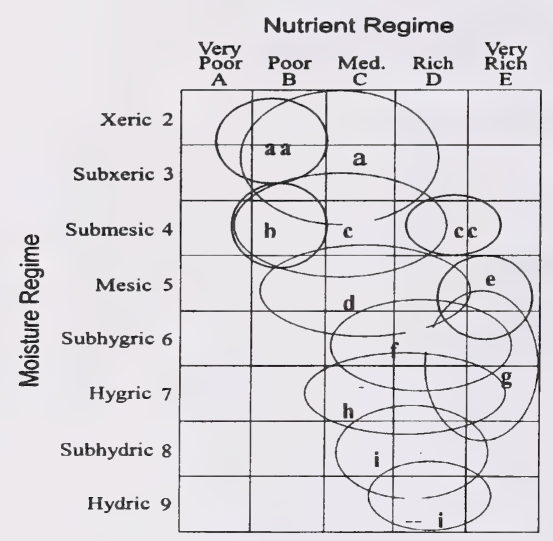

\section{CHARACTERISTIC SPECIES}

Shrub
[2] Snowberry
[2] Rose
[2] White meadowsweet

Forb
[13] Strawberry
[4] Yellow peavine
[5] Silky perennial lupine
[5] Showy aster

\section{Grasses}
[23] Pinegrass
[7] Hairy wildrye
[1] Northern awnless brome

Moisture regime: mesic, subhygric

Nutrient regime: medium, rich

Topographic position: level, mid slope, lower slope Slope:(0-46\%)

Aspect: northerly ${ }^{5}$, westerly ${ }^{4}$, southerly ${ }^{1}$

\section{SOIL CHARACTERISTICS}

Organic thickness: $(0-2)(0-4)$

Humus form: mull

Surface texture: SiL, L, CL

Effective texture: $\mathrm{CL}, \mathrm{SiL}, \mathrm{SL}$

Depth to Mottles/Gley: none

Drainage: rapid, well

Parent material: F, GF, M

Soil subgroup: O.EB, O.BL, O.DG

\section{RANGE PLANT COMMUNITY TYPES}

$\overline{\text { B7 Pinegrass-Hairy wildrye/Strawberry }(\mathrm{n}=11)}$ 


\section{e2a grazed aspen $(n=18)$}

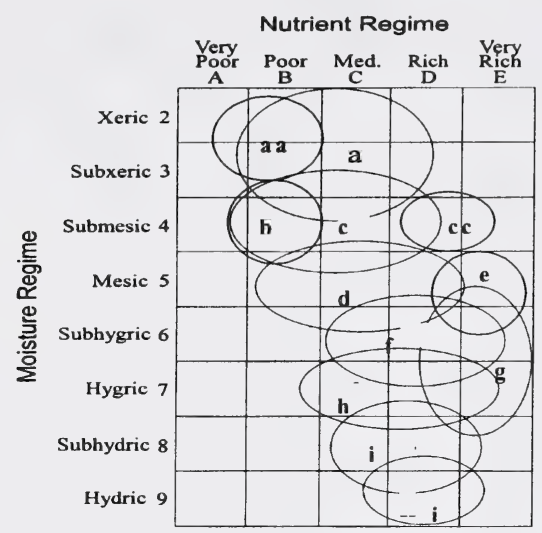

\section{CHARACTERISTIC SPECIES}

Trees

[60] Aspen

[9] Lodgepole pine

Shrub

[3] Rose

[30] Snowberry

[5] Thimbleberry

[2] Saskatoon

Forb

[8] Strawberry

[5] Clover

[ 5] Smooth aster

[20] Dandelion

[8] Wild white geranium

[2] American vetch

[2] Veiny meadow rue

\section{Grasses}
[2] Mountain brome
[20 ] Kentucky bluegrass*
[18] Timothy*
[4] Pinegrass

\section{SITE CHARACTERISTICS}

Moisture regime: mesic $^{9}$, submesic ${ }^{1}$

Nutrient regime: medium $^{8}$, rich $^{2}$

Topographic position: level, lower slope

Slope: $(0-4 \%)^{8}(20-26 \%)^{2}$

Aspect: westerly, southerly

\section{SOIL CHARACTERISTICS}

Organic thickness: (0-5)(6-15)

Humus form: mor

Surface texture: L, SL, CL

Effective texture: $\mathrm{CL}, \mathrm{SCL}, \mathrm{L}$

Depth to Mottles/Gley: none

Drainage: mod.well, well

Parent material: F, GF, M

Soil subgroup: O.EB, O.BL, CU.R, O.DG, O.MB

\section{RANGE PLANT COMMUNITY TYPES}

G7 Aw/Timothy-Kentucky bluegrass $(n=13)$

G9 Aw/Snowberry/Kentucky bluegrass ( $\mathrm{n}=2)$

F9 Pl-Aw/Snowberry/Kentucky bluegrass $(n=1)$

F10 Aw-Fa-Se/Timothy $(n=2)$ 


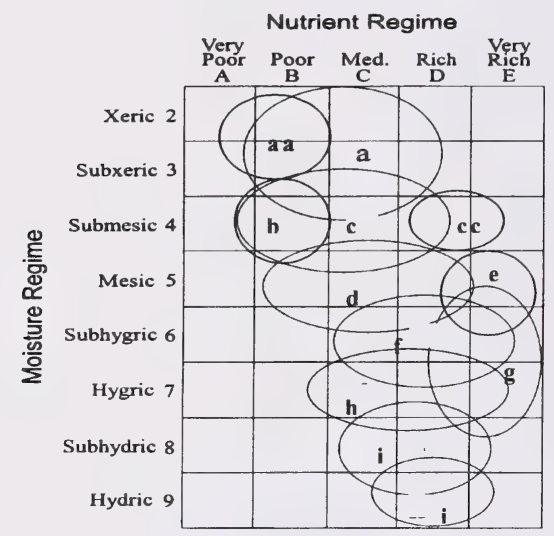

\section{CHARACTERISTIC SPECIES}

Shrub
[1] Rose
[8] Snowberry
[30] Thimbleberry
[5] Hawthorn

Forb
[8] Strawberry
[6] Lindleys aster
[4] Showy aster
[2] Fireweed
[2] Baneberry
[2] Yellow peavine
[8] Wild bergamont
[3] Star flowered solomon seal

\section{Grasses}
[2] Rough fescue
[1] Fringed brome
[3] Idaho fescue
[4] Pinegrass
[2] Parry oatgrass
[2] Slender wheatgrass

\section{SITE CHARACTERISTICS}

Moisture regime: mesic $^{5}$, subhygric ${ }^{5}$

Nutrient regime: medium $^{2}$, rich $^{8}$

Topographic position: level, lower slope, midslope Slope: $(0-4 \%)^{8}(20-26 \%)^{2}(35-47)$

Aspect: variable

\section{SOIL CHARACTERISTICS}

Organic thickness: (0-5)(6-15)

Humus form: mor, raw moder

Surface texture: $\mathrm{L}, \mathrm{SL}, \mathrm{CL}$

Effective texture: CL, SiCL, SC L

Depth to Mottles/Gley: none

Drainage: mod.well, well

Parent material: F, M

Soil subgroup: O.GL, O.EB, O.B

\section{RANGE PLANT COMMUNITY TYPES}

B11 Thimbleberry brush $(n=3)$

B13 Forb meadows $(n=2)$

D14 Hawthorn-Snowberry/Kentucky bluegrass $(n=2)$ 


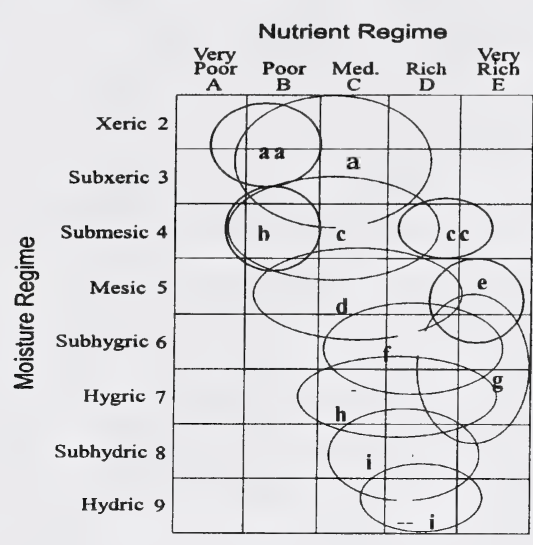

\section{CHARACTERISTIC SPECIES}

Trees

[ 75 ] Balsam poplar

Shrub

[5] Rose

[9] Sticky currant

Forb

[11]

[6]

Showy aster

Cow parsnip

Canada violet

Sweet cicely

Grasses

[11] Sedge

[10 ] Kentucky bluegrass*

\section{SITE CHARACTERISTICS}

Moisture regime: subhygric

Nutrient regime: rich

Topographic position: level, lower slope

Slope:(0-3\%)

Aspect: westerly, southerly

\section{SOIL CHARACTERISTICS}

Organic thickness: $(0-5)$

Humus form: moder

Surface texture: $\mathrm{L}$,

Effective texture: CL

Depth to Mottles/Gley: none

Drainage: mod.well,

Parent material: GF

Soil subgroup: not available

\section{RANGE PLANT COMMUNITY TYPES}

$\overline{\mathrm{G} 13 \mathrm{~Pb} / \text { Cow parsnip/Kentucky bluegrass }(\mathrm{n}=1)}$ $\mathrm{G} 14 \mathrm{~Pb} /$ Snowberry/Kentucky bluegrass $(\mathrm{n}=12)$ 
g meadow $(\mathrm{n}=22)$ (taken from Ecosites of West-Central Alberta)

\section{GENERAL DESCRIPTION}

The meadow ecosite tends to be mesic to subhygric and occurs on fluvial parent materials where flooding and/or high water tables increase soil water content and replenish nutrients. The soils on these sites tend to have thick Ah horizons and loamy textures.

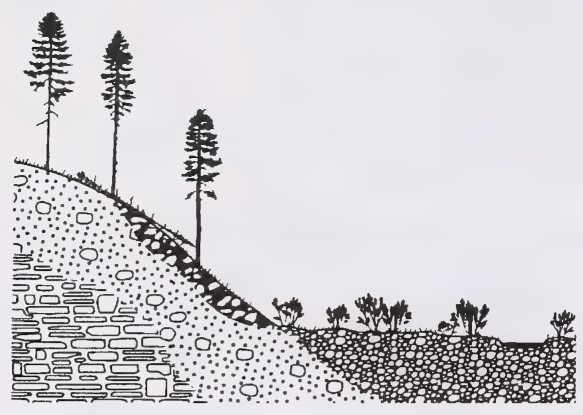

\section{SUCCESSIONAL RELATIONSHIPS}

The meadow ecosite is successional stable.

Disturbance regime, cold air drainage, and competition from a diverse cover of shrubs, forbs and grasses slow or inhibit the establishment of trees. If trees become established, the rich, moist loamy soils are conducive to rapid growth.

\section{INDICATOR SPECIES}

\section{Willow}

Veiny meadow rue

Tufted hairgrass

Slender wheatgrass
Cow parsnip

Avens

Marsh reedgrass

Sedge

\section{subhygric/very rich}

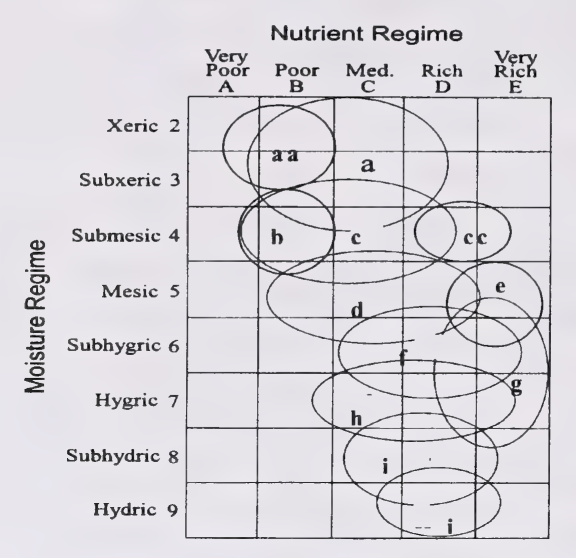

\section{SITE CHARACTERISTICS}

Moisture regime: subhydric, hygric,mesic

Nutrient regime: rich, very rich, medium

Topographic position: level, depression, toe

Slope: level, (2-5\%)

Aspect: level, southerly, easterly

\section{SOIL CHARACTERISTICS}

Organic thickness: (6-15)(0-5)

Humus form: mor, mull, raw moder

Surface texture: SiC, L, CL, SiL, SL, SCL

Effective texture: SiC, SiCL, SiL, SL, SCL, L

Depth to Mottles/Gley: (0-25),(51-100),none,(26-

50)

Drainage: imperfect, poor, mod. well, well

Parent material: $F$,

Soil subgroup:R.HG, O.R, GLCU.R, CU.HR

\section{ECOSITE PHASES}

g1 shrubby meadow $(\mathrm{n}=7)$

gla grazed shrubby meadow $(n=11)$

g2 grassy meadow $(\mathrm{n}=4)$ 


\section{g1 shrubby meadow $(n=7)$}

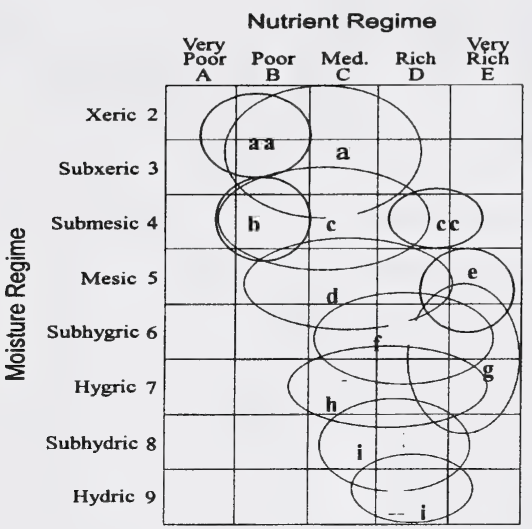

\section{CHARACTERISTIC SPECIES}

Shrub

[14] Green alder

[8] Bog birch

[27] Willow

[9] Raspberry

Forb

[1] Strawberry

[1] Fireweed

[5] Stinging nettle

[2] Marsh valerian

Grasses

[11] Sedge

[4] Hairy wildrye

[4] Tufted hairgrass

[4] Timothy

\section{SITE CHARACTERISTICS}

Moisture regime: mesic, subhygric

Nutrient regime: medium, rich

Topographic position: level, mid slope, lower slope

Slope:(0-5\%)

Aspect: variable

\section{SOIL CHARACTERISTICS}

Organic thickness: (6-15)(0-5)

Humus form: mor, mull, raw moder

Surface texture: SiC, L, CL, SiL, SL, SCL

Effective texture: $\mathrm{SiC}, \mathrm{SiCL}, \mathrm{SiL}, \mathrm{SL}, \mathrm{SCL}, \mathrm{L}$

Depth to Mottles/Gley: (0-25),(51-100),none,(26-

50)

Drainage: imperfect, poor, mod. well, well

Parent material: F,

Soil subgroup:R.HG, O.R, GLCU.R, CU.HR

\section{RANGE PLANT COMMUNITY TYPES}

D3 Bebb willow/Hairy wildrye $(n=2)$

D5 Green alder-Scoulers willow-Raspberry $(n=2)$

D10 Dwarf birch-Shrubby cinquefoil/Marsh valerian/Sedge $(\mathrm{n}=2)$

D13 Water birch-Smooth willow/Pinegrass $(n=1)$ 


\section{g1a grazed shrubby meadow $(\mathrm{n}=11)$}

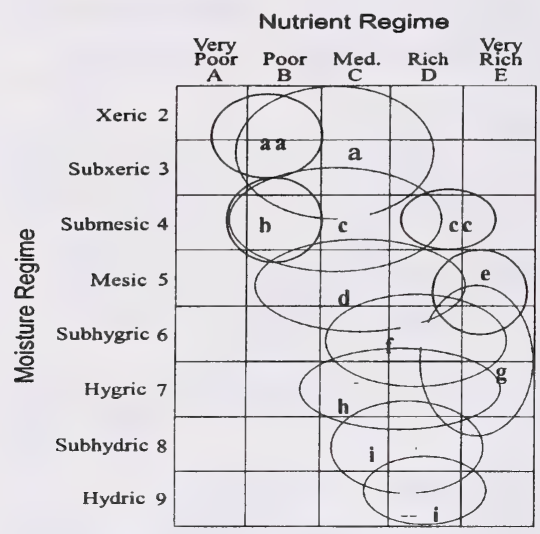

\section{CHARACTERISTIC SPECIES}

Shrub

[15] Flat leaved willow

[1] Bog birch

[25] Bebb willow

Forb

[3] Marsh violet

[2] Rush aster

\section{Grasses}

[6] Sedge

[27 ] Kentucky bluegrass

[18] Quackgrass

[4] Alpine rush

\section{SITE CHARACTERISTICS}

Moisture regime: mesic, hygric

Nutrient regime: medium, rich

Topographic position: level, mid slope, lower slope Slope:(0-2\%)

Aspect: variable

\section{SOIL CHARACTERISTICS}

Organic thickness: $(6-15)(0-5)$

Humus form: mor, mull, raw moder

Surface texture: $\mathrm{SiC}, \mathrm{L}, \mathrm{CL}$,

Effective texture: $\mathrm{SiC}, \mathrm{SiCL}$,

Depth to Mottles/Gley: not available

Drainage: poor, well

Parent material: F,

Soil subgroup:R.HG, O.R,

\section{RANGE PLANT COMMUNITY TYPES}

D4 Bebb willow/Kentucky bluegrass $(\mathrm{n}=9)$ D6 Flat leaved willow/Quackgrass-Kentucky bluegrass $(n=2)$ 


\section{g2 grassy meadow $(\mathrm{n}=4)$}

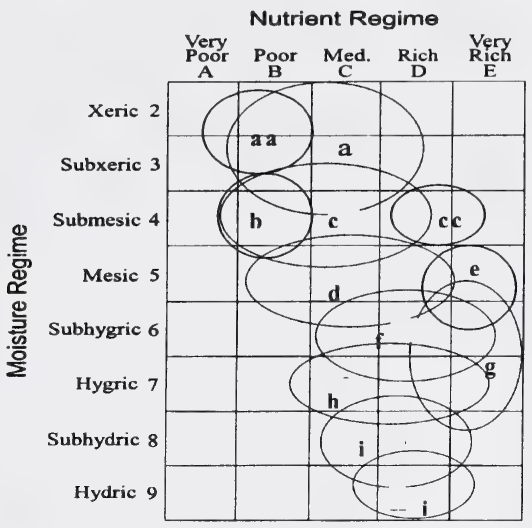

\section{CHARACTERISTIC SPECIES}

Shrub

[10] Shrubby cinquefoil

Forb

[10] Old mans whisker's

[4] Veiny meadow

[12] Graceful cinquefoil

[2] Yellow beardstongue

\section{Grasses}
[25] Sedge
[2] Hairy wildrye
[20] Tufted hairgrass
[6] Slender wheatgrass
[12] Baltic rush

\section{SITE CHARACTERISTICS}

Moisture regime: hygric, subhygric

Nutrient regime: rich

Topographic position: level, lower slope

Slope:(0-5\%)

Aspect: variable

\section{SOIL CHARACTERISTICS}

Organic thickness: (6-15)(0-5)

Humus form: mor, mull, raw moder

Surface texture: SiC, L, CL, SiL, SL, SCL

Effective texture: SiC, SiCL, SiL, SL, SCL, L

Depth to Mottles/Gley: (0-25),(51-100),none,(26-

50)

Drainage: imperfect, poor, mod. well, well

Parent material: F,

Soil subgroup:R.HG, O.R, GLCU.R, CU.HR

\section{RANGE PLANT COMMUNITY TYPES}

A9 Tufted hairgrass-Sedge( $\mathrm{n}=1)$

B13 Tufted hairgrass-Baltic rush ( $\mathrm{n}=2$ )

B13a Baltic rush $(n=1)$ 
h horsetail $(\mathrm{n}=12)$ (taken from Ecosites of West-Central Alberta)

\section{GENERAL DESCRIPTION}

The horsetail ecosite is wet and nutrient rich. These sites are commonly found on toe and lower slope positions with fluvial parent materials where flooding or seepage periodically replenishes the substrate nutrient availability. With wet soils gleysolic soils are common and organic matter tends to accumulate. Mottles were within $25 \mathrm{~cm}$ of the soil surface in over $80 \%$ of the sites. Horsetails commonly form a blanket over the forest floor.

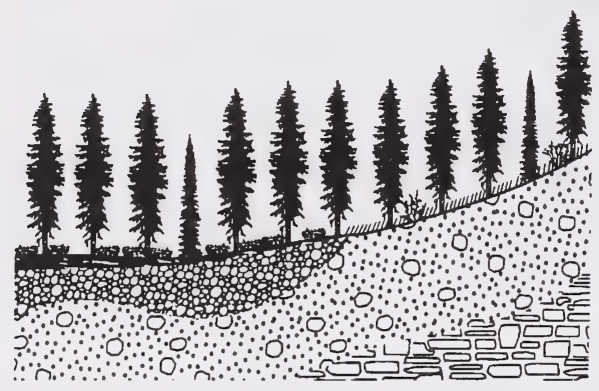

\section{SUCCESSIONAL RELATIONSHIPS}

Balsam poplar is a pioneer species on this ecosite. White spruce is the expected climax species, however its establishment may be slow due to high vegetation cover.

\section{INDICATOR SPECIES}

\section{Meadow horsetail}

Common horsetail

White spruce

Black spruce

Balsam poplar

Aspen

Willow

\section{hygric/rich}

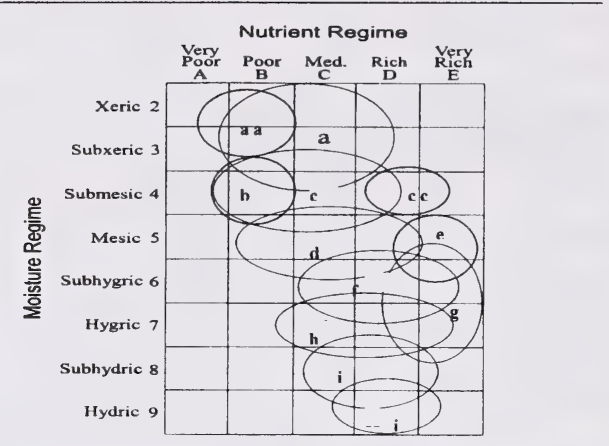

\section{SITE CHARACTERISTICS}

Moisture regime: subhygric, hygric

Nutrient regime: rich, very rich

Topographic position: level, depression, toe Slope: level, (0-1\%)

Aspect: level, southerly, easterly

\section{SOIL CHARACTERISTICS}

Organic thickness: (26-39)(60-79)(16-25))

Humus form: moder, peaty mor

Surface texture: mesic, $\mathrm{SiL}, \mathrm{SiC}, \mathrm{Si}$

Effective texture: humic, $\mathrm{SiL}, \mathrm{SiC}, \mathrm{Si}$

Depth to Mottles/Gley: (0-25)

Drainage: imperfect, poor, mod. well, well

Parent material: F, FL, E

Soil subgroup:R.HG, O.R, GLCU.R, GL.R

\section{ECOSITE PHASES}

h2 horsetail Sw $(n=6)$

h3 horsetail shrubland $(n=6)$ 


\section{h2} horsetail Sw $(n=6)$

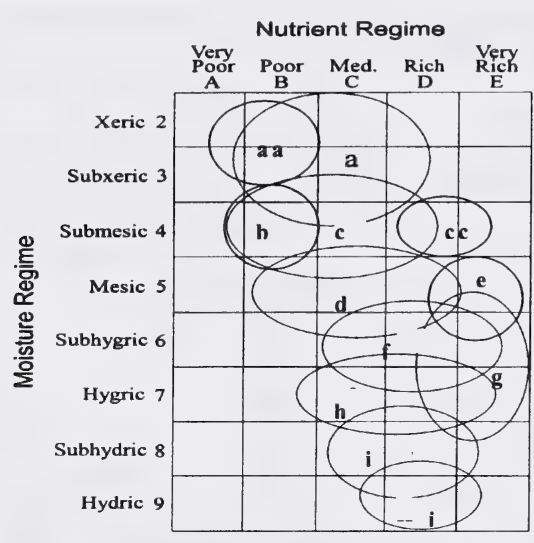

\section{CHARACTERISTIC SPECIES}

\section{Trees}

$\begin{array}{ll}{[60]} & \text { White spruce } \\ {[15]} & \text { Aspen } \\ {[10]} & \text { Balsam poplar }\end{array}$

Shrub

[3] Rose

[5] Silverberry

Forb

[4] Dandelion

[5] Dwarf scouring rush

[20] Horsetail

[4] Lindley's aster

[1] American vetch

\section{Grasses}

[ 7] Kentucky bluegrass

[5] Hairy wildrye

\section{SITE CHARACTERISTICS}

Moisture regime: subhygric

Nutrient regime: rich

Topographic position: level

Slope: level

Aspect: variable

\section{SOIL CHARACTERISTICS}

Organic thickness: (26-39)(60-79)(16-25))

Humus form: moder, peaty mor

Surface texture: mesic, SiL, SiC, $\mathrm{Si}$

Effective texture: humic, $\mathrm{SiL}, \mathrm{SiC}, \mathrm{Si}$

Depth to Mottles/Gley: (0-25)

Drainage: imperfect, poor, mod. well, well

Parent material: F, FL, E

Soil subgroup:R.HG, O.R, GLCU.R, GL.R

\section{RANGE PLANT COMMUNITY TYPES}

F12 Sw-Aw/Scouring rush $(n=1)$

E12a Sw/Horsetail $(n=4)$

E12b Sw/Silverberry/Horsetail $(n=1)$ 


\section{h3 horsetail shrubland $(\mathrm{n}=6)$}

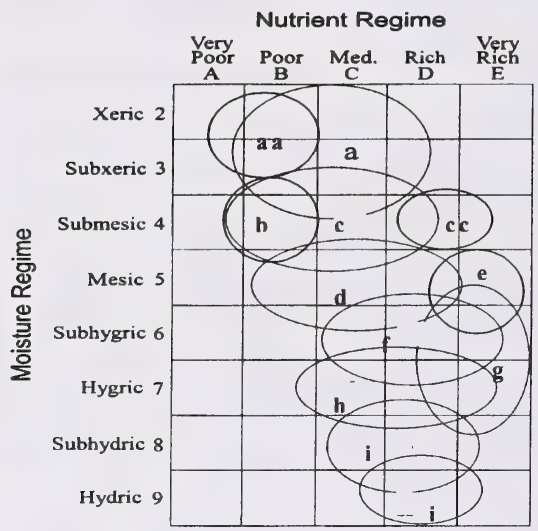

\section{CHARACTERISTIC SPECIES}

Shrub

[40] Willow

[1] Red osier dogwood

[1] Rose

Forb

[ 40 ] Field horsetail

[1] Sweet scented bedstraw

[1] Tall lungwort

[1] Dandelion

\section{SITE CHARACTERISTICS}

Moisture regime: hygric

Nutrient regime: rich

Topographic position: level

Slope: level

Aspect: variable

\section{SOIL CHARACTERISTICS}

Organic thickness: $(26-39)(60-79)(16-25))$

Humus form: moder, peaty mor

Surface texture: mesic, SiL, $\mathrm{SiC}, \mathrm{Si}$

Effective texture: humic, $\mathrm{SiL}, \mathrm{SiC}, \mathrm{Si}$

Depth to Mottles/Gley: (0-25)

Drainage: imperfect, poor, mod. well, well

Parent material: F, FL, E

Soil subgroup:R.HG, O.R, GLCU.R, GL.R

\section{RANGE PLANT COMMUNITY TYPES}

D7 Flat lv'd willow/Horsetail/Sedge $(n=6)$ 
ij fen $(n=40)$ (taken from Ecosites of WestCentral Alberta)

\section{GENERAL DESCRIPTION}

The rich and poor fen are combined in this ecosite. The fen ecosite is generally characterized by flowing oxygenated water and alkaline, nutrient-rich conditions. This ecosite occupies level, depressional and lower slope positions where impeded drainage or high water tables enhance the accumulation of organic matter consisting of sedges, golden moss, tufted moss, and brown moss. Black spruce, white spruce, and/or tamarack dominate the sparse canopy on the treed phase. Dwarf birch or willow form the canopy of the shrubby phase and sedges dominate the graminoid phase of this ecosite.

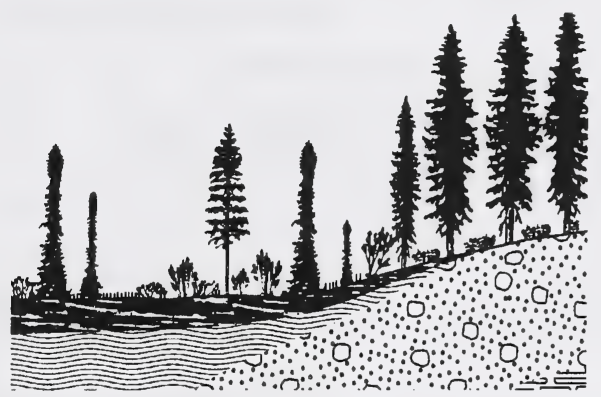

\section{SUCCESSIONAL RELATIONSHIPS}

Black spruce or white spruce are the edaphic climax trees on this ecosite. On calcareous materials black spruce may be replaced by white spruce as the climax tree species. Species composition and direction of succession changes with changing hydrologic regime. As with other wetlands, fens have slow successional rates so recovery from disturbance may also be slow.

\section{INDICATOR SPECIES}

\section{Black spruce}

tamarack

Willow

Labrador tea

Dwarf birch

Horsetail
Sedge

Golden moss

Brown moss

Tufted moss

\section{subhydric/rich}

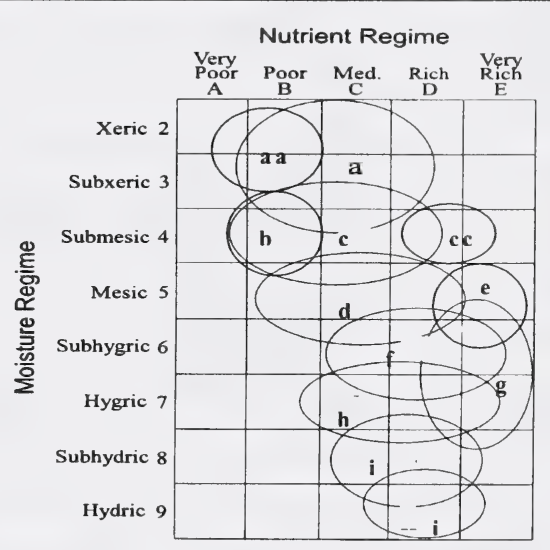

\section{SITE CHARACTERISTICS}

Moisture regime: subhygric, hygric, subhydric,hydric Nutrient regime: rich, very rich, medium

Topographic position: level, depression, toe

Slope: level, $(0-1 \%)$

Aspect: level, southerly, easterly

\section{SOIL CHARACTERISTICS}

Organic thickness: $(>80)(60-79)$

Humus form: mor, peaty mor

Surface texture: fibric, mesic

Effective texture: fibric, mesic

Depth to Mottles/Gley: not applicable

Drainage: imperfect, poor, very poor

Parent material: $O$

Soil subgroup:R.G, TY.M, TY.F, T.M, T.F, R.HG, O.HG, O.G, FI.M

\section{ECOSITE PHASES}

ij treed fen $(n=4)$

ij shrubby fen $(n=20)$

ij graminoid fen $(n=16)$ 


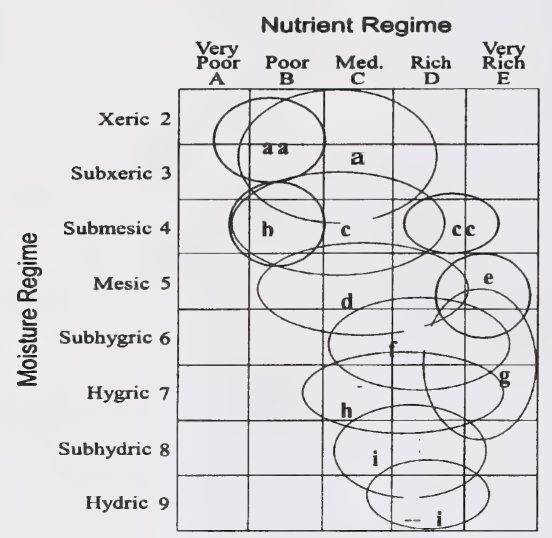

\section{CHARACTERISTIC SPECIES}

Moisture regime: subhygric, subhydric

Nutrient regime: rich, poor, medium

Topographic position: level, depression

Slope: level

Aspect: variable

\section{SOIL CHARACTERISTICS}

Organic thickness: $(>80)(60-79)$

Humus form: mor, peaty mor

Surface texture: fibric, mesic

Effective texture: fibric, mesic

Depth to Mottles/Gley: not applicable

Drainage: imperfect, poor, very poor

Parent material: $O$

Soil subgroup:R.G, TY.M, TY.F, T.M, T.F, R.HG, O.HG, O.G, FI.M

\section{RANGE PLANT COMMUNITY TYPES}

D12 Sb/Willow/Wire rush-Sedge/Moss ( $n=3$ )

E17 Sb-Lt/Labrador tea(n=1)

[25] Black spruce

[20] White spruce

[5] Larch

Shrub

[20] Willow

[6] Labrador tea

[2] Dwarf birch

Forb

[1] Field horsetail

[1] Sweet scented bedstraw

[3] Scouring rush

[1] Dandelion

Grass

[20] Sedge

[1] Hairy wildrye

[7] Wire rush

Moss

[10] Golden moss 
ij2 shrubby fen $(n=20)$

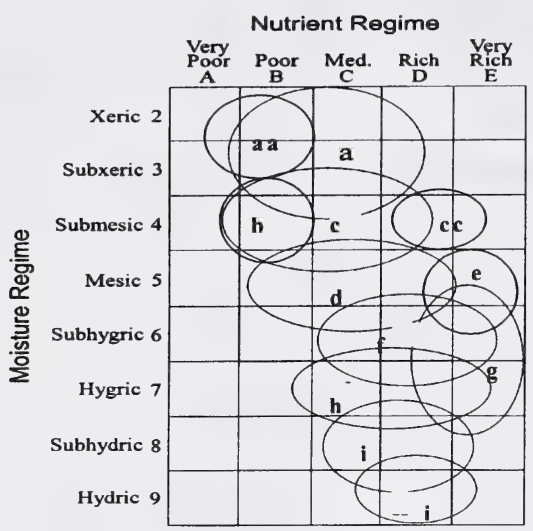

CHARACTERISTIC SPECIES

Trees

[2] Aspen

Shrub

[20] Willow

[4] Shrubby cinquefoil

[14] Dwarf birch

Forb

[2] Lindley's aster

[2] Strawberry

[1] Arrow leaved coltsfoot

[1] Fireweed

Grass

[22] Sedge

[2] Tufted hairgrass

[5] Wire rush

[2] Marsh reedgrass

Moss

[4] Golden moss

\section{SITE CHARACTERISTICS}

Moisture regime: subhygric, subhydric Nutrient regime: very rich, rich medium Topographic position: level, depression Slope: level, (0-2\%)

Aspect: variable

\section{SOIL CHARACTERISTICS}

Organic thickness: $(>80)(60-79)$

Humus form: mor, peaty mor

Surface texture: fibric, mesic

Effective texture: fibric, mesic

Depth to Mottles/Gley: not applicable

Drainage: imperfect, poor, very poor

Parent material: O

Soil subgroup:R.G, TY.M, TY.F, T.M, T.F, R.HG, O.HG, O.G, FI.M

\section{RANGE PLANT COMMUNITY TYPES}

D2a Drummond's willow $(\mathrm{n}=1)$

D3a Bebb willow/Marsh reedgrass $(n=1)$

D8 Myrtle lv'd willow/Sedge $(\mathrm{n}=12)$

D9 Basket willow/Sedge $(n=3)$

D9a Basket willow/Kentucky bluegrass $(\mathrm{n}=1)$

D11 Sw/Willow/Water sedge/Golden moss $(\mathrm{n}=2)$ 


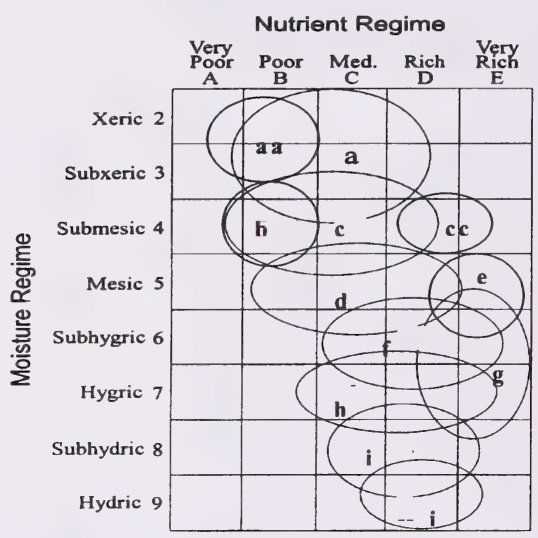

\section{CHARACTERISTIC SPECIES}

\section{Shrub}

[1] Willow

Forb

[ 5] Purple avens

[3] Smooth aster

[4] Swamp horsetail

[1] Fireweed

\section{Grass}

[43 ] Sedge

[7] Fowl bluegrass

[9] Wire rush

[6] Marsh reedgrass

[10 ] Cattail

[2] Great bulrush

\section{SITE CHARACTERISTICS}

Moisture regime: hygric, subhydric Nutrient regime: very rich, rich Topographic position: level, depression Slope: level, $(0-2 \%)$

Aspect: variable

\section{SOIL CHARACTERISTICS}

Organic thickness: $(>80)(60-79)$

Humus form: mor, peaty mor Surface texture: fibric, mesic Effective texture: fibric, mesic Depth to Mottles/Gley: not applicable Drainage: ir.uperfect, poor Parent material: O

Soil subgroup:R.G, TY.M, TY.F, T.M, T.F, R.HG, O.HG, O.G, FI.M

\section{RANGE PLANT COMMUNITY TYPES}

B12 Beaked-Water Sedge $(n=8)$

B12a Awned Sedge

B17 Creeping spike rush $(n=1)$

B18 Small fruited bulrush $(n=1)$

B19 Great bulrush $(n=1)$

B20 Cattail $(n=2)$ 


\section{Results}

The analysis of the 1233 plots distinguished 136 community types. These types were split into 9 categories:
A. Native grasslands (Banff and Jasper Mountain ecodistricts)
14 types
B. Native grasslands (Blairmore and Morley Foothills ecodistricts)
22 types
C. Disturbed grasslands (Blairmore and Morley Foothills ecodistricts)
12 types
D. Native shrublands
17 types
E. Conifer types
26 types
F. Mixedwood types
13 types
G. Decidous types
16 types
H. Cutblocks
9 types
I. Cypress Hills
7 types

The dominant plant species, canopy cover, environmental conditions, forage production and carrying capacity are outlined for each community type. 


\section{Montane grassland ecology}

The Montane subregion has highly variable ecological conditions. Much of the variation is the result of complex topography, while the small size of individual ecosystems results in a strong ecotonal effect from the surrounding environments (Strong 1992). Much of the grassland vegetation occurs on south and west facing slopes where seasonally low rainfall coupled with high evapotranspiration, dries the soil sufficiently to kill tree seedlings (Daubenmire 1978). Fire is also an important factor in determining the composition of grasslands because of the high flammability of the vegetation during the dry periods. A lack of fire and an increase in annual precipitation favours the growth of trees onto the more mesic sites.

The Whaleback ridge, Porcupine Hills and south into the Castle area are composed of a mixture of rough fescue grassland, aspen, Douglas fir and lodgepole pine. This area is characteristic of the Blairmore and Morley Foothills ecodistricts (Strong and Thompson 1995) an area of ridged and rolling hills, with moderate slopes (6-30\%) and Black Chernozemic soils on submesic to mesic sites. In the Banff and Jasper river valleys and northern Montane areas (Grande Cache, Red Deer river valley) open Douglas fir, lodgepole pine and Fringed sage/Junegrass communities are common on steep south facing slopes, shallow rocky soils and coarse textured outwash (Strong 1992). These areas are typical of the Banff and Jasper Mountain ecodistricts. These ecodistricts have steep slopes (10-45\%) and are dominated by Eutric Brunisolic soils, with submesic to xeric moisture regimes (Strong 1992).

The Cypress Hills ecodistrict is an unglaciated plateau ranging in elevation from about $1300 \mathrm{~m}$ in the east to $1465 \mathrm{~m}$ at the highest point. Once considered boreal foothills, the area has been reclassified as montane given the bimodal summer precipitation peaks (June and September), the potential for freezing temperatures in all months and the combination of closedcanopied lodgepole pine forest with fescue grassland (Strong and Leggatt 1992). Soil parent materials are somewhat unique on the plateau where ancient tertiary gravels are exposed, or, may be capped by a variable veneer of loess; fine silty material deposited by wind from post glacial lake beds to the west of the plateau. Soils are mostly Black Chernozems where grassland vegetation has dominated. Thelma soils are loamy Orthic Black Chernozems associated with rough fescue communities on the top of the bench. Also associated with rough fescue cover, Delmas and Marmaduke soil series are gravel and shallow to gravel Orthic Dark Brown Chernozems found on the shoulder of the escarpment. Orthic Dark Grey Luvisols, like the soils series Reesor (loamy) have developed where lodgepole pine or aspen forest have prevailed (Greenlee 1981). The grassland community types of the Montane subregion are outlined in Table 2.

\section{Banff and Jasper Mountain ecodistricts}

The two dominant grassland communities in Banff and Jasper National Park include the Fringed sage/Junegrass and Northern wheatgrass-Sheep fescue community types. These communities are typical of steep, south and westerly facing slopes with xeric to subxeric moisture regimes. The soils are poorly developed and nutrient poor. Variants of these community types included the Pussy toes/Junegrass community, which is also found on shallow, 


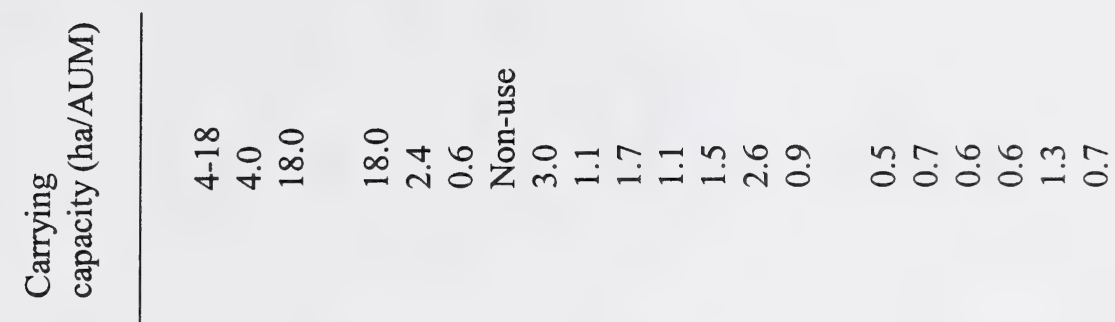

离

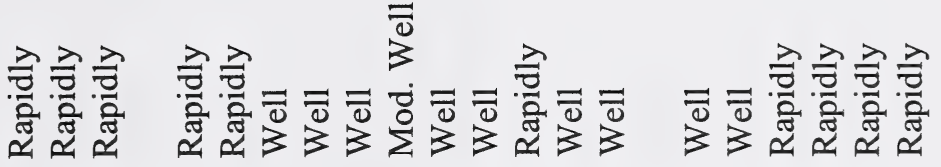

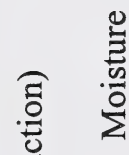

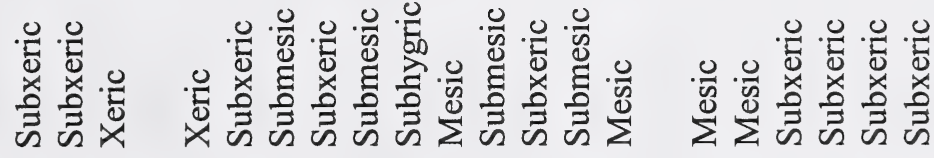

율

요

츨 을

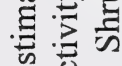

莺

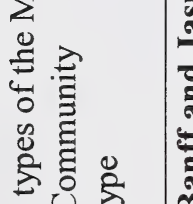

(3)

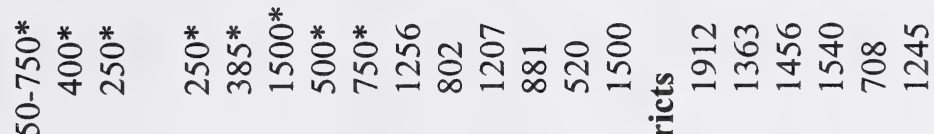

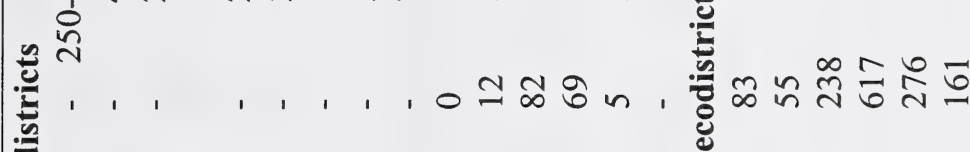

巳

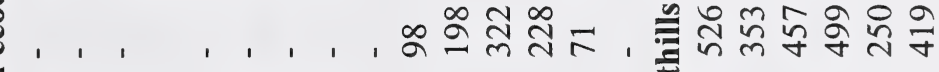

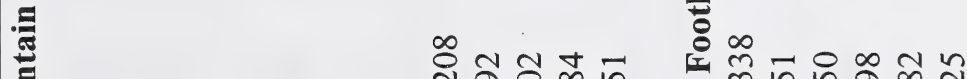

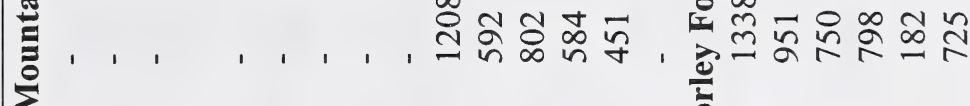

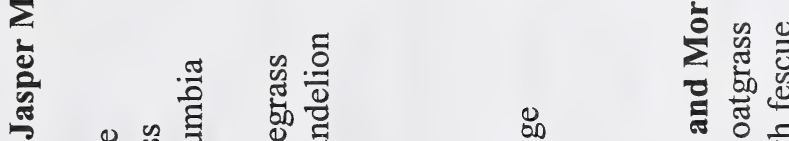

ت

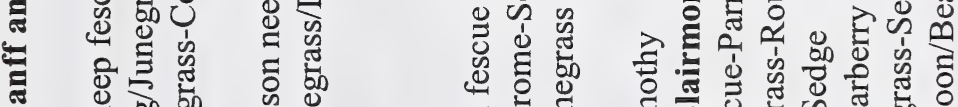

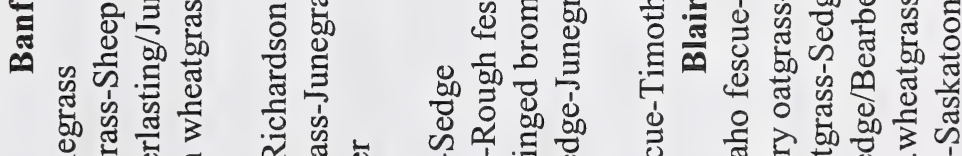
क्ष

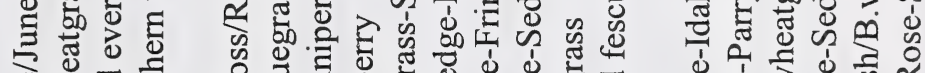
ఏ

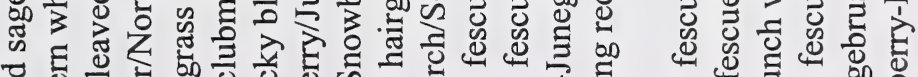
ठ E ङ

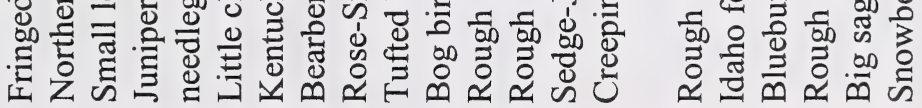

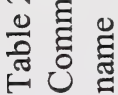

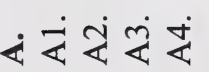

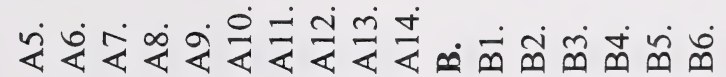




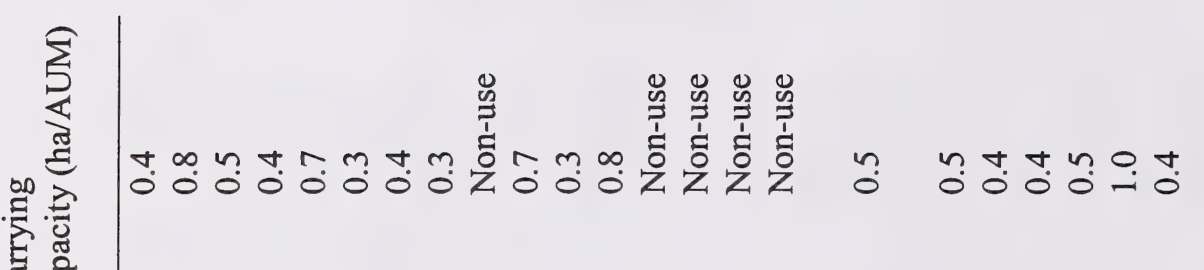
惌

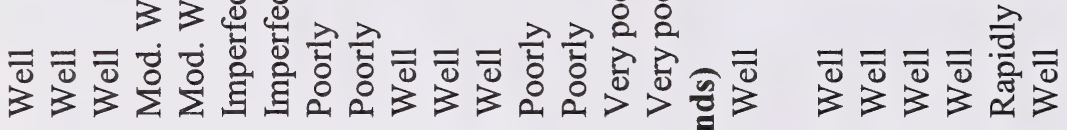

营

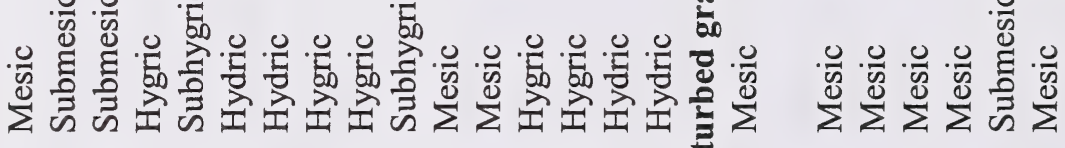

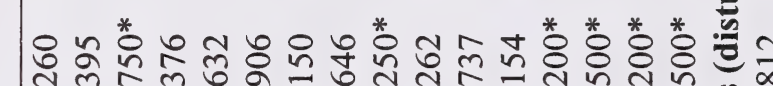

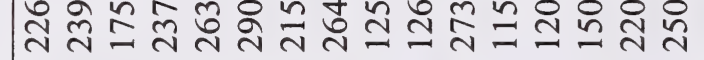

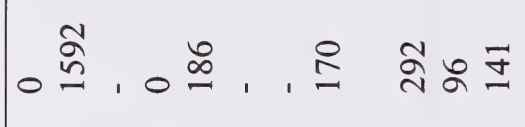

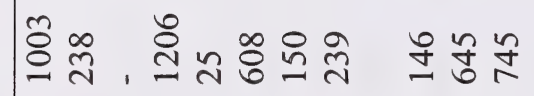

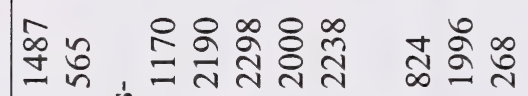

离

究

总就

竞

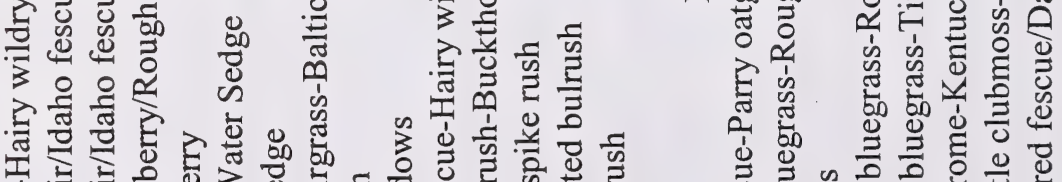

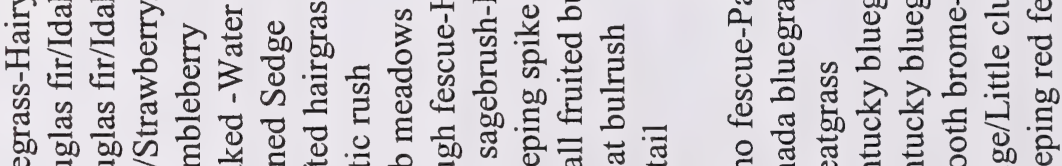

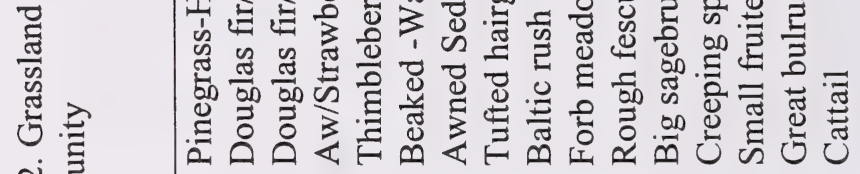

.

을

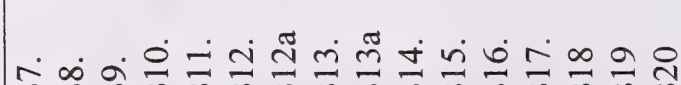

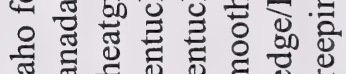

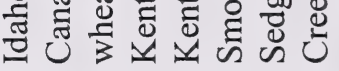

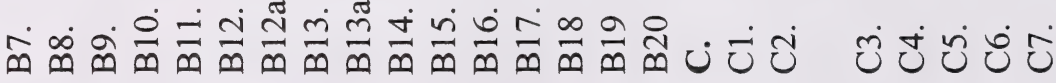



south facing slopes and the Juniper/Northern wheatgrass community which is typical of regosolic, eolian sand dunes of the Athabasca river valley near Jasper (Corns and Achuff 1982). A Little clubmoss/Richardson needlgrass community was also found on shallow south facing slopes in small isolated areas within the fir, white spruce, lodgepole pine and douglas fir forests.

A Kentucky bluegrass-Junegrass/Dandelion community type was described on lower to level slope positions with submesic to subxeric moisture regimes. The presence of a high cover of Junegrass indicates the close affinity this grassland has with the Fringed sage/Junegrass community type. The high cover of Kentucky bluegrass is indicative of heavy grazing influence on this community type.

There were two upland shrub communities found on steep south facing slopes (Bearberry/Juniper and Rose-Snowberry). These community types represented the transition from grassland to forest. The Bearberry/Juniper community type represents the transition from the grassland communities to the dry lodgepole pine, douglas fir and spruce forests. In contrast the Rose-Snowberry shrubland appears to represent the transition to moister deciduous and spruce forests.

The grasslands in the Ya Ha Tinda area of the Banff and Jasper ecodistricts are transitional between the grasslands described in Banff and Jasper National Parks and the grasslands in the Morley and Blairmore Foothills ecodistricts of southern Alberta. Rough fescue is common in the Ya Ha Tinda which gives these grasslands some affinity to the rough fescue dominated grasslands in Southern Alberta. The predominance of junegrass and northern wheatgrass in the Ya Ha Tinda also gives these grasslands some affinity to the grasslands described near Banff and Jasper. The grasslands of the Ya Ha Tinda tend to be dry and well drained. They occur on south and west facing slopes and coarse textured fluvial areas. The dry slopes tend to have a predominance of rough fescue, sedge and junegrass. In contrast the level fluvial areas have a predominance of rough fescue and fringed brome. There are a number of community types in the Ya Ha Tinda that are transitional to the Upper Foothills and Subalpine subregions. These include the Tufted hairgrass-Sedge and Bog birch/Sedge-Rough fescue dominated community types.

\section{Blairmore and Morley Foothills ecodistricts}

The dominant grassland community types of these ecodistricts near the Porcupine hills and south into the Castle area are outlined in Figures 1 and 2. The Rough fescue-Idaho fescueParry oatgrass dominates mesic to submesic, lower slope positions and terraces with Black Chernozemic soils. Situated upslope from this plant community on slightly drier sites with poorer soils, Parry oatgrass and Idaho fescue replace rough fescue as the dominant grass to form the Idaho fescue-Parry oatgrass-Rough fescue community type. The Bluebunch wheatgrassSedge community is found on steep south-facing slopes with Regosolic and Brunisolic soils. Further upslope on dry sandstone outcrops and xeric hillcrests, limber pine dominated community types are very common. A Rough fescue-Sedge/Bearberry-dominated community type is found on hilltops throughout the area. This type tends to be drier than the lower slope dominated rough fescue community type, but it is moister and not as rapidly drained as the Bluebunch wheatgrass-Sedge and limber pine dominated community types. Douglas fir invasion 
is common on these hilltop community types, to form the Douglas fir/Idaho fescue-Rough fescue and Douglas fir/Idaho fescue-Sandberg bluegrass community types. At higher elevations the ecotone between forest and grassland is dominated by the Snowberry-Rose-Saskatoon/Bearberry community type on drier sites and by the Pinegrass-Hairy wildrye community on moister sites with northerly aspects.

A Big sagebrush/Bluebunch wheatgrass-Sedge community type was described on a gravelly south facing slope south of Blairmore. This community type is rare in Alberta and appears to be an extension of the Palouse prairie from Eastern Washington (Moss 1947).

There are a number of community types that are characteristic of moist, poorly drained, nutrient rich sites. These include Thimbleberry brush, Sedge meadows, Tufted hairgrass-Baltic rush and Forb meadows. The Tufted hairgrass-Baltic rush community has plant species that are more characteristic of the Subalpine subregion (Willoughby 1999) and may represent the transition to the subalpine. Thompson and Hansen (2002) have described a number of graminoid wetland dominated communities. These types have been included in this guide. These types include Water, Beaked and Awned sedge, creeping spike rush, bulrush and cattail dominated meadows. These community types are not common in the higher elevations of the Montane and are generally found in the eastern part of the Montane and are transitional to the Foothills Fescue and Foothills Parkland subregions.

There are a number of different grassland community types that have been influenced by grazing pressure. Increased grazing pressure on a rough fescue dominated community type leads to a decline in rough fescue and an increase in Parry oatgrass and Idaho fescue to form the Idaho fescue-Parry oatgrass-Sedge community (Willoughby 1992). Continued heavy grazing pressure allows Kentucky or Canada bluegrass to establish to form the Kentucky bluegrass-Rough fescue or Canada bluegrass-Rough fescue community types. Continued heavy grazing pressure eventually leads to a decline in all native species and the site is dominated by Kentucky bluegrass and dandelion to form the Kentucky bluegrass $\backslash D$ andelion community type. There are a number of community types that have been seeded to tame forage species through cultivation or reclamation. These include the Smooth brome-Kentucky bluegrass and Creeping red fescue/Dandelion-Clover community types.

On the drier slopes increased grazing pressure on the Idaho fescue-Parry oatgrass-Rough fescue and Bluebunch wheatgrass community types leads to an increase in low growing forbs and graminoids to form the Sedge/Little clubmoss-Moss phlox community type. On moister sites in these community types, grazing disturbance also leads to the formation of Parry oatgrassTimothy and Northern wheatgrass-Kentucky bluegrass dominated community types.

\section{Cypress Hills ecodistrict}

Plant communities described in the Cypress Hills are associated with the nearly level plateau or the upper edges of the steep escarpment or rolling uplands. They include a mixture of rough fescue grassland and closed canopy aspen and lodgepole pine dominated forests. The Rough fescue (Festuca campestris Rydb.) related plant communities of the Cypress Hills Plateau are unique in the relatively high canopy of Shrubby Cinquefoil (compared to fescue communities 
described in southwestern Alberta and appears to be a function of the gravelly soil) and the abundance of Intermediate oat grass, a major subdominant grassland species (Moss 1955). On the steep, dry slopes Western Porcupine grass often replaces Intermediate oatgrass in these grassland communities. Idaho fescue also replaces Intermediate oatgrass on shallower soils with gentler slopes. An unresolved issue is the apparent expression of Rough fescue as the Foothills Rough fescue ( $F$. campestris Rydb.) bunch grass type on the top of the plateau and the Plains Rough fescue (F. hallii Vassey) rhizomatous form on the adjoining slopes of the Cypress Hills. 


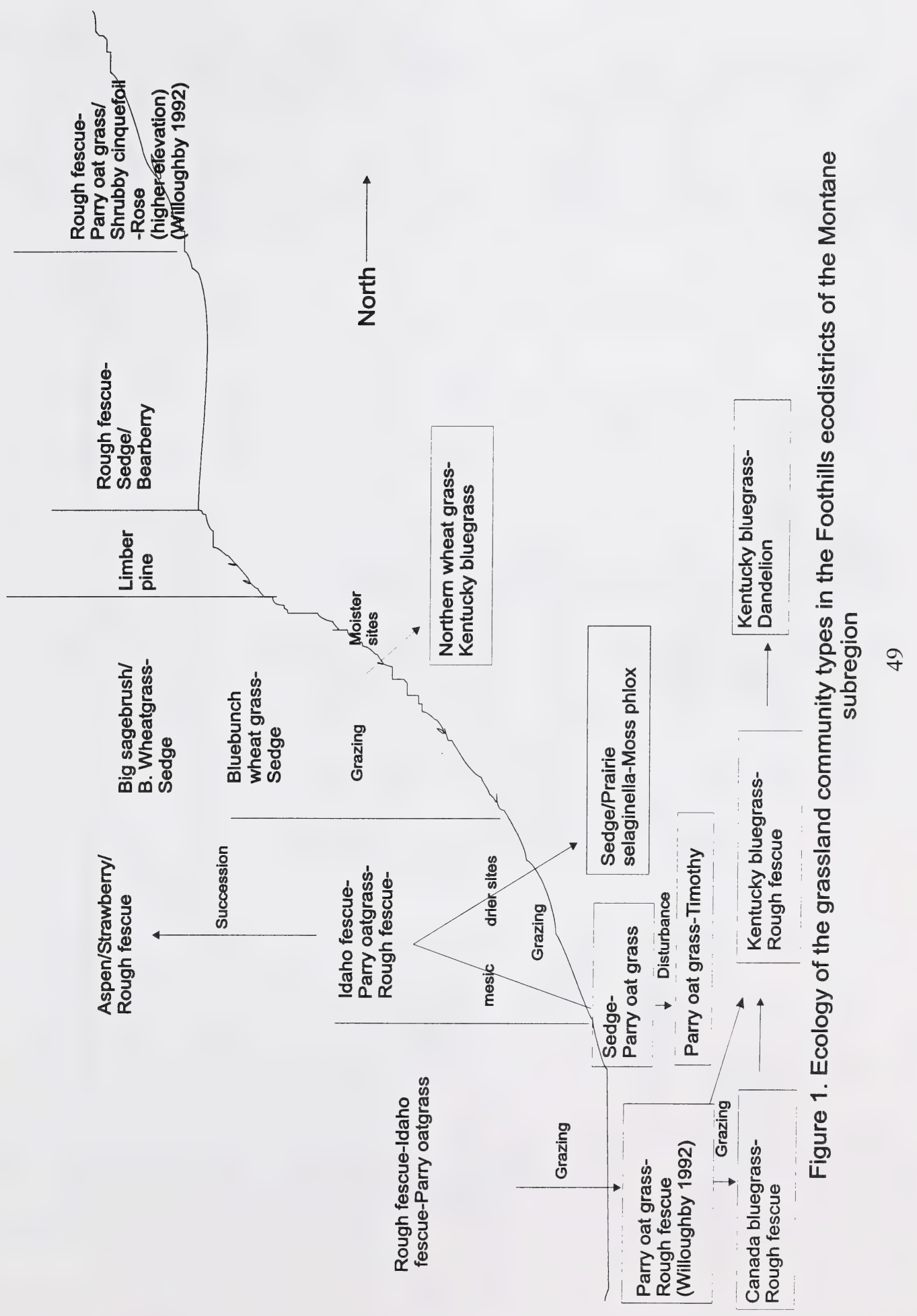




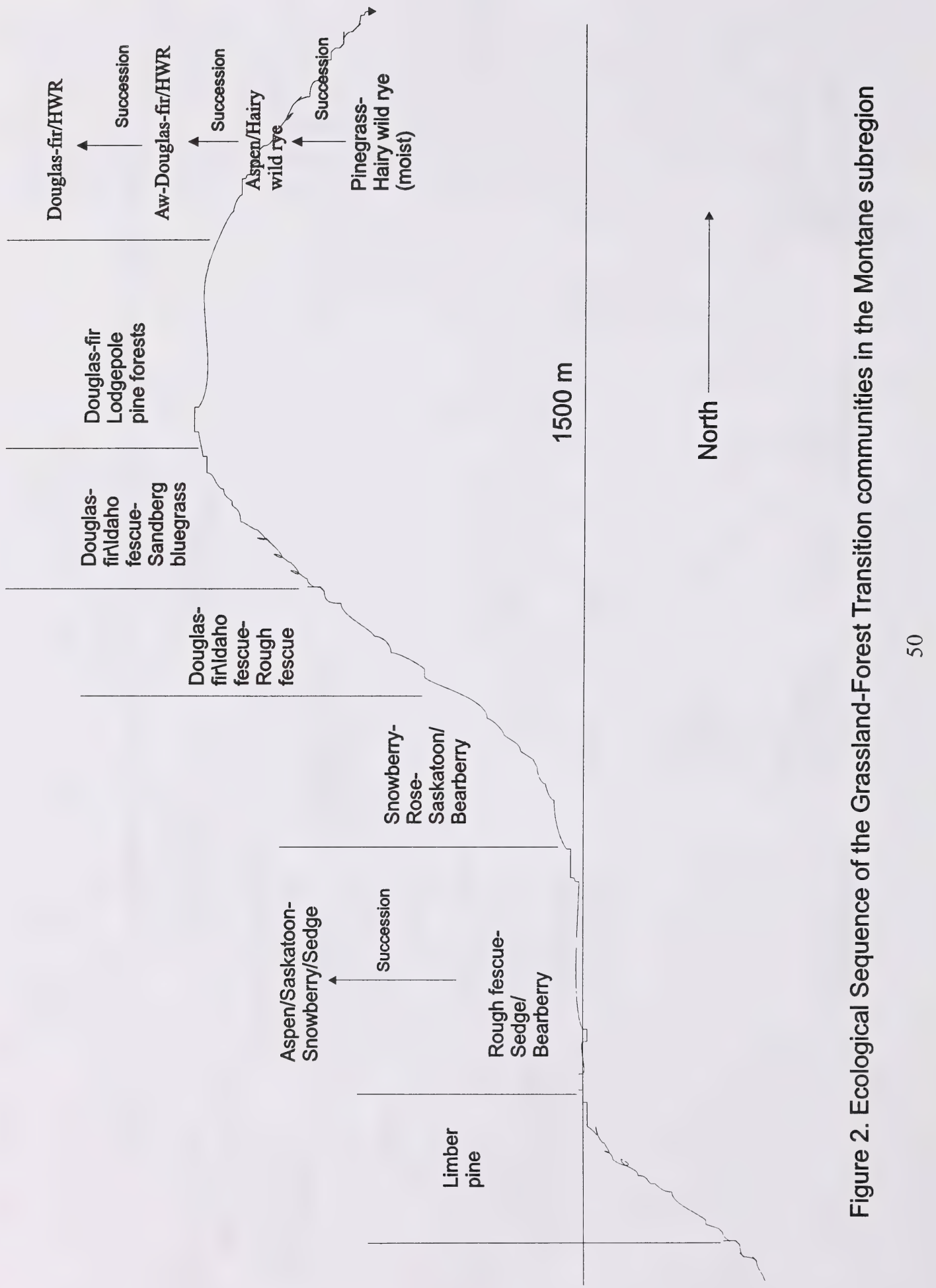




\section{Native grassland kev}

1. Grasslands found in Banff, Jasper, Ya Ha Tinda or Cypress Hills

Grasslands found in the Porcupine Hills, Castle, Gap or Whaleback.....Blairmore and Morley Foothills ecodistricts

2. Grasslands found in Banff, Jasper or Ya Ha Tinda

Banff and Jasper Mountain ecodistricts

Grasslands found in the Cypress Hills. Cypress Hills ecodistrict

\section{Blairmore and Morley Foothills ecodistricts}

1. Grassland shows signs of extensive grazing pressure, such as a reduction in tall forbs, and an increase in invader species such as Kentucky bluegrass, dandelion, Timothy, Creeping red fescue, and Smooth brome, Orchardgrass.Disturbed grasslands Native grasslands, recovering grasslands, or invaded exclosure sites dominated by Rough fescue, Parry oatgrass, Idaho fescue, and Bluebunch wheatgrass, and invaded by Kentucky bluegrass or Mountain brome(also includes grasslands being encroached by trees $\mathrm{Fd}, \mathrm{Aw}$ ).....

2. Grassland forest transition. Aw, Fd, Pinegrass, Snowberry, Saskatoon, and Rose present in the canopy.............. 3 South facing slopes or hilltops dominated by, Rough fescue, Parry oatgrass, Bluebunch wheatgrass, Big sagebrush or, depressional or seepage areas dominated by Thimbleberry, sedges, bulrushes or cattails. Site may or may not contain tame species such as Kentucky bluegrass and Mountain brome.................................................................................... 7

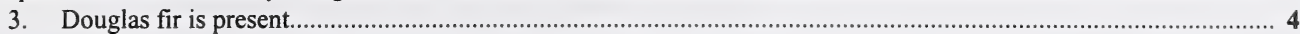

Aw, Pinegrass, snowberry, Saskatoon, Rose or Bearberry dominant.

4. Idaho fescue and Rough fescue are dominant and the community is a transition between fescue grassland and Douglas fir

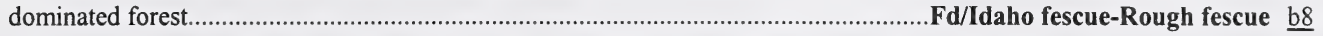
Idaho fescue and Sandberg bluegrass are dominant. Site is also a transition to Douglas fir forest, but is much drier than the above as is indicated by the presence of Sandberg bluegrass, Little club moss and Fringed sage.

5. Moist mesic sites(pinegrass dominated or aspen invaded grasslands).

Fd/Idaho-fescue-Sandberg bluegrass $\underline{b} 9$

Dry or seepage sites containing bearberry snowberry-Saskatoon, and rough fescue. A transition site between Rough fescue dominated grasslands and Douglas fir and Lodgepole pine dominated forests.Snowberry-Rose-Saskatoon/Bearberry b6 6. Sites dominated by Pinegrass and Hairy wildrye. Area receives some seepage throughout the growing season and has a high forb cover. High moisture of the site allows for production of over $2000 \mathrm{~kg} / \mathrm{ha}$..Pinegrass-Hairy wildrye $/ \mathrm{Strawberry} \underline{\mathrm{b} 7}$ Sites dominated by Rough fescue and Strawberry, and is a transition from a Rough fescue dominated grassland to an Aspen dominated forest. Aspen trees have moved onto a fescue grassland and the understory is moving towards a Strawberry/Slender wheatgrass, and this community type is part of the transition......................................Aw/Strawberry/Rough fescue b10

7. Moist sites dominated by Thimbleberry, sedges, bulrushes, Cattails Lindley's aster and Wild bergamont, Tufted hairgrass, or Big sagebrush-Buckthorn.....

Lower slopes with deep soils, and moist conditions, or Hilltops and steep south facing slopes, Bluebunch wheatgrass, Big sagebrush, Rough fescue, and Sedge dominant...................................................................................... 12

8. Sites are nutrient rich seepage areas dominated by Thimbleberry.

Thimbleberry b11 Sites dominated by sedges, bulrushes, cattails, Lindley's aster and Wild bergamont, Tufted hairgrass, or Big sagebrushBuckthorn

9. Sites are commonly wet, experience periodic flooding, and dominated by sedges, bulrushes, rushes or cattails........9a Sites dominated by Lindley's aster and Wild bergamont, Tufted hairgrass, or Big sagebrush-Buckthorn................ 10

9a Wet sites dominated by sedges.

Wet sites dominated by bulrushes, rushes or cattails.

$9 \mathrm{~b}$ Sites dominated by water or beaked sedge. Sites dominated by awned sedge.

Beaked-Water sedge b12 Awned sedge b12a

9c Site dominated by bulrush or rush species. Site dominated by cattails or creeping spike rush.

Grazed site dominated by baltic rush. .9f Ungrazed site dominated by bulrushes.

9e Site dominated by small fruited bulrush. Very wet site dominated by great bulrush.

9f Very wet sites dominated by cattails. Boggy sites dominated by creeping spike rush Baltic rush $\frac{\text { b13a }}{9 \mathrm{e}}$ Small fruited bulrush b18 Great bulrush b19 Cattails b20

Creeping spike rush b17

10. Sites is a small isolated forest opening dominated by forbs specifically Lindley's aster and Wild bergamont. Sites tend to be moist and well drained and probably receive some nutrient seepage at some point in the year.. Forb meadows $\underline{b 14}$

Sites dominated by Tufted hairgrass, or Big sagebrush-Buckthorn

11. Sites dominated by Tufted hairgrass, and are located on moist meadows at higher elevations and slightly drier than the Sedge meadows community type. ...Tufted hairgrass-Baltic rush b13 
Sites dominated by Big sagebrush-Buckthorn. Sites dominated by Buckthorn will be moist areas of meadows with fine textured soils. Big sagebrush dominated sites will found on drier creek beds with gravely soils......

Big Sagebrush-Buckthorn/Kentucky bluegrass $\underline{\mathrm{b} 16}$

12. Lower slope sites with deep soils. Rough fescue, Parry's oatgrass, or Idaho fescue Hairy wildrye dominant........... 13

Hilltops and steep south facing slopes. Bluebunch wheatgrass, Big sagebrush, Rough fescue and sedge dominant.. 18

13. Mesic lower slope and level areas, Rough fescue dominant.................................................................... 14

Upper slopes, Parry oatgrass, Idaho fescue dominant............................................................................. 17

14. Site is predominantly native species very little tame species.................................................................... 15

Site shows signs of extensive grazing pressure, particularly the reduction in tall forbs and the invasion of tame grass species

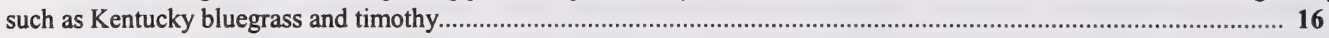
15. Site is the modal grassland community type on Black Chernozemic soils in the foothills of southern Alberta. On rocky and gravelly slopes Rough fescue is replaced by Parry's oatgrass and Idaho fescue.

Rough fescue-Idaho fescue-Parry oatgrass bl

Site represents the transition between the lower Montane subregion and the higher Subalpine region (hairy wildrye codominant)...

Rough fescue-Hairy wildrye b15

16. Site is found in lower slope positions that have been moderately grazed. Mountain brome has invaded.

..Rough fescue-Sedge-Mountain brome $\underline{\mathrm{cl} 0}$

Site has been heavily grazed to the point that Kentucky bluegrass has invaded, and is now recovering or is an ungrazed exclosure that has been invaded by Kentucky bluegras........................................Rough fescue-Kentucky bluegrass c9 17. Site occupies lower slope positions and represents a Rough fescue-Idaho fescue-Parry oatgrass community type that has been moderately or heavily grazed for a number of seasons....... .Idaho fescue-Parry oatgrass-Sedge $\underline{\mathrm{cl}}$

Site is up slope and is drier than the Rough fescue-Parry oatgrass-Idaho fescue community type and is dominated by Parry oatgrass or Idaho fescue. ..Idaho fescue-Parry oatgrass-Rough fescue $\underline{\mathrm{b} 2}$ 18. Site is located on hilltops, and has shallow poorly developed soils. This community is drier than Rough fescue communities in lower slope positions, and wetter than the Bluebunch wheatgrass community found on southerly slopes. Rough fescue, sedge, and Bearberry are dominant. Rough fescue-Sedge/Bearberry $\underline{b 4}$

Site is located on a south facing slope. 19

19. Site is dominated by Big sagebrush, and located on gravelly south facing slopes.

Big sagebrush/Bluebunch wheatgrass $\underline{\mathrm{b} 5}$

Site is dominated by Bluebunch wheatgrass and sedge, or site is moderately grazed and dominated by Sedge, Moss phlox and Little club moss.. 20

20. Bluebunch wheatgrass is dominant. Site is found on well drained south facing slopes

Bluebunch wheatgrass-Sedge $\underline{b 3}$

Moderately grazed gravelly site within the Parry oatgrass-Rough fescue and Bluebunch wheatgrass dominated community types. Sedge, Moss phlox and Little club moss are dominant.. Sedge/Little clubmoss-Moss phlox c6 Disturbed grassland key

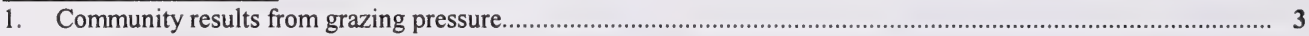

Community results from seeding an area with tame grasses................................................................... 2

2. Site is a natural gas pipeline or power transmission line that has been seeded to Creeping red fescue. Originally the site was a rough fescue grassland.

Creeping red fescue/Dandelion-Clover $\underline{c 7}$

Site was once a Rough fescue dominated community, but it has been cultivated and seeded to Smooth brome or orchardgrass.

2a Smooth brome dominated community.

Smooth brome-Kentucky bluegrass c5

Orchardgrass present, Aspen maybe invading.

3. Dry sites.. .Aw/Orchardgrass-K. bluegrass

Mesic and moist sites.

4 Site is a dry site found at lower slope positions dominated by Idaho fescue and Parry oatgrass. Grazing caused a decrease in Rough fescue and an increase in Idaho fescue, Parry oatgrass and sedge. Eventually Kentucky bluegrass is expected to invade Idaho fescue-Parry oatgrass-Sedge

Site dominated by Northern wheatgrass, Sedge and Little club moss, or Canada bluegrass. $\frac{\mathrm{cl}}{5}$

5. Site found on dry moderately to heavily grazed south facing slopes with shallow soils above the Oldman river. Community is dominated by Northern wheatgrass..

Sites dominated by Sedge and Little clubmoss, or Canada bluegrass Northern wheatgrass-Kentucky bluegrass $\underline{\mathrm{c} 8}$

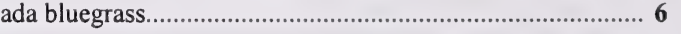

6. Site is dry and gravelly in a Parry oatgrass-Rough fescue and Bluebunch wheatgrass dominated community type. Site is dominated by Sedge and Little clubmoss.........................................................Sedge/Little club moss-Moss phlox c6

Site is on shallow nutrient poor soils on lower slope positions, indicative of communities containing Canada bluegrass, blunt sedge, Junegrass, and Plains reedgrass...........................Canada bluegrass-Rough fescue-Slender wheatgrass $\mathrm{c} 2$

7. Site is found on lower slope positions along the valley bottoms of the Porcupine Hills. Sites contain sufficient moisture to 
support the growth of Snowberry and Kentucky bluegrass.

Snowberry/Kentucky bluegrass $\underline{\mathrm{c} 11}$

Sites found on the lower sections of south facing slopes with mesic to subhygric moisture regimes and no Snowberry 8

8. Site contains Mountain brome

Rough fescue-Sedge-Mountain brome

Sites where Kentucky bluegrass is a dominant component.

Kentucky bluegrass-Timothy/Dandelion $\quad \underline{\mathrm{c} 4}$

9. Timothy is a major grass in the community

No or little Timothy in the community.

10. Heavily grazed grassland which is recovering, Rough fescue is more prevalent than Kentucky bluegrass.

Rough fescue-Kentucky bluegrass $\underline{\mathrm{c} 9}$

Heavily grazed grassland, Kentucky bluegrass is more prevalent than the native species in community.

\section{Banff and Jasper Mountain ecodistricts}

Kentucky bluegrass-Rough fescue c3

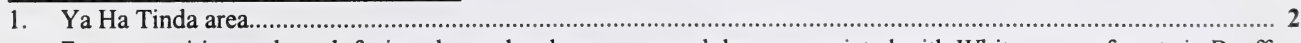

Forest transition and south facing slopes, level areas, or sand dunes associated with White spruce forests in Banff and Jasper

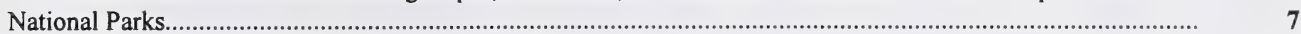

2. Moist sites dominated by Tufted hairgrass and Bog birch.................................................................... 3

Mesic sites dominated by Rough fescue, Sedge, and Junegrass................................................................... 4

3. Site is moist and better drained than pure sedge meadows. Tufted hairgrass dominates the vegetation.

Tufted hairgrass-Sedge $\underline{\text { a9 }}$

Site is a fescue grassland invaded with Bog birch. Bog birch, Rough fescue, Sedge are dominate

4. Rough fescue dominated

Bog birch/Sedge-Rough fescue a10

Grazing modified or cultivated. 3 9

Site occurs on steeper, morainal and colluvial slopes. There is little Fringed brome on the site because of the dry site conditions, Junegrass is predominant....

Site is located on coarse textured fluvial areas and moister south and west facing slopes. Rough fescue, Sedge, and Fringed brome are dominant.

Rough fescue-Fringed brome-Sedge all

6. Site has coarse textured fluvial soils and has been modified by grazing. Sedge and Junegrass dominate the site..........

Sedge-Junegrass a13

Site is a spruce cutblock that was seeded to Creeping red fescue and Timothy.....Creeping red fescue-Timothy al4

7. Forest transition. Little clubmoss, Richardson needlegrass, Bearberry, Juniper, Rose, Snowberry dominant........ 8

South facing slopes and level areas. Ungrazed sites dominated by Fringed sage, Northern wheatgrass, Junegrass, and Small

leaved everlasting or sand dunes associated with White spruce forests. Grazed sites dominated by Kentucky bluegrass,

Dandelion, and Junegrass.....

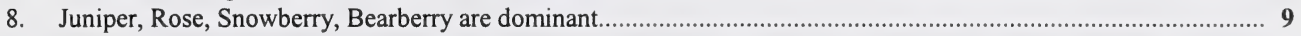

Site is located on an isolated south facing slope within the Pine-Spruce-Fir forests at higher elevations. Richardson

needlegrass present Little clubmoss/Richarson needlegrass as

9. Site is a forest-grassland ecotone on dry, rocky south facing slope in the Banff and Jasper river valleys. Bearberry and

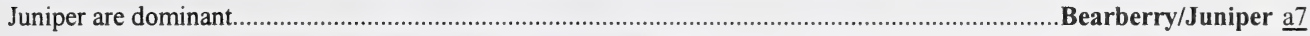

Site is a forest grassland ecotone on south facing slopes both in the Mountain and foothills ecodistricts. Area is moister with better developed soils than the Bearberry/Juniper community type. Moving towards a deciduous dominated forest. Rose and Snowberry dominant in the understory. Rose/Snowberry

10. Level areas. 12

Lower elevations, sand dunes, or higher elevations.

11. Gravelly soils found in the level areas in the Athabasca and North Saskatchewan river valleys near Jasper and Saskatchewan crossing. Small-leaved everlasting dominant .Small-leaved everlasting/Junegrass a3

Grazed fescue grassland sites on lower and level slope positions with submesic to mesic moisture regimes. Kentucky bluegrass and dandelion dominant. Kentucky bluegrass-Junegrass/Dandelion $\underline{\text { a } 6}$

12. Site is found on the dry south facing lower slopes in the river valleys near Banff and Jasper. South facing slopes and the dessicating winds contribute to a climate similar to the Mixed Prairie subregion. Fringed sage and Junegrass dominant.

Sand dunes and higher elevations than above community. Fringed sage/Junegrass $\frac{\mathrm{a} l}{13}$

13. Area is sand dunes with white spruce stands growing in the mesic depressions between the sand dunes. This community type occupies lower elevation, dry, steep slopes, and is dominated by Juniper......

..Juniper/Northern wheatgrass-Columbia needlegrass $\underline{\text { a } 4}$

Site occupies the dry steep south facing slopes slightly higher elevations than Fringed sage/Junegrass. Northern wheatgrass and sheep fescue are dominant..

Northern wheatgrass-Sheep fescue a $\underline{\text { a }}$ 


\section{Cypress Hills ecodistrict}

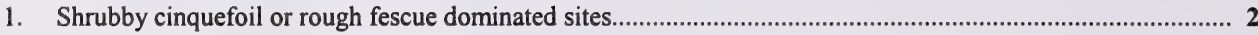

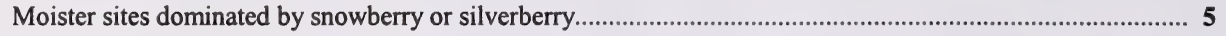

2. Shrubby cinquefoil dominated communities..................................................................................... 3

Shrubby cinquefoil greatly reduced, site is found on slopes and dominated by Foothills rough fescue and Western porcupine grass...................................... Foothills rough fescue-Western porcupine grass I1

3. Ungrazed communities dominated by rough fescue and codominated by Intermediate oatgrass or Idaho fescue. 4 Patched grazed community dominated by rough fescue and golden bean .. Shrubby cinquefoil/Foothills rough fescue-Golden bean $\underline{\underline{I 3}}$

4. Modal grassland community codominated by Intermediate oatgrass.. Shrubby cinquefoil/Foothills rough fescue-Intermediate oatgrass $\underline{12}$

Site with shallower soils codominated by Idaho fescue....Shrubby cinquefoil/Foothills rough fescueIdaho fescue $\underline{\mathbf{I 4}}$

5. Seepage area dominated by silverberry Silverberry/Kentucky bluegrass $\underline{\mathbf{I}}$ Seepage area dominated by snowberry Snowberry/Kentucky bluegrass $\underline{\mathbf{I 5}}$ 
MONTANE SUBREGION

\section{BANFF AND JASPER MOUNTAIN ECODISTRICTS}

\section{GRASSLAND COMMUNITY TYPES}

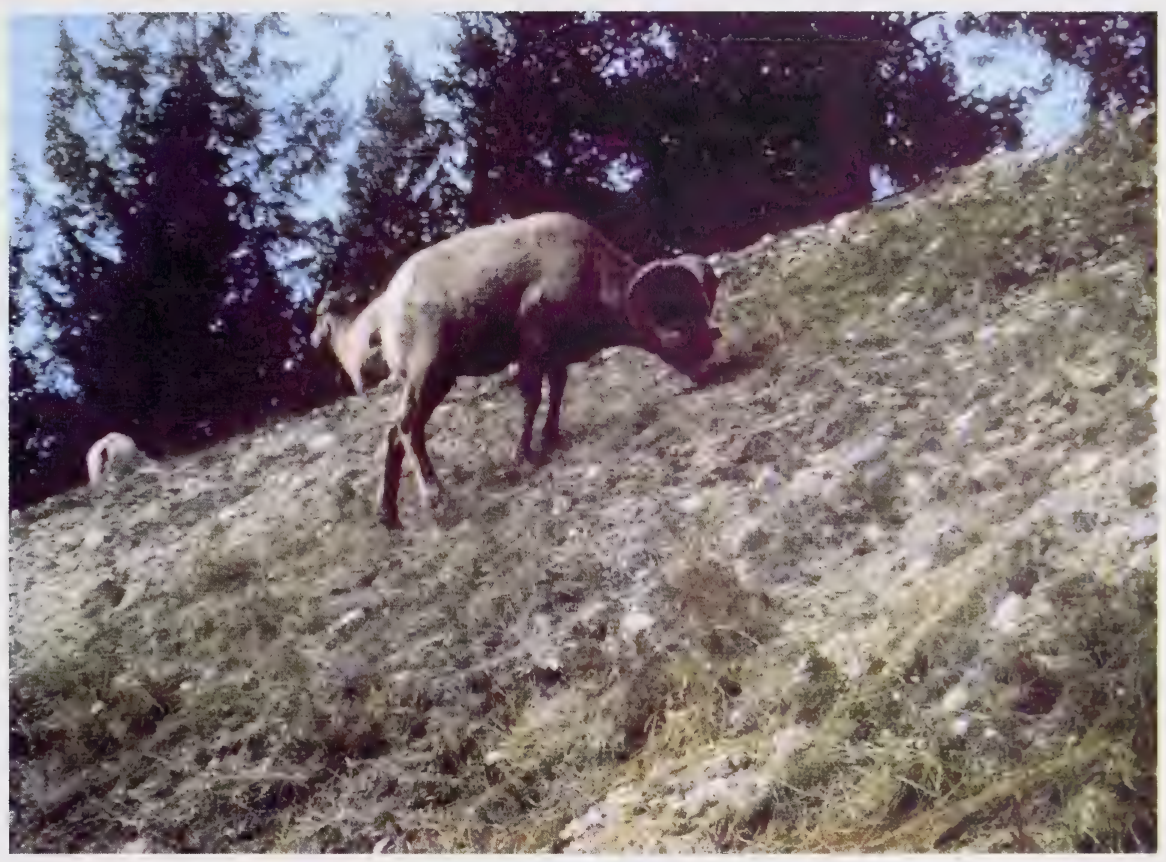

Photo 2: Banff and Jasper Mountain ecodistricts. This is a typical grassland of south-facing slopes in Jasper National Park. The high population of wild ungulates in the National Parks has resulted in heavy use on many of these grassland communities. 


\section{A1. Fringed sage/Junegrass \\ (Artemisia frigida/Koelera macrantha)}

$\mathbf{n}=11$ This community type is typical of steep south facing slopes, at lower elevations in the river valleys near Banff and Jasper. It is similar to the Junegrass-Plains reedgrass community described by Stringer (1973) near Banff and Jasper, the Purple reedgrass/Fringed sage community described by Bailey et al. (1992) in the Yukon and the Fringed sage/Slender wheatgrass community described by Pojar (1982) in Northern British Columbia. The prominent species of these grasslands (junegrass, northern wheatgrass, fringed sage, pussy toes and bearberry) are typical of xerophytic and Mixed Prairie type grasslands throughout Western Canada. The dessicating winds of the area and steep south- facing slopes would contribute to a climate that is similar to the Mixed Prairie subregion (Strong 1992). Grazing has also seemed to have had an influence on this community type. Stringer (1973) felt that with protection from heavy wildlife grazing Plains reedgrass and northern wheatgrass would increase and fringed sage and junegrass would decrease. Bailey et al. (1992), found that fringed sage, pussy toes, bearberry and low growing sedges increased and purple reedgrass declined with increased grazing pressure on the Purple reedgrass/Fringed sage community type. It would appear the dry climate, and heavy grazing pressure by wild ungulates have contributed to the development of this grassland community.

Plant Composition Canopy Cover(\%) Mean Range Const.

SHRUBS

SHRUBBY CINQUEFOIL

(Potentilla fruticosa)

GROUND JUNIPER

(Juniperus communis)

2

$0-10$

36

2

$0-10 \quad 36$

FORBS

FRINGED SAGE

(Artemisia frigida)

BEARBERRY

(Arctostaphylos uva-ursi)2

WILD BLUE FLAX

(Linum lewisii)

3

SMALL LEAVED EVERYLASTING

(Antennaria parviflora) 4

GRASSES

HAIRY WILDRYE

(Elymus innovatus) $\quad 1 \quad 0-5 \quad 36$

JUNEGRASS

$\begin{array}{llll}\text { (Koelera macrantha) } & 16 & 0-40 & 100\end{array}$

PURPLE REEDGRASS

(Calamagrostis purpurascens) $4 \quad 0-15 \quad 55$

NORTHERN WHEATGRASS

(Agropyron dasystachyum)4

\section{ENVIRONMENTAL VARIABLES}

MOISTURE REGIME:

SUBXERIC-XERIC

NUTRIENT REGIME:

SUBMESOTROPHIC

ELEVATION:

1244(990-1720) M

SOIL DRAINAGE:

WELL TO RAPIDLY

SLOPE:

$29(2-65) \%$

ASPECT:

SOUTHERLY

FORAge Production Kg/HA

Total $\quad 250-750 *$ ESTIMATE

SUGGESTED GRAZING CAPACITY

4-18 HA/AUM 


\section{A2. Northern wheatgrass-Sheep fescue (Agropyron dasystachyum-Festuca saximontana)}

$\mathbf{n = 5} \quad$ This community type is similar to the Fringed sage/Junegrass community type. It occupies dry, steep, south facing slopes at slightly higher elevations than the Fringed sage/Junegrass community in the river valleys near Banff and Jasper. This community type appears to be in better range condition than the Fringed sage/Junegrass community type. As Stringer (1973) found, when the Fringed sage/Junegrass type was protected from grazing northern wheatgrass increased in cover. The higher elevation of these sites may restrict access to wild ungulate grazing. Consequently, it would appear this community type is not grazed as heavily as the Fringed sage/Junegrass community type.

Plant COMPOSITION CANOPY COVER(\%) MEan Range Const.

SHRUBS

SASKATOON

(Amelanchier alnifolia)

$0-18 \quad 20$

FORBS

COMMON FIREWEED

(Epilobium angustifolium) 1

SMALL LEAVED EVERLASTING

(Antennaria parviflora) 1

SILKY PERENNIAL LUPINE

(Lupinus sericeus)

YELLOW BEARDS TONGUE

(Penstemon confertus)

2

1

$$
0-2
$$

$0-3 \quad 40$

$0-10 \quad 20$

$0-5 \quad 60$

\section{Grasses}

HAIRY WILD RYE

$\begin{array}{llll}\begin{array}{l}\text { (Elymus innovatus) } \\ \text { NORTHERN WHEATGRASS } \\ \text { (Agropyron dasystachyum) } 34\end{array} & 10-60 & 100 \\ \begin{array}{l}\text { SHEEP FESCUE } \\ \text { (Festuca sacimontana) }\end{array} & 2 & 0-1 & 40 \\ \text { JUNEGRASS } \\ \text { (Koeleria macrantha) }\end{array}$

(Koeleria macrantha) $\quad 1 \quad 0-2 \quad 40$

\section{ENVIRONMENTAL VARIABLES}

MoISTURE REGIME:

SUBXERIC

\section{NUTRIENT REGIME:}

SUBMESOTROPHIC

ELEVATION:

1561(1220-1859) M

SOIL DRAINAGE:

RAPIDLY

SLOPE:

$34(5-65) \%$

ASPECT:

SOUTHERLY

Forage Production Kg/HA

Total $\quad 400 *$ Estimate
SugGeSTED GRAZING CAPACITY

4 HAAUM 


\section{A3. Small-leaved everlasting/Junegrass (Antennaria parviflora/Koeleria macrantha)}

$\mathbf{n}=\mathbf{2}$ The two stands described in this community type are from dry, level areas in the Athabasca and North Saskatchewan river valleys near Jasper and Saskatchewan crossing. They are similar to the Fringed sage/Junegrass community type, but lack cover of fringed sage. Small leaved everlasting is known to be well adapted to xeric moisture conditions (Moss 1992) and is known to increase with increased grazing pressure (Stringer 1973, Bailey et al. 1992). Presently, it is not clear why fringed sage is absent from these sites.

\section{Plant Composition Canopy Cover(\%)} Mean Range Const.

\section{SHRUBS}

SHRUBBY CINQUEFOIL.

(Potentilla fruticosa)

$1 \quad 0-1 \quad 50$

\section{FORBS}

SMALL LEAVED EVERLASTING

(Antennaria parviflora) 18

ALPINE MILK VETCH

(Astragalus alpinus) 8

GRACEFUL CINQUEFOIL

(Potentilla gracilis)

FRINGED SAGE

(Artemisia frigida)

1

GRASSES

JUNEGRASS

(Koeleria macrantha) 3

NORTHERN WHEATGRASS

(Agropyron dasystachyum) 1

UPLAND SEDGE

(Carex spp.)

18

$$
5-30
$$

$0-15 \quad 50$

$0-2 \quad 50$

$0-1 \quad 50$

$1-5 \quad 100$

$0-1 \quad 50$

$0-1 \quad 50$

\section{ENVIRONMENTAL VARIABLES}

MOISTURE REGIME:

XERIC

NUTRIENT REGIME:

SUBMESOTROPHIC

ELEVATION:

$1160(1000-1380) \mathrm{M}$

SOIL DRAINAGE:

RAPIDLY

SLOPE:

$1(0-2) \%$

ASPECT:

SOUTH TO WESTERLY

Forage Production KG/HA

Total $\quad 250 *$ Estimate
Suggested Grazing CAPACITY

18 HA/AUM 


\section{A4. Juniper/Northern wheatgrass-Columbia needlegrass (Juniperus horizontalis/Agropyron trachycaulum-Stipa columbiana)}

$\mathbf{n}=\mathbf{2}$ This community type is distinguished from the other grassland community types in the Banff and Jasper river valleys by the presence of a high juniper cover. It occupies lower elevation, steep, xeric slopes with Regosolic and eolian soils. This community type often occurs in association with dense white spruce thickets which occur in mesic depressions between the sand dunes (Corns and Achuff 1982).

\section{Plant COMPOSITION CANOPY COVER(\%)}

\section{MEAN RANGE CONST.}

SHRUBS

PRICKLY ROSE

(Rosa acicularis)

CREEPING JUNIPER

(Juniperus horizontalis) $\quad 16 \quad 2-30 \quad 100$

GROUND JUNIPER

(Juniperus communis) $\quad 4 \quad 0-8 \quad 50$

FORBS

BEARBERRY

(Arctostaphylos uva-ursi)

ROSY EVERLASTING

(Antennaria rosa) $\quad 8 \quad 0-15 \quad 50$

ASCENDING PURPLE MILK VETCH

$\begin{array}{llll}\text { (Astragalus striatus) } & 5 & 0-10 & 50\end{array}$

PRAIRIE GROUNDSEL

(Senecio canus)

$5 \quad 0-10 \quad 50$

GAILLARDIA (BROWN-EYED SUSAN)

(Gaillardia aristata) $3 \quad 0-6 \quad 50$

GRASSES

NORTHERN WHEATGRASS

(Agropyron dasystachyum) 3

COLUMBIA NEEDLEGRASS

(Stipa columbiana)

SHEEP FESCUE

(Festuca saximontana) $\quad 4 \quad 0-8 \quad 50$

RUSH LIKE SEDGE

(Carex scirpoides)
$0-5 \quad 50$

$0-15 \quad 50$

$0-3 \quad 50$

\section{ENVIRONMENTAL VARIABLES}

MOISTURE REGIME:

XERIC

NUTRIENT REGIME:

SUBMESOTROPHIC

ELEVATION:

1285( 1050-1410) M

SOIL DRAINAGE:

RAPIDLY

SLOPE:

$39(30-48) \%$

ASPECT:

SOUTH TO WEST

PARENT MATERIAL:

AEOLIAN

Forage Production Kg/HA

Total $\quad 250 *$ Estimate

SUGGESTED GRAZING CAPACITY

$18 \mathrm{HA} / \mathrm{AUM}$ 


\section{A5. Little clubmoss/Richardson needlegrass (Selaginella densa/Stipa richardsonii)}

$\mathbf{n}=\mathbf{1}$ This community type is representative of small isolated, south facing slopes within the pine-spruce-fir forests. Stringer (1973), described a similar community at higher elevations near Banff and Jasper. Stringer felt this grassland was unrelated to any grasslands in Western North America and thus seemed to be a distinct grassland type characteristic of the moister sites in the Fescue prairies-coniferous forest ecotone of Banff and Jasper.

\section{Plant COMPOSITION CANopy Cover(\%)}

\section{Mean Range Const.}

\section{FORBS}

\section{LITTLE CLUBMOSS}

(Selaginella densa)

SMALL- LEAVED EVERLASTING

(Antennaria parviflora) 8

CUT LEAVED ANEMONE

(Anemone multifida) $\quad 5 \quad-\quad 100$

TUFTED FLEABANE

(Erigeron caespitosus) $\quad 5 \quad$ - 100

NODDING ONION

(Allium cernuum) $\quad 2 \quad-\quad 100$

SMALL FLOWERED BEARDTONGUE

(Penstemon procerus) 2

GRASSES

RICHARDSON NEEDLEGRASS

(Stipa richardsonii) 8

PURPLE REEDGRASS

(Calamagrostis purpurascens)2

JUNEGRASS

(Koeleria macrantha) 2

NORTHERN WHEATGRASS

(Agropyron dasystachyum) 1

LICHEN

100

100

100

100

\section{ENVIRONMENTAL VARIABLES}

MOISTURE REGIME:

SUBXERIC

NUTRIENT REGIME:

SUBMESOTROPHIC

ELEVATION:

$1330 \mathrm{M}$

SOIL DRAINAGE:

RAPIDLY TO WELL

SLOPE:

$15 \%$

ASPECT:

SOUTHWEST
Forage Production KG/HA

TOTAL $\quad 385 *$ Estimate
SugGESTED GRAZING CAPACITY

$2.4 \mathrm{HA} / \mathrm{AUM}$ 


\section{A6. Kentucky bluegrass-Junegrass/Dandelion (Poa pratensis-Koeleria macrantha/Taraxacum offincinle)}

$\mathbf{n}=3$ This community type was described on lower to level slope positions, with submesic to mesic moisture regimes. The presence of a high cover of Kentucky bluegrass is indicative of the heavy grazing influence on this community type. On mesic to subhygric sites in the fescue grasslands heavy grazing pressure is known to cause a decline in native grass species allowing Kentucky bluegrass to increase (Willoughby 1992). The presence of junegrass indicates that this community has some affinity with the Fringed sage/Junegrass community found in the same area. In the absence of grazing this community type may resemble a Rough fescue/Upland sedge community described on hill crests in the Porcupine hills (Willoughby 1992).

Plant COMPOSITION CANOPY COVER(\%) MEAN RANGE CONST.

SHRUBS

SHRUBBY CINQUEFOIL

(Potentilla fruticosa) $\quad 1 \quad 0-3 \quad 67$

CREEPING JUNIPER

(Juniperus horizontalis) $2 \quad 0-7 \quad 33$

FORBS

BEARBERRY

(Arctostaphylos uva-ursi) $3 \quad 0-10 \quad 33$

DANDELION

$\begin{array}{llll}\text { (Taraxacum offincinale) } & 2 & 1-5 & 100\end{array}$

CUT LEAVED ANEMONE

(Anemone multifida) 1

ASCENDING PURPLE MILK VETCH

(Astragalus striatus) 5

(Oxytropis monticola)

$3 \quad 0-10 \quad 33$

GRASSES

KENTUCKY BLUEGRASS

(Poa pratensis) $\quad 33 \quad 20-40 \quad 100$

JUNEGRASS

(Koeleria macrantha) $\quad 14 \quad 0-30 \quad 67$

SLENDER WHEATGRASS

(Agropyron trachycaulum)2 $\quad 0-5 \quad 67$

PARRY OATGRASS

(Danthonia parryii) $2 \quad 0-5 \quad 67$

COLUMBIA NEEDLEGRASS

(Stipa columbiana)
$0-2 \quad 67$

$0-15 \quad 33$

33

$0-15 \quad 33$

\section{ENVIRONMENTAL VARIABLES}

MOISTURE REGIME:

SUBMESIC

NUTRIENT REGIME:

MESOTROPHIC

ELEVATION:

$1328(1110$ - 1495) M

SOIL DRAINAGE:

WELL

SLOPE:

$7(0-21)$

ASPECT:

SOUTH

Forage Production Kg/HA

TOTAL $1500 *$ Estimate

SugGeSted Stocking RATE $0.6 \mathrm{HA} / \mathrm{AUM}$ 


\section{A7. Bearberry/Juniper \\ (Arctostaphylos uva-ursi/Juniperus spp.)}

$\mathbf{n = 1 7}$ This community type represents the forest-grassland ecotone on dry, rocky south facing slopes throughout the Banff and Jasper river valleys. Indeed many of the stands described in this community type were placed into douglas fir and spruce forest types described by Corns and Achuff (1982). Lane et al. (2000), described a similar community type Low northern sedge/Bearberry on rocky hilltops in the Lower Foothills subregion near Hinton.

\section{Plant Composition Canopy Cover(\%)} Mean Range Const.

\section{TREES}

WHITE SPRUCE

(Picea glauca)

LODGEPOLE PINE

(Pinus contorta)

$5 \quad 0-25 \quad 50$

$20-11 \quad 44$

\section{SHRUBS}

JUNIPER

(Juniperus communis,

\begin{tabular}{llll}
$\begin{array}{l}\text { J. horizontalis) } \\
\text { BUFFALOBERRY }\end{array}$ & 8 & $0-35$ & 94 \\
$\begin{array}{l}\text { (Shepherdia canadensis) } \\
\begin{array}{l}\text { SHRUBBY CINQUEFOIL } \\
\text { (Potentilla fruticosa) }\end{array}\end{array}$ & 5 & $0-40$ & 67 \\
\hline
\end{tabular}

FORBS

BEARBERRY

(Arctostaphylos uva-ursi) 33

WHITE CAMAS

(Zigadenus elegans) 3

SMALL LEAVED EVERLASTING

(Antennaria parviflora) 1

GRASSES

RUSH LIKE SEDGE

(Carex scirpoidea)

HAIRY WILD RYE

(Elymus innovatus) $\quad 3 \quad 0-15 \quad 72$

JUNEGRASS

(Koeleria macrantha) $1 \quad 0-3 \quad 39$
MOISTURE REGIME:

XERIC TO SUBXERIC

NUTRIENT REGIME:

SUBMESOTROPHIC

ELEVATION:

1273(1000-1630) M

SOIL DRAINAGE:

WELL TO RAPIDLY

SLOPE:

$28(0-68) \%$

ASPECT:

SOUTHERLY

Forage Production KG/HA

TOTAL 500* *ESTIMATE

SugGeSted GRAZING CAPACITY

NON-USE

ENVIRONMENTAL VARIABLES 


\section{A8. Rose-Snowberry \\ (Rosa acicularis-Symphoricarpos occidentalis)}

$\mathbf{n}=\mathbf{6}$ This community type represents the forest-grassland ecotone on south facing slopes in both the Mountain and Foothills ecodistricts. This community type is moister and has better developed soils than the Bearberry/Juniper community type. This community type appears to be undergoing transition to a deciduous dominated forest. Many of the dominant understory species (rose, strawberry, northern berstraw, tall lungwort and hairy wildrye) are all characteristic of deciduous stands (Willoughby and Downing 1995).

Plant COMPOSITION CANopy COVER(\%)

TREES

Mean Range Const.

WHITE SPRUCE

(Picea glauca)

BALSAM POPLAR

(Populus balsamifera)

$$
1
$$

$0-2$

33

$0-6$

17

\section{SHRUBS}

PRICKLY ROSE

(Rosa acicularis)

SNOWBERRY

(Symphoricarpos albus) 22

BUFFALOBERRY

(Shepherdia canadensis) 1

SASKATOON

(Amelanchier alnifolia) 3

FORBS

BEARBERRY

(Arctostaphylos uva-ursi)1

NORTHERN BEDSTRAW

(Galium boreale)

WILD STRAWBERRY

(Fragaria virginiana)

TALL LUNGWORT

(Mertensia paniculata) $10-4$

LINDLEY'S ASTER

(Aster ciliolatus)

WINTERGREEN

(Pyrola asarifolia)

3

4

$0-22$

33

GraSSES

HAIRY WILDRYE

(Elymus innovatus)

MARSH REEDGRASS

(Calamagrostis canadensis)3
$12 \quad 0-63 \quad 50$

$0-86 \quad 17$
Mean Range Const.

Two SEEDED SEDGE

(Carex disperma)

$\begin{array}{lll}3 & 0-18 \quad 17\end{array}$

\section{ENVIRONMENTAL VARIABLES}

MOISTURE REGIME: SUBMESIC-MESIC

NUTRIENT REGIME: MESOTROPHIC

ELEVATION: 1308(1070-1539) M

SOIL DRAINAGE: WELL

SLOPE:

$$
26(0-65) \%
$$

ASPECT:

SOUTHWEST

\section{Forage Production KG/HA}

Total $\quad 750 *$ Estimate

\section{SUGGESTED GRAZING CAPACITY}

$3 \mathrm{HA} / \mathrm{AUM}$ 


\title{
MONTANE SUBREGION
}

\section{BANFF AND JASPER MOUNTAIN ECODISTRICTS}

\author{
YA HA TINDA AREA
}

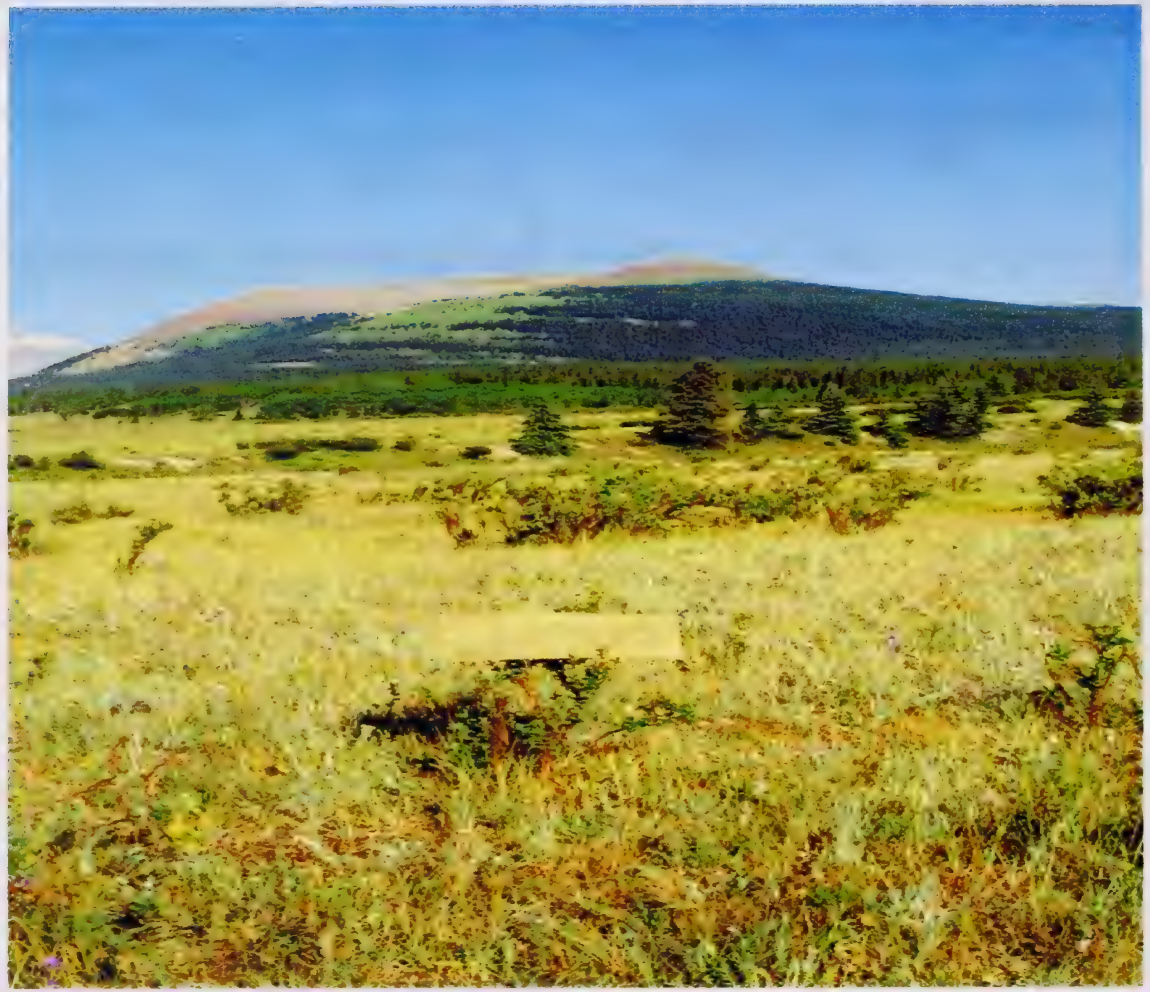

Photo 3: Banff and Jasper Mountain ecodistricts. This is a typical grassland of south-facing slopes and meadows in the Ya Ha Tinda. These grasslands are transitional between the grasslands described in Banff and Jasper National Parks and the Morley and Blairmore Foothills ecodistricts. 


\section{A9. Tufted hairgrass-Sedge \\ (Deschampsia cespitosa-Carex praegracilis)}

$\mathbf{n}=1$ This community type is located on moist sites that are better drained than pure sedge meadows. Willoughby (1992) and Willoughby (1999), found that tufted hairgrass is a common plant species on these lowland sites throughout the Upper Foothills and lower Subalpine subregions. The presence of this community type in the Ya Ha Tinda indicates that many of the grasslands in this area are transitional to the Upper Foothills and Subalpine subregions. Morgantini and Russell (1983), found that elk preferred the rough fescue dominated areas over these tufted hairgrass dominated communities at Ribbon flats just west of the Ya Ha Tinda. As a result this community type would be rated as secondary or non-use range for elk and horses in the Ya Ha Tinda area.

\section{Plant Composition CanopyCover(\%)} Mean Range Const.

\section{SHRUBS}

SHRUBBY CINQUEFOIL

(Potentilla fruticosa)

1

100

FORBS

GRACEFUL CINQUEFOIL

(Potentilla gracilis)

YARROW

(Achillea millefolium)

CHICKWEED

(Cerastium arvense)

ELEPHANT'S HEAD

(Pedicularis groenlandica) 2

GRASSES

GRACEFUL SEDGE

(Carex praegracilis)

39

TUFTED HAIRGRASS

(Deschampsia cespitosa)

SEDGE SPP.

(Carex spp.)

HAIRY WILDRYE

(Elymus innovatus)
39

12

\section{9}

3

100

100

100

\section{ENVIRONMENTAL VARIABLES}

MOISTURE REGIME:

SUBHYGRIC

NUTRIENT REGIME:

PERMESOTROPHIC

ELEVATION:

1640(1600-1700) M

SOIL DRAINAGE:

WELL

SLOPE:

$9(1-20) \%$

ASPECT:

SOUTHWESTERLY

Forage Production

GRASS 1208

FORB 98

TOTAL 1256

SugGeSTEd GRAZING CAPACITY (HoRses) 1.1HA/AUM 


\section{A10. Bog birch/Sedge-Rough fescue \\ (Betula glandulosa/Carex spp.-Festuca scabrella)}

$\mathbf{n}=\mathbf{1}$ This community type represents the invasion of bog birch onto the rough fescue grasslands. This community type is found scattered throughout the grasslands in the Ya Ha Tinda on slightly moister sites. It also appears to be transitional to many of the forested stands in the area. This community type is very similar to the Bog birch/Rough fescue community type described by Willoughby (2001) in the Upper Foothills subregion. They felt that the lack of fire on this community type allowed bog birch cover to expand, reducing forage productivity for wildlife and domestic livestock. In one study, burning bog birch twice in 3 year intervals controlled birch growth and increased total forage production by over $40 \%$ compared to the unburned control (Bork 1990).

\section{Plant Composition Canopy Cover(\%)} Mean Range Const.

\section{SHRUBS}

BOG BIRCH

(Betula glandulosa)

SHRUBBY CINQUEFOIL

(Potentilla fruticosa)

\section{FORBS}

YARROW

(Achillea millefolium) 3

SMALL LEAVED EVERLASTING

(Antennaria parviflora) 2

CUT LEAVED ANEMONE

(Anemone multifida) 4

HEART LEAVED ALEXANDERS

(Zizia aptera)

4

OLD MAN'S WHISKERS

(Geum triflorum)

AMERICAN VETCH

(Vicia americana)

3

3

3

GRASSES

SEDGE SPP.

(Carex spp.)

ROUGH FESCUE

(Festuca scabrella)

SHEEP FESCUE

(Festuca sacimontana)

JUNEGRASS

(Koeleria macrantha)
100

100

100

100

\section{ENVIRONMENTAL VARIABLES}

MOISTURE REGIME:

MESIC

NUTRIENT REGIME:

MESOTROPHIC

ELEVATION:

$1476 \mathrm{M}$

SOIL DRAINAGE:

WELL

\section{Forage Production Kg/HA}

100

100 


\section{A11. Rough fescue-Fringed brome-Sedge (Festuca scabrella-Bromus ciliatus-Carex spp.)}

$\mathbf{n}=\mathbf{5}$ This community type represents coarse textured fluvial areas and moister south and west facing slopes. The increased moisture on these spots favours the growth of fringed brome. On the drier south and west facing slopes these grasslands are dominated by rough fescue, sedge and junegrass. The forage production on this community type tends to be slightly higher than the Rough fescue-Sedge-Junegrass dominated community type. Making this community type one of the most important foraging areas for wildlife. The rough fescue grasslands in the $\mathrm{Ya} \mathrm{Ha}$ Tinda area are extensively utilized by elk and domestic horses. It is not clear how this heavy grazing pressure has affected the species composition of these grasslands. It is likely that rough fescue cover would increase if the grazing pressure was reduced on these grasslands (Willoughby 1992).

Plant Composition Canopy Cover(\%) Mean Range Const.

SHRUBS

SHRUBBY CINQUEFOIL.

(Potentilla fruticosa)

2

$0-2$

80

FORBS

EARLY YELLOW LOCOWEED

(Oxytropis sericea) 7

SMALL LEAVED EVERLASTING

(Antennaria parviflora) 1

OLD MAN'S WHISKERS

(Geum triflorum)

ALPINE HEDYSARUM

(Hedysarum alpinum) 3

YARROW

(Achillea millefolium) 3

SHOWY LOCOWEED

(Oxytropis splendens) $2 \quad 0-6 \quad 60$

CUT LEAVED ANEMONE

(Anemone multifida)

2

$0-3 \quad 60$

\section{GRASSES}

JUNEGRASS

$\begin{array}{llll}\text { (Koeleria macrantha) } & 3 & 1-6 & 100\end{array}$

FRINGED BROME

(Bromus ciliatus) $\quad 10 \quad 2-17 \quad 100$

THREAD-LEAVED SEDGE

(Carex filifolia) $\quad 9 \quad 1-10 \quad 100$

ROUGH FESCUE

(Festuca scabrella) $\quad 8 \quad 4-11 \quad 100$

\section{ENVIRONMENTAL VARIABLES}

MOISTURE REGIME:

SUBXERIC-SUBMESIC

\section{NUTRIENT REGIME:}

MESOTROPHIC

\section{ELEVATION:}

$1640(1600-1700) \mathrm{M}$

SOIL DRAINAGE:

RAPIDLY

SLOPE:

$6(0-20) \%$

ASPECT:

SCUTH TO WESTERLY

Forage Production Kg/HA

GRASS 802(560-1006)

FORB 322(130-674)

SHRUB 82(0-350)

TOTAL 1207(804-1740)
SUGGESTED GRAZING CAPACITY(HORSES)

$1.1 \mathrm{HA} / A U M$ 


\section{A12. Rough fescue-Sedge-Junegrass (Festuca scabrella-Carex filifolia-Koeleria macrantha)}

$\mathbf{n}=\mathbf{2}$ This community type is distinguished from the other rough fescue dominated community type by the lack of fringed brome and the increased cover of junegrass. This community type tends to occupy steeper, morainal and colluvial slopes and and has a drier moisture regime than the previously described rough fescue community type. Morgantini and Russell (1983) found that the rough fescue dominated community types were the primary foraging areas for elk. As a result this community type should be rated as primary range. The rough fescue grasslands in the $\mathrm{Ya} \mathrm{Ha}$ Tinda area are extensively utilized by elk and domestic horses. It is not clear how this heavy grazing pressure has affected the species composition of these grasslands. It is likely rough fescue cover would increase if the grazing pressure was reduced on these grasslands (Willoughby 1992).

\section{Plant CoMposition Canopy Cover(\%)} MEAN RANGe CONST.

SHRUBS

SHRUBBY CINQUEFOIL

(Potentilla fruticosa)

$3 \quad 1-4 \quad 100$

FORBS

EARLY YELLOW LOCOWEED

(Oxytropis sericea) 10

WOOLY EVERLASTING

(Antennaria lanata)

OLD MAN'S WHISKERS

(Geum triflorum)

FALSE DANDELION

(Agoseris glauca)

$7-12$

100

$1 \quad 2-3 \quad 100$

6

$0-12 \quad 50$

1

$0-2$

100

\section{GRASSES}

NORTHERN WHEATGRASS

\begin{tabular}{|c|c|c|c|}
\hline (Agropyron dasystach) & & $2-3$ & 100 \\
\hline JUNEGRASS & & & \\
\hline (Koeleria macrantha) & 7 & $3-10$ & 100 \\
\hline $\begin{array}{l}\text { ROUGH FESCUE } \\
\text { (Festuca scabrella) }\end{array}$ & 13 & $7-18$ & 100 \\
\hline $\begin{array}{l}\text { THREAD LEAF SEDGE } \\
\text { (Carex filifoliaspp.) }\end{array}$ & 5 & $5-5$ & 100 \\
\hline $\begin{array}{l}\text { HAIRY WILDRYE } \\
\text { (Elymus innovatus) }\end{array}$ & 2 & $0-4$ & 50 \\
\hline
\end{tabular}

MOISTURE REGIME:

SUBXERIC

NUTRIENT REGIME:

MESOTROPHIC-SUBMESOTROPHIC

ELEVATION:

$1625(1600-1650) \mathrm{M}$

SOIL DRAINAGE:

RAPIDLY

SLOPE:

$23(10-35) \%$

ASPECT:

SOUTH TO WEST

PARENT MATERIAL:

MORAINAL, COLLUVIAL

\section{FORAGE PRODUCTION KG/HA}
GRASS 584(514-654)
FORB 228(156-300)
SHRUB 69(24-114)
TOTAL 881(834-928)

SUGGESTED GRAZING CAPACITY(HORSES) $1.5 \mathrm{HA} / \mathrm{AUM}$ 


\section{A13. Sedge-Junegrass \\ (Carex filifolia-Koeleria macrantha)}

$\mathbf{n}=\mathbf{2}$ This community type was described on the west side of the Ya Ha Tinda ranch. It is closer to the ranch buildings and therefore is more extensively utilized by horses. It was described on coarse textured fluvial areas. The parent material and ecological conditions are similar to the Rough fescue-Fringed brome-Sedge dominated community type. It appears that the heavier grazing pressure on this community type causes rough fescue to decline and allows sedge and junegrass to increase. The forage production on this community type is about half of the rough fescue dominated community types, indicating that some type of rest would benefit this grassland.

Plant Composition Canopy Cover(\%) MEAN RANGe CONST.

\section{SHRUB}

SHRUBBY CINQUEFOIL

(Potentilla fruticosa)

$\begin{array}{lll}8 & 5-9 \quad 100\end{array}$

\section{FORBS}

EARLY YELLOW LOCOWEED

(Oxytropis sericera)
THREE FLOWERED AVENS

(Geum trifolium)

CUT LEAVED ANEMONE

(Anemone multifida)

SHOWY LOCOWEED

(Oxytropis splendens)

FRINGED SAGE

(Artemisia frigida)

WHITE CAMAS

(Zigadenus elegans)

2

2

3

3

3

1

1

GRASSES

SEDGE SPP.

(Carex spp.)

KENTUCKY BLUEGRASS

(Poa pratensis)

JUNEGRASS

(Koeleria macrantha)

SHEEP FESCUE

(Festuc saximontana)

LICHEN
6

$6-6-6 \quad 100$

$3 \quad 2-4 \quad 100$

$5 \quad 4-6 \quad 100$

$3 \quad 1-4 \quad 100$

$7 \quad 1-12 \quad 100$
MOISTURE REGIME:

SUBXERIC

NUTRIENT REGIME:

SUBMESOTROPHIC

ELEVATION:

1477(1474-1480) M

SOIL DRAINAGE:

RAPIDLY

\section{Forage Production Kg/Ha}

GRASS $451(90-884)$

FORB 71(2-200)

SHRUB 5(2-10)

TOTAL 520(292-906)
SugGested GRAZING CAPACITY(HORSES)

$2.6 \mathrm{HA}$ AUM 


\section{A14. Creeping red fescue-Timothy \\ (Festuca rubra-Phleum pratense)}

$\mathbf{n}=\mathbf{2} \quad$ This community type represents spruce cutblocks that were harvested and seeded to creeping red fescue and timothy. This seeding was done in order to increase the forage supply for wintering elk and alleviate the pressure on the rough fescue dominated grasslands around the $\mathrm{Ya} \mathrm{Ha} \mathrm{Tinda} \mathrm{ranch.} \mathrm{This} \mathrm{seeding} \mathrm{has} \mathrm{increased} \mathrm{the}$ forage supply of the area, but it has been found that elk do not perfer to graze these sites. The agronomic species seeded into these cutblocks have also been found to be invasive (Gerling et al. 1996). Further range improvement should probably be done with a native seed mix.

\section{PLANT COMPOSITION CANOPY COVER(\%)} Mean Range Const.

\section{SHRUBS}

WILLOW SPP. (Salix spp.)

$2 \quad 0-2 \quad 100$

\section{FORBS}

TALL LARKSPUR (Delphinium glaucum) $\quad 1 \quad 0-2 \quad 50$

\section{FIREWEED}

(Epilobium angustifolium)2

\section{Grasses}

KENTUCKY BLUEGRASS

\section{(Poa pratensis)}

CREEPING RED FESCUE

(Festuca rubra)

HAIRY WILDRYE

(Elymus innovatus)

TIMOTHY

(Phleum pratense)

SEDGE SPP.

(Carex spp.)

$\begin{array}{lll}8 & 7-9 & 100\end{array}$

$6 \quad 1-11 \quad 100$
MOISTURE REGIME:

MESIC

NUTRIENT REGIME:

MESOTROPHIC

ELEVATION:

$$
\text { 1593( 1565-1620) M }
$$

SOIL DRAINAGE:

WELL TO IMPERFECTLY

SLOPE:

$$
40(35-45) \%
$$

Forage Production KG/HA

TOTAL 1500 


\section{MONTANE SUBREGION \\ BLAIRMORE AND MORLEY FOOTHILLS ECODISTRICTS GRASSLAND COMMUNITY TYPES}

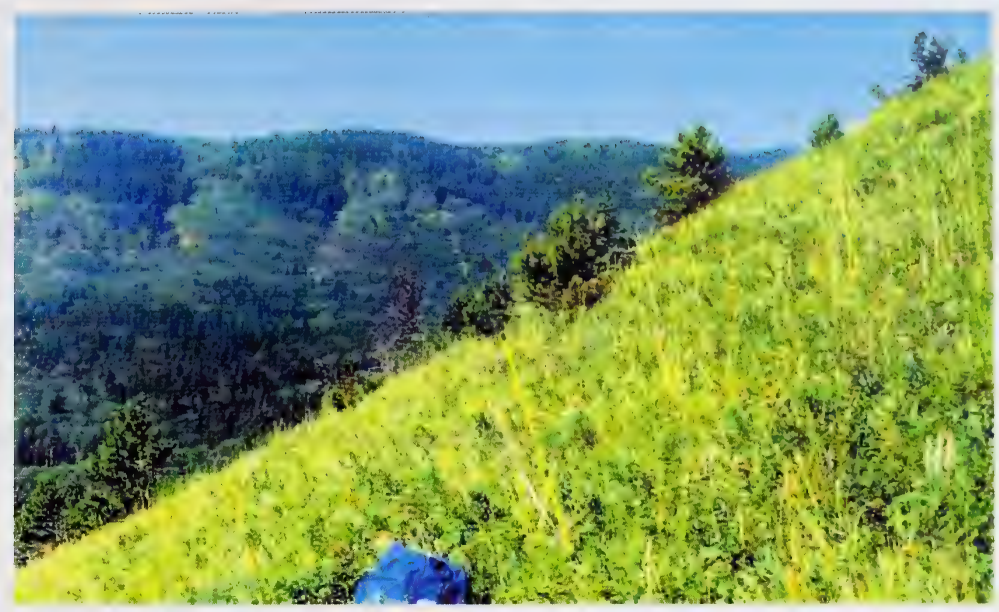

Photo 4. Blairmore Foothills ecodistrict: This represents a Rough fescue-Sedge/Bearberry grassland found on a wind-swept, steep, south-facing slope where the moisture regime is submesic to subxeric. The harsh environmental conditions favour the growth of Limber pine.

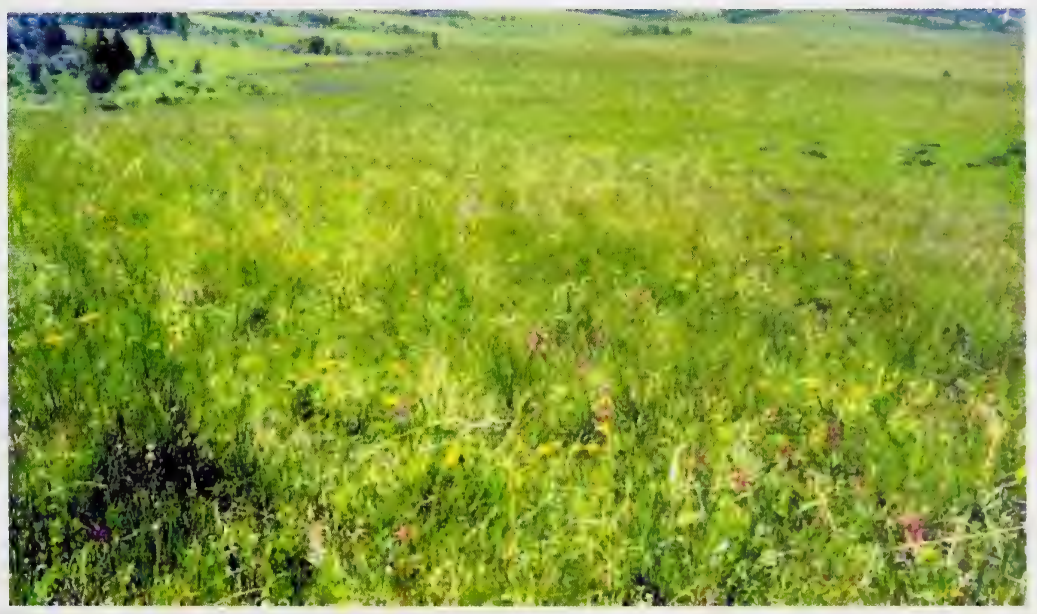

Photo 5. Blairmore Foothills ecodistrict: This is a moderately-grazed Idaho fescue-Parry oatgrass-Rough fescue grassland. This community type is highly diverse as a result of light to moderate grazing. Under long-term, heavy grazing, diversity would decline as Kentucky bluegrass and dandelion became the dominant species. 


\section{B1. Rough fescue-Idaho fescue-Parry oatgrass \\ (Festuca scabrella-Festuca idahoensis-Danthonia parryii)}

$\mathrm{n}=102$ This community appears to be the modal grassland community type on Black Chernozemic soils in the foothills of southern Alberta from an elevation of $1300 \mathrm{~m}$ up to $1900 \mathrm{~m}$ on isolated sites. Willoughby (1992), described one Rough fescue-dominated site where the species composition had not changed in over 30 years, indicating this maybe the climax community type on river terraces and south facing slopes in the Montane. Indeed Moss and Campbell (1947), found that rough fescue grows almost to the exclusion of other plants in the absence of disturbance. On rocky and gravelly slopes with shallow soils, rough fescue is replaced by Parry oatgrass and Idaho fescue. They also found Parry oatgrass and Idaho fescue increased and rough fescue declined with increased grazing pressure. Willoughby (1992), also described rough fescue and Idaho fescue dominated community types with little Parry oatgrass in the Castle area south of Blairmore. He also found that rose and shrubby cinquefoil tended to increase in cover at higher elevations in these grasslands. In this guide it was difficult and impractical to distinguish these community types. Consequently, the Rough fescue, Rough fescue-Idaho fescue and Rough fescueParry oatgrass/Shrubby cinquefoil-Rose community types listed in Willoughby (1992) are grouped into this one large community type.

\section{Plant COMPOSITION CANOPY COVER(\%) Mean Range Const}

SHRUBS

SHRUBBY CINQUEFOIL

(Potentilla fruticosa) $\quad 3 \quad 0-25 \quad 60$

\section{FORBS}

OLD MAN'S WHISKERS

(Geum triflorum)

YELLOW BEARDTONGUE

(Penstemon confertus)

Cut LeAved ANEMONE

(Anemone multifida)

WOOLY GROMWELL

(Lithosperma ruderale)

STICKY PURPLE GERANIUM

(Geranium viscosissimum)2

MOUNTAIN SHOOTING STAR

(Dodecatheon conjugens) 1

GRASSES

ROUGH FESCUE

(Festuca scabrella)

IDAHO FESCUE

(Festuca idahoensis)

PARRY OATGRASS

(Danthonia parryi)

BLUNT SEDGE

(Carex obtusata)
29

$13-61 \quad 100$

$8 \quad 0-48$

92

10

$0-27$

81

4

$0-24$

\section{ENVIRONMENTAL VARIABLES}

MOISTURE REGIME:

SUBXERIC-MESIC

NUTRIENT REGIME:

MESOTROPHIC-PERMESOTROPHIC

ELEVATION:

1587(1370-2121) M

SOIL DRAINAGE:

WELL TO MODERATELY WELL

SLOPE :

$19(2-65) \%$

ASPECT:

SOUTHERLY-WESTERLY

Forage ProduCtion (KG/HA)

GRASS 1346(304-4144)

FORB 519(0-2378)

SHRUB 98(0-924)

TOTAL 1933(810-4838)

\section{SUGGESTED GRAZING CAPACITY} $0.5 \mathrm{HA} / \mathrm{AUM}$ 


\section{B2. Idaho fescue-Parry oatgrass-Rough fescue (Festuca idahoensis-Danthonia parryi-Festuca scabrella)}

$\mathbf{n}=\mathbf{5 2}$ This community type is found upslope from the Rough fescue-Parry oatgrass-Idaho fescue community type (Figure 1) and can be dominated by Idaho fescue or Parry oatgrass. As one moves upslope to drier conditions there is a shift in species composition from rough fescue to Parry oatgrass and Idaho fescue. Under grazing pressure Parry oatgrass, Idaho fescue and rough fescue decline and upland sedge increases (Willoughby 1992). On drier sites within this community type juniper and bearberry cover can be extensive. Increased grazing pressure on the drier sites will lead to an increase in low growing forbs (little clubmoss, moss phlox) and sedges.

\section{Plant COMPOSITION CANOPY COVER(\%)} Mean Range Const.

\section{SHRUBS}

SHRUBBY CINQUEFOIL

(Potentilla fruticosa)

PRICKLY ROSE

(Rosa acicularis)

$\begin{array}{lll}2 & 0-14 & 53 \\ 2 & 0-15 & 57\end{array}$

FORBS

YARROW

(Achillea millefolium)

OLD MAN'S WHISKERS

(Geum triflorum)

SILKY PERENNIAL LUPINE

(Lupinus sericeus)

WOOLY GROMWELL

(Lithosperma ruderale)

CUT LEAVED ANEMONE

(Anemone multifida)

GRASSES

PARRY OATGRASS

(Danthonia parryi)

ROUGH FESCUE

(Festuca scabrella)

IDAHO FESCUE

(Festuca idahoensis)

BLUNT SEDGE

(Carex obtusata)

JUNEGRASS

(Koeleria macrantha)

$\begin{array}{lll}2 & 0-11 & 94 \\ 3 & 0-18 & 46 \\ 3 & 0-14 & 64 \\ 1 & 0-2 & 43 \\ 3 & 0-11 & 79\end{array}$

$17 \quad 0-51 \quad 82$

$10 \quad 0-30 \quad 96$

$15 \quad 0-63 \quad 96$

$3 \quad 0-22 \quad 22$

$3 \quad 0-18 \quad 87$
MOISTURE REGIME :

SUBXERIC-MESIC

NUTRIENT REGIME:

SUBMESOTROPHIC TO MESOTROPHIC

ELEVATION:

1558(1330-1848) M

SOIL DRAINAGE:

RAPIDLY-WELL

SLOPE:

$20(0-45) \%$

ASPECT:

SOUTHERLY

Forage Production (KG/HA)

GRASS 651(148-2026)

FORB 353(10-838)

SHRUB 55(0-248)

TOTAL 1363(594-2446)

\section{SUGGESTED GRAZING CAPACITY $0.7 \mathrm{HA} / \mathrm{AUM}$}




\section{B3. Bluebunch wheatgrass-Sedge \\ (Agropyron spicatum-Carex obtusata)}

$\mathbf{n}=\mathbf{2 7}$ Bluebunch wheatgrass dominated sites are found on well-drained, south facing-slopes in the Montane subregion throughout southern Alberta (Strong 1992). This dominant species is abundant in the interior of southern British Columbia, where it is codominant with big sagebrush (Artemisia tridentata) at lower elevations and rough fescue at higher elevations (Tisdale 1947). Increased grazing pressure on the drier sites leads to a decline in bluebunch wheatgrass and allows low growing forbs and sedge species to increase. On sites with big sagebrush in British Columbia bluebunch wheatgrass decreases and big sagebrush will increase with increased grazing pressure (Tisdale 1947). Forage production on this type can vary from $700 \mathrm{~kg} / \mathrm{ha}$ on dry sites to over $2000 \mathrm{~kg} / \mathrm{ha}$ on moister sites.

PLANT COMPOSITION CANOPY COVER(\%) MEAN RANGe CONST.

SHRUBS

SASKATOON

(Amelanchier alnifolia) $8 \quad 0-31 \quad 92$

WESTERN SNOWBERRY

(Symphoricarpos occidentalis) $8 \quad 0-41 \quad 63$

\section{FORBS}

YELLOW BEARDSTONGUE

(Penstemon confertus)

SILKY PERENNIAL LUPINE

(Lupinus sericeus)

COMMON STRAWBERRY

(Fragaria virginiana)

BEARBERRY

(Arctostaphylos uva-ursi)5

FRINGED SAGE

(Artemisia frigida)

3

GraSSES

JUNEGRASS

(Koeleria macrantha)

SLENDER WHEATGRASS

(Agropyron trachycaulum) 1

BLUNT SEDGE

(Carex obtusata) 3

(Agropyron spicatum) 17

ROUGH FESCUE

(Festuca scabrella)
$0-24 \quad 44$

$0-28 \quad 63$

$0-17 \quad 33$

$0-21 \quad 41$

$0-12 \quad 48$

$0-22 \quad 92$

$0-17 \quad 37$

$0-21 \quad 26$

4-43 100

$0-29 \quad 73$

\section{ENVIRONMENTAL VARIABLES}

MOISTURE REGIME:

XERIC-SUBMESIC

NUTRIENT REGIME:

SUBMESOTROPHIC-MESOTROPHIC

ELEVATION:

1630(1394-1848) M

SOIL DRAINAGE:

RAPIDLY TO VERY RAPIDLY

SLOPE:

$46(0-65) \%$

ASPECT:

SOUTH TO WESTERLY

Forage Production(KG\HA)

GRASS 760(396-1178)

FORB $457(0-1170)$

SHRUB 238(0-626)

TOTAL 1456(612-2660)

SUGGESTED GRAZING CAPACITY $0.6 \mathrm{HA} / \mathrm{AUM}$ 


\section{B4. Rough fescue-Sedge/Bearberry \\ (Festuca scabrella-Carex obtusata/Arctostaphylos uva-ursi)}

$\mathbf{n = 4 8}$ This community appears to be characteristic of dry grass meadows on hilltops throughout the Montane subregion. It is similar to the Rough fescue-Sedge community type described by Willoughby (1992) on hilltops in the Porcupine Hills. The shallow poorly developed soils appear to favour rough fescue, slender wheatgrass and sedge over Parry oatgrass. This community is drier than the Rough fescue grasslands characteristic of lower slope positions, but is moister than the bluebunch wheatgrass plant community that is associated with dry southerly slopes. This community type can be invaded by aspen to form the Aspen/Saskatoon/Sedge, P1/Bearberry-Juniper or $\mathrm{Fd} / \mathrm{Hairy}$ wildrye community types. The transition community between the forest and grassland may resemble the Pinegrass-Hairy wildrye or Snowberry-Rose-Saskatoon/Bearberry community types.

\section{Plant Composition Canopy Cover(\%)} MEAN RANGe CONST.

SHRUBS

PRICKLY ROSE

(Rosa acicularis)

CREEPING JUNIPER

(Juniprus horizontalis) $2 \quad 0-24 \quad 21$

SNOWBERRY

(Symphoricarpos occidentalis) $1 \quad 0-6 \quad 29$

SASKATOON

(Amelanchier alnifolia) $\quad 3 \quad 0-16 \quad 69$

FORBS

BEARBERRY

(Arctostaphylos uva-ursi) $33 \quad 0-77 \quad 97$

FRINGED SAGE

$\begin{array}{llll}\text { (Artemisia frigida) } & 1 & 0-5 & 11\end{array}$

MOSS PHLOX

(Phlox hoodii)

$1 \quad 0-8$

CUT LEAVED ANEMONE

(Anemone multifida)

STRAWBERRY

(Fragaria virginiana)

3

$0-21$

90

$0-19$

73

GRASSES

ROUGH FESCUE

(Festuca scabrella)

SLENDER WHEATGRASS

(Agropyron trachycaulum) 3

JUNEGRASS

(Koeleria macrantha)

BLUNT SEDGE

(Carex obtusata)

IDAHO FESCUE

$\begin{array}{llll}\text { (Festuca idahoensis) } & 4 & 0-18 \quad 77\end{array}$

PARRY OATGRASS

(Danthonia parryi)
$24 \quad 5-54 \quad 100$

$0-14 \quad 80$

$0-21 \quad 42$

$0-37 \quad 58$
$0-34 \quad 40$

\section{ENVIRONMENTAL VARIABLES}

MOISTURE REGIME:

XERIC-MESIC

NUTRIENT REGIME:

SUBMESOTROPHIC-MESOTROPHIC

ELEVATION:

1669(1341-2134)M

SOIL DRAINAGE:

RAPIDLY TO WELL

SLOPE:

$28(7-58) \%$

ASPECT:

SOUTH TO WEST

Forage Production(KG/Ha)

GRASS 798(0-2184)

FORB 499(0-1684)

SHRUB $617(0-2972)$

TOTAL $1540(236-3478)$

\section{SUGGESTED GRAZING CAPACITY} 0.6 HA/AUM 


\section{B5. Big sagebrush/Bluebunch wheatgrass-Sedge (Artemisia tridentata/Agropyron spicatum-Carex spp.)}

$\mathrm{n}=4$ This community type is rare in Alberta and is isolated on gravelly south facing slopes in the Montane subregion south of Blairmore. This community type is similar to the Pacific Northwest Bunchgrass type described by Tisdale (1982) in Washington and British Columbia. The big sagebrush, bluebunch wheatgrass community types found in these areas are located on Dark Brown and Dk Gray Chernozemic soils, with glacial till parent material (Green and van Ryswyk 1982). Tisdale (1982), found that there is little known about the environmental factors which determine the presence of sagebrush-grass versus true grassland. Therefore, it is not clear why these south facing slopes are dominated by sagebrush and not a bluebunch wheatgrass community type. It is known that increased grazing pressure on a Big sagebrush/Bluebunch wheatgrass in British Columbia will allow big sagebrush to increase in cover, but heavy grazing pressure does not seem to be a factor in the formation of this community type in Alberta.

\section{PLANT COMPOSITION CANOPY COVER(\%)} MEAN RANGE CONST.

\section{SHRUBS}

BIG SAGEBRUSH

(Artemisia tridentata) $\quad 21 \quad 7-45 \quad 100$

FORBS

LITTLE CLUBMOSS

(Selaginella densa)

$5 \quad 0-15 \quad 75$

BEARBERRY

(Arctostaphylos uva-ursi) 22

SMALL-LEAVED EVERLASTING

(Antennaria parviflora) 1

NODDING ONION

(Allium cernuum)

STICKY ALUMROOT

(Heuchera cylindrica)

SILKY PERENNIAL LUPINE

(Lupinus sericeus)

1

$0-58 \quad 75$

$1-2 \quad 100$

$0-1 \quad 75$

$0-4 \quad 25$

$2 \quad 1-4 \quad 100$

\section{GRASSES}

NORTHERN WHEATGRASS

(Agropyron dasystachyum )1

BLUEBUNCH WHEATGRASS

(Agropyron spicatum)

IDAHO FESCUE

(Festuca idahoensis) $\quad 8$

JUNEGRASS

(Koeleria macrantha)
BLUNT SEDGE

(Carex obtusata)
$8 \quad 6-13 \quad 75$

$3 \quad 2-4 \quad 75$

$1 \quad 0-1 \quad 25$

$5 \quad 2-13 \quad 75$

\section{ENVIRONMENTAL VARIABLES}

MOISTURE REGIME :

SUBXERIC-MESIC

NUTRIENT REGIME :

SUBMESOTROPHIC

ELEVATION:

$$
1550(1470-1680) \mathrm{M}
$$

SOIL DRAINAGE :

RAPIDLY TO WELL

SLOPE:

39(35-40)\%

ASPECT:

SOUTH AND WEST

Forage ProduCtion (KG/HA)

GRASS 180

FORB 250

SHRUB 276

TOTAL 706

SugGeStEd GRAZING CAPACITY 1.3 HA/AUM 


\section{B6. Snowberry-Rose-Saskatoon/Bearberry}

(Symphoricarpos occidentalis-Rosa acicularis-Amelanchier alnifolia/Arctostaphylos uvaursi)

$\mathbf{n = 5 8}$ This community type represents the ecotone between rough fescue dominated grasslands and Douglas fir and lodgepole pine dominated forests on dry south facing slopes. The presence of shrubs (saskatoon, rose, snowberry) and the grass species (hairy wildrye, pinegrass) indicate the transition from rough fescue grasslands to a forested community type. This community type appears to occur at higher elevations $(>1500 \mathrm{~m})$ and may reflect the dominance of trees at the higher altitudes. Forage production declines rapidly moving from the grassland into the forests. This community type has half the production $(1100 \mathrm{~kg} / \mathrm{ha})$ of rough fescue dominated grasslands $(2200$ $\mathrm{kg} / \mathrm{ha}$ ). The increase in tree canopy cover results in a further decline in forage production to approximately 600 $\mathrm{kg} / \mathrm{ha}$.

Plant COMPOSITION CANOPY COVER(\%) Mean Range Const.

TREES

ASPEN

(Populus tremuloides)

SHRUBS

SHRUBBY CINQUEFOIL

(Potentilla fruticosa) $\quad 2 \quad 0-21 \quad 42$

SNOWBERRY

(Symphoricarpos occidentalis)3 $\quad 0-38 \quad 54$

SASKATOON

(Amelanchier alnifolia) $6 \quad 0-52 \quad 71$

PRAIRIE ROSE, PRICKLY ROSE

(Rosa arkansana, $R$. acicularis) 5

FORBS

BEARBERRY

(Arctostaphylos uva-ursi) 13

SILKY PERENNIAL LUPINE

(Lupinus sericeus)

CUT LEAVED ANEMONE

(Anemone multifida) $\quad 2 \quad 0-10 \quad 70$

SMOOTH ASTER

(Aster laevis)

STRAWBERRY

(Fragaria virginiana) $\quad 4 \quad 0-28 \quad 58$

GRASSES

ROUGH FESCUE

(Festuca scabrella)

JUNEGRASS

(Koeleria macrantha)

BLUNT SEDGE

(Carex obtusata)

HAIRY WILDRYE

(Elymus innovatus)

PINEGRASS

\section{(Calamagrostis rubescens) $4 \quad 0-29 \quad 44$}

\section{ENVIRONMENTAL VARIABLES}

MOISTURE REGIME :

XERIC-SUBMESIC

NUTRIENT REGIME:

SUBMESOTROPHIC-MESOTROPHIC

ELEVATION:

1598(1350-1981) M

SOIL DRAINAGE :

VERY RAPIDLY TO WELL

SLOPE (RANGE):

$32(0-73) \%$

ASPECT:SOUTHERLY

Forage Production (KG/HA)

GRASS 724(188-1594)

FORB 419(0-1466)

SHRUB $161(0-416)$

TOTAL $1245(600-2706)$

\section{SUGGESTED GRAZING CAPACITY}

0.7 HAAUM 


\section{B7. Pinegrass-Hairy wildrye/Strawberry (Calamagrostis rubescens-Elymus innovatus/Fragaria virginiana)}

$\mathbf{n = 1 1}$ This community type represents the transition from grassland to forest on moist sites with northerly aspects. It appears this community occurs in areas that have some seepage throughout the growing season. There is usually high forb cover on these sites with strawberry, showy aster, american vetch, peavine and silky perennial lupine being common. Pinegrass and hairy wildrye are the common grass species in the understory of conifer and deciduous stands and their dominance in this community type may indicate a transition to a forested community. The high moisture content of these sites allows for production of over $2000 \mathrm{~kg} / \mathrm{ha}$.

\section{Plant COMPOSITION CANOPY COVER(\%)}

\section{MEAN RANGE CONST.}

TREES

ASPEN

(Populus tremuloides) $\quad \mathrm{T} \quad 0-1 \quad 9$

\section{SHRUBS}

\section{DWARF BILBERRY}

(Vaccinium caespitosum) 1

SNOWBERRY

(Symphoricarpos occidentalis)2 $\quad 0-6 \quad 36$

\begin{tabular}{|c|c|c|}
\hline acicularis) & 2 & $0-5$ \\
\hline MEADOWSWEET & & \\
\hline aea betulifolia) & 2 & $0-10$ \\
\hline
\end{tabular}

\section{FORBS}

STRAWBERRY

\begin{tabular}{llll}
$\begin{array}{l}\text { (Fragaria virginiana) } \\
\text { YELLOW PEAVINE }\end{array}$ & 13 & $1-32$ & 100 \\
$\begin{array}{l}\text { (Lathyrus ochroleucus) } \\
\begin{array}{l}\text { SILKY PERENNIAL LUPINE } \\
\text { (Lupinus sericeus) }\end{array}\end{array}$ & 4 & $0-13$ & 91 \\
$\begin{array}{c}\text { SHOWY ASTER } \\
\text { (Aster conspicuus) }\end{array}$ & 5 & $0-20$ & 55 \\
\hline
\end{tabular}

\section{GRASSES}

PINEGRASS

(Calamagrostis rubescens)23 $3-66 \quad 100$

HAIRY WILD RYE

(Elymus innovatus) $\quad 7 \quad 0-48 \quad 36$

NORTHERN AWNLESS BROME

(Bromus pumpellianus) 1

$0-3 \quad 9$

\section{ENVIRONMENTAL VARIABLES}

MOISTURE RECIME :

MESIC-SUBHYGRIC

NUTRIENT REGIME :

MESOTROPHIC-PERMESOTROPHIC

ELEVATION:

1514(1364-1640) M

SOIL DRAINAGE:

WELL TO MODERATELy WELL

SLOPE:

$25(2-46) \%$

ASPECT:

NORTHERLY, WEST, EAST

Forage Production (KG/HA)

GRASS 1487(1058-1916)

FORB 1003(858-1148)

TOTAL 2260(1800-3064)

\section{SUGGESTED GRAZING CAPACITY}

0.4 HA/AUM 


\section{B8.Douglas fir/Idaho fescue-Rough fescue (Pseudotsuga menziesii/Festuca idahoensis-Festuca scabrella)}

$\mathbf{n}=\mathbf{5}$ This community type represents the transition from grassland to a Douglas fir dominated forest. The factors responsible for the differences between forest and grassland maybe climatic, with cooler and moister conditions favouring forest, it could be edaphic with grasslands found on drier and shallower soils or lack of disturbance from fire which favours the growth of trees. Extensive overlap of the forests and grassland will occur in the Montane because of the variable soils and topography.

\section{Plant Composition Canopy Cover(\%) MEAN RANGE CONST.}

TREES

DOUGLAS FIR

$\begin{array}{llll}\text { (Pseudotsuga menziesii) } & 14 & 1-18 \quad 100\end{array}$

LODGEPOLE PINE

(Pinus contorta)

SHRUBS

SASKATOON

(Amelanchier alnifolia)

WHITE MEADOWSWEET

(Spiraea betulifolia)

$4 \quad 0-15 \quad 40$

FORBS

BEARBERRY

(Arctostaphylos uva-ursi) 10

NORTHERN BEDSTRAW

(Galium boreale)

WILD STRAWBERRY

(Fragaria virginiana) 4

SILKY PERENNIAL LUPINE

(Lupinus sericeus) 4

BALSAMROOT

(Balsamorhiza sagittata) 2

GRASSES

IDAHO FESCUE

$\begin{array}{llll}\text { (Festuca idahoensis) } & 26 & 1-60 & 100\end{array}$

ROUGH FESCUE

(Festuca scabrella) $\quad 26 \quad 13-60 \quad 100$

PINEGRASS

(Calamagrostis rubescens) 1
$0-32 \quad 80$

$1-2 \quad 100$

$1-5 \quad 100$

$0-10 \quad 80$

$0-4 \quad 60$

$0-2 \quad 60$

\section{ENVIRONMENTAL VARIABLES}

MOISTURE REGIME:

SUBMESIC

NUTRIENT REGIME: MESOTROPHIC

ELEVATION: $1562(1554-1710) \mathrm{M}$

SOIL DRAINAGE: WELL

SLOPE: $14(0-30) \%$

ASPECT:

SOUTHWEST

Forage Production(KG/HA)

GRASS 565(320-810)

FORB 238(180-296)

SHRUB 1592(1568-1616)

TOTAL 2395(2232-2558)

\section{SUGGESTED GRAZING CAPACITY} $0.8 \mathrm{HA} / \mathrm{AUM}$ 


\section{B9.Douglas fir/Idaho fescue-Sandberg bluegrass (Pseudotsuga menziesii/Festuca idahoensis-Poa sandbergii)}

$\mathbf{n}=\mathbf{1}$ This community type is similar to the Douglas fir/Idaho fescue-Rough fescue community type and represents the transition from grassland to forest, but this type is drier and has shallower soils than the Douglas fir/Idaho fescue-Rough fescue community type. Little clubmoss, fringed sage, Sandberg bluegrass and junegrass are all well adapted to dry, rapidly drained sites. Johnston (1981), described a Sandberg bluegrass/Bluebunch wheatgrass type on dry sites with extremely shallow soils in Oregon and Tisdale (1982) described Sandberg bluegrass on dry sites with fine textured soils in British Columbia. It is also possible that increased grazing pressure may also account for the high cover of Sandberg bluegrass. Mueggler and Stewart (1980), found Sandberg bluegrass increased with grazing pressure on dry grasslands in Montana.

\section{Plant COMPOSITION CANOPY COVER(\%) \\ Mean Range Const.}

TREES

DOUGLAS FIR

(Pseudotsuga menziesii) 5

\section{SHRUBS}

CREEPING JUNIPER

(Juniperus communis)

WHITE MEADOWSWEET

(Spiraea betulifolia)

1

2

\section{FORBS}

\section{LITTLE CLUBMOSS}

(Selaginella densa)

DANDELION

(Taraxacum offincinale) 3

CUT LEAVED ANEMONE

(Anemone multifida)

BALSAMROOT

(Balsamorhiza sagitata)

GRASSES

IDAHO FESCUE

(Festuca idahoensis)

SANDBERG BLUEGRASS

(Poa sandbergii)

JUNEGRASS

(Koeleria macrantha) 10

BLUEBUNCH WHEATGRASS

(Agropyron spicatum)
100

100

100

100

100

100

100

FORAGE Production (KG/HA)

Total $\quad 1750 *$ Estimate

MOISTURE REGIME:

SUBXERIC

NUTRIENT REGIME:

MESOTROPHIC

ELEVATION:

$1493 \mathrm{M}$

SOIL DRAINAGE

WELL

SLOPE:

$33 \%$

ASPECT:

SOUTHWEST

$0.5 \mathrm{HA} / \mathrm{AUM}$

SUGGESTED GRAZING CAPACITY 


\section{B10. Aw/Strawberry/Rough fescue \\ (Populus tremuloides/Fragaria virginiana/Festuca scabrella)}

$\mathbf{n}=2$ This community type represents the transition from a rough fescue dominated grassland to an aspen dominated forest. Aspen has invaded onto the grassland and the species composition of the understory is slowly succeeding to species characteristic of aspen stands such as strawberry and slender wheatgrass.

This community type is much moister than the Douglas fir transition forests previously described. Aspen favors the moist draws and north-facing slopes throughout the foothills of southern Alberta. As one moves west into the mountains and the Subalpine subregion, aspen tends to grow very poorly, and the aspen stands are characterized by stunted, twisted trees that have low vigour. Forage production on the grasslands declines rapidly when aspen invades; from a high of $2000 \mathrm{~kg} / \mathrm{ha}$ to a low of $1000 \mathrm{~kg} / \mathrm{ha}$.

\section{Plant COMPOSITION CANopy COVER(\%)} MEAN RANGe Const.

TREES

ASPEN

$$
\text { (Populus tremuloides) }
$$$$
4
$$$$
1-5
$$

\section{FORBS}

STRAWBERRY

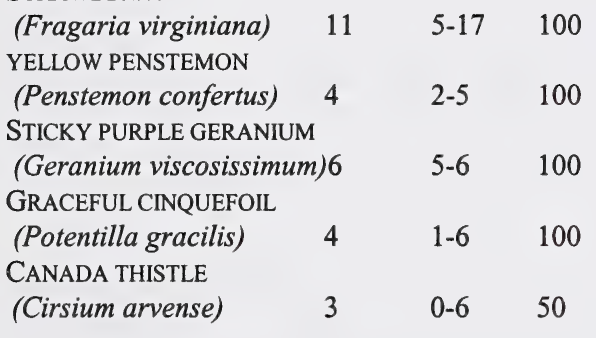

\section{GraSSES}

ROUGH FESCUE

$\begin{array}{llll}\text { (Festuca scabrella) } \quad 27 & 24-29 & 100\end{array}$

SLENDER WHEATGRASS

(Agropyron trachycaulum) 5

SEDGE SPP.

(Carex spp.)

PINEGRASS

(Calamagrostis rubescens)6

4-5 $\quad 100$

$1-4 \quad 100$

$0-11 \quad 50$

\section{ENVIRONMENTAL VARIABLES}

MOISTURE REGIME:

MESIC-SUBHYGRIC

NUTRIENT REGIME:

PERMESOTROPHIC

ELEVATION:

1524(1463-1585) M

SOIL DRAINAGE:

MODERATELY WELL

SLOPE:

$11(10-12)$

ASPECT:

SOUTH AND EAST

Forage Production (KG/HA)
GRASS $\quad 1170$

FORB $\quad 1206$

TOTAL 2376

\section{SUGGESTED GRAZING CAPACITY $0.4 \mathrm{HA} / \mathrm{AUM}$}




\section{B11. Thimbleberry \\ (Rubus parviflorus)}

$\mathrm{n}=3 \quad$ This community type is characteristic of nutrient-rich seepage areas throughout the Montane. This community is very similar to the $\mathrm{Aw}-\mathrm{Pb} / \mathrm{Thimbleberry}$ and Lodgepole pine/Thimbleberry community types described later in the guide, but it is not as successional advanced.

Forage production of this community type is very high because of the high moisture and nutrient content of the soil, but the thick cover of thimbleberry which is generally unpalatable to livestock at proper stocking levels limits access. As a result this community type would be rated as non-use range.

\section{Plant Composition Canopy Cover $(\%)$ MEAN RANGE CONST.}

SHRUBS

THIMBLEBERRY

(Rubus parviflorus) $\quad 58 \quad 52-63 \quad 100$

\section{FORBS}

STRAWBERRY

$\begin{array}{llll}\text { (Fragaria virginiana) } & 10 & 2-14 & 100\end{array}$

LINDLEY'S ASTER

(Aster ciliolatus)

SHOWY ASTER

(Aster conspicuus)

FIREWEED

(Epilobium angustifolium) 4

BANEBERRY

(Actaea rubra)

$3 \quad 0-10$

\section{GRASSES}

PINEGRASS

(Calamagrostis rubescens) 9

FOWL BLUEGRASS

(Poa palustris)

FRINGED BROME

(Bromus ciliatus)
3-4 100

$0-10 \quad 33$

$6 \quad 1-9 \quad 100$

$7 \quad 4-10 \quad 100$

$0-26 \quad 33$

$1-2 \quad 100$

$0-1 \quad 33$

\section{ENVIRONMENTAL VARIABLES}

MOISTURE REGIME: SUBHYGRIC

NUTRIENT REGIME:

PERMESOTROPHIC

ELEVATION:

1640(1500-1860) M

SOIL DRAINAGE:

WELL TO MODERATELY WELL

SLOPE:

$35(10-50) \%$

ASPECT:

VARIABLE

Forage Production (KG/HA)

GRASS 2190

FORB 256

SHRUB 186

TOTAL 2632

SUGGESTED GRAZING CAPACITY

$0.7 \mathrm{HA} / \mathrm{AUM}$ 


\section{B12. Beaked-Water sedge \\ (Carex rostrata, C. aquatilis)}

$\mathbf{n}=\mathbf{8}$ This community type is found in all subregions of Alberta. Wet conditions and periodic flooding result in the formation of sedge meadows. Bog birch and willow will invade into the drier edges of these meadows to form the Willow/Sedge and Bog birch /Sedge community types.

These community types are quite productive producing nearly $2000 \mathrm{~kg} / \mathrm{ha}$ of forage, but the high water table in the spring and summer when these meadows are most palatable limits livestock use. A study in the Yukon found that crude protein on these meadows declined from a high of $10 \%$ in May to less than $5 \%$ in September (Bailey et al. 1992). As a result, these meadows would be rated as secondary or non-use range.

\section{Plant Composition Canopy Cover(\%)}

SHRUBS

MEAN RANGE CONST.

WILLOW SPP.

(Salix spp.)

$1 \quad 0-2 \quad 63$

FORBS

PURPLE AVENS

(Geum rivale)

SMOOTH ASTER

(Aster laevis)

SWAMP HORSETAIL

(Equisetum fluviatile) $\quad 1 \quad 0-11 \quad 13$

FIREWEED

(Epilobium angustifolium) $1 \quad 0-3 \quad 25$

GRASSES

BEAKED SEDGE

(Carex rostrata)

$\begin{array}{lll}53 & 0-97 \quad 88\end{array}$

WATER SEDGE

(Carex aquatilis)

$19 \quad 0-70 \quad 50$

BALITIC RUSH

(Juncus baliticus) $4 \quad 0-21 \quad 25$

MARSH REEDGRASS

(Calamagrostis canadensis) $3 \quad 0-17 \quad 50$

\section{ENVIRONMENTAL VARIABLES}

MOISTURE REGIME:

HYGRIC-SUBHYDRIC

NUTRIENT REGIME:

PERMESOTROPHIC

ELEVATION:

1447( 1400-1500) M

SOIL DRAINAGE:

IMPEKFECTLY, POORLY

SLOPE:

$1 \%$

ASPECT:

NORTHERLY

Forage Production (KG/HA)

GRASS 2298

FORB 608

TOTAL 2906

$0.3 \mathrm{HA} / \mathrm{AUM}$ 


\section{B12a. Awned sedge \\ (Carex atherodes)}

$\mathbf{n = 3}$ This community type is found in all subregions of Alberta. Wet conditions and periodic flooding result in the formation of sedge meadows. Bog birch and willow will invade into the drier edges of these meadows to form the Willow/Sedge and Bog birch /Sedge dominated community types. Thompson and Hansen (2002) described this community on the eastern edges of the Montane subregion. They found this community in lentic situations around depressional wetlands, sloughs, potholes on sites that were generally more alkaline than the Beaked and Water Sedge dominated meadows. Willoughby (2001) has found this sedge species to be very palatable to livestock in the Upper Foothills subregion. If the sites dry out they can be extensively utilized by livestock.

These community types are quite productive producing nearly $2000 \mathrm{~kg} / \mathrm{ha}$ of forage, but the high water table in the spring and summer when these meadows are most palatable limits livestock use. A study in the Yukon found that crude protein on these meadows declined from a high of $10 \%$ in May to less than $5 \%$ in September (Bailey et al. 1992).

\section{PLANT COMPOSITION CANOPY COVER(\%) MEAN RANGE CONST.}

\section{FORBS}

MINT

$\begin{array}{llll}\text { (Mentha arvensis) } & 1 & 0-1 & 33 \\ \begin{array}{l}\text { DocK } \\ \text { (Rumex occidentalis) }\end{array} & 1 & 0-1 & 33\end{array}$

\section{GRASSES}

BEAKED SEDGE

(Carex rostrata)

WATER SEDGE

(Carex aquatilis)

AWNED SEDGE

(Carex atherodes)

$\begin{array}{lll}1 & 0-1 & 33 \\ 1 & 0-1 & 33\end{array}$

\section{ENVIRONMENTAL VARIABLES}

MOISTURE REGIME:

HYGRIC-SUBHYDRIC

NUTRIENT REGIME:

PERMESOTROPHIC

ELEVATION:

1267(1221-1363) M

SOIL DRAINAGE:

IMPERFECTLY, POORLY

SLOPE:

$1 \%$

ASPECT:

VARIABLE

FORAGE PRODUCTION (KG/HA)

GRASS 2000

FORB $\quad 150$

TOTAL 2150

\section{SUGGESTED GRAZING CAPACITY} $0.4 \mathrm{HA} / \mathrm{AUM}$ 


\section{B13. Tufted hairgrass-Baltic rush \\ (Deschampsia cespitosa-Juncus baliticus}

$\mathbf{n}=\mathbf{2}$ This community type is very similar to the tufted hairgrass-dominated communities described in the Upper foothills and Subalpine subregions of northern Alberta (Willoughby 2001) and may indicate the transition from the Montane to the Subalpine subregion in southern Alberta. This community is located on moist sites that are better drained and slightly drier than the pure sedge meadows. When this community is protected from grazing and fire for $25-40$ years willow and bog birch expand and tufted hairgrass and sedge decline. The decline in graminoid cover causes a decline in available forage production.

\section{PLANT COMPOSITION CANOPY}

\section{COVER(\%)}

\section{SHRUBS}

SHRUBBY CINQUEFOIL

(Potentilla fruticosa)

\section{MEAN}

Range Const.

19

0-19 50

\section{FORBS}

OLD MAN'S WHISKERS

(Geum triflorum)

$11 \quad 0-21 \quad 50$

SMOOTH-LEAVED CINQUEFOIL

(Potentilla diversifolia) 10

YELLOW BEARDSTONGUE

(Penstemon confertus)

\section{2}

\section{GRASSES}

TUFTED HAIRGRASS

(Deschampsia cespitosa) 52

CREEPING WIRE RUSH

(Eleocharis palustris)

BALTIC RUSH

(Juncus baliticus)

THREE SQUARE RUSH

(Scirpus pungens)

$\begin{array}{lll}52 & 24-80 & 100 \\ 10 & 0-20 & 50 \\ 15 & 3-26 & 100 \\ 10 & 0-20 & 50\end{array}$

\section{ENVIRONMENTAL VARIABLES}

MOISTURE REGIME:

SUBHYGRIC

NUTRIENT REGIME:

PERMESOTROPHIC

ELEVATION:

1497(1485-1509) M

SOIL DRAINAGE:

POORLY

\section{Forage Production (KG/HA)}

$\begin{array}{ll}\text { GRASS } & 2238 \\ \text { FORB } & 239 \\ \text { SHRUB } & 170 \\ \text { TOTAL } & 2646\end{array}$

\section{SUGGESTED GRAZING CAPACITY}

$0.3 \mathrm{HA} / \mathrm{AUM}$ 


\section{B13a. Baltic rush \\ (Juncus balticus)}

$\mathbf{n}=\mathbf{1}$ This community type is a grazing disclimax of the tufted hairgrass or sedge dominated communities (Thompson and Hansen 2002). Baltic rush is generally unpalatable to livestock and will increase with an increase in grazing pressure. The presence of this community type would indicate livestock distribution problems on the disposition and some type of rest rotational grazing system is needed to allow this community type to recover.

\section{Plant Composition Canopy Cover(\%) MEAN RANGe CONST.}

\section{FORBS}

WATER SMARTWEED

(Polygonum amphibium) $3 \quad 100$

\section{GRASSES}

TUFTED HAIRGRASS

(Deschampsia cespitosa) $3 \quad$ - $\quad 100$

MARSH REEDGRASS

(Calamagrostis canadensis)1 - 100

BALTIC RUSH

(Juncus baliticus) $\quad 98 \quad$ - $\quad 100$

\section{ENVIRONMENTAL VARIABLES}

MOISTURE REGIME:

SUBHYGRIC

NUTRIENT REGIME:

PERMESOTROPHIC

ELEVATION:

$1221 \mathrm{M}$

SOIL DRAINAGE:

POORLY

Forage Production (KG/HA)

TOTAL $1250 *$ ESTIMATE

SUGGESTED GRAZING CAPACITY

NON-USE 


\section{B14. Forb meadows \\ (Aster ciliolatus, Monarda fistulosa,Smilacina stellata)}

$\mathbf{n}=\mathbf{2}$ This community type represents small isolated forest openings that are dominated by forbs. The sites tend to be moist, moderately well drained and probably have some nutrient seepage at some time in the year. These meadows can be dominated by Lindley's aster, wild bergamont, or star flowered solomon's seal. The grass layer is generally poorly developed which makes this community type hard to group with any of the grassland community types.

The forage production of this community type is generally quite high because of the higher moisture and nutrient content of the soil, but the areas are so small and isolated they contribute little to the overall carrying capacity of a disposition.

\section{Plant Composition CANopy Cover(\%)} MEAN RANGE CONST.

\section{FORBS}

STRAWBERRY

$\begin{array}{llll}\text { (Fragaria virginiana) } & 5 & 1-8 & 100\end{array}$

STAR FLOWERED SOLOMON'S SEAL

(Smilacina stellata) $6 \quad 0-12 \quad 50$

WILD BERGAMONT

(Monarda fistulosa) $\quad 15 \quad 0-30 \quad 50$

LINDLEY'S ASTER

(Aster ciliolatus)

YELLOW PEAVINE

(Lathyrus ochroleucus) $3 \quad 0-6 \quad 50$

YELLOW COLUMBINE

(Aquilegia flavescens) $\quad 4 \quad 0-8 \quad 50$

\section{Grasses}

ROUGH FESCUE

(Festuca scabrella) $5 \quad 0-10 \quad 50$

IDAHO FESCUE

(Festuca idahoensis) $\quad 6 \quad 5-6 \quad 100$

PARRY OATGRASS

(Danthonia parryi)

$5 \quad 0-9 \quad 50$

SLENDER WHEATGRASS

(Agropyron trachycaulum) 3

\section{ENVIRONMENTAL VARIABLES}

MOISTURE REGIME:

MESIC-SUBHYGRIC

NUTRIENT REGIME:

MESOTROPHIC-PERMESOTROPHIC

ELEVATION:

1565(1450-1680)M

SOIL DRAINAGE:

WELL

SLOPE:

$22(2-40) \%$

Forage Production (KG/HA)

GRASS 824

FORB $\quad 146$

SHRUB 292

TOTAL 1262

\section{SUGGESTED GRAZING CAPACITY}

$0.7 \mathrm{HA} / \mathrm{AUM}$ 


\section{B15. Rough fescue-Hairy wildrye \\ (Festuca scabrella-Elymus innovatus)}

$\mathbf{n}=2$ This community type was described on the east slopes of the Livingstone range and appears to represent a transitional community from the lower Montane subregion to the higher Subalpine region. Indeed Willoughby(1999) described a Rough fescue-Hairy wildrye community type in the southern subalpine. They felt that as one moved upslope there would be a shift in codominance of sedge to hairy wildrye and an increase in cover of bearberry and juniper. Corns and Achuff (1982), described hairy wildrye dominated community types on south facing slopes in the more northern ecodistricts of the subalpine. They felt these grasslands occurred on areas with frequent snow avalanching. It is possible that this community type is associated with deeper snow accumulation than the other rough fescue dominated types.

\section{Plant COMPOSITION CANOPY COVER(\%)} MEAN RANGE CONST.

\section{SHRUBS}

SHRUBBY CINQUEFOIL

\section{(Potentilla fruticosa)}

PRICKLY ROSE

(Rosa acicularis)

$7 \quad 0-13 \quad 50$

$2 \quad 1-2 \quad 100$

\section{FORBS}

STRAWBERRY

(Fragaria virginiana)

OLD MAN'S WHISKERS

(Geum triflorum)

YELLOW HEDYSARUM

(Hedysarum sulphurescens) 4
MOUNTAIN SHOOTING STAR

(Dodecatheon conjugens)2

STICKY PURPLE GERANIUM

(Geranium viscosissimum)6

FIREWEED

(Epilobium angustifolium)5

GRASSES

ROUGH FESCUE

(Festuca scabrella) $\quad 19 \quad 18-20 \quad 100$

IDAHO FESCUE

(Festuca idahoensis) $\quad 4 \quad 1-6 \quad 100$

PARRY OATGRASS

(Danthonia parryi) $\quad 4 \quad 0-7 \quad 50$

HAIRY WILDRYE

(Elymus innovatus)

$15 \quad 14-15 \quad 100$

MOISTURE REGIME:

MESIC-SUBHYGRIC

NUTRIENT REGIME:

MESOTROPHIC-PERMESOTROPHIC

ELEVATION:

1643(1606-1680) M

SOIL DRAINAGE:

WELL

SLOPE:

$5(0-10) \%$

ASPECT:

EAST, LEVEL

Forage Production (KG/HA)

$\begin{array}{ll}\text { GrASS } & 1996(1580-2412) \\ \text { FORB } & 645(598-692) \\ \text { SHRUB } & 96(44-148) \\ \text { TOTAL } & 2737(222-3252)\end{array}$

SUGGESTED GRAZING CAPACITY

$0.3 \mathrm{HA} / \mathrm{AUM}$

ENVIRONMENTAL VARIABLES 


\section{B16. Big sagebrush-Buckthorn/Kentucky bluegrass (Artemisia tridentata-Rhamnus alnifolia/Poa pratensis)}

$\mathbf{n}=\mathbf{2} \quad$ This community type was described on the valley bottoms and meadows adjacent to the South Castle river. Buckthorn tends to grow in the moist areas of the meadows which have fine textured soils. In contrast big sagebrush is found on the drier, gravelly soils of old creek beds. These meadows have been extensively utilized by livestock and recreationists which has allowed Kentucky bluegrass, timothy and dandelion to become established in the understory of these shrub species. It is difficult to determine what the understory vegetation was prior to disturbance. It is felt that this site was probably dominated by rough fescue, but the presence of dark scaled sedge and graceful sedge appear to indicate a higher moisture regime than rough fescue-dominated communities. The establishment of an exclosure to protect the site from disturbance may help to answer this question.

\section{Plant Composition CANOPY COVER(\%) MEAN RANGE CONST.}

SHRUBS

BIG SAGEBRUSH

(Artemisia tridentata) $19 \quad 17-21 \quad 100$

SNOWBERRY

(Symphoricarpos occidentalis) $17 \quad 16-18 \quad 100$

BUCKTHORN

$\begin{array}{llll}\text { (Rhamnus alnifolia) } \quad 7 & 5-8 \quad 100\end{array}$

FORBS

STRAWBERRY

$\begin{array}{llll}\begin{array}{l}\text { (Fragaria virginiana) } \\ \text { YELLOW BEARDSTONGUE }\end{array} & 6 & 5-7 & 100 \\ \begin{array}{l}\text { (Penstemon confertus) } \\ \text { YARROW }\end{array} & 29 & 28-30 & 100 \\ \begin{array}{l}\text { (Achillea millefolium) } \\ \text { STAR FLW'D SOLOMON's SEAL }\end{array} & 8 & 7-9 & 100 \\ \begin{array}{l}\text { (Smilacina stellata) } \\ \begin{array}{l}\text { DANDELION } \\ \text { (Taraxacum officinale) }\end{array}\end{array} & 3 & 2-3 & 100 \\ \begin{array}{l}\text { HEART LV'D ALEXANDER } \\ \text { (Zizia aptera) }\end{array} & 1 & 0-1 & 50\end{array}$

\section{GRASSES}

KENTUCKY BLUEGRASS

\begin{tabular}{|c|c|c|}
\hline (Poa pratensis) & 25 & $14-36$ \\
\hline TIMOTHY & & \\
\hline (Phleum pratense) & 9 & 9 \\
\hline $\begin{array}{l}\text { DARK SCALED SEDGE } \\
\text { (Carex atrosquama) }\end{array}$ & 1 & $0-1$ \\
\hline (Carex praegracilis) & 1 & $0-1$ \\
\hline
\end{tabular}

\section{ENVIRONMENTAL VARIABLES}

MOISTURE REGIME:

MESIC-SUBHYGRIC

NUTRIENT REGIME:

MESOTROPHIC-PERMESOTROPHIC

ELEVATION:

$1440 \mathrm{M}$

SOIL DRAINAGE:

WELL TO MODERATELY WELL

SLOPE:

$1 \%$

ASPECT:

WEST

Forage Production (KG/HA)

$\begin{array}{ll}\text { GRASS } & 268 \\ \text { FORB } & 745 \\ \text { SHRUB } & 141 \\ \text { TOTAL } & 1154\end{array}$

SUGGESTED GRAZING CAPACITY

$0.8 \mathrm{HA} / \mathrm{AUM}$ 


\section{B17. Creeping spike rush \\ (Eleocharis palustris)}

$\mathrm{n}=1$ Thompson and Hansen (2002) described this type on somewhat alkaline sites in narrow bands along streams, rivers, lake margins and reservoirs. These sites are subject to yearly flooding. Typically these sites are almost pure stands of creeping spike rush. Creeping spike rush is generally unpalatable to livestock and the wet conditions limit livestock use. This community type should be rated as non-use.

\section{PLANT COMPOSITION CANOPY COVER(\%)}

MEAN

RANGE CONST.

\section{GRASSES}

CREEPING SPIKE RUSH

(Eleocharis palustris)

$98 \quad-\quad 100$

\section{Forage Production (KG/HA)}

TOTAL $1200 *$ ESTIMATE

\section{ENVIRONMENTAL VARIABLES}

\author{
MOISTURE REGIME: \\ HYDRIC \\ NUTRIENT REGIME: \\ PERMESOTROPHIC \\ ELEVATION: \\ $1375 \mathrm{M}$
}

SOIL DRAINAGE:

IMPERFECTLY

SUGGESTED GRAZING CAPACITY NON-USE 


\section{B18. Small fruited bulrush \\ (Scripus microcarpus)}

$\mathbf{n}=1 \quad$ This community type is associated with wet areas along the edges of perennial streams, marshes and ponds. It has similar site conditions to the beaked and water sedge dominated meadows, where drainage is better than the Great bulrush and cattail dominated community types. The wet conditions and generally poor palatability of small fruited bulrush limits it use. This community should be rated as non-use.

\section{PlaAt COMPOSITION CANOPY COVER(\%) MEAN RANGe CONST.}

\section{FORBS}

CURLED DOCK

(Rumex crispus)

3

GRASSES

TUFTED HAIRGRASS

(Deschampsia cespitosa) 3

BEAKED SEDGE

(Carex rostrata) 3

SMALL FRUITED BULRUSH

(Scirpus microcarpos) 98
$-$

RANGE CONST.

$\begin{array}{ll}- & 100 \\ - & 100 \\ - & 100 \\ - & 100\end{array}$

100

100

100

100

\section{ENVIRONMENTAL VARIABLES}

MOISTURE REGIME:

SUBHYDRIC

NUTRIENT REGIME:

PERMESOTROPHIC

ELEVATION:

$1410 \mathrm{M}$

SOIL DRAINAGE:

IMPERFECTLY

FORAGE PRODUCTION (KG/HA)

TOTAL $1500 *$ ESTIMATE

SugGested GRAZING CAPACITY NON-USE 


\section{B19. Great bulrush \\ (Scirpus acutus)}

$\mathbf{n}=\mathbf{2}$ This community type occurs along the margins of ponds and lakes (Thompson and Hansen 2002). Great bulrush tends to be found growing in the water. Often the water is up to $2 \mathrm{~m}$ deep. This community type is much wetter than the previously described small fruited bulrush community. The wet conditions and unpalatability of great bulrush limits the use of this community type. This community should be rated as non-use.

Plant COMPOSITION CANOPY COVER(\%)

MEAN RANGE CONST.

\section{FORBS}

WATER SMARTWEED

(Equisetum fluviatile)

40

$0-80$

50

\section{GRASSES}

BEAKED SEDGE

(Carex rostrata)

GREAT BULRUSH

(Scirpus acutus)

\begin{abstract}
RANGE CONST.
\end{abstract}

\section{ENVIRONMENTAL VARIABLES}

MOISTURE REGIME:

HYDRIC

NUTRIENT REGIME:

PERMESOTROPHIC

ELEVATION:

1291(1219-1363)M

SOIL DRAINAGE:

VERY POORLY

FORAGE PRODUCTION (KG/HA)

Total 2200*ESTIMATE

\section{SUGGESTED GRAZING CAPACITY}

NON-USE 


\section{B20. Cattail \\ (Typha latifolia)}

$\mathbf{n}=\mathbf{2}$ This community type is associated with standing water. Thompson and Hansen (2002) have found that the saturated or inundated conditions tend to limit species diversity. The wet conditions limit us by domestic livestock and this community type should be rated as non-use.

\section{PLANT COMPOSITION CANOPY COVER(\%)}

\section{MEAN RANGE CONST.}

\section{FORBS}

SWAMP HORSETAIL

$\begin{array}{llll}\begin{array}{l}\text { (Equisetum fluviatile) } \\ \text { CATTAIL }\end{array} & 2 & 0-3 & 50 \\ \begin{array}{l}\text { (Typha latifolia) } \\ \text { Typ }\end{array} & 94 & 90-97 & 100\end{array}$

GRASSES

BEAKED SEDGE

(Carex rostrata)

GREAT BULRUSH

(Scirpus acutus)

$5 \quad 0-10 \quad 50$

$1 \quad 0-1 \quad 50$

\section{ENVIRONMENTAL VARIABLES}

MOISTURE REGIME:

HYDRIC

NUTRIENT REGIME:

PERMESOTROH HIC

ELEVATION:

1291(1219-1363) M

SOIL DRAINAGE:

VERY POORLY

\section{FORAGE PRODUCTION (KG/HA)}

TOTAL 2500*ESTIMATE

Suggested GRAZING CAPACITY

NON-USE 
MONTANE SUBREGION

BLAIRMORE AND MORLEY FOOTHILLS ECODISTRICTS

DISTURBED GRASSLAND COMMUNITY TYPES

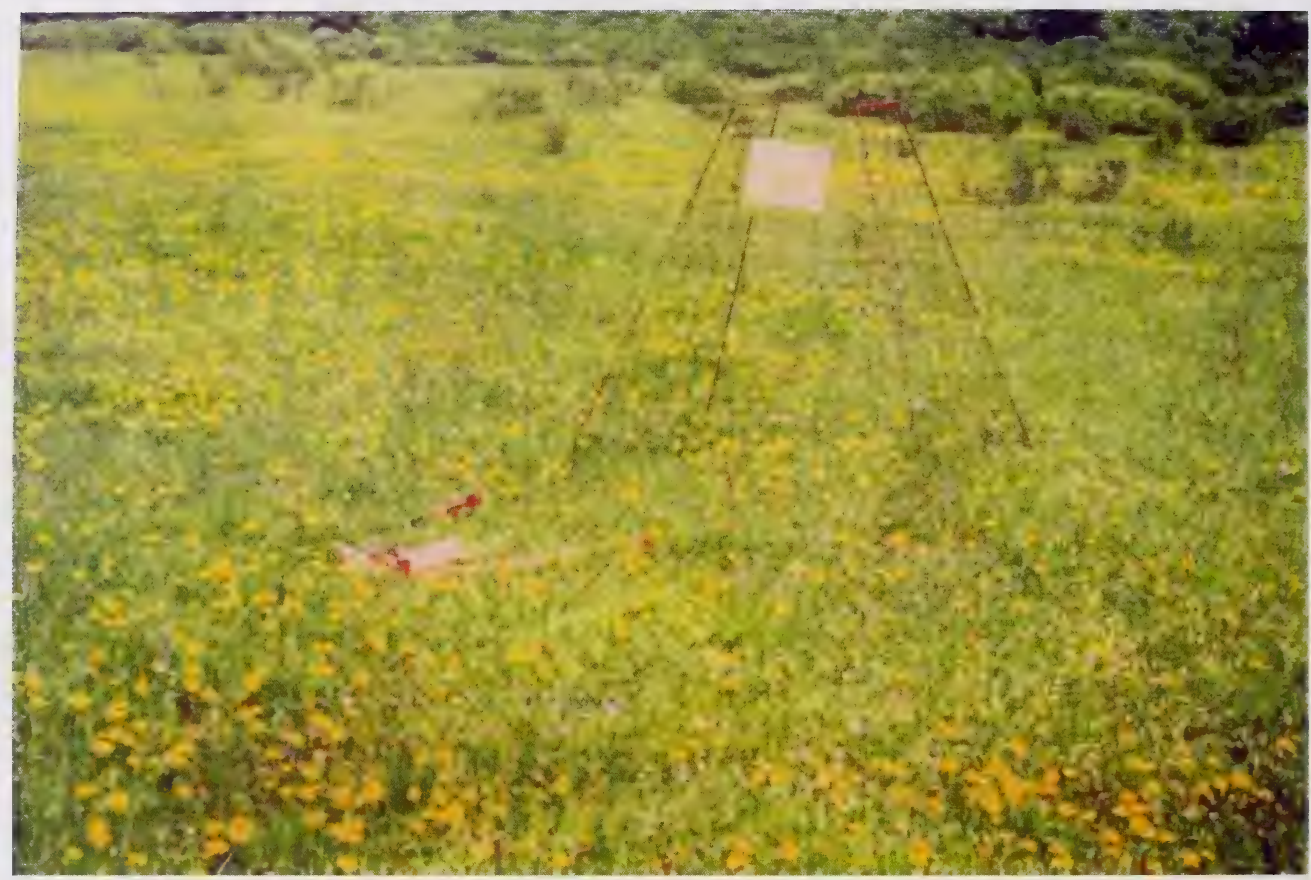

Photo 6: The dominance of Kentucky bluegrass, dandelion and clover indicate that this is an overgrazed grassland. Once Kentucky bluegrass has established dominance, the site will not return to the original vegetation composition when protected from grazing. Instead it will move to another community type, dominated by Kentucky bluegrass and native species such as rough fescue. 


\section{C1. Idaho fescue-Parry oatgrass-Sedge (Festuca idahoensis-Danthonia parryi-Carex obtusata)}

$\mathbf{n}=\mathbf{3 2}$ This community type represents a Rough fescue-Idaho fescue-Parry oatgrass plant community that has been moderately to heavily grazed for a number of years. The species composition of this community is very similar to the Idaho fescue-Parry oatgrass-Rough fescue community types, but this community type occupies lower slope positions, whereas the latter community occupies mid to upper slope positions.

Increased grazing pressure causes rough fescue to decline and allows Idaho fescue, Parry oatgrass and sedge species to increase. Continued heavy grazing pressure will eventually lead to a decline in all native species and Kentucky bluegrass and dandelion will dominate the site. If grazing pressure on this community type is reduced or is eliminated the type will likely succeed back to a rough fescue dominated grassland. However, if the present grazing pressure continues Kentucky bluegrass will likely dominate the site. Recovery of this grassland back to a rough fescue dominated community type will likely take 20-30 years (Willoughby 1996).

Plant COMPOSITION CANOPY Cover(\%) MEAN RANGE CONST.

SHRUBS

SHRUBBY CINQUEFOIL

(Potentilla fruticosa)

$1 \quad 0-12 \quad 41$

FORBS

THREE FLOWERED AVENS

(Geum triflorum)

COMMON YARROW

(Achillea millefolium)

DANDELION

(Taraxacum officinale)

GRACEFUL CINQUEFOIL

(Potentilla gracilis)

NORTHERN BEDSTRAW

(Galium boreale)

GraSSES

ROUGH FESCUE

(Festuca scabrella)

IDAHO FESCUE

(Festuca idahoensis)

PARRY OATGRASS

(Danthonia parryi)

BLUNT SEDGE

(Carex obtusata)

KENTUCKY BLUEGRASS

(Poa pratensis)

3

5

$3 \quad 0-9 \quad 93$

$1 \quad 0-13 \quad 59$

$3 \quad 0-9 \quad 84$

$\begin{array}{lll}5 & 0-14 \quad 88\end{array}$

$16 \quad 1-77 \quad 100$

$10 \quad 0-63 \quad 67$

$2 \quad 0-49 \quad 47$

$\begin{array}{lll}6 & 0-24 & 75\end{array}$
$5 \quad 0-19 \quad 53$

$1 \quad 0-9 \quad 63$

ENVIRONMENTAL VARIABLE

MOISTURE REGIME:

SUBMESIC-MESIC

NUTRIENT REGIME

MESOTROPHIC TO PERMESOTROPHIC

ElEVATION:

$1489(1330-1920) \mathrm{M}$

SOIL DRAINAGE:

RAPIDLY TO WELL

SLOPE:

$13(2-36) \%$

ASPECT:

SOUTH AND WEST

Forage Production (KG/HA)

GRASS $1157(582-2796)$

FORB 508(0-1230)

SHRUB 10(0-78)

TOTAL $1674(836-3134)$

SUGGESTED GRAZING CAPACITY $0.5 \mathrm{HA}$ AUM 


\section{C2. Canada bluegrass-Rough fescue-Slender wheatgrass \\ (Poa compressa-Festuca scabrella-Agropyron trachycaulum)}

n=14 This community type was described on mesic, lower slope positions with shallow, nutrient poor soils. The presence of blunt sedge, junegrass and plains reedgrass are all indicative of dry, nutrient poor sites. The dominance of Canada bluegrass an introduced, occasional species that is adapted to grow on waste ground also appears to indicate that this community type is typical of nutrient poor soils. This community type appears to have also been moderately grazed. increased grazing pressure causes rough fescue to decline and allows Canada bluegrass and dandelion to increase.

\section{Plant COMPOSITION CANopy Cover(\%)} Mean Range Const.

SHRUBS

SHRUBBY CINQUEFOIL

(Potentilla fruticosa)

$3 \quad 0-20 \quad 57$

\section{FORBS}

OLD MAN'S WHISKERS

(Geum triflorum)

COMMON YARROW

(Achillea millefolium)

DANDELION

(Taraxacum officinale)

GRACEFUL CINQUEFOIL

(Potentilla gracilis)

NORTHERN BEDSTRAW

(Galium boreale)

Grasses

ROUGH FESCUE

(Festuca scabrella)

IDAHO FESCUE

(Festuca idahoensis)

PARRY OATGRASS

(Danthonia parryi)

BLUNT SEDGE

(Carex obtusata) 6

CANADA BLUEGRASS

(Poa compressa)

$\begin{array}{lll}3 & 0-7 & 79\end{array}$

$\begin{array}{lll}7 & 1-15 \quad 100\end{array}$

$8 \quad 0-24 \quad 86$

$3 \quad 0-13 \quad 79$

$4 \quad 0-12 \quad 92$

$\begin{array}{lll}7 & 0-26 & 79\end{array}$

$8 \quad 0-44 \quad 71$

$3 \quad 0-13 \quad 36$

$0-19 \quad 62$

$20 \quad 0-51 \quad 79$

\section{ENVIRONMENTAL VARIABLES}

MOISTURE REGIME:

SUBMESIC-SUBHYGRIC

NUTRIENT REGIME

MESOTROPHIC

ELEVATION:

1476(1320-1631) M

SOIL DRAINAGE:

RAPIDLY TO WELL

SLOPE:

$$
14(0-30) \%
$$

ASPECT:

SOUTHERLY

\section{FORAGE PRODUCTION (KG/HA)}

GRASS 1455(5-3042)

FORB 542(0-878)

SHRUB 9(0-44)

TOTAL 1637(5-3692)

SUGGESTED GRAZING CAPACITY 0.5 HAAUM 


\section{C3. Kentucky bluegrass-Rough fescue \\ (Poa pratensis-Festuca scabrella)}

$\mathbf{n}=\mathbf{7 0}$ Long-term heavy grazing pressure leads to decline in rough fescue and an increase in Parry oatgrass and sedge species. Continued grazing pressure reduces the competitive advantage of rough fescue and the other native grass species and allows Kentucky bluegrass to establish on the site. Continued heavy grazing pressure eventually leads to a decline in all native species and the plant community will resemble a Timothy-Kentucky bluegrass/ Dandelion type.

The shallow, nutrient poor soils of the Canada bluegrass dominated community type do not appear to favour the growth of Kentucky bluegrass under similar grazing conditions and may explain the lack of Kentucky bluegrass in the Canada bluegrass-Rough fescue-Slender wheatgrass community type.

The forage productivity of this community type $(2600 \mathrm{~kg} / \mathrm{ha})$ is equivalent to or better than a lightly grazed Rough fescue-Parry oatgrass community $(2015 \mathrm{~kg} / \mathrm{ha})$. However, rough fescue is a much more desirable forage species because it maintains its nutrient content into the dormant season. In contrast, Kentucky bluegrass loses its palatability, and nutrient content if it is allowed to flower and set seed.

Plant Composition Canopy Cover(\%) Mean Range Const.

SHRUBS

SHRUBBY CINQUEFOIL

(Potentilla fruticosa)

2

$0-11$

50

FORBS

YARROW

(Achillea millefolium)

OLD MAN'S WHISKERS

(Geum triflorum)

DANDELION

(Taraxacum officinale)

GRACEFUL CINQUEFOIL

(Potentilla gracilis)

GRASSES

PARRY OATGRASS

(Danthonia parryi)

ROUGH FESCUE

(Festuca scabrella) $\quad 7 \quad 0-30 \quad 77$

IDAHO FESCUE

(Festuca idahoensis) $\quad 6 \quad 0-39 \quad 78$

BLUNT SEDGE

(Carex obtusata)

KENTUCKY BLUEGRASS

(Poa pratensis)

ТімотнY

(Phleum pratense)
$5 \quad 0-41 \quad 61$

$5 \quad 0-42 \quad 81$

$2 \quad 0-13 \quad 63$

$3 \quad 0-21 \quad 60$

$3 \quad 0-18 \quad 44$

$27 \quad 0-80 \quad 96$

$6 \quad 0-31 \quad 63$
$5 \quad 0-41 \quad 93$
ENVIRONMENTAL VARIABLES

MOISTURE REGIME:

SUBMESIC TO MESIC

NUTRIENT REGIME:

MESOTROPHIC TO PERMESOTROPHIC

ELEVATION:

$1487(1300-1768) \mathrm{M}$

SOIL DRAINAGE:

WELL TO MODERATELY WELL

SLOPE:

$16(5-55) \%$

ASPECT:

SOUTHERLY

FORAGE PRODUCTION (KG/HA)

GRASS $1749(118-5028)$

FORB $587(0-1720)$

SHRUB $47(0-270)$

TOTAL 2365(566-5886)

\section{SUGGESTED GRAZING CAPACITY} $0.4 \mathrm{HA} / \mathrm{AUM}$ 


\section{C4. Kentucky bluegrass-Timothy/Dandelion (Poa pratensis-Phleum pratense/Taraxacum officinale)}

$\mathbf{n = 7 2}$ This community type appears to once have represented a Rough fescue-Parry oatgrass-Idaho fescue community type on Black Chernozmic soils. Conitunued heavy grazing at the beginning of the century has shifted the community to one dominated by Kentucky bluegrass, timothy and dandelion.

The climax range condition model suggests that vegetation development will be directional, predictable and revert to the original vegetation when protected from grazing, but once Kentucky bluegrass has established, bluegrass appears to compete with rough fescue for codominance. When protected from grazing these Kentucky bluegrass dominated types move toward a different community type rather than back to the original vegetation. These sites closely follow the "State transition model" proposed by Westoby et al. (1989).

\section{Plant Composition Canopy Cover(\%) Mean Range CONST.}

SHRUBS

SNOWBERRY

(Symphoricarpos occidentalis) $1 \quad 0-18 \quad 10$

\section{FORBS}

GRACEFUL CINQUEFOIL

(Potentilla gracilis) 4

DANDELION

(Taraxacum officinale) $12 \quad 0-51 \quad 92$

COMMON YARROW

(Achillea millefolium) 6

MOUSE EARED CHICKWEED

(Cerastium arvense) 1

STICKY PURPLE GERANIUM

(Geranium viscosissimum)2

\section{GRASSES}

KENTUCKY BLUEGRASS

$\begin{array}{llll}\text { (Poa pratensis) } & 34 & 0-92 & 97\end{array}$

Тімотну

(Phleum pratense) $\quad 24 \quad 0-90 \quad 92$

ROUGH FESCUE

(Festuca scabrella) $\quad 1 \quad 0-12 \quad 26$

IDAHO FESCUE

(Festuca idahoensis) $\quad 1 \quad 0-23 \quad 25$

SLENDER WHEATGRASS

(Agropyron trachycaulum) $1 \quad 0-17 \quad 44$

\section{ENVIRONMENTAL VARIABLES}

MOISTURE REGIME:

MESIC-SUBMESIC

NUTRIENT REGIME:

PERMESOTROPHIC-MESOTROPHIC

ELEVATION:

1485(1350-1682) M

SOIL DRAINAGE:

WELL TO MODERATELY WELL

SLOPE:

$$
5(0-36) \%
$$

ASPECT:

SOUTH TO WESTERLY

\section{Forage Production (KG/HA)}

GRASS $1762(244-3308)$

FORB 696(0-4790)

SHRUB 52(0-640)

TOTAL 2510(284-5242)

\section{SUGGESTED GRAZING CAPACITY}

0.4 HA/AUM 


\section{C5. Smooth brome-Kentucky bluegrass \\ (Bromus inermis-Poa pratensis)}

$\mathrm{n}=14$ These sites probably were once rough fescue dominated. Cultivation and extreme grazing pressure have led to a decline in all native species. If these sites had been left undisturbed they would probably resemble a Rough fescue-Parry oatgrass-Idaho fescue community type.

Plant COMPOSITION CANOPY COVER(\%) Mean Range Const.

FORBS

CANADA THISTLE

(Cirsium arvense)

COMMON YARROW

$\begin{array}{llll}\begin{array}{l}\text { (Achillea millefolium) } \\ \text { STRAWBERRY }\end{array} & 2 & 0-5 & 79 \\ \begin{array}{l}\text { (Fragaria virginiana) } \\ \text { (Frian }\end{array} & 3 & 0-23 & 36\end{array}$

\section{GRASSES}

KENTUCKY BLUEGRASS

(Poa pratensis)

SMOOTH BROME

(Bromus inermis)

SLENDER WHEATGRASS

(Agropyron trachycaulum) $1 \quad 0-9 \quad 50$

TIMOTHY

(Phleum pratense) $\begin{array}{lll}36 & 0-87 \quad 86\end{array}$

$40 \quad 2-78 \quad 100$

$0-23 \quad 71$

\section{ENVIRONMENTAL VARIABLES}

MOISTURE REGIME:

MESIC

NUTRIENT REGIME:

SUBMESOTROPHIC-PERMESOTROPHIC

ELEVATION:

1445(1300-1768) M

SOIL DRAINAGE :

WELL

SLOPE:

$8(0-60) \%$

ASPECT:

SOUTH TO WEST

Forage Production (KG/HA)

GRASS 1761(900-3204)

FORB 260(44-528)

SHRUB 26(0-150)

TOTAL 1822(1300-3204)

Suggested GRAZING CAPACITY

0.5 HA/AUM 


\section{C6. Sedge/Little clubmoss-Moss phlox \\ (Carex obtusata/Selaginella densa-Phlox hoodii)}

n=5 On dry, gravelly sites within the Parry oatgrass-Rough fescue and Bluebunch wheatgrass dominated community types increased grazing pressure causes Parry oatgrass, rough fescue and bluebunch wheatgrass to decline and allows low growing sedge and forb species to increase to form this community type. Indeed one of the sites (Stoddo) represents the outside transect of a rangeland reference area (Willoughby 1992). The inside transect which has been protected from grazing pressure belongs to the Idaho fescue-Parry oatgrass-Rough fescue community type.

\section{Plant COMPOSITION CANOPY COVER(\%)} Mean Range Const.

SHRUBS

SHRUBBY CINQUEFOIL

$\begin{array}{llll}\text { (Potentilla fruticosa) } & 1 & 0-3 \quad 80\end{array}$

\section{FORBS}

LITTLE CLUBMOSS

(Selaginella densa) 24

SMALL LEAVED EVERLASTING

(Antennaria parviflora) 3

NODDING ONION

(Allium cernuum)

MOSS PHLOX

(Phlox hoodii)

FRINGED SAGE

(Artemisia frigida)

1

1

13

$5-20$

$3 \quad 1-4 \quad 100$

Grasses

BLUNT SEDGE

(Carex obtusata)

JUNEGRASS

(Koeleria macrantha)

ROUGH FESCUE

(Festuca scabrella)

PARRY OATGRASS

(Danthonia parryi)

NORTHERN WHEATGRASS

(Agropyron dasystachyum) 4

\section{$0-42 \quad 80$}

$0-12 \quad 60$

$0-1 \quad 40$

00
$11 \quad 0-17 \quad 80$

$0-14 \quad 40$

\section{ENVIRONMENTAL VARIABLES}

MOISTURE REGIME:

SUBMESIC

NUTRIENT REGIME:

SUBMESOTROPHIC TO MESIC

ELEVATION(RANGE):

1631 (1424-1787) M

SOIL DRAINAGE:

RAPIDLY TO WELL

SLOPE (RANGE):

$12(0-26) \%$

ASPECT:

SOUTHWEST

Forage Production (KG/HA)

GRASS 460(194-732)

FORB 355(182-742)

SHRUB $67(0-167)$

TOTAL 881(476-1474)

SUGGESTED GRAZING CAPACITY $1.0 \mathrm{HA} / \mathrm{AUM}$ 


\section{C7. Creeping red fescue/Dandelion-Clover (Festuca rubra/Taraxacum offincinale-Trifolium repens)}

$\mathbf{n = 1 0}$ This community is an example of a rough fescue grassland which has been modified during reclamation of a natural gas pipeline and power transmission lines. Seed from the reclamation has influenced the plant association such that creeping red fescue and Kentucky bluegrass now dominate the site. Previously tame species like creeping red fescue were used in reclamation with little thought given to compatibility with surrounding native vegetation. It is now recognized that native species that promote the recovery of the original community structure and function should be used in reclamation (Gerling et al. 1996).

\section{Plant COMPOSITION CANopy Cover(\%) Mean Range CONST.}

\section{FORBS}

DANDELION

(Taraxacum officinale)

WHITE DUTCH CLOVER

(Trifolium repens)

SWEET CLOVER

(Melilotus alba)

ALFALFA

(Medicago sativa)

COMMON YARROW

(Achillea millefolium)

STRAWBERRY

(Fragaria virginiana)

$0-18$

90

$9 \quad 0-49 \quad 50$

$1 \quad 0-11 \quad 10$

$3 \quad 0-26 \quad 10$

$1 \quad 0-5 \quad 70$

$30 \quad 15 \quad 70$
GraSSES

TIMOTHY

(Phleum pratense)

CREEPING RED FESCUE

(Festuca rubra)

BLUNT SEDGE

(Carex obtusata) 1

KENTUCKY BLUE GRASS

(Poa pratensis)

$\begin{array}{lll}7 & 1-19 & 100\end{array}$

$52 \quad 22-83 \quad 100$

$0-7 \quad 10$

$\begin{array}{lll}8 & 0-27 \quad 90\end{array}$

\section{ENVIRONMENTAL VARIABLES}

MOISTURE REGIME:

SUBMESIC TO SUBHYGRIC

NUTRIENT REGIME:

MESOTROPHIC TO PERMESOTROPHIC

ELEVATION(RANGE):

1503(1380-1615)M

SOIL DRAINAGE:

RAPIDLY TO MODERATELY WELL

SLOPE (RANGE):

$$
8(4-10) \%
$$

ASPECT:

SOUTH

Forage ProduCtion (KG/HA)

GRASS 1833(968-2600)

FORB 601(54-1044)

TOTAL 2434(2012-2654)

SUGGESTED GRAZING CAPACITY $0.4 \mathrm{HA} / \mathrm{AUM}$ 


\section{C8. Northern wheatgrass-Kentucky bluegrass \\ (Agropyron dasystachyum-Poa pratensis)}

$\mathbf{n}=1$ This community type is found on a dry, moderately to heavily grazed, south-facing slopes with shallow soils above the Oldman river in the Outer Gap range allotment. The moisture regime is not high enough to allow complete invasion of Kentucky bluegrass and dandelion. In the absence of disturbance the community type would probably resemble moister sites within the Bluebunch wheatgrass-Sedge community type.

The Outer Gap allotment is subject to extremely high, dessicating winds. As a result, the climate is very similar to the grasslands described in Rocky Foothills and Rocky Mountain ecodistricts. Indeed many of the species characteristic of the grasslands described in these ecodistricts (junegrass, northern wheatgrass, blunt sedge, small leaved everlasting) are found in this community type.

\section{Plant COMPOSITION CANOPY COVER(\%) Mean Range Const.}

SHRUBS

SNOWBERRY

(Symphoricarpos occidentalis) 12 - 100

PRAIRIE ROSE

(Rosa arkansana) $\quad 7 \quad-\quad 100$

FORBS

DANDELION

(Taraxacum officinale) $14 \quad-\quad 100$

AMERICAN VETCH

(Vicia americana)

$13 \quad-\quad 100$

SMALL LEAVED EVERLASTING

(Antennaria parviflora) 10

SHOWY LOCOWEED

$\begin{array}{llll}\text { (Oxytropis splendens) } & 8 & - & 100\end{array}$

LOW GOLDENROD

(Solidago missouriensis) 6

\section{GRASSES}

NORTHERN WHEATGRASS

(Agropyron dasystachyum)35 - 100

KENTUCKY BLUEGRASS

(Poa pratensis)

BLUNT SEDGE

(Carex obtusata)

CANBY BLUEGRASS

(Poa canbyi)

$\begin{array}{lll}16 & - & 100 \\ 10 & - & 100 \\ 5 & - & 100\end{array}$

\section{ENVIRONMENTAL VARIABLES}

MOISTURE REGIME:

SUBMESIC

NUTRIENT REGIME:

MESOTROPHIC

ELEVATION:

$1545 \mathrm{M}$

SOIL DRAINAGE:

WELL

SLOPE:

$15 \%$

ASPECT:

SOUTHERLY

Forage Production Kg/HA

GRASS $\quad 1112$

FORB $\quad 642$

SHRUB 82

TOTAL 1836

SUGgESTED GRAZING CAPACITY

$0.5 \mathrm{HA} / \mathrm{AUM}$ 


\section{C9. Rough fescue-Kentucky bluegrass \\ (Festuca scabrella-Poa pratensis)}

$\mathbf{n}=\mathbf{2 8}$ This community type represents grasslands that have been grazed heavily to the point of Kentucky bluegrass invasion and are now recovering, or ungrazed exclosures that have been invaded by Kentucky bluegrass. Long-term heavy grazing pressure leads to a decline in rough fescue and an increase in Parry oatgrass and sedge species. Continued grazing pressure reduces the competitive advantage of rough fescue and the other native grass species and allows Kentucky bluegrass to establish on the site. Prntection or a reduction in stocking level at the point where Kentucky bluegrass has become a significant component of the community allows rough fescue to recover, but it seems Kentucky bluegrass also remains as codominant. Willoughby (1996), found that some rangeland reference area sites which were protected from grazing before Kentucky bluegrass became established recovered to Rough fescue-Idaho fescue-Parry oatgrass in 20-30 years. In contrast sites that had significant Kentucky bluegrass invasion recovered to Rough fescue-Kentucky bluegrass dominated sites over the same time period. It appears that both the unidirectional climax range condition model proposed by Dysterhuis (Wroe et al. 1988) and the State and Threshold model proposed by Westoby et al. (1989) apply to the successional sequences of the rough fescue grasslands of southwestern Alberta. This makes it extremely difficult to assess range health on these sites (Willoughby and Alexander 2000). That is why the Ecological site and Desired Plant community concepts proposed by the Task Group on Unity in Concepts and Terminology (1995) have been adopted to determine range health on these rangelands.

Plant COMPOSITION CANOPY COVER(\%) Mean Range Const.

SHRUBS

SHRUBBY CINQUEFOIL

(Potentilla fruticosa)

$3 \quad 0-33$

61

\section{FORBS}

YARROW

(Achillea millefolium)

OLD MAN'S WHISKERS

(Geum triflorum)

DANDELION

(Taraxacum officinale)

GRACEFUL CINQUEFOIL

(Potentilla gracilis)

AMERICAN VETCH

(Vicia american)

GRASSES

PARRY OATGRASS

(Danthonia parryi)

ROUGH FESCUE

(Festuca scabrella)

KENTUCKY BLUEGRASS

(Poa pratensis)

TIMOTHY

(Phleum pratense)

$\begin{array}{ccc}4 & 0-16 & 89 \\ 8 & 0-30 & 75 \\ 1 & 0-5 & 61 \\ 1 & 0-6 & 50 \\ 1 & 0-6 & 57\end{array}$

$4 \quad 0-15 \quad 82$

$22 \quad 9-44 \quad 100$

$11 \quad 0-41 \quad 89$

$3 \quad 0-20 \quad 43$

\section{ENVIRONMENTAL VARIABLES}

\section{MOISTURE REGIME:}

MESIC TO SUBHYGRIC

NUTRIENT REGIME: MESOTROPHIC TO PERMESOTROPHIC

ELEVATION(RANGE): $1507(1330-1660) \mathrm{M}$

SOIL DRAINAGE:

WELL TO MODERATELY WELL

SLOPE (RANGE): $10(0-32) \%$

ASPECT:

SOUTHERLY

\section{Forage Production (KG/HA)}

GRASS 1135(398-2246)

FORB 449(20-1116)

SHRUB 28(0-150)

TOTAL 1611(456-2742)

\section{SUGGESTED GRAZING CAPACITY}

$0.5 \mathrm{HA} / \mathrm{AUM}$ 


\section{C10. Rough fescue-Sedge- Mountain brome (Festuca scabrella-Carex obtusata-Bromus carinatus)}

$\mathbf{n}=\mathbf{2}$ This community type represents grasslands that have been grazed moderately. Bromus carinatus is an introduced species that is well adapated to moist woods and dry open meadows. The two sites where this community were described were on lower slope positions.

\section{Plant COMPOSITION CANOPY COVER(\%) \\ MEAN RANGE CONST.}

FORBS

YARROW

(Achillea millefolium)

OLD MAN'S WHISKERS

(Geum triflorum)

DANDELION

(Taraxacum officinale)

YELLOW BEARDSTONGUE

(Penstemon confertus)

ALPINE BISTORT

(Polygonum viviparum)

AMERICAN VETCH

(Vicia americana)

GRASSES

PARRY OATGRASS

(Danthonia parryi)

ROUGH FESCUE

(Festuca scabrella)

MOUNTAIN BROME

(Bromus carinatus)

IDAHO FESCUE

(Festuca idahoensis)

$\begin{array}{lll}1 & 1 & 100 \\ 3 & 1-5 & 100 \\ 1 & 0-1 & 50 \\ 5 & 0-10 & 50 \\ 4 & 0-7 & 50 \\ 3 & 0-6 & 50\end{array}$

$1 \quad 0-1 \quad 50$

$18 \quad 14-21 \quad 100$

$23 \quad 3-43 \quad 100$

$5 \quad 3-5 \quad 100$

\section{ENVIRONMENTAL VARIABLES}

MOISTURE REGIME :

MESIC TO SUBMESIC

NUTRIENT REGIME:

PERMESOTROPHIC

ELEVATION(RANGE):

$1540(1494-1585) \mathrm{M}$

SOIL DRAINAGE:

WELL TO RAPIDLY

SLOPE:

$45 \%$

ASPECT:

SOUTHEASTERLY

Forage ProdCUCTION (KG/HA)

$\begin{array}{ll}\text { GRASS } & 2185(1170-3200) \\ \text { FORB } & 136(60-212) \\ \text { TOTAL } & 2321(1230-3412)\end{array}$

SugGeSted GRAZING CAPACITY

$0.4 \mathrm{HA} / \mathrm{AUM}$ 


\section{C11. Snowberry/Kentucky bluegrass \\ (Symphoricarpus occidentalis/Poa pratensis)}

$\mathbf{n}=3$ This community type was described on lower slope positions along the valley bottoms of the Porcupine Hills. The increased moisture content on these sites favours the growth of snowberry which has slowly invaded into the surrounding grasslands. Snowberry is common in the understory of many aspen communities throughout the Montane subregion. It is likely this community type will eventually become dominated by aspen.

The high moisture and nutrient content of the site make this a very productive community type, but the high snowberry cover limits its use by livestock. Snowberry is very resistant to fire and sprouts readily after burning. It has been found that mowing followed by herbicide treatment is effective in controlling snowberry growth.

\section{Plant CoMposition CANOPY COVER(\%) MEAN RANGE CONST.}

\section{SHRUBS}

SNOWBERRY

(Symphoricarpos

occidentalis,albus)

$54 \quad 51-70 \quad 100$

\section{FORBS}

DANDELION

$\begin{array}{lccc}\begin{array}{l}\text { (Taraxacum officinale) } \\ \text { YARROW }\end{array} & 2 & 0-3 & 67 \\ \begin{array}{l}\text { (Achillea millefolium) } \\ \text { AMERICAN VETCH } \\ \text { (Vicia americana) }\end{array} & 1 & 1-3 & 100 \\ & 1 & 1-2 & 100\end{array}$

GraSSES

KENTUCKY BLUEGRASS

(Poa pratensis)

QUACKGRASS

(Agropyron repens)

TIMOTHY

(Phleum pratense)

\section{ENVIRONMENTAL VARIABLES}

MoISTURE REGIME :

MESIC TO SUBHYGIC

NUTRIENT REGIME:

MESOTROPHIC TO PERMESOTROPHIC

ELEVATION:

1365(1350-1372)M

SOIL DRAINAGE:

WELL

SLOPE:

$10 \%$

ASPECT:

SOUTHERLY

Forage Production (KG/HA)

GRASS 1184

FORB 0

SHRUB 2464

TOTAL 3648

\section{SUGGESTED GRAZING CAPACITY $0.8 \mathrm{HA} / \mathrm{AUM}$}

(BASED ONLY ON GRASS PRODUCTION) 


\section{C12. Aspen/Orchardgrass-Kentucky bluegrass \\ (Populus tremuloided/Dactylis glomerata-Poa pratensis)}

$\mathbf{n}=\mathbf{2}$ This community dominated by a regenerating aspen overstory and an understory of orchardgrass and Kentucky bluegrass represents old range improvement areas in the East Trout allotment in the Porcupine Hills. A number of treatments such as dragging and herbicide have been used to control aspen regeneration on these sites in the Porcupine Hills. These range improvement techniques should be considered for controlling aspen regeneration on this community type.

\section{Plant COMPOSITION CANOPY COVER(\%)} Mean RANGe Const.

\section{TREES}

ASPEN

(Populus tremuloides) $14 \quad 0-28 \quad 50$

SHRUBS

SASKATOON

(Amelanchier alnifolia) $\quad 1 \quad 0-2 \quad 50$

ROSE

(Rosa acicularis)

$4 \quad 0-7 \quad 50$

FORBS

LINDLEY'S ASTER

(Aster ciliolatus)

STRAWBERRY

$\begin{array}{llll}\text { (Fragaria virginiana) } & 5 & 1-9 & 100\end{array}$

AMERICAN VETCH

(Vicia americana)

\section{Grasses}

KENTUCKY BLUEGRASS

(Poa pratensis)

ORCHARDGRASS

(Dactylis glomerata)

$\begin{array}{lll}11 & 1-21 & 100 \\ 5 & 1-9 & 100 \\ 1 & 1-2 & 100\end{array}$

$12 \quad 9-14 \quad 100$

$25 \quad 11-37 \quad 100$

\section{ENVIRONMENTAL VARIABLES}

MOISTURE REGIME :

MESIC

NUTRIENT REGIME:

MESOTROPHIC

ELEVATION:

1525(1495-1555)M

SOIL DRAINAGE:

WELL

SLOPE:

$12(10-15 \%)$

ASPECT:

SOUTHERLY

Forage Production (KG/HA)

GRASS 803

FORB $\quad 466$

SHRUB 53

TOTAL 1322

\section{SUGGESTED GRAZING CAPACITY \\ 0.7 HA AUM}




\section{MONTANE SHRUBLAND ECOLOGY}

Shrubland communities in the montane subregion of Alberta occur in valley bottoms, depressional areas, and on moist upland seepage areas. They are highly diverse and dynamic communities that represent transition from wetland to forest or seral stages of development following disturbance. The Green alder-Scouler's willow-Wild red raspberry, Bebb willow/Hairy wild rye and Hawthorn-Snowberry $/ \mathrm{K}$. bluegrass community types are found on moist, upland sites. They represent seral stages of development following disturbance. The Green alder-Scouler's willow-Wild red raspberry community type is found on moderate northerly slopes and the Beaked willow/Hairy wild rye community type is found on south-facing slopes with high moisture and nutrient regimes. The Hawthorn-Snowberry dominated community is often associated with small drainages and seepage areas. These upland shrublands provide excellent forage for wildlife in the early stages of succession.

Lowland shrublands are found in low, marshy or bog sites and are often considered the edaphic climax communities on these sites since the wet cool soil conditions often prevent succession to forest. However, where organic matter begins to accumulate and the site becomes drier, succession to either black spruce or white spruce will occur. The extent of the shrub cover is highly dependent on the water level. Colonization by willow and other shrubs such as dwarf and bog birch begins on the drier edges of sedge meadows and streams. This colonization expands if the water level decreases, but declines under prolonged exposure to flooded conditions. The understory species most often associated with these shrublands include wire rush, beaked sedge, water sedge, other wetland sedges, and horsetail on the wettest sites. Bluejoint, slender wheatgrass, shrubby cinquefoil, and upland sedges are found on the more mesic, better drained sites. The better drained sites often have a Bebb willow overstory. Where water sedge and/or golden moss are dominant in the understory of the Sw/Willow/Water sedge/Golden moss community, indicates a calcium-rich environment, often with stagnant water (Beckingham, 1994; MacKinnon et. al., 1992). A dominance of beaked sedge in the understory of the Basket, Flat leaved or Bebb willow dominated communities, indicates nitrogen-rich conditions with flowing water (Beckingham, 1994). Bluejoint can also be a common understory species on the better-drained sites in these community types. It appears that tufted hair grass will replace bluejoint on similar sites as elevation increases (Lane et. al., 2000).

The shrublands found adjacent to riparian areas occur on well-drained, coarse-textured soils. River alder indicates a seepage area when found on a slope as in the Yellow mountain avens-River alder/Low forb community type. Elsewhere, it grows best on poorly-drained, lower slope positions. Yellow mountain avens is a common pioneer species on gravelly river bars and rocky slopes and grows especially well on calcium-rich soils (MacKinnon et. al., 1992). Silverberry and Drummond's willow are also common in these riparian areas. Both these species prefer well-drained, coarsetextured soils. The riparian shrublands described here will eventually succeed to white spruce in the absence of disturbance.

Increased grazing pressure tends to allow Kentucky bluegrass and timothy to invade the understory of many of these shrub dominated communities. The high moisture and nutrient content of these sites makes them very productive for livestock grazing. 


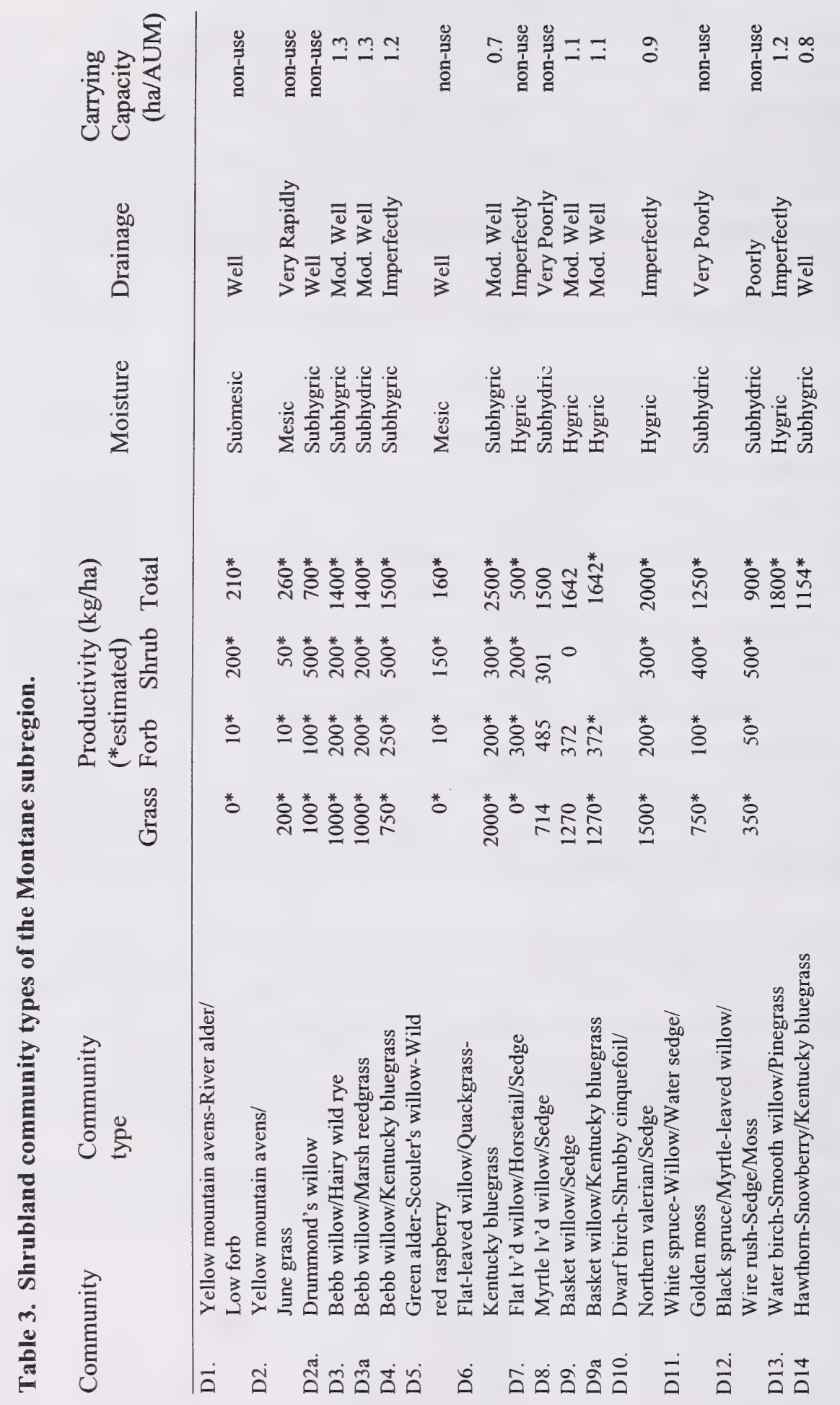




\section{Montane shrublands key}

1. Upland shrublands.. 2

Lowland or Riparian shrublands.....

2. Site is found at high elevations in upland depressions. Protection from the prevailing winds, and high moisture and nutrient regimes lead to a shrub dominated community. Trees may develop on the drier edges. Water birch is dominant.

Water birch-Smooth willow/Pinegrass $\underline{\mathrm{d} 13}$

Green alder, Bebb willow or Hawthorn dominated 3

3. Site is a seepage area on moderate northerly slopes found on mesic to hygric lower subalpine sites..

Bebb willow or Hawthorn dominated.

Green alder-Scouler's Willow-Wild red raspberry $\underline{\mathrm{d} 5}$

4. Site is altered by grazing as indicated by the presence of Timothy and Nettle and is found close to Aspen forests. Bebb Willow/Kentucky bluegrass

Drier upland shrub type found on ravines and seepage areas. Sited dominated by Bebb willow or

4a Hawthorn, snowberry dominated site

Bebb willow, hairy wildrye dominated site

5. Lowland, depressional areas.

Riparian areas adjacent to streams and rivers

6. Site undergoing succession to conifer forest, $\mathrm{Sw}, \mathrm{Sb}$ present

Wet sites dominated by willow or dwarf birch, maybe grazed.
Hawthorn-Snowberry/K. bluegrass d14

Bebb willow/Hairy wildrye $\underline{\mathrm{d} 3}$

7. Boggy sites with black spruce( $\mathrm{Sb}$ ) Drier sites with white spruce (Sw)

.Sb/Myrtle Iv'd willow/wire rush-Sedge/Moss $\underline{\mathrm{d} 12}$ Sw/Willow/Sedge/Golden moss d11

8. Drier sites dominated by dwarf birch...... Dwarf birch-Shrubby cinquefoil/Northern valerian/Sedge d10 Wet sites willow dominated, also include grazed willow sites.

9. Myrtle leaved willow dominated sites...

Myrtle leaved willow/Sedge $\underline{\mathrm{d} 8}$

Sites dominated by Flat leaved, Basket or Bebb willow.

10. Flat leaved willow dominated sites.

Bebb willow or Basket willow dominated sites

10a Grazed site with Kentucky bluegrass or Quackgrass dominated understory

..Flat lv'd willow/K. bluegrass $\underline{\mathrm{d} 6}$

Ungrazed site with sedge dominated understory.

.Flat lv'd willow/Sedge $\underline{\mathrm{d} 7}$

10b.Bebb willow dominated...

Basket willow dominated

10c Grazed Bebb willow type, K. bluegrass in understory..... Ungrazed Bebb willow type, sedge dominated understory.

Bebb willow/Kentucky bluegrass $\underline{\mathrm{d} 4}$

Bebb willow/Marsh reedgrass $\underline{\mathrm{d} 3 \mathrm{a}}$

10d Ungrazed Basket willow site, with sedge dominated understory Basket willow/Sedge $\underline{d 9}$ Grazed Basket willow site, K. bluegrass dominated understory..... Basket willow/Kentucky bluegrass $\underline{\mathbf{d} 9 \mathrm{a}}$

11. Willow shrubland adjacent to rivers and streams on coarse textured soils.... Drummond's willow d2a Yellow mountain avens dominated gravelly river flats.

12. Site is on a moist, open south facing slope with a few Balsam poplar trees. Site is found up slope from the $d 2$ community type. River alder is abundant Yellow mountain avens-River alder/Low forb $\underline{\mathrm{d} l}$ Site is dry gravelly river flats with nutrient poor soils. Junegrass is abundant.

Yellow mountain avens/Junegrass $\underline{\mathrm{d} 2}$ 

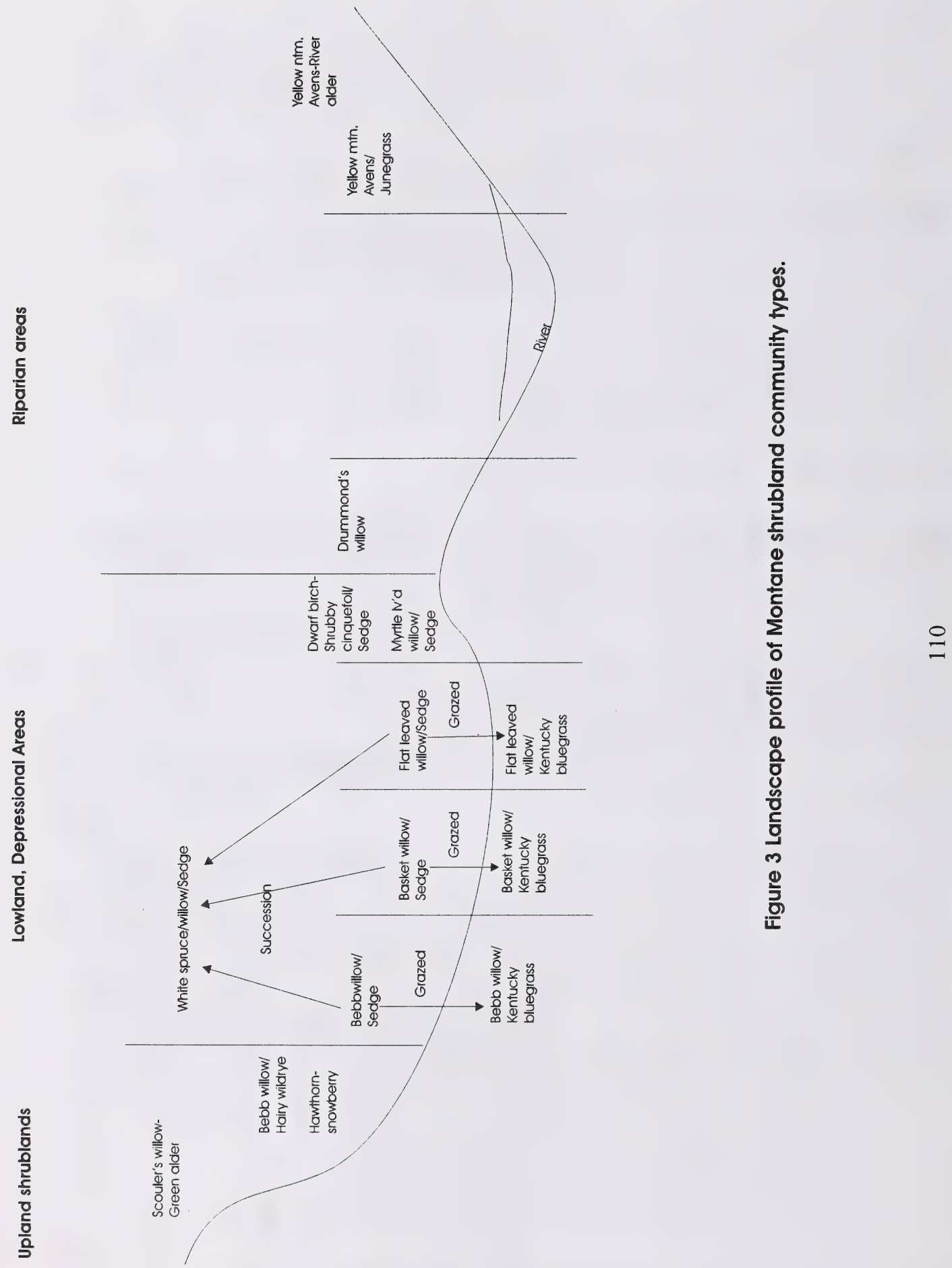

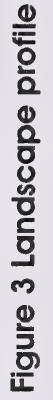




\section{SHRUBLAND COMMUNITY TYPES}

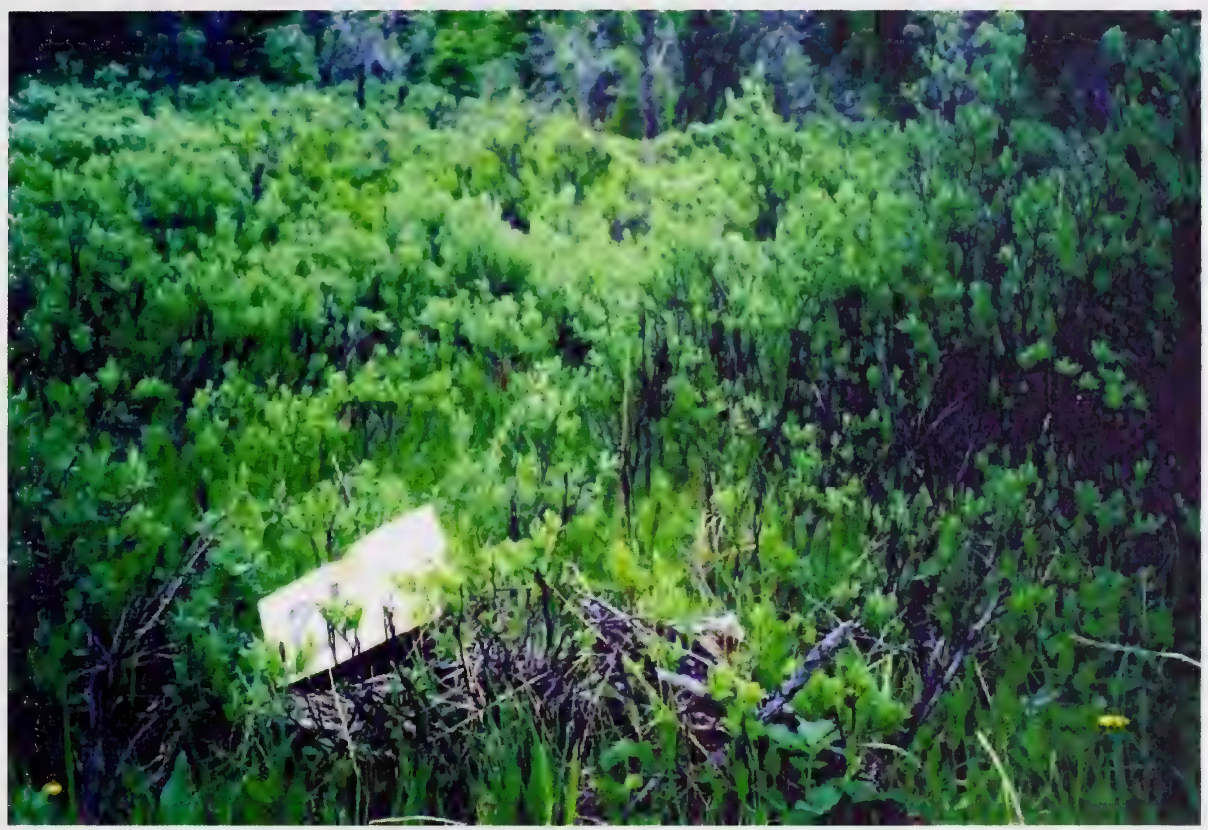

Photo 7: This photo represents a Basket willow/Sedge community type. These shrublands are found in valley depressions and are wet for much of the year. They provide excellent browse for wildlife. 


\section{D1. Yellow Mountain Avens-River Alder/ Low Forb (Dryas drummondii-Alnus tenuifolia/Low forb)}

$\mathbf{n}=\mathbf{1}$ This community type is found on an open, south-facing slope which supports a few scattered balsam poplar trees. The abundance of river alder and presence of balsam poplar indicates that this is a moist, nutrient-rich seep. In contrast yellow mountain avens grows favorably on open, well-drained sites and is typical of dry, gravelly river flats throughout Alberta. Willoughby (2001) described a Balsam poplar-White spruce/Willow/Yellow mtn. avens community type that is similar, but successionally more maturein the Upper Foothills subregion. In the absence of disturbance, river alder and balsam poplar will increase causing mountain avens to decrease as the site becomes shaded. Eventually this site will succeed to white spruce forest. This community type would be found upslope from the Yellow mtn. avens-Silverberry/Junegrass community type (D2) which is found on the level river flats.

\section{PLANT COMPOSITION CANOPY COVER (\%) MEAN RANGE CONST.}

\section{TREES}

BALSAM POPLAR

$$
5
$$

\section{SHRUBS}

WHITE SPRUCE SEEDLINGS

(Picea glauca) 3

LODGEPOLE PINE SEEDLINGS

(Pinus contorta) $\quad 1$

RIVER ALDER

(Alnus tenuifolia)

DWARF SHRUBS
YELLOW MTN. AVENS

(Dryas drummondii)

\section{FORBS}

COMMON YARROW

(Achillea millefolium)

LINDLEY'S ASTER

(Aster ciliolatus)

DANDELION

(Taraxacum officinale) $\quad 1 \quad-\quad 100$

\section{ENVIRONMENTAL VARIABLES}

MOISTURE REGIME:

SUBMESIC

NUTRIENT REGIME:

MESOTROPHIC

ELEVATION:

$1210 \mathrm{M}$

ASPECT:

SOUTHWEST

SLOPE:

$10 \%$

SOIL DRAINAGE:

WELL

\section{Forage ProduCtion (KG/HA)}

$\begin{array}{lc}\text { GRASS } & 0 \\ \text { FORBS } & 10 \\ \text { SHRUBS } & 200 \\ \text { TOTAL } & 210 \text { *ESTIMATE }\end{array}$

SUGGESTED GRAZING CAPACITY NON-USE 


\section{D2: Yellow Mountain Avens/Junegrass \\ (Dryas drummondii/Koeleria macrantha)}

$\mathbf{n}=\mathbf{2}$ This community type is typical of dry, gravelly river flats with nutrient poor soils. Mountain avens, silverberry, bearberry, juniper and junegrass are all characteristic of dry, rapidly-drained soils. Willoughby (2001) also describe a similar community type on dry, gravelly, well-drained river flats in the Upper Foothills Subregion. The poor soil conditions limits the forage productivity and amount of regrowth after grazing. This community type should be rated as secondary or non-use range.

\section{PLANT COMPOSITION CANOPY COVER (\%)} MEAN RANGe CONST.

\section{TREeS}

WHITE SPRUCE

(Picea glauca)

TREMBLING ASPEN

(Populus tremuloides) $\quad 1 \quad 0-1 \quad 50$

\section{SHRUBS}

SILVERBERRY

(Elaeagnus commutata) $5 \quad 0-10 \quad 50$

CREEPING JUNIPER

(Juniperus horizontalis) $\quad 1 \quad 0-1 \quad 50$

SHRUBBY CINQUEFOIL

(Potentilla fruticosa) $\quad 2 \quad 1-3 \quad 100$

\section{DWARF SHRUBS}

YELLOW MTN. AVENS
(Dryas drummondii)

COMMON BEARBERRY

(Arctostaphylos uva-ursi)

$35 \quad 23-47 \quad 100$

$2 \quad 0-4 \quad 50$

\section{FORBS}

COMMON YARROW

(Achillea millefolium)

REFLEXED LOCO-WEED

(Oxytropis deflexa)

CUT-LEAVED ANEMONE

(Anemone multifida) $\begin{array}{lll}4 & 0-8 & 50\end{array}$

$3 \quad 0-5 \quad 50$

11100

\section{ENVIRONMENTAL VARIABLES}

MOISTURE REGIME: SUBMESIC-SUBXERIC

NUTRIENT REGIME: SUBMESOTROPHIC

ELEVATION: $1210-1848(1529) \mathrm{M}$

ASPECT: EAST

SLOPE: $1 \%$

SOIL DRAINAGE: VERY RAPIDLY

\section{FORAGE ProduCTION (KG/HA)}

$\begin{array}{ll}\text { GRASS } & 200 \\ \text { FORBS } & 10 \\ \text { SHRUBS } & 50 \\ \text { TOTAL } & 260 * \text { ESTIMATE }\end{array}$

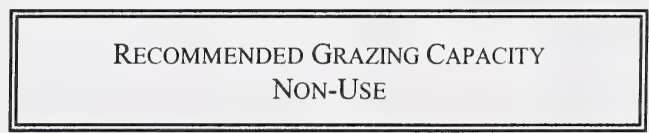

GraSSES

JUNEGRASS

(Koeleria macrantha) $\quad 21 \quad 1-40 \quad 100$

AWNLESS BROME

(Bromus inermis)

$1 \quad 0-2 \quad 50$

MARSH REED GRASS

(Calamagrostis canadensis) 1

$0-1 \quad 50$ 


\section{D2a: Drummond's willow (Salix drummondiana)}

$\mathbf{n}=1$ This community type was described next to the Oldman river on a recent river bar that is periodically flooded. Drummond's willow is well adapted to growing in a variety of soil conditions, but it prefers growing on well aerated soils. It is well adapted to growing at higher elevations and is often associated with the subalpine. Drummond's willow communities tend to be long-lived and are often maintained by frequent flooding. If the water shifts and the site drys out it will often undergo succession to a white spruce dominated forest. The dense nature of this community type often limits livestock movement. It should be rated as non-use.

PLANTCOMPOSITIONCANOPY COVER (\%) MEAN Range CONST.

\section{TREES}

BALSAM POPLAR

$\begin{array}{llll}\text { (Populus balsamifera) } & 1 & - & 100\end{array}$

\section{SHRUBS}

SILVERBERRY

(Elaeagnus commutata) $3 \quad$ - 100

DRUMMOND'S WILLOW

(Salix drummondiana) 60

MYRTLE LEAVED WILLOW

(Salix myrtillifolia)

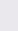

\section{ENVIRONMENTAL VARIABLES}

MOISTURE REGIME: SUBHYGRIC

NUTRIENT REGIME: PERMESOTROPHIC

ELEVATION: $1400 \mathrm{M}$

ASPECT: SOUTH

SLOPE: $1 \%$

SOIL DRAINAGE: Well

\section{FORAGE PRODUCTION (KG/HA)}

CANADA THISTLE

(Cirsium arvense)

$10 \quad-\quad 100$

MACCALLA'S ASTER

(Aster maccallae)

100

FIREWEED

(Epilobium angustifolium) 3

100

\section{GRASSES}

KENTUCKY BLUEGRASS

(Poa pratensis)
SMOOTH BROME

$10 \quad-\quad 100$

(Bromus inermis)

20

100

\begin{tabular}{ll} 
GRASS & 100 \\
FORBS & 100 \\
SHRUBS & 500 \\
TOTAL & $700 *$ ESTIMATE \\
& \\
\hline \multicolumn{2}{c}{ RECOMMENDED GRAZING CAPACITY } \\
\multicolumn{2}{c}{ NON-USE }
\end{tabular}

GRASS $\quad 100$

SHRUBS 500

NON-USE 


\section{D3: Beaked Willow/Hairy Wild Rye \\ (Salix bebbiana/Elymus innovatus)}

$\mathbf{n}=\mathbf{2}$ This community type represents a drier upland willow type which can be found on north-facing slopes, ravines and seepage areas. This community type was described in Banff and Jasper National Parks. The moisture and nutrient regimes favor an abundance of willow and the presence of a few scattered spruce trees. Beaked willow is highly palatable to wild ungulates, therefore, this community should be considered important wildlife habitat. In the absence of disturbance, this community type will likely succeed to white spruce.

\section{Plant Composition CANOPY COVER (\%) MEAN RANGe CONST.}

\section{TREES}

WHITE SPRUCE

(Picea glauca)

$3 \quad 0-5 \quad 50$

\section{SHRUBS}

\section{BEAKED WILLOW}

(Salix bebbiana)

CANADA BUFFALOBERRY

(Shepherdia canadensis)

WHITE SPRUCE SEEDLINGS

(Picea glauca)

WILlOW

(Salix spp.)

FORBS

WILD STRAWBERRY

(Fragaria virginiana)

COMMON YARROW

(Achillea millefolium)

LINDLEY'S ASTER

(Aster ciliolatus)

NORTHERN BEDSTRAW

(Galium boreale)

ALPINE HEDYSARUM

(Hedysarum alpinum)

$8 \quad 0-15 \quad 50$

$8 \quad 1-15 \quad 100$

4

3-5 $\quad 100$

$2-5 \quad 100$

\section{GraSSES}

HAIRY WILD RYE

(Elymus innovatus)

WIRE RUSH

(Juncus balticus)

BLUEGRASS

(Poa spp.)

Тімотну

(Phleum pratense)

$\begin{array}{ccc}38 & 15-60 & 100 \\ 3 & 0-5 & 50 \\ 3 & 0-5 & 50 \\ 2 & 0-3 & 50\end{array}$

$3 \quad 0-5 \quad 50$

$3 \quad 0-5 \quad 50$

$3 \quad 0-5 \quad 50$

\section{ENVIRONMENTAL VARIABLES}

MoISTURE REGIME: SUBHYGRIC

NUTRIENT REGIME: PERMESOTROPHIC

ELEVATION(mean): $1000-1060$ M (1030 M)

ASPECT: VARIABLE

SLOPE: $0-5 \%$

SOIL DRAINAGE: MODERATELY WELL

\section{Forage Production (KG/HA)}

TOTAL $1154 *$ ESTIMATE

\section{SUGGESTED GRAZING CAPACITY $1.3 \mathrm{HA} / \mathrm{AUM}$}




\section{D3a: Bebb willow/Marsh reedgrass (Salix bebbiana/Calamagrostis canadensis)}

$\mathbf{n}=\mathbf{1}$ This community type was described at Beauvais Provincial Park. It represents a mosaic of willow clumps amid a mainly graminoid matrix. In general Bebb willow is often associated with better drained soils than the Basket or Flat leaved willow dominated community types. The presence of Baltic rush and marsh reedgrass indicates that this site is better drained than the Basket and Flat leaved willow/ Sedge dominated community types described later in the guide. The open nature of this site and the drier site conditions would favour livestock use. Heavy livestock use will favour the growth of Kentucky bluegrass and timothy and would resemble the Bebb willow/Kentucky bluegrass dominated community type.

PLANT COMPOSITION CANOPY COVER (\%)

MEAN RANGE CONST.

\section{TREES}

BALSAM POPLAR

(Populus balsamifera)

SHRUBS

BEAKED WILLOW

(Salix bebbiana) $\quad 20 \quad-\quad 100$

$\begin{array}{lll}\text { MYRTLE LEAVED WILLOW } & & \\ \text { (Salix myritillifolia) } & 20 & -\end{array}$

\section{FORBS}

SWAMP HORSETAIL

(Equisetum fluviatile) $10 \quad-\quad 100$

YELLOW AVENS

(Geum aleppicum) $\quad 10 \quad-\quad 100$

Arrow leaved coltsfoot

(Petasites sagittatus) $3 \quad-\quad 100$

LYALL'S ANGELICA

(Angelica arguta)

$3 \quad-\quad 100$

\section{GRASSES}

MARSH REEDGRASS

(Calamagrostis canadensis) $10 \quad-\quad 100$

WIRE RUSH

(Juncus balticus)

WATER SEDGE

(Carex aquatilis.)
$20 \quad-\quad 100$

$10 \quad-\quad 100$

\section{ENVIRONMENTAL VARIABLES}

MoISTURE REgIme: SUBHYGRIC

Nutrient Regime: PermesotrophiC

ELEVATION(mean): $1363 \mathrm{~m}$

ASPECT: VARIABLE

SLOPE: $0-5 \%$

SOIL DRAINAGE: ModeraTELY WELL

\section{Forage ProduCtion (KG/HA)}

$\begin{array}{lc}\text { GRASS } & 1000 \\ \text { FORBS } & 200 \\ \text { SHRUBS } & 200 \\ \text { TOTAL } & 1400^{*} \text { ESTIMATE }\end{array}$

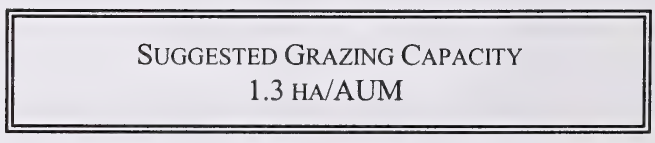




\section{D4: Bebb willow/Kentucky bluegrass (Salix bebbiana/Poa pratensis)}

$\mathbf{n = 1 0}$ This community type is very similar to the Bebb willow/Hairy wild rye or Bebb willow/Marsh reedgrass community type, however, this community type has been altered by grazing. The grazing pressure has promoted the establishment of timothy, Kentucky bluegrass and dandelion. These sites are often very productive because of the higher nutrients and moisture and once Kentucky bluegrass and timothy become established these sites will be readily grazed by livestock. In the absence of disturbance this type will likely succeed to white spruce.

\section{Plant Composition CANOpy Cover (\%)} MEAN RANGE CONST.

\section{SHRUBS}

FLAT LEAVED WILLOW

(Salix planifolia)

PRICKLY ROSE

(Rosa acicularis)

BEBB WILLOW

(Salix bebbiana)

WILD RED RASPBERRY

(Rubus idaeus)

RED-OSIER DOGWOOD

(Cornus stolonifera)

\section{FORBS}

NETTLE

(Urtica spp.)

WILD VETCH

(Vicia americana)

DANDELION

(Taraxacum officinale)

HORSETAIL

(Equisetum arvense)

\section{Grasses}

TIMOTHY

(Phleum pratense)

KENTUCKY BLUEGRASS

(Poa pratensis)

SMOOTH BROME

(Bromus inermis)

\section{$5 \quad 0-20 \quad 44$}

$1 \quad 0-3 \quad 56$

$41 \quad 10-80 \quad 100$

$1 \quad 0-10 \quad 33$

$1 \quad 0-3 \quad 33$

$\begin{array}{lll}4 & 0-25 \quad 33\end{array}$

$2 \quad 0-6 \quad 89$

$\begin{array}{lll}5 & 0-20 & 89\end{array}$

$3 \quad 0-10 \quad 57$

$\begin{array}{lll}15 & 0-50 & 89 \\ 4 & 0-40 & 89 \\ 11 & 0-80 & 33\end{array}$

\section{ENVIRONMENTAL VARIABLES}

MOISTURE REGIME: SUBHYGRIC

NUTRIENT REGIME: PERMESOTROPHIC

ELEVATION: 1411(1218-1510) M

SOIL DRAINAGE: IMPERFECTLY

Forage Production (KG/HA)

$\begin{array}{lc}\text { GRASS } & 750 \\ \text { FORBS } & 250 \\ \text { SHRUB } & 500 \\ \text { TOTAL } & 1500 * \text { ESTIMATE }\end{array}$

SUGGESTED GRAZING CAPACITY

$1.2 \mathrm{HA} / \mathrm{AUM}$ 


\section{D5: Green Alder-Scouler's Willow-Wild Red Raspberry (Alnus crispa-Salix scouleriana-Rubus idaeus)}

$\mathbf{n}=\mathbf{2}$ This community type is generally found on mesic to hygric lower subalpine sites on moderate northerly slopes. Soils are moderately well to well-drained on morainal landfr.rms with the community occurring in seepage areas (Corns and Achuff, 1982). This type is similar to Jaques and Corbin's (1981) Scouler's willow-Beaked willow type. It is also comparable to the Willow-Alder-Low bush cranberry/Shield fern type described by Lane et al. (2000) in the Lower Foothills subregion on similar site types. Salix scouleriana dominates the overstory and alder makes up a major portion of the understory cover. Dominance of alder may indicate a recent fire or other disturbance in the understory since alder regenerates faster than Salix scouleriana. White spruce, aspen, balsam poplar and lodgepole pine can often be found to regenerate in this community type, therefore this community type will likely succeed to white spruce (Corns and Achuff, 1982).

\section{PLANT COMPOSITION CANOPY COVER (\%)} MEAN RANGe CONST.

\section{SHRUBS}

GREEN ALDER

(Alnus crispa)

SCOULER'S WILLOW

(Salix scouleriana)

WILD RED RASPBERRY

(Rubus idaeus)

PRICKLY ROSE

(Rosa acicularis)

\section{FORBS}

VEINY MEADOW RUE

(Thalictrum venulosum)

WESTERN CANADA VIOLET

(Viola canadensis)

RED AND WHITE BANEBERRY

(Actaea rubra)

BUNCHBERRY

(Cornus canadensis)

$\begin{array}{lll}43 & 5-80 & 100 \\ 35 & 10-60 & 100 \\ 21 & 1-40 & 100 \\ 8 & 0-15 & 50\end{array}$

GRASSES

HAIRY WILD RYE

(Elymus innovatus)

MARSH REEDGRASS

(Calamagrostis canadensis) 3

\section{ENVIRONMENTAL VARIABLES}

MoISTURE REGIME: MeSIC TO SUBHYGRIC

NUTRIENT REGIME: MESOTROPHIC TO

PERMESOTROPHIC

ELEVATION(MEAN): 1270-1580 M (1425 M)

ASPECT: NORTHERLY

SLOPE: $12-75 \%$

SOIL DRAINAGE: WELL

Forage Production (KG/HA)

$\begin{array}{lc}\text { GRASS } & 0 \\ \text { FORBS } & 10 \\ \text { SHRUBS } & 150 \\ \text { TOTAL } & 160 * \text { ESTIMATE }\end{array}$

SUGgested GRAZING CAPACITY

NON-USE 


\section{D6: Flat-Leaved Willow/Quackgrass-Kentucky Bluegrass \\ (Salix planifolia/Agropyron repens-Poa spp.)}

$\mathbf{n}=2$ This community type represents a disturbed willow shrubland. Salix planifolia prefers areas where the water table is shallow, and is found adjacent to riparian areas, fens, swamps and lakeshores. Heavy grazing of this type has affected the understory vegetation allowing an increase in quackgrass and Kentucky bluegrass on the drier areas. The proximity to water and shallow water table would explain the heavy use by livestock as well as the high production. Care must be taken to ensure that the riparian habitat is not over-used by livestock.

\section{PLANT COMPOSITION CANOPY COVER (\%) MEAN RANGe CONST.}

\section{SHRUBS}

FLAT-LEAVED WILLOW

(Salix planifolia)

DWARF BIRCH

(Betula pumila)

\section{FORBS}

MARSH VIOLET

(Viola palustris)

RUSH ASTER

(Aster borealis)

\section{GRASSES}

QUACKGRASS

(Agropyron repens)

(Poa pratensis)

BLUE GRASS

(Poa spp.)

GREEN SEDGE

(Carex viridula)

ALPINE RUSH

(Juncus alpinus)

BEAKED SEDGE

(Carex rostrata)

$41 \quad 25-56 \quad 100$

$1 \quad 0-1 \quad 50$

$3 \quad 0-6 \quad 50$

$2 \quad 0-3 \quad 50$

$18 \quad 0-35 \quad 50$

$18 \quad 0-35 \quad 50$

$9 \quad 0-17 \quad 50$

$\begin{array}{lll}4 & 0-7 & 50\end{array}$

$\begin{array}{lll}4 & 0-7 & 50\end{array}$

$2 \quad 0-3 \quad 50$

\section{ENVIRONMENTAL VARIABLES}

Moisture Regime: Mesic to Hygric

NUtRIENT REGIME: MESOTROPHIC TO

PERMESOTROPHIC

ELEVATION(MEAN): 990-1160 M (1075 M)

SOIL DRAINAGE: WeLl TO POORLY

Forage ProduCtion (KG/HA)

$\begin{array}{lc}\text { GRASS } & 2000 \\ \text { FORBS } & 200 \\ \text { SHRUB } & 300 \\ \text { TOTAL } & 250{ }^{*} \text { ESTIMATE }\end{array}$

SugGESTED GRAZING CAPACITY

$0.7 \mathrm{HA} / \mathrm{AUM}$ 


\section{D7: Flat leaved willow/Horsetail/Sedge (Salix planifolia/Equisetum arvense/Carex spp.)}

$\mathbf{n}=6$ This is a highly unusual community type for the montane. It will likely only be found at the lower elevational limits of the montane subregion. Corns and Achuff(1982) describe this community type on hygric, level to gently sloping fluvial landforms of various aspects. The soils are imperfectly to poorly drained and are subject to periodic flooding and sediment deposition. Tree cover is absent and willow cover is high. Field horsetail is the dominant herb. Other species may also be found, such as dwarf shrubs and sedges, however, these are minor components.

\section{PLANT COMPOSITION CANOPY COVER (\%) \\ MEAN RANGe CONST.}

\section{SHRUBS}

FLAT LEAVED WILLOW

(Salix planifolia)

RED-OSIER DOGWOOD

(Cornus stolonifera)

Bebb willow

(Salix bebbiana)

MYRTLE LEAVED WILLOW

(Salix myrtillifolia)

8

33

$20-40 \quad 100$

$1 \quad 0-3 \quad 33$

$7 \quad 0-20 \quad 83$

$8 \quad 0-20 \quad 83$

\section{FORBS}

FIELD HORSETAIL

(Equisetum arvense)

FIREWEED

(Epilobium angustifolium) 4

LARGE LEAVED AVENS

(Geum macrophyllum)

LYALL'S ANGELICA

(Angelica arguta)

14

$1-40$

100

$0-20 \quad 67$

GraminoIDS

BEAKED SEDGE

(Carex rostrata)

KENTUCKY BLUEGRASS

(Poa pratensis)
2

$0-10 \quad 50$

$2 \quad 0-10 \quad 50$

$1 \quad 0-3 \quad 67$

0-10 67

$2 \quad 0-10 \quad 50$

\section{ENVIRONMENTAL VARIABLES}

MOISTURE REGIME: HYGRIC

Nutrient Regime: Permesotrophic

ELEVATION: 1315(980-1420) M

SOIL DRAINAGE: IMPERFECTLY

Forage Production (KG/HA)

\begin{tabular}{ll} 
GRASS & \multicolumn{1}{c}{0} \\
FORBS & 300 \\
SHRUB & 200 \\
TOTAL & $50 *^{*}$ ESTIMATE
\end{tabular}

SUGgESTED GRAZING CAPACITY NON-USE 


\section{D8: Myrtle leaved willow/Sedge \\ (Salix myrtillifolia/Carex rostrata)}

$\mathbf{n = 1 2}$ This community type is similar to the Willow-Bog birch/Sedge community type of Lane et al (2000). It represents a typical willow/sedge community type found on wet, poorly drained soils. There are numerous different species of willow as a result of the open canopy and the wet moisture regime. A high cover of beaked sedge indicates a nitrogen-rich environment where the water is moving. Tufted hair grass (Deschampsia cespitosa) will replace marsh reedgrass in this community type at higher elevations (Lane et al, 2000). This would be considered an edaphic climax community since the area is frequently flooded which prevents establishment of trees although it may be found in association with black spruce and black spruce-larch community types. This community type would be considered non-use for livestock due to the poor access caused by the wet substrate.

\section{PLANT COMPOSITION CANOPY COVER (\%)} MEAN Range Const.

\section{SHRUBS}

MYRTLE LEAVED WILLOW

(Salix spp.)

BOG BIRCH 34 $5-86$ 100
(Betula glandulosa)

SHRUBBY WILLOW

(Salix arbusculoides)

\section{FORBS}

ARROW-LEAVED COLTSFOOT

(Petasites saggitatus) 2

LARGE-LEAVED AVENS

(Geum macrophyllum)

2

LINDLEYS ASTER

(Aster ciliolatus)

STRAWBERRY

(Fragaria virginiana)

12

0-32

50

1

$0-8$

\section{GRASSES}

SEDGE

(Carex rostrata, C. aquatilis) $26 \quad 3-70 \quad 100$

MARSH REEDGRASS

(Calamagrostis canadensis) 4

WIRE RUSH

(Juncus balticus)

$\begin{array}{lll}0-18 & 18\end{array}$

$3 \quad 0-13 \quad 58$

$2 \quad 0-12 \quad 42$

$0-22 \quad 33$

$0-18 \quad 67$
$0-13 \quad 17$

\section{ENVIRONMENTAL VARIABLES}

MOISTURE REGIME: HYDRIC-HYGRIC

NUTRIENT REGIME : MESOTROPHIC-

PERMESOTROPHIC

ELEVATION(MEAN): 1241-1524(1450) M

SOIL DRAINAGE: IMPERFECTLY- VERY POORLY

\section{Forage Production (KG/HA)}

$\begin{array}{ll}\text { GRASS } & 714(422-1132) \\ \text { FORBS } & 485(24-1818) \\ \text { SHRUB } & 301(204-710) \\ \text { TOTAL } & 1500(740-2522)\end{array}$

SUGGESTED GRAZING CAPACITY NON-USE 


\section{D9: Basket Willow/Sedge \\ (Salix petiolaris/Carex spp.)}

$\mathbf{n}=3$ Basket willow prefers growing on well to moderately-well drained soils. The soils of this community type tend to be drier than the Myrtle leaved and Flat leaved willow community types, but are wetter than the Bebb willow dominated types. Basket willow is not particularly palatable to wild ungulates, however the understory shrubs and forbs can provide a substantial amount of forage. Heavy grazing of this community type will allow Kentucky bluegrass and timothy to invade to form the Basket willow/Kentucky bluegrass dominated community type

PLANT COMPOSITION CANOPY COVER (\%) MEAN RANGe CONST.

\section{SHRUBS}

BOG BIRCH

$\begin{array}{llll}\text { (Betula glandulosa) } & 13 & 0-23 & 67\end{array}$

BASKET WILLOW

(Salix petiolaris)

SHRUBBY CINQUEFOIL

(Potentilla fruticosa) $\quad 3 \quad 0-9 \quad 67$

HOARY WILLOW

(Salix candida)

FORBS

VEINY MEADOW RUE

$\begin{array}{llll}\text { (Thalictrum venulosum) } \quad 5 & 2-8 & 100\end{array}$

FIREWEED

(Epilobium angustifolium) 2

PURPLE AVENS

(Geum rivale)

SMOOTH ASTER

(Aster laevis)

GRASSES

WIRE RUSH

(Juncus balticus)

BEAKED SEDGE

(Carex rostrata)

GRACEFUL SEDGE

(Carex praegracilis)

SLENDER WHEATGRASS

(Agropyron trachycaulum)

MARSH REEDGRASS

(Calamagrostis canadensis)2

$2-2 \quad 100$

$2 \quad 0-5 \quad 33$

$5 \quad 0-15 \quad 33$

\section{ENVIRONMENTAL VARIABLES}

MoISTURE REGIME: MesiC TO SUBHydRIC

NUTRIENT REGIME : MESOTROPHIC TO

PERMESOTROPHIC

ELEVATION: $1440 \mathrm{M}$

SLOPE: $0-6 \%$

ASPECT: NORTHERLY

SOIL DRAINAGE: WELL TO POORLY

Forage PRODUCTION (KG/HA)

$\begin{array}{lr}\text { GRASS } & 1270 \\ \text { FORBS } & 372 \\ \text { SHRUB } & 0 \\ \text { TOTAL } & 1642\end{array}$

SUGGESTED GRAZING CAPACITY $1.1 \mathrm{HA} / \mathrm{AUM}$ 


\section{D9a: Basket Willow/Kentucky bluegrass \\ (Salix petiolaris/Poa pratensis)}

$\mathbf{n}=\mathbf{1}$ This community type represents a grazing disclimax of the Basket willow/Sedge dominated community type. Basket willow is not particularly palatable to livestock, but heavy grazing of the understory will allow Kentucky bluegrass and timothy to invade. Once established these introduced species are very palatable to livestock and this community type would be extensively utilized by livestock because of the high moisture and nutrients on the site.

\section{PLANT COMPOSITION CANOPY COVER (\%) MEAN RANGE CONST.}

\section{SHRUBS}

BOG BIRCH

(Betula glandulosa)

(Salix petiolaris)

Flat leaved willow

(Salix planifolia)

FORBS

CANADA THISTLE

(Cirsium arvense)

DANDELION

(Taraxacum officinale)

LARGE LEAVED AVENS

(Geum macrophyllum)

SMOOTH ASTER

(Aster laevis)

GRASSES

BEAKED SEDGE

(Carex rostrata)

KENTUCKY BLUEGRASS

(Poa pratensis)
$1 \quad-$

100

$70 \quad-\quad 100$

$3 \quad-\quad 100$

100

100

10

100

$10 \quad-\quad 100$

$10 \quad-\quad 100$

20

100

\section{ENVIRONMENTAL VARIABLES}

MOISTURE REGIME: SUBHYDRIC

Nutrient Regime : PermesotrophiC

ELEVATION: $1410 \mathrm{M}$

SLOPE: $2 \%$

ASPECT: NORTHERLY

SOIL DRAINAGE: MOD. WELL

Forage Production (KG/HA)

$\begin{array}{lc}\text { GRASS } & 1270 \\ \text { FORBS } & 372 \\ \text { SHRUB } & 0 \\ \text { TOTAL } & 1642 * \text { ESTIMATE }\end{array}$

SUGGESTED GRAZING CAPACITY

$1.1 \mathrm{HA} / \mathrm{AUM}$ 


\section{D10: Dwarf Birch-Shrubby Cinquefoil/Northern Valerian/Sedge (Betula pumila-Potentilla fruticosa/Valeriana dioica/Carex spp.)}

$\mathbf{n}=\mathbf{2}$ This community type occurs on hummocky terrain. On wet, marshy sites, Betula pumila, Salix glauca, Salix maccalliana and Carex aquatilis are found. On the drier, subhygric hummocks, grassy open areas are dominated by Potentilla fruticosa, Deschampsia cespitosa, and Elymus innovatus. The drier hummocks would be the only areas useful for domestic livestock,but may be difficult to access if the low areas are flooded. Therefore, this community type should be considered secondary range for domestic livestock.

\section{Plant COMPOSITION CANOPY COVER (\%) MEAN RANGe CONST.}

\section{SHRUBS}

DWARF BIRCH

(Betula pumila)

SHRUBBY CINQUEFOIL

(Potentilla fruticosa)

SMOOTH WILLOW

(Salix glauca)

VELVET-FRUITED WILLOW

(Salix maccalliana)

\section{FORBS}

NORTHERN VALERIAN

(Valeriana dioica)

SHOWY EVERLASTING

(Antennaria pulcherrima)

FIREWEED

(Epilobium angustifolium)

NORTHERN BEDSTRAW

(Galium boreale)

ELEPHANT'S HEAD

(Pedicularis groenlandica) $3 \quad 0-5 \quad 50$

\section{GRASSES}

HAIRY WILD RYE

(Elymus innovatus)

SEDGE

(Carex spp.)

$23 \quad 20-25 \quad 100$

$18 \quad 15-20 \quad 100$

$13 \quad 10-15 \quad 100$

$15 \quad 0-30 \quad 50$

TUFTED HAIR GRASS

(Deschampsia cespitosa)

RUSH-LIKE SEDGE

(Carex scirpoidea)

WATER SEDGE

(Carex aquatilis)

$\begin{array}{ccc}5 & 2-8 & 100 \\ 1 & 1 & 100 \\ 1 & 1 & 100 \\ 1 & 1 & 100 \\ 3 & 0-5 & 50\end{array}$

\section{ENVIRONMENTAL VARIABLES}

MOISTURE REGIME: SUBHYGRIC TO

SUBHYDRIC

Nutrient REgIME: PERMESOTROPHIC

ELEVATION(MEAN): 1390-1440 M (1415 M)

SOIL DRAINAGE: IMPERFECTLY TO POORLY

Forage Production (KG/HA)

$\begin{array}{lc}\text { GRASS } & 1500 \\ \text { FORBS } & 200 \\ \text { SHRUB } & 300 \\ \text { TOTAL } & 2000 * \text { ESTIMATE }\end{array}$

SUGGESTED GRAZING CAPACITY

$0.9 \mathrm{HA} / \mathrm{AUM}$ 


\section{D11: White Spruce-Willow/Water Sedge/Golden Moss (Picea glauca-Salix spp./Carex aquatilis/Tomenthypnum nitens)}

$\mathbf{n}=\mathbf{2}$ This community type represents a wet willow shrubland succeeding to white spruce. The high water sedge and golden moss cover indicates a calcium-rich environment (Beckingham, 1994; MacKinnon et al., 1992). As organic matter accumulates and the site becomes drier, willow and spruce will increase in cover. This community would be considered non-use for domestic livestock, however, Salix arbusculoides and Salix bebbiana are very palatable to wild ungulates, therefore, this type could be considered important wildlife habitat.

Plant Composition CANOPy COVER (\%)

\section{MEAN RANGE CONST.}

\section{SHRUBS}

WHITE SPRUCE SEEDLINGS

(Picea glauca)

SHRUBBY WILLOW

(Salix arbusculoides) $\quad 18 \quad 0-35 \quad 50$

DWARF BIRCH

(Betula pumila)

BEAKED WILLOW

(Salix bebbiana)

COMMON LABRADOR TEA

(Ledum groenlandicum) 2

LODGEPOLE PINE SEEDLINGS

(Pinus contorta)

$2 \quad 1-4 \quad 100$

$0-8-20$

$\begin{array}{lll}4 & 0-8 & 50\end{array}$

$4 \quad 0-8 \quad 50$

FORBS

RUSH ASTER

(Aster borealis)

WILD STRAWBERRY

(Fragaria virginiana) $\quad 1 \quad 1 \quad 100$

SWAMP HORSETAIL

(Equisetum fluviatile) $\quad 10 \quad 0-20 \quad 50$

DEWBERRY

(Rubus pubescens) $\quad 1 \quad 0-2 \quad 50$

GRASSES

WATER SEDGE

(Carex aquatilis)

BEAKED SEDGE

(Carex rostrata)

$0-3 \quad 50$

$0-2 \quad 50$

MARSH REEDGRASS

(Calamagrostis canadensis) $1 \quad 0-1 \quad 50$

\section{MOSSES}

GOLDEN MOSS

(Tomenthypnum nitens)

RUSTY PEAT MOSS

(Sphagnum fuscum)
$42 \quad 18-65 \quad 100$

$8 \quad 0-15 \quad 50$

\section{ENVIRONMENTAL VARIABLES}

MOISTURE REGIME: SUBHYDRIC

NUTRIENT REGIME: EUTROPHIC

ELEVATION: $1240 \mathrm{M}$

ASPECT: VARIABLE

SLOPE: $0-2 \%$

SOIL DRAINAGE: VERY POORLY

Forage Production (KG/Ha)

$\begin{array}{lc}\text { GRASS } & 750 \\ \text { FORBS } & 100 \\ \text { SHRUB } & 400 \\ \text { TOTAL } & 1250 * \text { ESTIMATE }\end{array}$

SUGGESTED GRAZING CAPACITY NON-USE 


\section{D12: Black Spruce/Myrtle-Leaved Willow/Wire Rush-Sedge/Moss (Picea mariana/Salix myrtillifolia/Juncus balticus-Carex spp./Moss spp.)}

$\mathbf{n = 3}$ This community type represents a wet willow shrubland succeeding to black spruce. It is most simlar to the Bog birch-Basket willow-Myrtle-leaved willow community type (D9), however this one is successionally more advanced. Salix myrtillifolia is characteristic of mossy bogs, muskegs and moist conifer forests (Jaques and Corbin, 1981). This would be considered non-use for domestic livestock and wildlife because Salix myrtillifolia is generally unpalatable.

PLANT COMPOSITION CANOPY COVER (\%) MEAN RANGE CONST.

\section{TREES}

BLACK SPRUCE

(Picea mariana)

$7 \quad 0-10 \quad 67$

\section{SHRUBS}

BLACK SPRUCE SEEDLINGS

(Picea mariana)

LABRADOR TEA

(Ledum groenlandicum)

MYRTLE-LEAVED WILLOW

(Salix myrtillifolia)

SHRUBBY CINQUEFOIL

(Potentilla fruticosa)

DWARF BIRCH

(Betula pumila)

PRICKLY ROSE

(Rose acicularis)

$15 \quad 1-40$

100

$3 \quad 1-5 \quad 100$

$25 \quad 0-50 \quad 67$

$4 \quad 0-10 \quad 67$

$3 \quad 0-5 \quad 67$

\section{FORBS}

DWARF SCOURING RUSH

(Equisetum scirpoides)

NORTHERN BED STRAW

(Galium boreale)$$
2
$$

$2 \quad 0-5$

67

$0-2$

67

\section{GraSSES}

WIRE RUSH

(Juncus balticus)

SHEATHED SEDGE

(Carex vaginata)

HAIR-LIKE SEDGE

(Carex capillaris)

NEBRASKA SEDGE

(Carex nebraskensis)

$\begin{array}{lll}14 & 1-30 & 100 \\ 15 & 0-40 & 67 \\ 2 & 0-3 & 67 \\ 5 & 0-15 & 33\end{array}$

Mosses

GOLDEN MOSS

(Tomenthypnum nitens)
TUFTED MOSS

(Aulacomnium palustre) $4 \quad 0-10 \quad 67$

BROWN MOSS

(Drepanocladus revolvens) $7 \quad 0-20 \quad 67$

\section{ENVIRONMENTAL VARIABLES}

MOISTURE REGIME: SUBHYGRIC TO SUBHYDRIC

Nutrient Regime: Permesotrophic

ELEVATION(MEAN): 1290-1300 M (1295 M)

SOIL DRAINAGE: POORLY

Forage ProduCtion (KG/HA)

$\begin{array}{lc}\text { GRASS } & 350 \\ \text { FORBS } & 50 \\ \text { SHRUB } & 500 \\ \text { TOTAL } & 900 * \text { ESTIMATE }\end{array}$

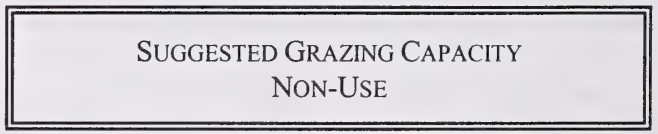




\section{D13: Water birch-Smooth willow/Pinegrass \\ (Betula occidentale-Salix glauca/Calamagrostis rubescens)}

$\mathbf{n}=1$ This community was described on a hilltop depression which supports a high moisture and nutrient regime. The depression also provides protection from the prevailing winds. Therefore, shrubs are abundant, however, due to wet conditions at the bottom of the depression, trees will likely only develop on the drier edges.

The surrounding wind-exposed areas support grassland vegetation, therefore, this community type would provide good shelter for livestock later in the fall when the site had dried.

\section{PLANT COMPOSITION CANOPY COVER (\%)} MEAN RANGE CONST.

\section{SHRUBS}

BRACTED HONEYSUCKLE

(Lonicer involcrata) $\quad 6 \quad-\quad 100$

WATER BIRCH

$\begin{array}{llll}\text { (Betula occidentale) } & 21 \quad & - & 100\end{array}$

SMOOTH WILLOW

(Salix glauca)

$21 \quad 100$

SNOWBERRY

(Symphoricarpos occidentalis) 15 -

100

FORBS

SHOWY ASTER

(Aster conspicuus.

STRAWBERRY

$\begin{array}{llll}\text { (Fragaria virginiana) } & 8 & - & 100\end{array}$

WINTERGREEN

$\begin{array}{llll}\text { (Pyrola asarifolia) } & 7 & - & 100\end{array}$

SMOOTH ASTER

(Aster laevis)

\section{ENVIRONMENTAL VARIABLES}

MoISTURE REGIME: SUBHYGRIC

Nutrient RegIME: PermesotrophiC

ELEVATION: 1600 M

SOIL DRAINAGE: POORLY

Forage Production (KG/Ha)

TOTAL $1500 *$ ESTIMATE

SUGGESTED GRAZING CAPACITY

$1.2 \mathrm{HA} / \mathrm{AUM}$

GRASSES

PINEGRASS

(Calamagrostis rubescens) $15 \quad-\quad 100$

PRAIRIE SEDGE

(Carex prairea)

$1 \quad-\quad 100$




\section{D13: Hawthorn-Snowberry/Kentucky bluegrass \\ (Crataegus rotundifolia-Symphoricarpos albus/Poa pratensis)}

$\mathbf{n}=\mathbf{2}$ This community can be found on alluvial terraces along streams and rivers or on slopes immediately below a spring or seep (Thompson and Hansen 2002). Thompson and Hansen (2002) described this community type in the Cypress Hills, but it has been observed in the Castle and South Castle drainages. Where this community type forms dense thickets there is little use by livestock. However, severe prolonged disturbance in the more open stands can lead to the invasion of Kentucky bluegrass and timothy to form this community type.

Succession in the absence of disturbance will likely be to aspen and then white spruce.

\section{PLANT COMPOSITION CANOPY COVER (\%)} MEAN RANGE CONST.

TREES

ASPEN

(Populus tremuloides) $\quad 2 \quad 0-3 \quad 50$

\section{SHRUBS}

HAWTHORN

(Crataegus rotundifolia) $70 \quad 70-70$

PRICKLY ROSE

(Rosa acicularis)

CHOKECHERRY

(Prunus virginiana)

SNOWBERRY

(Symphoricarpos albus)

$3 \quad 3-3 \quad 100$

$5 \quad 0-10 \quad 50$

$17 \quad 3-30 \quad 100$

\section{FORBS}

COW PARSNIP

(Heracleum lanatum.) $\quad 7 \quad 3-10 \quad 100$

STRAWBERRY

(Fragaria virginiana) $\quad 3 \quad 3-3 \quad 100$

DANDELION

(Taraxacum officinale) $\quad 3 \quad 3-3 \quad 100$

AMERICAN VETCH

$\begin{array}{llll}\text { (Vicia americanum) } & 2 & 1-3 & 100\end{array}$

\section{GraSSES}

KENTUCKY BLUEGRASS

(Poa pratensis)

SPRENGEL'S SEDGE

(Carex sprengelii)

\section{ENVIRONMENTAL VARIABLES}

MOISTURE REGIME: SUBHYGRIC

Nutrient REgIME: PERMESOTROPHIC

ELEVATION: 1300(1234-1365) M

SOIL DRAINAGE: POORLY

Forage Production (KG/HA)

TOTAL $1154 *$ ESTIMATE

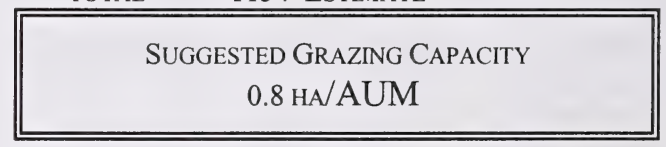




\section{MONTANE FOREST ECOLOGY}

The Montane subregion is distinguished from other subregions by having two distinct ecological sequences: Douglas-fir (Fd) and limber pine (Pf) in one sequence, and lodgepole pine(Pl) in another (Figure 4). Douglas-fir is the climax species on steep, south-facing, shallow rocky soils, and very coarse-textured outwash in valley bottoms (Strong 1992). Limber pine occupies exposed rocky outcrops where the environmental conditions are extreme. These sites are very xeric with shallow, poorly developed soils. Kuchar (1973) noted that the limber pine in Alberta is found at the northern limit of its range since it is found well below timberline. It is normally associated with high elevations or timberline south of Alberta where it takes on a krummholz form (dwarfed, contorted form, maintained by strong winds).

Closed-canopied lodgepole pine stands represent the primary reference vegetation for the montane subregion, since they often occur on mesic sites (Strong 1992). In contrast, closedcanopied aspen(Aw) stands tend to occur on sites that are warmer and drier than the reference sites (Strong 1992). Douglas-fir and white spruce(Sw) represent the potential climatic climax species for both lodgepole pine and aspen stands (Strong 1992; La Roi and Hnatiuk 1980). Balsam poplar $(\mathrm{Pb})$, however, occupies the moistest sites and will succeed to white spruce since the high moisture content is not conducive to Douglas-fir succession.

Common understory species include thimbleberry, creeping mahonia, Canada buffaloberry, bearberry, snowberry and white meadowsweet. These species tend to define the ecosites and ecosite phases as described by Archibald et al. (1996). Thimbleberry and creeping mahonia are more common in the Castle area of the province. Moving north of Blairmore in the Montane thimbleberry is often replaced by cow parsnip and creeping mahonia by white meadowsweet on similar ecosites.

Many of the forested communities at lower elevations (1400-1500 m ) in the Castle area were dominated by subalpine species (subalpine fir $(\mathrm{Fa})$, Engelmann spruce(Se)), whereas the Montane grasslands in this area were described up to elevations of $2000 \mathrm{~m}$. This resulted in a broad range of characteristic species on modal sites. Archibald et al. (1996) felt there had to be further refinement of the Subalpine subregion into upper and lower latitudinal subdivisions. Clearly, this would help to refine the classification of community types in the Castle area.

The common species, canopy cover, community characteristics and productivity are outlined. 


\section{DRYNARM}

\section{Limber Pine}

Rapidly drained

(Rocky sites)

I

Douglas-fir Rapidly and well drained Eutric Brunisols

(Coarse soils and steep south aspects!

1

Open Lodgepole Pine

Rapidly to well drained Eutric Brunisols

(Coarse soils)
Fescue

Well drained

Black Chernozems

(Southern areas)

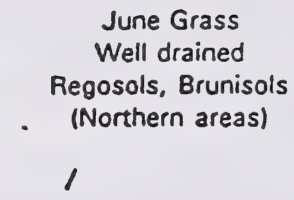

Aspen

Moderately well drained

Gray Luvisols, Eutric Brunisols

(Successional to White Spruce and Douglas-fir)

1

Lodgepole Pine

Moderately well drained

Gray Luvisols, Eutric Brunisols (Successional to White Spruce and Douglas-fir)

1

Balsam Poplar

Imperfectly drained

Gleysols, Regosols

I

Willows

Imperfectly to poorly drained

Gleysols, Regosols

WET/COOL

Figure 4: Ecological sequence of the plant communities in the Montane subregion along an environmental gradient (Strong 1992) 


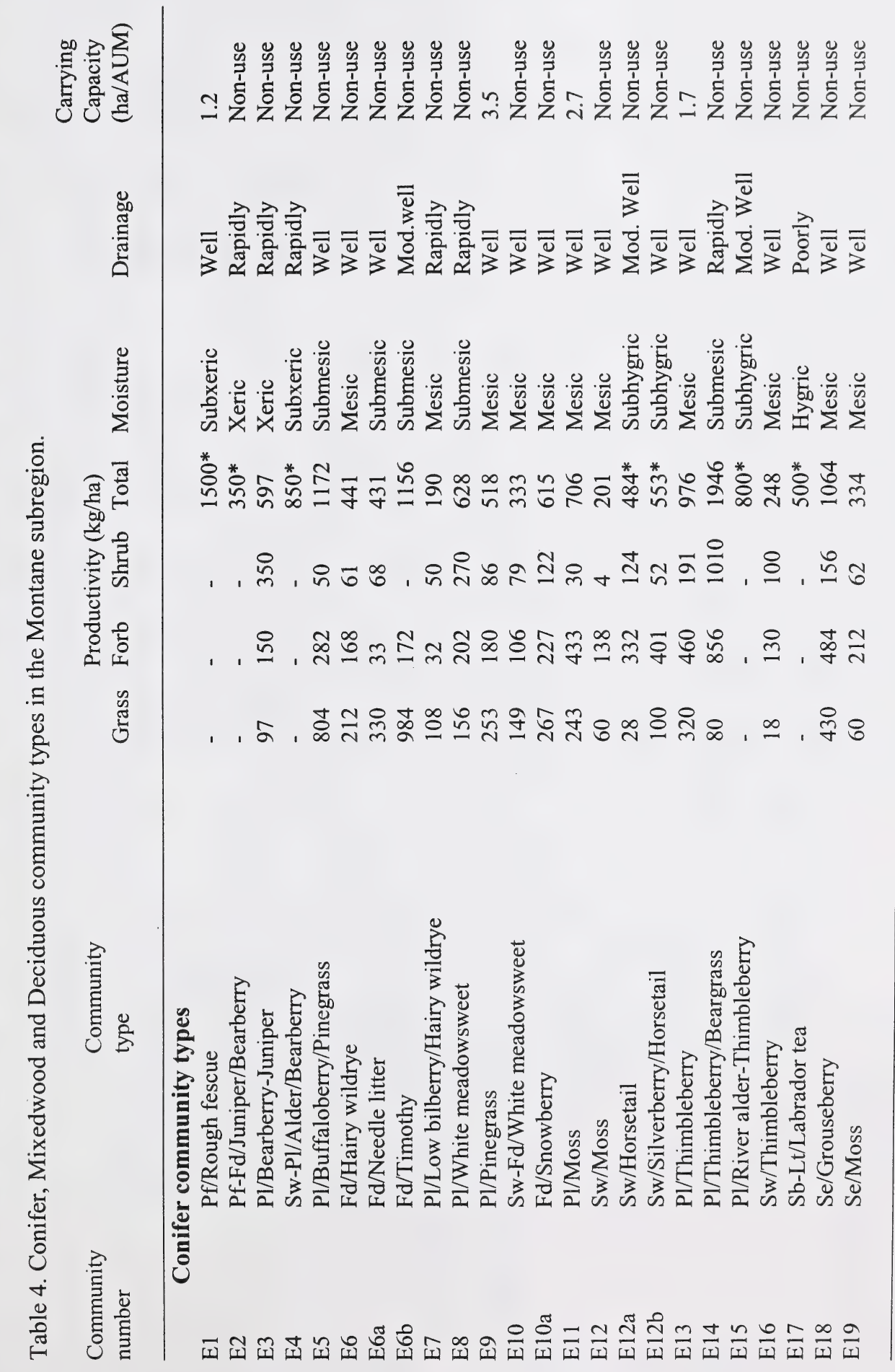

m 
嵌

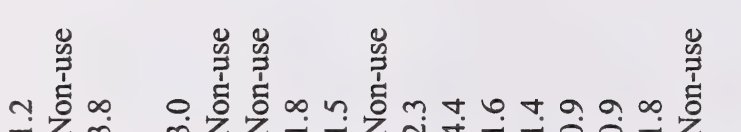

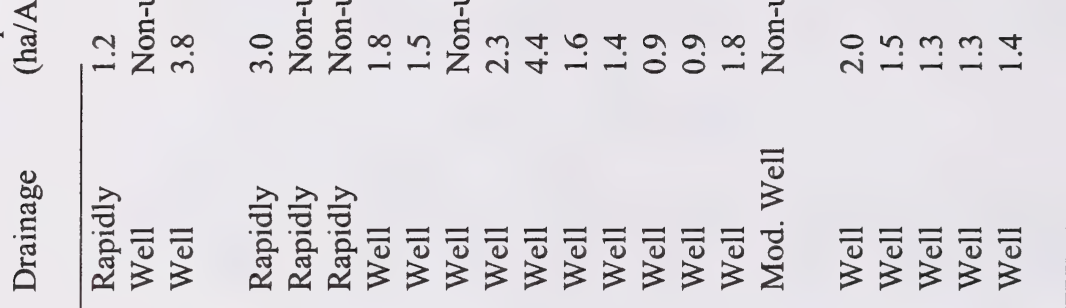

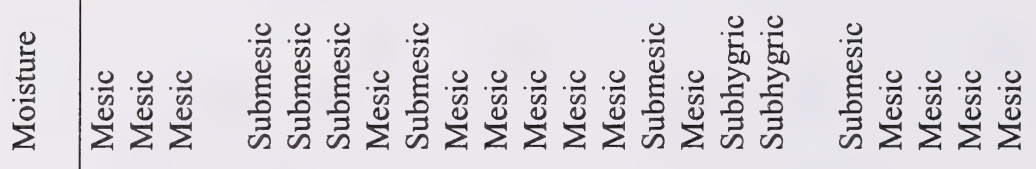

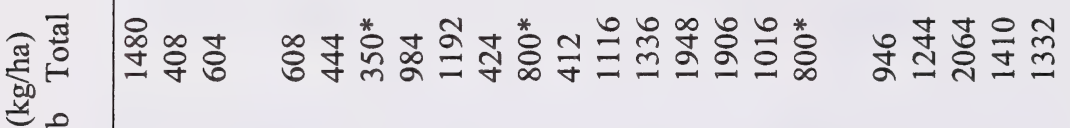

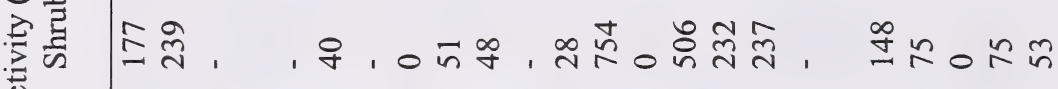
o

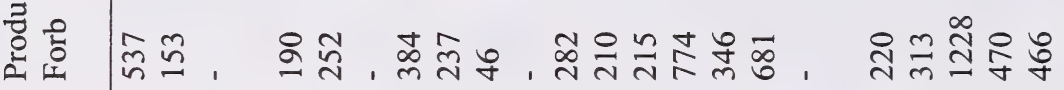

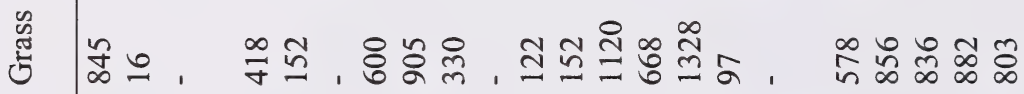

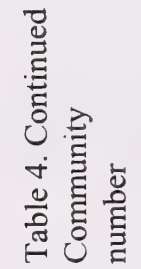

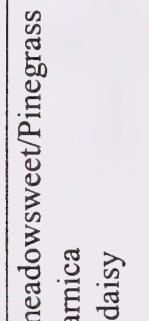

$\frac{\overbrace{}^{2}}{3}$

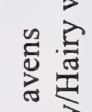

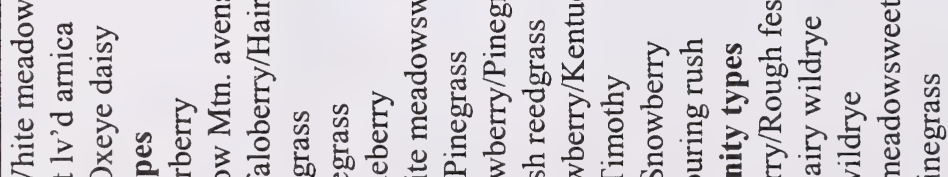

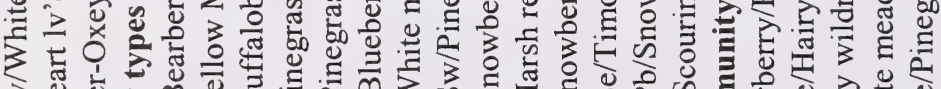

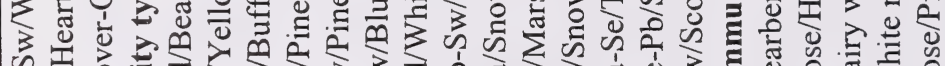
की

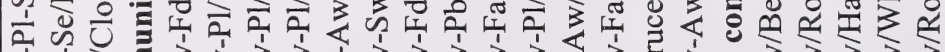

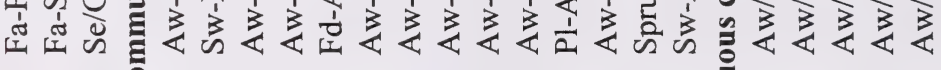




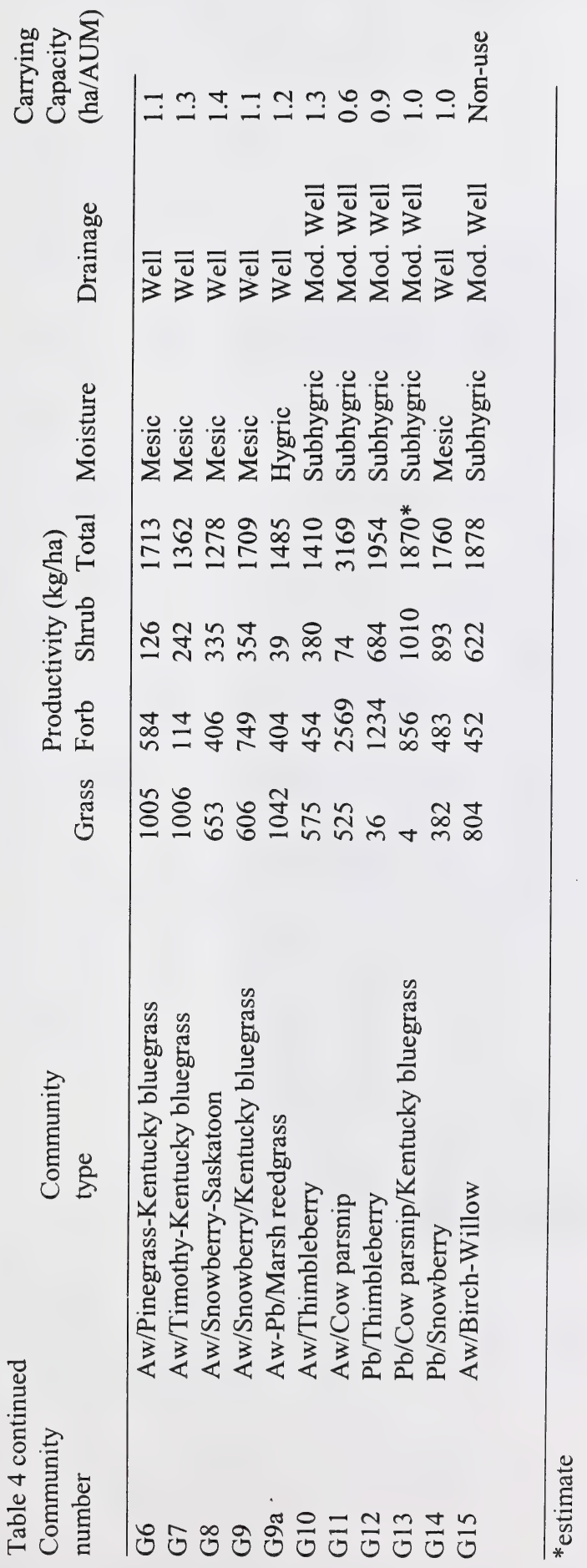




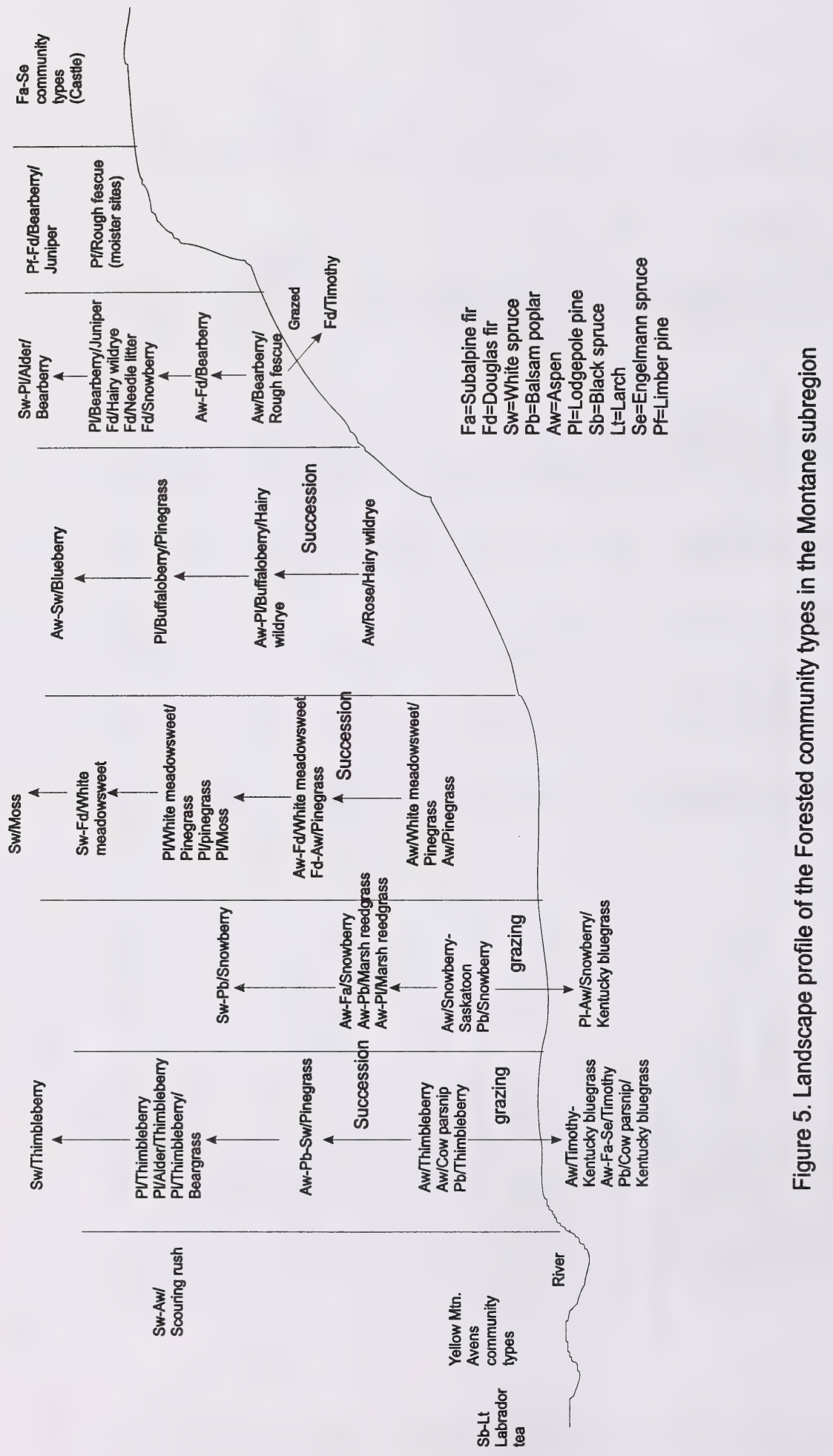

$\pm$ 


\section{CONIFEROUS COMMUNITY TYPES}

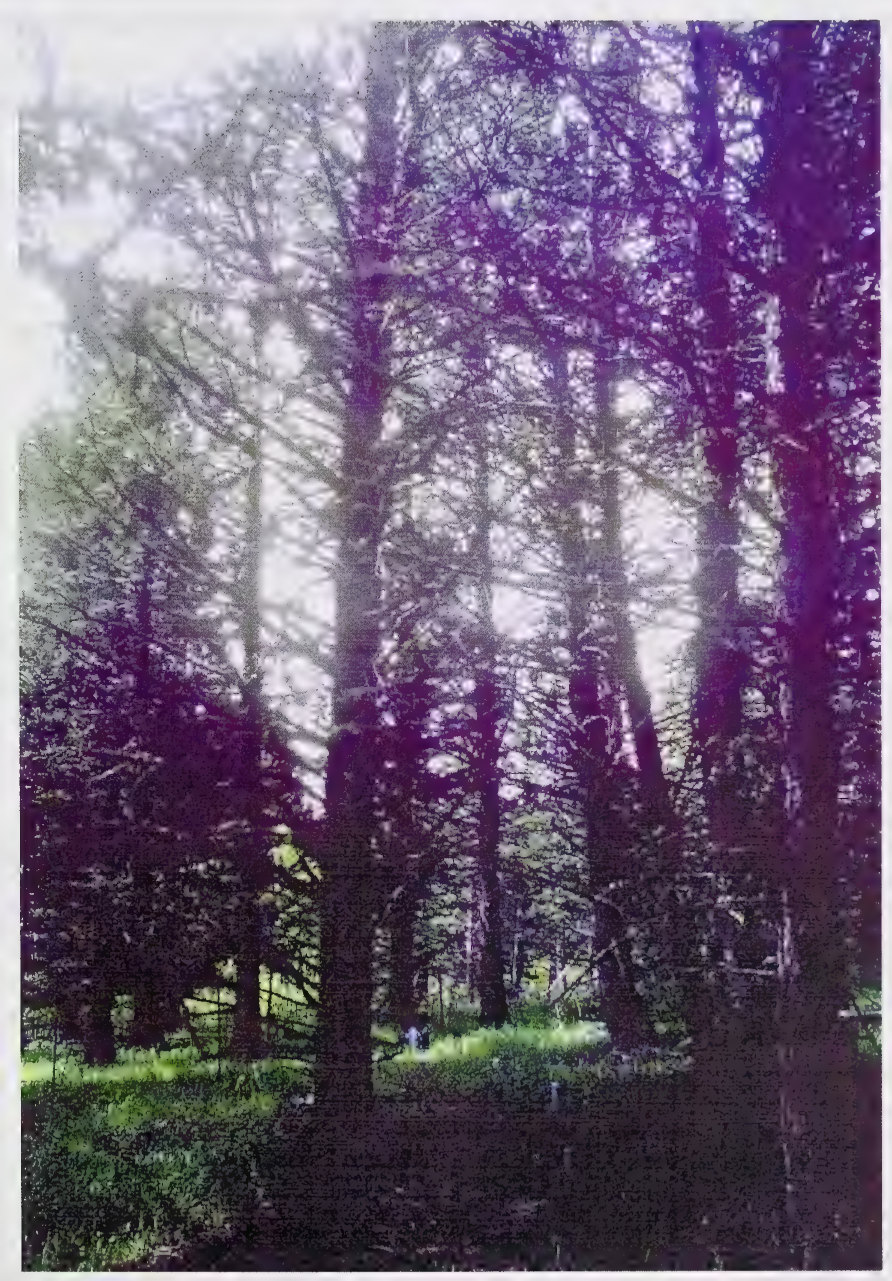

Photo 8: Conifer: This is a Douglas-fir-White spruce community type. Where the canopy opens up, grasses are fairly abundant and provide good forage for wildlife and livestock. In the absence of disturbance, this site will likely succeed to white spruce. 
Montane Coniferous key

1. Wet, poorly drained, lowland boggy sites dominated by Black spruce and Larch. or riparian areas dominated by horsetail.

Drier upland sites dominted by spruce, Douglas fir or Pine species.

Lowland boggy areas dominated by $\mathrm{Sb}$ and $\mathrm{Lt}$

Riparian areas (adjacent to streams and rivers) dominated by horsetail

1b Moist area understory dominated by horsetail.

Old river bar dominated by silverberry and horsetail

Site is well drained and drier, Black spruce and larch not present

Sb-Lt/Labrador tea $\quad 217$

$1 \mathrm{~b}$

Sw/Horsetail e12a Sw/Silverberry/Horsetail e12b

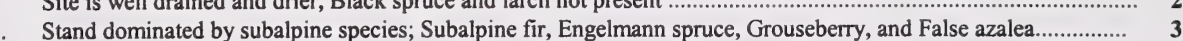

Stand not dominated by subalpine species but rather White spruce, Douglas fir, Aspen, Lodgepole pine, Limber pine, or Balsam poplar trees

3. Stand dominated by Engelmann spruce.

Stand dominated by Subalpine fir

4. Site is grazed, contains species indicative of grazing; Clover, Ox-eye daisy

Site is ungrazed.

5. Grouseberry dominates the understory

Moss dominates the understory.

...Se/Moss

6. Understory dominated by white meadowsweet...................................Fa-PI-Sw/White meadowsweet/Pinegrass Arnica dominates the understory.................................................................................Se/Heart-leaved arnica

7. Drier upper slope position dominated by Limber pine, Douglas fir, Bearberry, or Juniper.

Mesic sites, understory dominated by White meadowsweet, Pinegrass, Thimbleberry, Cow parsnip, and Moss. The overstory is dominated

by Douglas fir, Lodgepole pine and White spruce.

16

Lodgepole pine or Douglas fir dominate the community.

9. Rough fescue dominates the understory

Bearberry dominates the understory.

Se/Clover-Oxeye daisy

4

$\underline{\mathrm{e} 22}$

$\underline{\mathrm{e} 18}$

$\underline{\mathrm{e} 19}$

$\frac{\mathrm{e} 20}{\mathrm{e} 21}$

8

. Lodgepole pine dominates the community

Douglas fir dominates the community.....

11. Bearberry and Juniper dominate the understory. South slope and coarse textured soils lead to dry site conditions.

PI/Bearberry-Juniper

Low bilberry, Hairy wildrye, Alder and/or Bearberry dominate the understory

...Pf/Rough fescue

Pf-Fd/Juniper/Bearberry

el

$\frac{\mathrm{e} 2}{11}$

13

$\underline{\mathrm{e} 3}$

$\frac{12}{12}$

12 Low bilberry and Hairy wildrye dominated the understorey. Site is typically pine dominated stand adjacent to grasslands in the Ya Ha

Tinda area

PI/Low bilberry/Hairy wildrye e7

Alder and Bearberry dominate the understory and the site is a rapidly draining level area with poor nutrient regime.....

13. Site is grazed and is invaded by Timothy Sw-PI/Alder/Bearberry

Site is ungrazed and not invaded.

14. Site has small individual Snowberry plants spread evenly thoughout the community. Fd/Timothy

$\frac{\mathrm{e} 4}{\mathrm{e} 6 \mathrm{~b}}$

$\frac{\mathrm{e} 6 \mathrm{~b}}{14}$

Site has very little or no understory forage.

Fd/Snowberry

$\frac{\mathrm{e} 10 \mathrm{a}}{15}$

15

15. Site is a mature Douglas fir forest with a closed canopy and little or no understory vegetation....Fd/needle litter e6a

Site occurs on steep and dry areas or valley bottems with coarse textured outwash areas. There is a high cover of Douglas fir and a sparse understory.

16. Moist seepage areas with Cow parsnip and Thimbleberry. Fd/Hairy wildrye

$\underline{\mathrm{e} 6}$

Drier sites with White meadowsweet, Pinegrass, Buffaloberry or Moss...

17. Sw dominated sites.

Sw/Thimbleberry

$\mathrm{Pl}$ dominated sites

18. River alder and Thimbleberry dominated

Thimbleberry and Beargrass dominated, or Thimbleberry dominated.

$\mathrm{PI} /$ River alder/Thimbleberry

Thimbleberry and Beargrass dominated

PI/Thimbleberry/Beargrass

PI/Thimbleberry

Thimbleberry dominate

PI/Buffaloberry/Pinegrass

$\mathrm{Sw}, \mathrm{Pl}$ dominate the overstory

21. Moss is a major component of the understory

Pinegrass is present in the understory.

22. White spruce is the major overstory species

Lodgepole pine is the major overstory species

23. Sw, white meadowsweet, and pinegrass minimal

$\mathrm{Pl}$ dominated, white meadowsweet, Pinegrass co-dominant.

Sw/Moss

Sw-Fd/White meadowsweet PI/White meadowsweet, PI/Pinegrass

$\frac{\mathrm{e} 16}{18}$

18

el5

19

$\underline{\mathrm{e} 14}$

el3

es

21

22

23

$\underline{\mathrm{ell}}$

el2

e10

e8, e9 


\section{E1: Pf/Rough fescue \\ (Pinus flexilis/Festuca scabrella)}

$\mathbf{n}=1$ This community type was described on a steep, west-facing slope with a subxeric moisture regime. The high cover of rough fescue distinguishes this community from other, more typical limber pine dominated community types. This community probably has deeper soils and is likely protected to some extent from the dry, dessicating winds that are normally associated with limber pine community types (Corns and Achuff 1982). These conditions would favour the growth of rough fescue.

\section{PLANT COMPOSITION CANOPY COVER (\%) MEAN RANGe CONST.}

TREES

LIMBER PINE

(Pinus flexilis)

DOUGLAS-FIR

(Pseudotsuga menziesii)

$\begin{array}{lll}20 & - & 100 \\ 2 & - & 100\end{array}$

\section{SHRUBS}

SHRUBBY CINQUEFOIL

$\begin{array}{llll}\text { (Potentilla fruticosa) } & 5 & - & 100\end{array}$

\section{FORBS}

CREEPING JUNIPER

(Juniperus horizontalis)

BRISTLY BLACK CURRANT

(Ribes lacustre)

1

GOLDEN BEAN

(Thermopsis rhombifolia) 4

COMMON YARROW

(Achillea millefolium)

PASTURE SAGEWORT

(Artemisia frigida)

WILD BERGAMOT

(Monarda fistulosa)

$2-100$

1

$-\quad 100$

GRASSES

ROUGH FESCUE

(Festuca scabrella) $\quad 95 \quad-\quad 100$

SLENDER WHEAT GRASS

(Agropyron trachycaulum) $1 \quad$ - $\quad 100$

PARRY OAT GRASS

$\begin{array}{lll}\text { (Danthonia parryi) } & 1 & -\end{array}$

\section{ENVIRONMENTAL VARIABLES}

MOISTURE REGIME: SUBXERIC

NutRIENT REGIME: MESOTROPHIC

ELEVATION: $1475 \mathrm{M}$

SOIL DRAINAGE: WELL

SLOPE: $40 \%$

ASPECT: WEST

Forage Production (KG/Ha)

TOTAL $1500 \mathrm{KG} / \mathrm{HA}^{*}$

(*EsTIMATED)

SUGGESTED GRAZING CAPACITY

$1.2 \mathrm{HA} / \mathrm{AUM}$

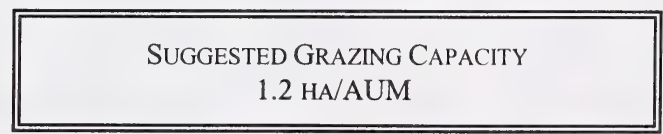




\section{E2: Pf-Fd/Juniper/Bearberry \\ (Pinus flexilis-Pseudotsuga menziesii/Juniperus communis/Arctostaphylos uva-ursi)}

$\mathbf{n}=6$ This community type occurs on steep, exposed ridge tops and upper slope positions within the montane subregion. It is characterized by dry site conditions and exposure to westerly winds. Soils are often shallow to bedrock (Archibald et al 1996), This community often forms an edaphic climax on these sites. Limber pine is normally associated with high elevations or timberline where it attains a Krummholz form (Kuchar 1973). However, the montane regions of Southwestern Alberta are found at the northern limits of the range for limber pine, thus they can generally be found at the lower elevations between prairie and coniferous forest. Limber pine, bearberry, juniper and the other associated species of this community type are all well adapted to the low moisture levels, high light intensity, heat and low soil nutrient levels which occur on these erosional, south-facing scarps (Kuchar 1973). Utilization of this site by livestock is often difficult because of the steep slope. These sites are generally considered non-use.

\section{Plant COMposition Canopy Cover (\%) MEAN RANGe CONST.}

TREES

DOUGLAS-FIR

(Pseudotsuga menziesii) $4 \quad 0-15 \quad 83$

LIMBER PINE

(Pinus flexilis)

LODGEPOLE PINE

(Pinus contorta)

$18 \quad 10-30 \quad 100$

$2 \quad 0-10 \quad 17$

SHRUBS

GROUND JUNIPER

(Juniperus horizontalis) $3 \quad 0-15 \quad 50$

COMMON JUNIPER

(Juniperus communis) $\quad 5 \quad 0-15 \quad 67$

SASKATOON

(Amelanchier alnifolia)

$4 \quad 0-10 \quad 83$

FORBS

CUT LV'D ANEMONE

(Anemone multifida)

WILD STRAWBERRY

(Fragaria virginiana)

BEARBERRY

(Arctostaphylos uva-ursi) 11

NODDING ONION

(Allium cernuum)

$1 \quad 0-1 \quad 83$

\section{GRASSES}

HAIRY WILD RYE

(Elymus innovatus)

ROUGH FESCUE

(Festuca scabrella)

4

$0-15$

83

$0-5 \quad 50$

$0-63 \quad 17$

PINEGRASS

(Calamagrostis rubescens) 3

\section{ENVIRONMENTAL VARIABLES}

MOISTURE REGIME: XERIC-SUBXERIC

NUTRIENT REGIME: SUBMESOTROPHIC TO MESOTROPHIC

\section{ELEVATION:}

1519(980-1845) M

SLOPE: $14(2-30) \%$

ASPECT: SOUTHWESTERLY

SOIL DRAINAGE: RAPIDLY

Forage ProduCtion (KG/HA)

TOTAL 350*

(*Estimated)

SugGeSted GRAZING CAPACITY

NON-USE

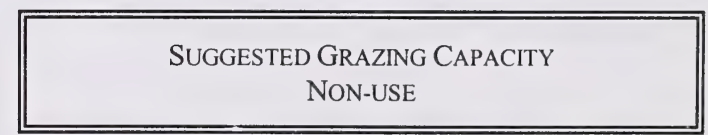




\section{E3: P1/Bearberry-Juniper \\ (Pinus contorta/Arctostaphylos uva-ursi-Juniperus spp.)}

$\mathbf{n}=\mathbf{5}$ This community type is similar to the Limber pine-Douglas-fir/Juniper/Bearberry community type previously described, but occurs on slightly richer and better developed soils. Dry site conditions from south exposures or coarsetextured soils are characteristic of this community type (Archibald et al. 1996). The dry site conditions limit the amount of forage this site can produce and the steep slope limits access to livestock. As a result, this community type would be considered non-use.

\section{PLANT COMPOSITION CANOPY COVER (\%) MEAN RANGE CONST.}

\section{TREES}

LIMBER PINE

(Pinus flexilis)

DOUGLAS-FIR

(Pseudotsuga menziesii)
LODGEPOLE PINE

(Pinus contorta)

$44 \quad 3-70 \quad 100$

SHRUBS

COMMON BEARBERRY

(Arctostaphylos uva-ursi) 3

JUNIPER

(Juniperus spp.)

SASKATOON

(Amelanchier alnifolia)

SHRUBBY CINQUEFOIL

(Potentilla fruticosa)

CANADA BUfFaloberRy

(Shepherdia canadensis)

$1 \quad 0-5 \quad 17$

$1 \quad 0-10 \quad 25$

$\begin{array}{ll}0-30 & 25 \\ 0-31 & 75 \\ 0-2 & 33 \\ 0-2 & 16 \\ 0-16 & 50\end{array}$

$6 \quad 0-31 \quad 75$

1

1

2

$0-16$

50

\section{FORBS}

NODDING ONION

(Allium cernuum)

CUT-LEAVED ANEMONE

(Anemone multifida)

NORTHERN BEDSTRAW

(Galium boreale)

YELLOW HEDYSARUM

(Hedysarum sulphurescens) 1

GRASSES

HAIRY WILD RYE

(Elymus innovatus)

SEDGE

(Carex spp.)

PINEGRASS

(Calamagrostis rubescens) 15

\section{ENVIRONMENTAL VARIABLES}

MOISTURE REGIME:

XERIC TO MESIC

NUTRIENT REGIME:

MESOTROPHIC

ELEVATION RANGE:

$1700(1460-2010) \mathrm{M}$

ASPECT: SOUTH TO WEST

SLOPE:

$52(14-80) \%$ (steep slopes and hill crests)

SOIL DRAINAGE: RAPIDLY

FORAGE PRODUCTION (KG/HA)

GRASS 97(0-292)

FORB 150(0-276)

SHRUB 350(160-722)

TOTAL 597(160-998)

SUGGESTED GRAZING CAPACITY

NON-USE

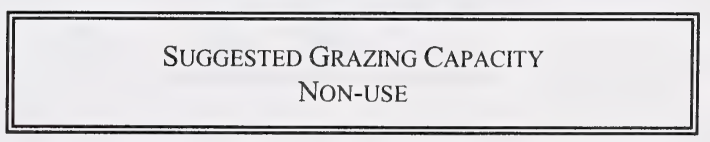




\section{E4: Sw-Pl/Alder/Bearberry \\ (Picea glauca-Pinus contorta/Alnus crispa/Arctostaphylos uva-ursi)}

$\mathbf{n}=1 \quad$ This community was described by Corns and Achuff (1982) in the Banff and Jasper Mountain ecodistricts. It occupies rapidly drained, level areas with a poor nutrient regime. This community is similar to Archibald et al's. (1996) bearberry Aw-Sw-Pl ecosite phase. Succession will generally be to white spruce, but succession rates will be slow because of the dry site conditions. The presence of green alder indicates there is a higher moisture content at some point in the growing season, making this community type slightly moister than the modal bearberry ecosite. The high tree cover and poor nutrient status would limit the amount of forage for domestic livestock. This community would be rated non-use.

Plant Composition CANopy Cover (\%) MEAN RANGe CONST.

\section{TREES}

LODGEPOLE PINE

(Pinus contorta)

WHITE SPRUCE

(Picea glauca)

ASPEN

(Populus tremuloides)

$\begin{array}{lll}10 & - & 100 \\ 32 & - & 100 \\ 12 & - & 100\end{array}$

\section{SHRUBS}

GROUND JUNIPER

(Juniperus communis)

GREEN ALDER

(Alnus crispa)

SASKATOON

(Amelanchier alnifolia) 32

BUFFALOBERRY

(Shepherdia canadensis) 30

TALL BILBERRY

(Vaccinium caespitosum) 22

12

82

FORBS

BEARBERRY

(Arctostaphylos uva-ursi) 12

TWIN FLOWER

(Linnaea borealis)

2

GRASSES

MARSH REEDGRASS

(Calamagrostis canadensis) 30

Тімотну

(Phleum pratense)

20
100

100

100

100

\section{ENVIRONMENTAL VARIABLES}

MOISTURE REGIME: SUBXERIC

NUTRIENT REGIME: MESOTROPHIC

ELEVATION RANGE : $1360 \mathrm{M}$

SOIL DRAINAGE: RAPIDLY

\section{Forage Production (KG/HA)}

TOTAL 850*

(*ESTIMATED)

100

100

100

SUGGESTED GRAZING CAPACITY NON-USE 


\section{E5: Pl/Buffaloberry/Pinegrass \\ (Pinus contorta/Shepherdia canadensis/Calamagrostis rubescens)}

$\mathbf{n}=4$ This community type occurs on submesic, well drained, south and west-facing slopes. It is situated in slightly lower slope positions and therefore has better developed soils than the Limber pine and bearberry-dominated community types previously described. Archibald et al. (1996) described this community type as being part of the Canada buffaloberry-hairy wildrye ecosite. They felt this ecosite to be relatively dry for the subregion, but not as dry as the limber pine and bearberry ecosites. This community type has only sparse understory vegetation and therefore has only limited forage for domestic livestock. It should be rated as non-use.

\section{Plant COMPOSITION CANOPY COVER (\%) MEAN RANGE CONST.}

TREES

LODGEPOLE PINE

(Pinus contorta)

$52 \quad 35-71 \quad 100$

ASPEN

(Populus tremuloides)

$1 \quad 0-5 \quad 25$

\section{SHRUBS}

CANADA BUFFALOBERRY

(Shepherdia canadensis) $19 \quad 3-35 \quad 100$

SHINING WILLOW

(Salix lucida)

PRICKLY ROSE

(Rosa acicularis)

$3 \quad 0-11 \quad 25$

$1 \quad 0-2 \quad 25$

FORBS

STRAWBERRY

(Fragaria virginiana)

SHOWY ASTER

(Aster conspicuus)

HEART-LEAVED ARNICA

(Arnica cordifolia)

FIREWEED

(Epilobium angustifolium)2

$$
4
$$

11

5

5

$0-15 \quad 75$

0-6 $\quad 100$

\section{GRASSES}

PINEGRASS

(Calamagrostis rubescens) 15

HAIRY WILD RYE

(Elymus innovatus)

$23 \quad 0-40 \quad 75$

\section{ENVIRONMENTAL VARIABLES}

MOISTURE REGIME:

SUBXERIC TO MESIC

NUTRIENT REGIME: SUBMESOTROPHIC

ELEVATION:

$$
\text { 1544(1502-1580)M }
$$

ASPECT: SOUTHERLY

SLOPE: $17(5-30) \%$

SOIL DRAINAGE: RAPIDLY TO MODERATELY

Forage Production (KG/HA)

$\begin{array}{ll}\text { GRASS } & 840 \\ \text { FORB } & 282 \\ \text { SHRUB } & 50 \\ \text { TOTAL } & 1172\end{array}$

\section{SUGGESTED GRAZING CAPACITY}

NON-USE 


\section{E6: Fd/Hairy wildrye \\ (Pseudotsuga menziesii/Elymus innovatus)}

$\mathbf{n}=11$ This community type occurs on steep, dry sites throughout the subregion. Douglas fir is usually restricted to steep, south facing slopes, shallow rocky soils and coarse-textured outwash in valley bottoms (Strong 1992). The soils of this type are not as rich as the previously described P1/Buffaloberry, but are better than the bearberry and limber pine dominated ecosites. This community has a high cover of Douglas fir and a very sparse understory. Consquently, there is little forage available for domestic livestock. As a result, this community type would be rated as non-use.

\section{PLANT COMPOSITION CANOPY COVER (\%)}

MEAN RANGe CONST.

TREES

LODGEPOLE PINE

(Pinus contorta)

DOUGLAS FIR

(Pseudotsuga menziesii) $53 \quad 20-80 \quad 100$

\section{SHRUBS}

PRICKLY ROSE

(Rosa acicularis)

WHITE MEADOWSWEET

(Spiraea betulifolia) $\quad 5 \quad 0-19 \quad 73$

COMMON JUNIPER

(Juniperus communis) $\quad 1 \quad 0-15 \quad 9$

\section{FORBS}

SHOWY ASTER
(Aster conspicuus)

VEINY MEADOW RUE

$\begin{array}{llll}\text { (Thalictrum venulosum) } & 1 & 0-4 & 18\end{array}$

STRAWBERRY

(Fragaria virginiana)

HEART-LEAVED ARNICA

(Arnica cordifolia)

CREAM-COLORED VETCHLING

(Lathyrus ochroleucus)

$4 \quad 0-15 \quad 82$

$0-8 \quad 91$

$0-23 \quad 46$

$0-2 \quad 64$

\section{GRASSES}

HAIRY WILDRYE

$\begin{array}{llll}\text { (Elymus innovatus) } & 7 & 0-15 & 91\end{array}$

PINEGRASS

(Calamagrostis rubescens) $3 \quad 0-13 \quad 73$

\section{ENVIRONMENTAL VARIABLES}

MOISTURE REGIME: SUBXERIC-MESIC

NUTRIENT REGIME: MESOTROPHIC

ELEVATION: $1565(1432-1765) \mathrm{M}$

ASPECT: VARIABLE

SLOPE: $13(3-45) \%$

SOIL DRAINAGE:

WELL TO RAPIDLY

Forage Production (KG/HA)

GRASS 212(0-498)

FORB 168(12-398)

SHRUB 61(0-564)

TOTAL 441(58-896)

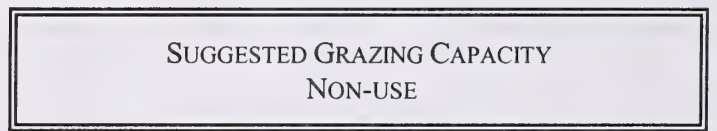




\section{E6a: Fd/Needle litter \\ (Pseudotsuga menziesii)}

$\mathbf{n}=1$ This community type represents a mature Douglas fir forest. The closed canopy of Douglas fir limits the light reaching the forest floor restricting the growth of the understory vegetation. Consequently there is little forage available for domestic livestock and this community type would be rated as non-use.

PLANT COMPOSITION CANOPY COVER (\%) MEAN RANGe CONST.

TREES

DOUGLAS FIR

(Pseudotsuga menziesii) $35 \quad-\quad 100$

\section{SHRUBS}

PRICKLY ROSE

(Rosa acicularis)

SHRUBBY CINQUEFOIL

(Potentilla fruticosa)

$\begin{array}{lll}2 & - & 100 \\ 1 & - & 100\end{array}$

\section{FORBS}

LOW GOLDENROD

(Solodago missourensis)

SILKY PERENNIAL LUPINE

(Lupinus sericeus)

STRAWBERRY

(Fragaria virginiana) 2

STICKY PURPLE GERANIUM

(Geranium viscosissimum) 1

THREE FLOWERED AVENS

(Geum triflorum)

AMERICAN VETCH

(Vicia americana)

\section{GRASSES}

RICHARDSON'S NEEDLEGRASS

(Stipa richardsonii) 8

KENTUCKY BLUEGRASS

(Poa pratensis)

PARRY'S OATGRASS

(Danthonia parryi)

ROUGH FESCUE

(Festuca scabrella)

IDAHO FESCUE

(Festuca idahoensis)
100

100

100

100

100

\section{ENVIRONMENTAL VARIABLES}

MOISTURE REGIME: SUBXERIC-SUBMESIC

NUTRIENT REGIME: MESOTROPHIC

ELEVATION: 1570(1493-1649) M

ASPECT:

SOUTH

SLOPE:

$$
20 \%
$$

SOIL DRAINAGE:

WELL

\section{Forage Production (KG/HA)}

$\begin{array}{ll}\text { GRASS } & 330(0-660) \\ \text { FORB } & 33(0-66) \\ \text { SHRUB } & 68(22-114) \\ \text { TOTAL } & 431(114-748)\end{array}$

SUGGESTED GRAZING CAPACITY NON-USE 


\section{E6b: Fd/Timothy \\ (Pseudotsuga menziesii/Phleum pratense)}

$\mathbf{n}=1$ This community type was described on a hill crest and represents a Douglas fir/Rough fescue dominated community type that has been extensively utilized by livestock. Livestock often congregate in these open Douglas fir stands on the hilltops. These sites are often windy, cool and the livestock can escape from the bugs. The heavy use on these sites favours the growth of timothy over the native grass species. These sites are quite productive and should be rated as secondary range.

\section{PLANT COMPOSITION CANOPY COVER (\%) MEAN RANGe CONST.}

TREES

ASPEN

(Populus tremuloides) 1

DOUGLAS FIR

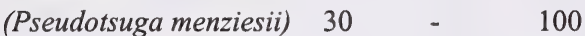

FORBS

SPARROW'S EGG LADY'S SLIPPER

(Cypripedium paserinum) 3

VEINY MEADOW RUE

(Thalictrum venulosum) $2 \quad-\quad 100$

CANADA THISTLE

(Cirsium arvense)

NORTHERN BEDSTRAW

(Galium boreal)

LOW GOLDENROD

(Solodago missourensis)

GraSSES

TIMOTHY

(Phleum pratense)

$24 \quad-\quad 100$

BLUE JOINT

(Calamagrostis canadensis)2 $\quad$ - $\quad 100$

JUNE GRASS

(Koeleria macrantha) $\quad 5 \quad$ - $\quad 100$

BLUE BUNCH WHEATGRASS

$\begin{array}{llll}\text { (Agropyron spicatum) } & 5 & - & 100\end{array}$

HAIRY WILD RYE

$\begin{array}{llll}\text { (Elymus innovatus) } & 2 & - & 100\end{array}$

AWNLESS BROME

(Bromus inermis)

\section{ENVIRONMENTAL VARIABLES}

MOISTURE REGIME: SUBXERIC

NUTRIENT REGIME: MESOTROPHIC

ELEVATION: $1619 \mathrm{M}$

ASPECT: SOUTH

SLOPE: $2 \%$

SOIL DRAINAGE:

MODERATELY WELL

\section{Forage Production (KG/HA)}

$\begin{array}{ll}\text { GRASS } & 984 \\ \text { FORB } & 172 \\ \text { TOTAL } & 1156\end{array}$

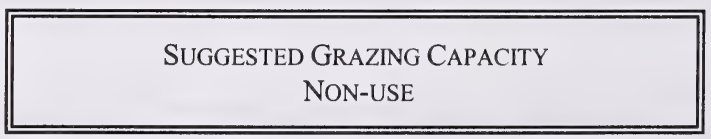




\section{E7: PI/Low bilberry/Hairy wildrye \\ (Pinus contorta/Vaccinium cespitosum/Elymus innovatus)}

$\mathbf{n}=\mathbf{1}$ This community is typical of the pine dominated community types adjacent to the grasslands within the Ya $\mathrm{Ha}$ Tinda area. They tend to be dry sites, that are well drained with poor to medium nutrient regimes. Forage production on these sites tends to be low because of the closed canopy cover. Succession in the absence of disturbance will be to white spruce.

Plant COMPOSITION CANOPY COVER (\%) MEAN RANGe Const.

TREES

LODGEPOLE PINE

(Pinus contorta)

WHITE SPRUCE

(Picea glauca)

37

100

\section{SHRUBS}

(Vaccinium cespitosum) 13

SHRUBBY CINQUEFOIL

(Potentilla fruticosa)

100

100
LOW BILBERRY

\section{ENVIRONMENTAL VARIABLES}

MOISTURE REGIME:

SUBMESIC-MESIC

NUTRIENT REGIME: MESOTROPHIC

ELEVATION:

$1600 \mathrm{M}$

ASPECT:

VARIABLE

SOIL DRAINAGE:

RAPIDLY

100

(Fragaria virginiana) 1

SMALL LEAVED EVERLASTING

(Antennaria parviflora) 1

CUT LEAVED ANEMONE

(Anemone multifida)

1

100

ALPINE HEDYSARUM

100

(Hedysarum alpinum)

100

\section{GRASSES}

HAIRY WILDRYE

$\begin{array}{llll}\text { (Elymus innovatus) } & 4 & - & 100\end{array}$

ROUGH FESCUE

(Festuca scabrella)

3

100

LICHEN

$2 \quad-\quad 100$

\section{SugGeSTED GRAZING CAPACITY} NON-USE

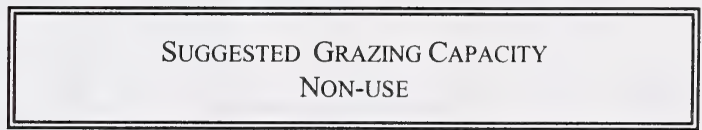




\section{E8: PI/White meadowsweet \\ (Pinus contorta/Spiraea betulifolia)}

$\mathbf{n}=6$ This community is one of several community types which represent the mesic/medium ecosite for the Montane subregion. These sites can be dominated by Douglas fir, white spruce, aspen or lodgepole pine. The understory can be dominated by white meadowsweet, pinegrass or feather moss depending on the successional status of the stand. In the vicinity of the Crowsnest Pass creeping mahonia is also common on these sites (Archibald et al. 1996). White meadowsweet is well adapted to growing on dry rocky slopes (MacKinnon et al. 1992). The presence of a high cover of white meadowsweet may indicate slightly drier conditions and shallower soils than a community dominated by pinegrass. This community type produces little forage for domestic livestock and should be considered non-use.

\section{Plant COMPOSITION CANOPY COVER (\%)} MEAN RANGE CONST.

\section{TREES}

\section{LODGEPOLE PINE}

(Pinus contorta)

ENGELMANN SPRUCE

(Picea engelmannii)

$$
54
$$$$
34-80
$$$$
100
$$$$
4 \quad 0-23
$$

\section{SHRUBS}

\section{CANADA BUFFALOBERRY}

(Shepherdia canadensis)

GROUND JUNIPER

\section{(Juniperus communis)}

WHITE MEADOWSWEET

(Spiraea betulifolia)

THIMBLEBERRY

(Rubus parviflora)

18

$18 \quad 7-26 \quad 100$

$8 \quad 0-35 \quad 67$

\section{FORBS}

WILD STRAWBERRY

$0-5 \quad 33$

$0-4 \quad 17$
(Fragaria virginiana)

HEART-LEAVED ARNICA

(Arnica cordifolia)

SHOWY ASTER

(Aster conspicuus)

TALL BILBERRY

(Vaccinium membranaceum)

$4 \quad 0-13 \quad 83$

$4 \quad 1-8 \quad 100$

$3 \quad 0-11 \quad 33$

$0-35 \quad 33$

\section{GRASSES}

HAIRY WILD RYE

(Elymus innovatus)

T $\quad 0-2$

PINEGRASS

(Calamagrostis rubescens) 10

$0-35$

$0-15$

Moss SPP.

$3 \quad 0-15 \quad 33$

\section{ENVIRONMENTAL VARIABLES}

MoISTURE REGIME: SUBMESIC TO MESIC

NUTRIENT REGIME: MESOTROPHIC

ELEVATION RANGE:

1602(1460-1768) M

ASPECT:

SOUTH TO SOUTHWEST

SLOPE: $24(2-53) \%$

SOIL DRAINAGE: WELL TO RAPIDLY

Forage Production (KG/HA)

\section{SUGGESTED GRAZING CAPACITY} NON-USE 


\section{E9: Pl/Pinegrass \\ (Pinus contorta/Calamagrostis rubescens)}

$\mathbf{n = 1 5}$ This community is dominated by a lodgepole pine overstory and an understory of pinegrass. Succession will be to white spruce or Douglas fir, but the extensive fire and disturbance history in the Montane has resulted in a predominance of lodgepole pine and Douglas fir (Archibald et al. 1996). This community is also very similar to the previously described P1/White meadowsweet community type, but the high cover of pinegrass and low cover of white meadowsweet may indicate slightly moister, better developed soils. Pinegrass is generally unpalatable to livestock, but if it is grazed early in the spring they will utilize it as a forage source. The forage productivity of this community type is quite low. As a result, this community should be rated as secondary or non-use.

\section{Plant COMPOSITION CANOPY COVER (\%)}

TREES

LODGEPOLE PINE

(Pinus contorta)

WHITE SPRUCE

(Picea glauca)

SHRUBS

Rose

(Rosa acicularis)

WHITE MEADOWSWEET

(Spiraea betulifolia)

CANADA BUFFALOBERRY

(Shepherdia canadensis)

SNOWBERRY

(Symphoricarpos occidentalis) 1

$\begin{array}{lll}52 & 35-70 & 100 \\ 6 & 0-30 & 62\end{array}$

\section{FORBS}

SHOWY ASTER

(Aster conspicuus)

HEART-LEAVED ARNICA

(Arnica cordifolia)

TWINFLOWER

(Linnaea borealis) $\quad 16 \quad 0-50 \quad 80$

STRAWBERRY

(Fragaria virginiana)

\section{GRASSES}

HAIRY WILDRYE

(Elymus innovatus)

PINEGRASS

(Calamagrostis rubescens) 14

KEELED BROME

(Bromus carinatus)

$4 \quad 0-28 \quad 20$

\section{ENVIRONMENTAL VARIABLES}

MOISTURE REGIME: MESIC

NUTRIENT REGIME:

MESOTROPHIC TO PERMESOTROPHIC

ELEVATION: 1572(1432-1710)M

SOIL DRAINAGE: WELL TO RAPIDLY

ASPECT: SOUTHERLY

SLOPE: $14(2-30) \%$

Forage Production (KG/Ha)

GRASS 253(80-584)

FORB $\quad 180(0-586)$

SHRUB 86(0-182)

TOTAL 518(266-916)

SUGGESTED GRAZING CAPACITY

$3.5 \mathrm{HA} / \mathrm{AUM}$ 


\section{E10: Sw-Fd/White meadowsweet \\ (Picea glauca-Pseudotsuga menziesii/Spiraea betulifolia)}

$\mathbf{n}=4$ This community type is successional more advanced than the P1/White meadowsweet and P1/Pinegrass community types previously described. Archibald et al. (1996) described the successional changes from pine to white spruce and douglas fir on these mesic/medium sites. As succession occurs there is less light reaching the forest floor and understory vegetation becomes very sparse. As a result, there is little forage for domestic livestock underneath these forested stands. This community type would be rated as non-use.

\section{Plant COMPOSITION CANOPY COVER (\%) Mean Range Const.}

TREES

WHITE SPRUCE

(Picea glauca)

DOUGLAS FIR

(Pseudotsuga menziesii) $\quad 30 \quad 10-40-100$

LODGEPOLE PINE

(Pinus contorta)

\section{SHRUBS}

WHITE MEADOWSWEET

$\begin{array}{llll}\begin{array}{l}\text { (Spiraea betulifolia) } \\ \text { THIMBLEBERRY }\end{array} & 3 & 0-5 & 50 \\ \begin{array}{l}\text { (Rubus parviflorus) } \\ \begin{array}{l}\text { TWIN FLOWER } \\ \text { (Linnaea borealis) }\end{array}\end{array} & 3 & 0-8 & 50 \\ & 3 & 0-9 & 50\end{array}$

FORBS

WILD STRAWBERRY

(Fragaria virginian

SHOWY ASTER

(Aster conspicuus)

FIREWEED

(Epilobium angustifolium) $1 \quad 0-1 \quad 25$

WESTERN MEADOW RUE

(Thalictrum occidentale)

FALSE SOLOMON'S SEAL

(Smilacina racemosa)

HEART-LEAVED ARNICA

(Arnica cordifolia)

$4 \quad 0-10 \quad 50$

GRASSES

HAIRY WILDRYE

(Elymus innovatus) $\quad 1 \quad 0-4 \quad 50$

PINEGRASS

(Calamagrostis rubescens) $4 \quad 0-7 \quad 100$

\section{ENVIRONMENTAL VARIABLES}

MOISTURE REGIME: SUBMESIC TO MesiC

NUTRIENT REGIME: MESOTROPHIC

ELEVATION:1556(1487-1600)M

ASPECT: VARIABLE

SLOPE: $23(14-35) \%$

SOIL DRAINAGE: WELL TO RAPIDLY

\section{Forage Production (KG/HA)}

$\begin{array}{ll}\text { GRASS } & 149(20-366) \\ \text { FORB } & 106(42-154) \\ \text { SHRUB } & 79(0-166) \\ \text { TOTAL } & 333(222-480)\end{array}$

SUGGESTED GRAZING CAPACITY NON-USE 


\section{E10a: Fd/Snowberry \\ (Pseudotsuga menziesii/Symphoricarpos occidentalis)}

$\mathbf{n}=\mathbf{5}$ This community type was described on moderate south and westerly facing slopes on the east side of the Porcupine Hills. Snowberry is generally indicative of nutrient rich seepage areas in the Montane subregion and generally forms thickets in the lower slope positions. The snowberry in this community type consists of small individual plants that are uniformly scattered throughout the community. Archibald et al. (1996) did not recognize this community type and placed it within the hairy wildrye (submesic/medium) ecosite because of the moderate slopes the community was described on. However, the high constancy of snowberry in this community type appears to indicate slightly higher moisture and nutrients. Consequently, this community type was placed within the mesic/medium ecosite. Livestock may use these community types because of the open nature of the tree canopy, but the forage production is only moderate and the areas where this community type were described are generally inaccessible to livestock. As a result this community type should be rated as non-use range.

\section{Plant Composition Canopy Cover (\%)}

TREES MEAN RANGe CONST.

DOUGLAS FIR

(Pseudotsuga menziesii) $\quad 40 \quad 25-55 \quad 100$

SHRUBS

WHITE MEADOWSWEET

(Spiraea betulifolia) $\quad 3 \quad 0-14 \quad 40$

SNOWBERRY

(Symphoricarpos occidentale) $12 \quad 7-18 \quad 100$

PRICKLY ROSE

$\begin{array}{llll}\text { (Rosa acicularis) } & 3 & 1-8 & 100\end{array}$

PIN CHERRY

$\begin{array}{llll}\text { (Prunus pensylvanica) } & 1 & 0-3 & 40\end{array}$

FORBS

WILD STRAWBERRY

(Fragaria virginiana)

SMOOTH ASTER

(Aster laevis)

BALSAMROOT

(Balsamorhiza sagittata) $2 \quad 0-8 \quad 20$

WESTERN MEADOW RUE

(Thalictrum occidentale) $1 \quad 0-4 \quad 20$

AMERICAN VETCH

(Vicia americana) $1 \quad 1-2 \quad 100$

STAR-FLOWERED SOLOMON'S-SEAL

$\begin{array}{llll}\text { (Smilacina stellata) } & 1 & 0-2 & 80\end{array}$

GRASSES

KENTUCKY BLUEGRASS

$\begin{array}{llll}\text { (Poa pratensis) } & 3 & 0-12 & 80\end{array}$

GREEN NEEDLE GRASS

(Stipa viridula)

$2-10-40$

$2 \quad 0-4 \quad 60$
SEDGE

$\begin{array}{llll}\text { (Carex spp.) } & 3 & 1-5 & 80\end{array}$

PARRY'S OATGRASS

(Danthonia parryi) $4 \quad 0-10 \quad 60$

ENVIRONMENTAL VARIABLES

MoISTURE REGIME: SubMESIC TO MESIC

NUTRIENT REGIME:

MESOTROPHIC TO PERMESOTROPHIC

ELEVATION: 1463 (1372-1524)M

ASPECT: VARIABLE

SLOPE: $16(5-35) \%$

SOIL DRAINAGE: WELL TO RAPIDLY

Forage Production (KG/HA)

GRASS 267(112-442)

FORB 227(0-408)

SHRUB $122(0-184)$

TOTAL 615(112-898)

\section{SUGGESTED GRAZING CAPACITY} NON-USE 


\section{E11: P1/Moss \\ (Pinus contorta/Moss spp.)}

$\mathbf{n}=6$ This community type is similar to the previously described P1/Pinegrass and P1/White meadowsweet communities, but represents further succession. This community was described on moister sites, which probably escaped fire and disturbance, allowing succession to occur. Continued succession in the absence of disturbance will likely be to the $\mathrm{Sw} / \mathrm{Moss}$ dominated community type. This community type is moderately productive for domestic livestock. The higher moisture conditions favour the growth of fireweed and aster spp. These species are moderately palatable to livestock. This community type would be rated as secondary range for domestic livestock.

\section{PLANT COMPOSITION CANOPY COVER(\%)} MEAN RANGe CONST.

TREES

WHITE SPRUCE

(Picea glauca)

LODGEPOLE PINE

(Pinus contorta)

\section{SHRUBS}

WILLOW

(Salix spp.)

WHITE MEADOWSWEET

(Spiraea betulifolia) T

BUFFALOBERRY

(Shepherdia canadensis)

\section{FORBS}

STRAWBERRY

(Fragaria virginiana) 2

FIREWEED

(Epilobium angustifolium) 10

LINDLEY'S ASTER

(Aster ciliolatus)

DANDELION

(Taraxacum officinale) 6

WESTERN MEADOW RUE

(Thalictrum occidentale) 3

4

42

$13-69 \quad 100$

GRASSES

SEDGE

(Carex spp.)

VIRGINIA WILDRYE

(Elymus virginicus)

Moss
$11 \quad 4-20 \quad 100$

$8 \quad 2-14 \quad 100$

$46 \quad 12-65 \quad 100$

\section{ENVIRONMENTAL VARIABLES}

MOISTURE REGIME: MESIC TO HYGRIC

NUTRIENT REGIME: MESOTROPHIC

ELEVATION: 1742 (1707-1798)M

ASPECT: NORTHERLY

SLOPE: $1 \%$

DRAINAGE: MODERATELY WELL

FORAGE PRODUCTION (KG/HA)

$\begin{array}{ll}\text { GRASS } & 243(0-570) \\ \text { FORB } & 433(0-832) \\ \text { SHRUB } & 30(0-96) \\ \text { TOTAL } & 706(136-1402)\end{array}$

SUGGESTED GRAZING CAPACITY

$2.7 \mathrm{HA} / \mathrm{AUM}$ 


\section{E12: Sw/Moss \\ (Picea glauca/Moss spp.)}

$\mathbf{n}=14$ This community type is similar to the previously described Sw-Fd/White meadowsweet community, but represents further succession. This community was described on northerly aspects, which probably escaped fire and disturbance, allowing succession to occur. Note as succession occurs there is a corresponding drop in forage productivity from $500-600 \mathrm{~kg} / \mathrm{ha}$ in the $\mathrm{Pl}$ community types to $201 \mathrm{~kg} / \mathrm{ha}$ in this community type. This community type would be rated as non-use for domestic livestock.

\section{PLANT COMPOSITION CANOPY COVER (\%)} MEAN RANGe CONST.

TREES

WHITE SPRUCE

(Picea glauca)

ASPEN

(Populus tremuloides)

$63 \quad 10-90 \quad 100$

$3 \quad 0-20 \quad 34$

\section{SHRUBS}

PRICKLY ROSE

(Rosa acicularis)

SNOWBERRY

(Symphoricarpos

occidentalis)

\section{FORBS}

HEART-LEAVED ARNICA

(Arnica cordifolia)

VEINY MEADOW RUE

(Thalictrum venulosum)

SHOWY ASTER

(Aster conspicuus)

TWINFLOWER

(Linnaea borealis)

WINTERGREEN

(Pyrola asarifolia)

$\begin{array}{lll}2 & 0-4 & 75 \\ 2 & 0-10 & 50\end{array}$

$4 \quad 0-18 \quad 36$

$1 \quad 0-3 \quad 43$

$1 \quad 0-5 \quad 29$

$4 \quad 0-19 \quad 36$

$1 \quad 0-2 \quad 64$

Grasses

SEDGE

(Carex spp.)

HAIRY WILDRYE

(Elymus innovatus)

Moss

\section{ENVIRONMENTAL VARIABLES}

MOISTURE REGIME: SUBMESIC TO MESIC

NUTRIENT REGIME: SUBMESOTROPHIC TO MESOTROPHIC

ELEVATION: 1407 (1330-1510)M

ASPECT: NORTHERLY

SLOPE: $14(1-35) \%$

SOIL DRAINAGE: WELL TO RAPIDLY

Forage Production (KG/HA)

GRASS $\quad 60(2-148)$

FORB 138(60-246)

SHRUB 3(0-12)

TOTAL 201(66-394)

\section{SUGGESTED GRAZING CAPACITY}

NON-USE 


\section{E12a: Sw/Horsetail \\ (Picea glauca/Equisetum arvense)}

$\mathbf{n}=4$ This community type represents one of the wettest and most nutrient-rich forest conditions in the Montane. Seepage and high water tables can be expected. Nutrient levels are high resulting in high diversity in shrub and forb layers. Generally, there is little palatable forage for domestic livestock and this community type should be rated as non-use.

\section{PLANT COMPOSITION CANOPY COVER (\%) MEAN RANGE CONST.}

\section{TREES}

WHITE SPRUCE

(Picea glauca)

$70 \quad 69-70 \quad 100$

BALSAM POPLAR

(Populus balsamifera)

$4 \quad 0-10 \quad 50$

\section{SHRUBS}

PRICKLY ROSE

(Rosa acicularis)

$2 \quad 1-3 \quad 100$

\section{FORBS}

HORSETAIL

(Equisetum arvense) 33

(Geranium richardsonii) 6

DANDELION

$\begin{array}{llll}\text { (Taraxacum officinale) } & 2 & 1-3 & 100\end{array}$

CANADA VIOLET

(Viola canadensis)

$8 \quad 0-30 \quad 25$

GRASSES

Marsh reedgrass

(Calamagrostis canadensis)

Moss

$25 \quad 20-78 \quad 100$

\section{$0-3 \quad 25$}

\section{ENVIRONMENTAL VARIABLES}

MOISTURE REGIME: SUBHYGRIC

NUTRIENT REGIME: PERMESOTROPHIC

ELEVATION: 1391(1385-1510)M

ASPECT: NORTHERLY

SLOPE: $14(1-35) \%$

SOIL DRAINAGE: WELL TO RAPIDLY

\section{Forage Production (KG/HA)}

$\begin{array}{lc}\text { GRASS } & 28 \\ \text { FORB } & 332 \\ \text { SHRUB } & 124 \\ \text { TOTAL } & 484\end{array}$

\section{SUGgESTED GRAZING CAPACITY} NON-USE 


\section{E12b: Sw/Silverberry/Horsetail \\ (Picea glauca/Elaeagnus commutata/Equisetum arvense)}

$\mathbf{n}=1 \quad$ This community type was described by Thompson and Hansen (2002) on an old floodplain bar that was 0.5 to $1.0 \mathrm{~m}$ above the current water table. The community represents succession to a Sw/Horsetail dominated type. As more sediment is deposited over the gravel it will favour the growth of horsetail over silverberry. Silverberry is common on gravelly river bars, but as the sediment increases and the drainage becomes poorer silverberry will decline in cover. There is little forage available for domestic livestock in this community type and it should be rated as non-use.

\section{PLANT COMPOSITION CANOPY COVER (\%)} MEAN RANGE CONST.

\section{TREES}

BALSAM POPLAR

(Populus balsamifera) $20 \quad-\quad 100$ WHITE SPRUCE

(Picea glauca)

$30 \quad-\quad 100$

\section{SHRUBS}

SILVERBERRY

$\begin{array}{lll}\text { (Elaeagnus commutata) } & 90 \quad-\quad 100\end{array}$

BEBB WILLOW

(Salix bebbiana)

$10 \quad-\quad 100$

FORBS

STRAWBERRY

(Fragaria virginiana) $3 \quad-\quad 100$

FIELD HORSETAIL

(Equisetum arvense)

$40 \quad-\quad 100$

GRASSES

BALTIC RUSH

(Juncus balticus)
MOISTURE REGIME: SUBHYGRIC

NUTRIENT REGIME: PERMESOTROPHIC

ELEVATION: $1231 \mathrm{M}$

SLOPE: $0 \%$

ASPECT: VARIABLE

SOIL DRAINAGE: WELL

\section{FORAGE PRODUCTION (KG/HA)}

GRASS $\quad 100$

FORB $\quad 401$

SHRUB 52

TOTAL $\quad 553 *$ Estimate

\section{SUGGESTED GRAZING CAPACITY}

NON-USE 


\section{E13: Pl/Thimbleberry (Pinus contorta/Rubus parviflorus)}

$\mathbf{n}=\mathbf{5}$ Nutrient rich seepage occurs on this community type at some point in the growing season favouring the growth of thimbleberry. On these sites thimbleberry is very common south of the Crowsnest Pass and is generally replaced by cow parsnip north of the Pass. Succession on these sites will be from aspen to pine and then to white spruce. Forage productivity on these sites is generally quite high because of the favourable moisture and nutrient conditions. Thimbleberry is generally unpalatable to livestock, but if the site has an abundance of cow parsnip it may be extensively utilized. This community type should be rated as secondary range.

PLANT COMPOSITION CANOPY COVER (\%) MEAN RANGe CONST.

\section{TREES}

LODGEPOLE PINE

(Pinus contorta)

WHITE SPRUCE

(Picea glauca)

$\begin{array}{lll}48 & 20-65 & 100 \\ 2 & 0-10 & 20\end{array}$

\section{SHRUBS}

THIMBLEBERRY

(Rubus parviflorus)

WHITE MEADOWSWEET

(Spiraea betulifolia)

32

5-55 $\quad 100$

$9 \quad 1-14 \quad 100$

\section{FORBS}

HEART-LEAVED ARNICA (Arnica cordifolia)

LINDLEY'S ASTER

(Aster ciliolatus)

STRAWBERRY

(Fragaria virginiana)

FIELD HORSETAIL

(Equisetum arvense)

COW PARSNIP

(Heracleum lanatum)

$5 \quad 4-6 \quad 100$

$\begin{array}{lll}2 & 1-7 & 100\end{array}$

$2 \quad 1-4 \quad 100$

$6 \quad 0-15 \quad 40$

\section{GRASSES}

PINEGRASS

(Calamagrostis rubescens)4

BROME

(Bromus vulgaris)
$0-12 \quad 60$

$0-6 \quad 60$

\section{ENVIRONMENTAL VARIABLES}

MoISTURE REGIME: MESIC

NUTRIENT REGIME: PERMESOTROPHIC

ELEVATION:1588 (1478-1680) M

SLOPE: $18(7-37) \%$

ASPECT: VARIABLE

SOIL DRAINAGE: WELL

\section{Forage Production (KG/Ha)}

GRASS 320(40-1132)

FORB 460(142-1152)

SHRUB 191(0-616)

TOTAL 976(398-1346)
SUGGESTED GRAZING CAPACITY

$1.5 \mathrm{HA} / \mathrm{AUM}$ 


\section{E14: P1/Thimbleberry/Beargrass \\ (Pinus contorta/Rubus parviflorus/Xerophyllum tenax)}

$\mathbf{n = 1}$ This community type is very similar to the P1/Thimbleberry community type previously described, but contains a high cover of beargrass. Archibald et al. (1996) recognized these beargrass-dominated community types in the extreme southern portion of the subregion. Beargrass is well suited to growing on hillsides and dry subalpine meadows and appears to indicate the transition from the lower Montane subregion to the upper Subalpine subregion. The tender seed pods are often eaten by small rodents and elk. In the winter Mountain goats often eat the leaves (Craighead et al. 1963). The tough leaves of beargrass are unpalatable to livestock.

\section{Plant Composition Canopy Cover (\%)} MEAN RANGe CONST.

\section{TREES}

LODGEPOLE PINE

(Pinus contorta)

WHITE SPRUCE

(Picea glauca)

\section{SHRUBS}

THIMBLEBERRY

(Rubus parviflorus)

WILLOW

(Salix spp.)

WHITE MEADOWSWEET

(Spiraea betulifolia)

\section{FORBS}

BEARGRASS

(Xerophyllum tenax)

GROUSEBERRY

(Vaccinium scoparium)

VEINY MEADOW RUE

(Thalictrum venulosum)

EARLY BLUE VIOLET

(Viola adunca)

WILD STRAWBERRY

(Fragaria virginiana)

34

19

17

45

3

100

100

100

100

100

54

23

9

3

9

\section{GRASSES}

BROME

(Bromus vulgaris)

100

100

100

100

100

\section{ENVIRONMENTAL VARIABLES}

MOISTURE REGIME: SUBMESIC

NUTRIENT REGIME: MESOTROPHIC

ELEVATION: $1494 \mathrm{M}$

SLOPE: $15 \%$

ASPECT: SOUTHWEST

SOIL DRAINAGE: RAPIDLY

\section{Forage Production (KG/HA)}

$\begin{array}{ll}\text { GRASS } & 80 \\ \text { FORB } & 856 \\ \text { SHRUB } & 1010 \\ \text { TOTAL } & 1946\end{array}$

SUGgested GRAZING CAPACITY

NON-USE 


\section{E15: PI/River alder-Thimbleberry \\ (Pinus contorta/Alnus tenuifolia-Rubus parviflorus)}

$\mathbf{n}=\mathbf{1}$ This community type is very similar to the previously described P1/Thimbleberry and $\mathrm{P} 1 /$ Thimbleberry/Beargrass community types, but contains river alder. River alder tends to be found growing on nutrient seepage areas with high water tables. This community type is probably moister than the other $\mathrm{Pl}$ Thimbleberry dominated types, but dries out at some time during the growing season which favours the growth of thimbleberry. The high cover of alder limits the light reaching the forest floor and results in low production of grass and forbs. The majority of the total production comes from alder which is unpalatable and generally inaccessible to livestock. Consequently, this community type would be rated as non-use.

\section{PLANT COMPOSITION CANOPY COVER (\%)} MEAN RANGe CONST.

\section{TREES}

BALSAM POPLAR

(Populus balsamifera)

LODGEPOLE PINE

(Pinus contorta)

10

\section{SHRUBS}

RIVER ALDER

(Alnus tenuifolia)

THIMBLEBERRY

(Rubus parviflorus)

GREEN ALDER

(Alnus crispa)

ROSE

(Rosa acicularis) 10

FORBS

DEWBERRY

(Rubus pubescens)

FIELD HORSETAIL

$\begin{array}{llll}\text { (Equisetum arvense) } & 5 & - & 100\end{array}$

LINDLEY'S ASTER

(Aster ciliolatus)

Grasses

MARSH REEDGRASS

(Calamagrostis canadensis)2 - 100

HAIRY WILDRYE

$\begin{array}{llll}\text { (Elymus innovatus) } & 1 & - & 100\end{array}$
100

\section{ENVIRONMENTAL VARIABLES}

MOISTURE REGIME: SUBHYGRIC

NUTRIENT REGIME : PERMESOTROPHIC

ELEVATION: $1300 \mathrm{M}$

SLOPE: $12 \%$

ASPECT: NORTH

SOIL DRAINAGE: MODERATELY WELL

Forage Production (KG/Ha)

TOTAL $\quad 800 \mathrm{KG} / \mathrm{HA}$ *

(*ESTIMATED)

100

100

SUGGESTED GRAZING CAPACITY

NON-USE 


\section{E16: Sw/Thimbleberry \\ (Picea glauca/Rubus parviflorus)}

$\mathbf{n}=\mathbf{1}$ This community type is very similar to the P1/Thimbleberry dominated community types previously described, but is successionally more advanced. Succession on the thimbleberry dominated ecosites will be from aspen to pine and then to white spruce (Archibald et al. 1996). The northerly aspect of this particular community type has allowed the site to escape disturbance by fire and succession has occurred to white spruce. Note as succession occurs there is a corresponding drop in forage productivity from $500-600 \mathrm{~kg} / \mathrm{ha}$ in the $\mathrm{Pl}$ community types to $250 \mathrm{~kg} / \mathrm{ha}$ in this community type. This community type would be rated as non-use for domestic livestock.

Plant Composition Canopy Cover (\%) MEAN RANGE CONST.

\section{TREeS}

WHITE SPRUCE

(Picea glauca)

$75 \quad-\quad 100$

\section{SHRUBS}

PRICKLY ROSE

(Rosa acicularis)

THIMBLEBERRY

(Rubus parviflorus)

WHITE MEADOWSWEET

(Spiraea betulifolia)

\section{FORBS}

SHOWY ASTER

(Aster conspicuus)

TWINFLOWER

(Linnaea borealis)

HEART-LEAVED ARNICA

(Arnica cordifolia)

MOSSES
$1 \quad-\quad 100$

$11 \quad 100$

$1 \quad-\quad 100$

\section{ENVIRONMENTAL VARIABLES}

MOISTURE REGIME: MeSIC

NUTRIENT REGIME: MESOTROPHIC

ELEVATION:1570M

SLOPE: $10 \%$

ASPECT: NORTH

SOIL DRAINAGE: WELL

\section{Forage Production (KG/HA)}

$\begin{array}{ll}\text { GRASS } & 18 \\ \text { FORB } & 130 \\ \text { SHRUB } & 100 \\ \text { TOTAL } & 248\end{array}$

Suggested GRAZING CAPACITY

NON-USE 


\section{E17: Sb-Lt/Labrador tea \\ (Picea mariana-Larix laricina/Ledum groenlandicum)}

$\mathbf{n = 1}$ This community type occurs in association with lowland boggy areas. The water table under this type has begun to drop which has allowed succession toward a white spruce-dominated community. Generally, black spruce-larch dominated communities are considered successionally mature because of poor drainage, acidic soils and low soil nutrients which prevent succession to white spruce. This community type is likely flooded in the spring, therefore, it may provide a scource of water for livestock early in the year. However, due to poor access and the limited number of palatable plants available, this community type would be considered non-use.

\section{PLANT COMPOSITION CANOPY COVER (\%)} MEAN RANGe CONST.

\section{TREES}

BLACK SPRUCE
(Picea mariana)

WHITE SPRUCE

(Picea glauca)

LARCH

(Larix laricina)

20

20

5

\section{SHRUBS}

LABRADOR TEA

(Ledum groenlandicum) 1

MYRTLE-LEAVED WILLOW

(Salix myrtillifolia)

\section{ENVIRONMENTAL VARIABLES}

MOISTURE REGIME: SUBHYGRIC

NUTRIENT REGIME : SUBMESOTROPHIC

ELEVATION: $1220 \mathrm{M}$

SOIL DRAINAGE: POORLY

Forage Production (KG/HA)

TOTAL $500 \mathrm{KG} / \mathrm{HA}^{*}$

(*ESTIMATED)

\section{FORBS}

COMMON BEARBERRY

(Arctostaphylos uva-ursi) $5 \quad$ - $\quad 100$

TWINFLOWER

(Linnaea borealis) $\quad 5 \quad-\quad 100$

DWARF SCOURING RUSH

(Equisetum scirpoides) $4 \quad-\quad 100$

COMMON HORSETAIL

(Equisetum arvense) $3 \quad$ - $\quad 100$

NORTHERN COMANDRA

(Geocaulon lividum) $\quad 2 \quad$ - $\quad 100$

\section{GRASSES}

SHEATHED SEDGE

(Carex vaginata)

HAIRY WILDRYE

(Elymus innovatus)

100

100

00 


\section{E18: Se/Grouseberry/Moss \\ (Picea engelmannii/Vaccinium scoparium/Moss)}

$\mathbf{n = 1}$ This community represents a subalpine forested community type with mesic moisture regimes and medium nutrient regimes. Subalpine fir, Englemann spruce, false azalea and grouseberry rarely occur at lower elevations and therefore are characteristic of the subalpine environment. The Castle area of the province is unusual in that the subalpine forested communities can be found at lower montane elevations and the montane grasslands can be found at alpine and subalpine elevations. Clearly there is a strong overlap between the Montane and Subalpine subregions of this area of the province. It is for this reason that the forested community types for the Castle area are described in this guide.

\section{PLANT COMPOSITION CANOPY COVER (\%)} MEAN RANGE CONST.

\section{TREES}

ENGELMANN SPRUCE

(Picea engelmannii)

WHITE SPRUCE

(Picea glauca)

\section{SHRUBS}

THIMBLEBERRY

(Rubus parviflorus)

FALSE AZALEA

(Menziesia ferruginea) $3 \quad$ - 100

GROUSEBERRY

(Vaccinium scoparium)

100

100

100

100

15

\section{FORBS}

FIREWEED

(Epilobium angustifolium) 17

WILD STRAWBERRY

(Fragaria virginiana)

(Penstemon confertus)

SMOOTH ASTER

(Aster laevis)

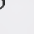

100

100

100

\section{ENVIRONMENTAL VARIABLES}

MoISTURE REGIME: MESIC

NUTRIENT REGIME: MESOTROPHIC

ELEVATION: $1530 \mathrm{M}$

ASPECT: EAST

SLOPE: $10 \%$

SOIL DRAINAGL: WELL

\section{Forage Production (KG/HA)}

$\begin{array}{ll}\text { GRASS } & 430 \\ \text { FORB } & 484 \\ \text { SHRUB } & 156 \\ \text { TOTAL } & 1064\end{array}$

SUGGESTED GRAZING CAPACITY

NON-USE

\section{GRASSES}

NORTHERN REEDGRASS

(Calamagrostis inexpansa)23 - 100

SLENDER WHEATGRASS

(Agropyron trachycaulum) $10 \quad-\quad 100$

Moss

$5 \quad-\quad 100$

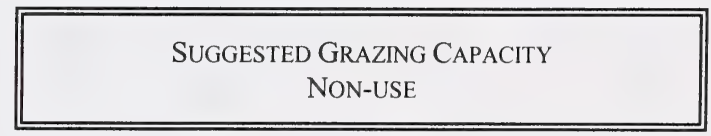




\section{E19. Se/Moss \\ (Picea engelmannii/Moss)}

$\mathbf{n}=3$ This community type is very similar to the previously described Se/Grouseberry community type, but lacks the cover of grouseberry. Grouseberry is well adapted to growing at higher elevations in the subalpine and is very common at timberline between the subalpine and alpine environments (Willoughby 1999). The lack of grouseberry in this community type may indicate warmer sites than the previously described Se/Grouseberry community. This community would be rated as non-use for domestic livestock.

\section{PLANT COMPOSITION CANOPY COVER (\%) MEAN RANGE CONST.}

\section{TREES}

ENGELMANN SPRUCE
(Picea engelmannii)

BALSAM POPLAR

(Populus balsamifera) $11 \quad 0-33 \quad 33$

SUBALPINE FIR

(Abies lasiocarpa)

$\begin{array}{lll}57 & 43-66 & 100 \\ 11 & 0-33 & 33 \\ 5 & 0-15 & 33\end{array}$

\section{SHRUBS}

THIMBLEBERRY

(Rubus parviflorus)

SNOWBERRY

WHITE MEADOWSWEET

(Spiraea betulifolia) $\quad 1 \quad 0-3 \quad 67$

\section{FORBS}

VEINY MEADOW RUE

(Thalictrum venulosum) 5

WILD STRAWBERRY

(Fragaria virginiana)

HEART-LEAVED ARNICA

(Arnica cordifolia) $\quad 10 \quad 0-29$

CREAM-COLORED VETCHLING

(Lathyrus ochroleucus)

SHOWY ASTER

(Aster conspicuus)

BUNCHBERRY

(Cornus canadensis) $\quad 5 \quad 0-14 \quad 33$

\section{GRASSES}

TALL TRISETUM

(Trisetum canescens) $\quad 3 \quad 0-9 \quad 33$

MosSES

$18 \quad 2-44 \quad 100$

\section{ENVIRONMENTAL VARIABLES}

MOISTURE REGIME: SUBMESIC TO MESIC

NUTRIENT REGIME: MESOTROPHIC

ELEVATION: $1561(1433-1798) \mathrm{M}$

SLOPE: $21(5-37) \%$

ASPECT: VARIABLE

SOIL DRAINAGE: WELL

\section{Forage Production (KG/HA)}

GRASS 60(28-82)

FORB 212(56-356)

SHRUB 62(0-108)

TOTAL 334(162-546)

\section{SUGGESTED GRAZING CAPACITY} NON-USE 


\section{E20:Fa-Pl-Sw/White meadowsweet/Pinegrass \\ (Abies lasiocarpa-Pinus contorta-Picea glauca/Spiraea betulifolia/Calamagrostis rubescens)}

$\mathbf{n}=12$ This community is indicative of the overlap between the Subalpine and Montane subregions of the Castle area. The overstory is dominated by subalpine fir a species characteristic of the subalpine environment, but the understory is dominated by white meadowsweet and pinegrass species characteristic of the montane environment. This community type occupies submesic to mesic sites, on moderate slopes with variable aspects. Forage productivity is moderate averaging $1200 \mathrm{~kg} / \mathrm{ha}$, but the majority of the understory vegetation is unpalatable. As a result this community should be only rated as secondary range.

PLANT COMPOSITION CANOPY COVER (\%) Mean Range Const.

\section{TreEs}

SUBALPINE FIR

(Abies lasiocarpa)

WHITE SPRUCE

(Picea glauca)

LODGEPOLE PINE

(Pinus contorta)

$20 \quad 0-75 \quad 83$

\section{SHRUBS}

SNOWBERRY

(Symphoricarpos occidentalis) $7 \quad 0-30 \quad 92$
WHITE MEADOWSWEET

$\begin{array}{llll}\begin{array}{l}\text { (Spiraea betulifolia) } \\ \text { THIMBLEBERRY }\end{array} & 6 & 0-25 & 83 \\ \begin{array}{l}\text { (Rubus parviflora) } \\ \begin{array}{l}\text { FALSE AZALEA } \\ \text { (Menziesii ferruginea) }\end{array}\end{array} & 2 & 0-11 & 50 \\ \end{array}$

FORBS

FIREWEED

(Epilobium angustifolium) 3

WESTERN MEADOW RUE

(Thalictrum occidentale) 2

WILD STRAWBERRY

(Fragaria virginiana) 16

CREAM-COLORED VETCHLING

(Lathyrus ochroleucus)

SHOWY ASTER

(Aster conspicuus)

$33 \quad 0-70$

92

$25 \quad 3-50 \quad 100$

$20 \quad 0-75 \quad 83$

GRASSES

PINEGRASS

(Calamagrostis rubescens) $14 \quad 0-41 \quad 83$

SEDGE

(Carex spp.)

$2 \quad 0-10 \quad 42$

\section{ENVIRONMENTAL VARIABLES}

MOISTURE REGIME: MESIC TO

SUBMESIC

NUTRIENT REGIME : MESOTROPHIC

ELEVATION: 1592 (1493-1981)M

SLOPE: $14(3-40) \%$

ASPECT: VARIABLE

SOIL DRAINAGE: RAPIDLY

\section{FORAGE PRODUCTION (KG/HA)}

GRASS $\quad 845(78-4100)$

FORB 537(152-910)

SHRUB $177(0-682)$

TOTAL 1480(462-4482)

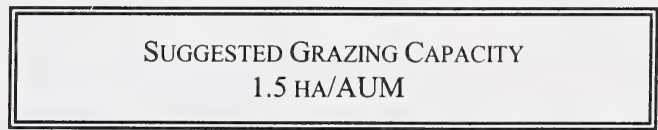




\section{E21: Fa-Se/Heart-leaved arnica (Abies lasiocarpa-Picea engelmannii/Arnica cordifolia)}

$\mathbf{n}=3$ This community type is very similar to the Se/Moss community previously described, but contains a high cover of subalpine fir. Succession in the subalpine is from lodgepole pine to Engelmann spruce and subalpine fir (Archibald et al. 1996). This community type appears to represent the climatic climax for sites with subalpine environments in the Castle area of the province. The northerly aspects of the two described sites probably allowed them to escape the recent fire history and undergo succession. As these forested sites succeed towards climax there is very little light reaching the forest floor. As a result, there is little forage for domestic livestock and this community would be rated as non-use

\section{Plant COMPOSITION CANOPY COVER (\%) MEAN RANGe CONST.}

\section{TREES}

SUBALPINE FIR

$\begin{array}{lcrc}\begin{array}{l}\text { (Abies lasiocarpa) } \\ \text { ENGELMANN SPRUCE }\end{array} & 55 & 25-80 & 100 \\ \begin{array}{l}\text { (Picea engelmannii) } \\ \text { Pic }\end{array} & 21 & 15-30 & 100\end{array}$

\section{SHRUBS}

THIMBLEBERRY

(Rubus parviflorus)

FALSE AZALEA

(Menziesia ferruginea)

GREEN ALDER

(Alnus crispa)

\section{FORBS}

HEART- LEAVED ARNICA

(Arnica cordifolia)

VEINY MEADOW RUE

(Thalictrum venulosum) 3

ONE FLOWERED WINTERGREEN

(Moneses uniflora) 2

SUGARSCOOP

$\begin{array}{llll}\text { (Tiarella unifoliata) } & 2 & 0-3 & 67\end{array}$

GRASSES

SEDGE

(Carex spp.)

Mosses

$24 \quad 20-27 \quad 100$

$0-2 \quad 67$

$10 \quad 0-22 \quad 67$

\section{ENVIRONMENTAL VARIABLES}

MoISTURE REgIME： MESIC

NUTRIENT REGIME : MESOTROPHIC

ELEVATION: 1760(1740-1788)M

SLOPE: $25(21-30) \%$

ASPECT: NORTHERLY

SOIL DRAINAGE: WeLL

\section{Forage Production (KG/HA)}

GRASS $\quad 16(0-48)$

FORB 153(0-356)

SHRUB 239(0-718)

TOTAL 408(48-1074)

\section{SUGGESTED GRAZING CAPACITY} NON-USE 


\section{E22: Se/Clover-Oxeye daisy \\ (Picea engelmannii/Trifolium repens-Chrysanthemum leucanthemum)}

$\mathbf{n}=1$ This community type represents a forested community type that has been heavily utilized by livestock. The heavy utilization has allowed clover and oxeye daisy to invade into the understory. Once established oxeye daisy is very invasive and difficult to control. The authors have seen whole fields taken over by this plant species. This plant is unpalatable to livestock so when invasion occurs there is a corresponding drop in forage production.

\section{Plant Composition CANOPY Cover (\%)} MEAN RANGe Const.

\section{TREES}

SUBALPINE FIR

(Abies lasiocarpa)

ENGELMANN SPRUCE

(Picea engelmanii)

12

11

\section{SHRUBS}

SASKATOON

(Amelanchier alnifolia)

WHITE MEADOWSWEET

(Spiraea betulifolia)

THIMBLEBERRY

(Rubus parviflora)

4

\section{FORBS}

OX-EYE DAISY

(Chrysanthemum

leucanthemum)

CLOVER

(Trifolium repens)

TALL BILBERRY

(Vaccinium myritillus)

WILD STRAWBERRY

(Fragaria virginiana)

TWINFLOWER

(Linnaea borealis)

DANDELION

(Taraxacum offincinale)

\section{GRASSES}

SEDGE

(Carex spp.)

PINEGRASS

(Calamagrostis rubescens)4

\section{ENVIRONMENTAL VARIABLES}

MoISTURE REGIME: MESIC

NUTRIENT REGIME: MESOTROPHIC

ELEVATION: $1557 \mathrm{M}$

SLOPE: $9 \%$

ASPECT: EAST

SOIL DRAINAGE: WELL

Forage ProduCtion (KG/HA)

$\begin{array}{ll}\text { GRASS } & 150 \\ \text { FORB } & 88 \\ \text { SHRUB } & 366 \\ \text { TOTAL } & 604\end{array}$

\section{SUGGESTED GRAZING CAPACITY $3.8 \mathrm{HA} / \mathrm{AUM}$}

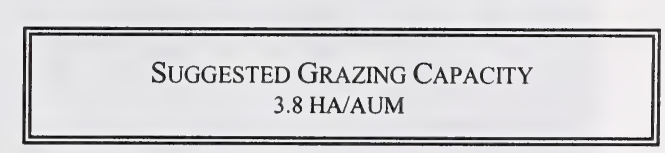




\section{MONTANE SUBREGION}

\section{MIXEDWOOD COMMUNITY TYPES}

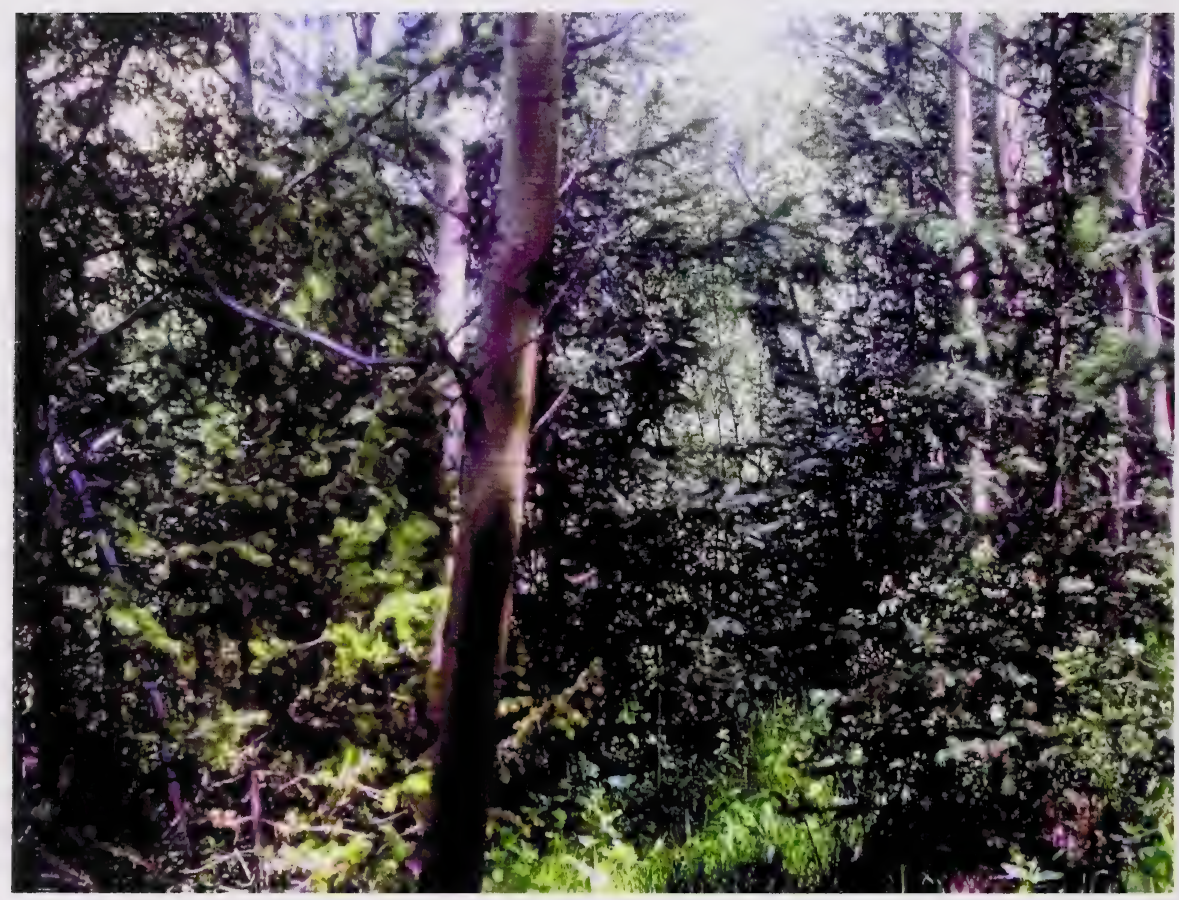

Photo 9: This represents an Aw-Sw mixedwood community type. There is a good forage base under the aspen, however as the spruce cover increases productivity will decline. 


\section{Key to Mixedwood community type}

1. Communities dominated by subalpine species such as Engelmann spruce, and subalpine fir....... 2 Communities do not have subalpine species, instead are dominated by Lodgepole pine, White spruces, and Douglasfir. 4

2. Community is grazed as indicated by the presence of Timothy, Dandelion, Clover, Canada thistle, and Kentucky bluegrass.. Aw-Fa-Se/Timothy

Snowberry dominates the understory.. 3

3. Subalpine fir dominates the overstory, and snowberry and Pinegrass dominate the understorey Aw-Fa/Snowberry/Pinegrass

Englemann spruce dominates the overstory. Sites are on moist north facing slopes at lower slope positions where seepage occurs in Spring and after heavy rainfalls. ..Spruce-Pb/Snowberry

4. Aspen, Balsam poplar, Lodgepole pine and White spruce dominated communities.

Aspen and Douglas fir dominated communities.

5. Moist sites containing Balsam poplar.

Drier sites dominated by Aspen, Lodgepole pine, and White spruce.

6. Site found in moist, lower slope positions where seepage occurs in the spring or after heavy rainfall.

Snowberry dominates the understory.

Spruce-Pb/Snowberry

Site found in moist, lower slope positions where seepage occurs in the spring or after heavy rainfall.

Pinegrass dominates the understory.

Aw-Pb-Sw/Pinegrass

7. Snowberry dominates the understory. Sites are mesic with medium nutrient regimes.

Pl-Aw/Snowberry/Kentucky bluegrass

Dwarf scouring rush, Blueberry, Yellow mountain avens, Pinegrass, Marsh reedgrass, or Buffaloberry, Hairy wildrye dominate the understory... 8

8. Dwarf scouring rush dominates the understory. Site occurs at moist, nutrient rich, lower slope positions, representing the wettest and most rich conditions in the Montane subregion...Sw-Aw/Scouring rush f12

Blueberry, Yellow mountain avens, Pinegrass, Marsh reedgrass, or Buffaloberry, Hairy wildrye dominate the understory.

9

9. Blueberry dominates the understorey.....

Aw-Sw/blueberry

Yellow mountain avens, Pinegrass, Marsh reedgrass, or Buffaloberry, Hairy wildrye dominate the understory

10. Yellow mountain avens dominate the understory (gravelly river and creek flood plains)...

.Sw-Pl-Pb/Yellow Mtn. avens $\underline{\mathrm{f}}$

Pinegrass, Marsh reedgrass, or Buffaloberry, Hairy wildrye dominate the understory.....

.Aw-Pl/Pinegrass

11. Pinegrass dominates the understory.

Marsh reedgrass, or Buffaloberry, Hairy wildrye dominate the understory.

.Aw-Pl/Marsh reedgrass

12. Marsh reedgrass dominates the understory......

Buffaloberry, Hairy wildrye dominate the understory.......................Aw /Buffaloberry/Hairy wildrye

13. Moister sites(dominated by white meadowsweet, or pinegrass).....

Drier sites. Dominated by Bearberry.....

Aw-Fd/Bearberry

14. White meadowsweet dominates the understory Pinegrass dominates the understory. Aw-Fd/White meadowsweet .Fd-Aw/Pinegrass 


\section{F1: Aw-Fd/Bearberry \\ (Populus tremuloides-Pseudotsuga menziesii/Arctostaphylos uva-ursi)}

$\mathbf{n}=\mathbf{2}$ This community represents an aspen dominated community type that is undergoing succession to douglas fir. It is part of the bearberry ecosite described by Archibald et al. (1996). This ecosite occupies dry upper slope positions with south exposures and coarse textured soils. Forage production on this site will be low because of the dry site conditions and livestock will have a difficulty accessing the upper slope position. This community should be rated as secondary range

\section{PLANT COMPOSITION CANOPY COVER (\%)} MEAN RANGE CONST.

\section{TREES}

ASPEN

(Populus tremuloides) $\quad 28 \quad 20-32 \quad 100$

DOUGLAS-FIR

$\begin{array}{llll}\text { (Pseudotsuga menziesii) } & 22 & 21-22 & 100\end{array}$

\section{SHRUBS}

SASKATOON

$\begin{array}{llll}\text { (Amelanchier alnifolia) } \quad 6 & 3-8 \quad 100\end{array}$

CREEPING JUNIPER

(Juniperus horizontalis) $\quad 6 \quad 0-12 \quad 50$

BUFFALOBERRY

(Shepherdia canadensis) $\quad 3 \quad 2-3 \quad 100$

\section{FORBS}

BEARBERRY

(Arctostaphylos uva-ursi) 48

43-52 100

COMMON YARROW

(Achillea millefolium) $2 \quad 1-3 \quad 100$

STRAWBERRY

$\begin{array}{llll}\text { (Fragaria virginiana) } & 6 & 3-9 & 100\end{array}$

CUT-LEAVED ANEMONE

$\begin{array}{llll}\text { (Anemone multifida) } & 2 & 1-2 & 100\end{array}$

\section{GRASSES}

SEDGE

(Carex spp.)

6

SLENDER WHEAT GRASS

(Agropyron trachycaulum) $20-3 \quad 100$

PINEGRASS

(Calamagrostis rubescens) $6 \quad 1-9 \quad 100$

ROUGH FESCUE

$\begin{array}{llll}\text { (Festuca scabrella) } & 9 & 1-16 & 100\end{array}$

\section{ENVIRONMENTAL VARIABLES}

MOISTURE REGIME: SUBMESIC

NUTRIENT REGIME: SUBMESOTROPHIC-MESOTROPHIC

ELEVATION: 1653(1645-1661) M

SOIL DRAINAGE: RAPIDLY

SLOPE: $12(10-15) \%$

ASPECT: SOUTHERLY

\section{Forage Production (KG/HA)}

$\begin{array}{ll}\text { GRASS } & 418 \\ \text { FORB } & 190 \\ \text { TOTAL } & 608\end{array}$

SUGGESTED GRAZING CAPACITY

$3.0 \mathrm{HA} / \mathrm{AUM}$ 


\section{F2: Sw-PI-Pb/Yellow Mtn. avens \\ (Picea glauca-Pinus contorta-Populus balsamifera/Dryas drummondii)}

$\mathbf{n}=1$ This community is typical of dry, gravelly river flats with nutrient poor soils. It is similar to the Yellow Mtn avens /Junegrass community type previously described, but this community type is successionally more advanced. The poor soil conditions limits the forage productivity and amount of regrowth after grazing. This community type should be raied as non-use.

Plant COMPOSITION CANOPY COVER (\%) MEAN RANGe Const.

TREES

WHITE SPRUCE

(Picea glauca)

LODGEPOLE PINE

(Pinus contorta)

BALSAM POPLAR

(Populus balsamifera)

SHRUBS

BUFFALOBERRY

(Shepherdia canadensis) $4 \quad-\quad 100$

PRICKLY ROSE

(Rosa acicularis) $1 \quad$ - 100

FORBS

YELLOW MTN. AVENS

(Dryas drummondii)

SHOWY ASTER

(Aster conspicuus)

LINDLEY'S ASTER

(Aster ciliolatus) 3

SHOWY LOCOWEED

(Oxytropis splendens)

GRASSES

CANADA BLUEGRASS

(Poa compressa)

$$
39
$$

20

17

100

$12 \quad-\quad 100$

$7 \quad-\quad 100$

100

100

100

\section{ENVIRONMENTAL VARIABLES}

MOISTURE REGIME: SUBMESIC

NUTRIENT REGIME: MESOTROPHIC

ELEVATION: 1547 M

SLOPE: $1 \%$

ASPECT: NORTH

SOIL DRAINAGE: RAPIDLY

Forage Production (KG/HA)

$\begin{array}{ll}\text { GRASS } & 152 \\ \text { FORB } & 252 \\ \text { SHRUB } & 40 \\ \text { TOTAL } & 444\end{array}$

SUGGESTED GRAZING CAPACITY

NON-USE 


\section{F3: Aw-PI/Buffaloberry/Hairy wildrye \\ (Populus tremuloides-Pinus contorta/Shepherdia canadensis/Elymus innovatus)}

$\mathbf{n = 1}$ This community occurs on submesic, well drained, south and west-facing slopes. It is very similar to the $\mathrm{P} 1 /$ Buffaloberry/Pinegrass community type previously described, but is in an earlier successional stage. The forage productivity on this community is only moderate and should be rated as secondary range.

PLANT COMPOSITION CANOPY COVER (\%) MEAN RANGe CONST.

\section{TREES}

ASPEN

$\begin{array}{llll}\text { (Populus tremuloides) } & 43 \quad-\quad & 100\end{array}$

LODGEPOLE PINE

(Pinus contorta)

$21 \quad-\quad 100$

\section{SHRUBS}

SNOWBERRY

(Symphoricarpos occidentalis)12 -

SASKATOON

(Amelanchier alnifolia)

CANADA BUFFALOBERRY

(Shepherdia canadensis) 15

\section{FORBS}

STRAWBERRY

(Fragaria virginiana) $\quad 9 \quad-\quad 100$

CREEPING MAHONIA

(Berberis repens)

YELLOW PEAVINE

(Lathyrus ochroleucus) $\quad 2 \quad$ - $\quad 100$

DANDELION

(Taraxacum officinale)

\section{GRASSES}

HAIRY WILD RYE

(Elymus innovatus)

PINEGRASS

(Calamagrostis rubescens) 14
100

100

100

\section{ENVIRONMENTAL VARIABLES}

MOISTURE REGIME: SUBMESIC

NUTRIENT REGIME: MESOTROPHIC

ELEVATION: $1608 \mathrm{M}$

ASPECT: SOUTH

SLOPE: $7 \%$

SOIL DRAINAGE: RAPIDLY

Forage Production (KG/HA)

TOTAL $\quad 350 \mathrm{KG} / \mathrm{HA}^{*}$

(*EsTIMATED)

100

100

SugGESTED GRAZING CAPACITY

NON-USE 


\section{F4: Aw-P1/Pinegrass \\ (Populus tremuloides-Pinus contorta/Calamagrostis rubescens)}

$\mathbf{n = 1}$ This community type is dominated by an overstory of aspen and lodgepole pine, and represents the mid successional stage between an Aw/Pinegrass and P1/Pinegrass dominated community type. Pinegrass is generally unpalatable to livestock, but if grazed early in the spring they will utilize it as a forage source. The forage productivity of this community type is midway between the aspen dominated community $(1278 \mathrm{~kg} / \mathrm{ha})$ and the pine dominated community $(598 \mathrm{~kg} / \mathrm{ha})$. This community would be rated as secondary range.

\section{Plant Composition CANOPY Cover (\%) Mean Range Cosnt.}

\section{TREES}

LODGEPOLE PINE

(Pinus contorta)

ASPEN

(Populus tremuloides)$$
40
$$$$
40
$$

SHRUBS

RosE

(Rosa acicularis)$$
100
$$

\section{FORBS}

TWINFLOWER

(Linnaea borealis)

$25 \quad-\quad 100$

(Fragaria virginiana)

LINDLEY'S ASTER

(Aster ciliolatus)

RICHARDSON'S GERANIUM

(Geranium richardsonii) 12

CREAM-COLORED VETCHLING

(Lathyrus ochroleucus)

\section{GRASSES}

PINE GRASS

(Calamagrostis rubescens)38 - 100

FRINGED BROME

$\begin{array}{lll}\text { (Bromus ciliatus) } & 13 & -\end{array}$

SLENDER WHEATGRASS

(Agropyron trachycaulum) $3 \quad$ - $\quad 100$

\section{ENVIRONMENTAL VARIABLES}

MOISTURE REGIME: MESIC

NUTRIENT REGIME: MESOTROPHIC

ELEVATION RANGE: $1554 \mathrm{M}$

SOIL DRAINAGE: MOD.WELL

\section{Forage Production (KG/HA)}

Grass $\quad 600$

FORB $\quad 384$

TOTAL $\quad 984$

SugGeSted GRAZING CAPACITY

$1.8 \mathrm{HA} / \mathrm{AUM}$

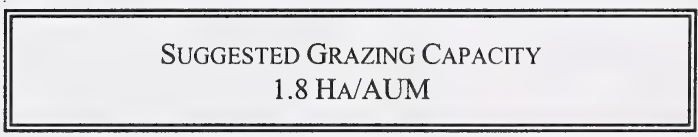




\section{F4a: Fd-Aw/Pinegrass \\ (Pseudotsuga menziesii-Populus tremuloides/Calamagrostis rubescens)}

$\mathbf{n = 4}$ This community type is dominated by an overstory of aspen and Douglas fir, and represents the mid successional stage between an Aw/Pinegrass and Fd dominated community types. Pinegrass is generally unpalatable to livestock, but if grazed early in the spring they will utilize it as a forage source. The forage productivity of this community type is midway between the aspen dominated community and theDouglas fir dominated communities. This community would be rated as secondary range.

PlaNT COMPOSITION CANOPY COVER (\%) MeAN Range Const.

TREES

DOUGLAS FIR

$\begin{array}{lccc}\begin{array}{l}\text { (Pseudotsuga menziesii) } \\ \text { ASPEN }\end{array} & 25 & 20-40 & 100 \\ \text { (Populus tremuloides) } & 31 & 20-40 & 100\end{array}$

\section{SHRUBS}

ROSE

(Rosa acicularis)

$4 \quad 1-10 \quad 100$

\section{FORBS}

MOUNTAIN DANDELION

(Agoseris glauca)

WILD STRAWBERRY

(Fragaria virginiana)

AMERICAN VETCH

(Vicia americana)

DANDELION

(Taraxacum officinale)

CREAM-COLORED VETCHLING

(Lathyrus ochroleucus) 2

$1 \quad 0-4 \quad 75$

$\begin{array}{lll}5 & 3-7 & 100\end{array}$

$1 \quad 1-2 \quad 100$

$1-4 \quad 100$

$1-3 \quad 100$

GraSSES

PINE GRASS

(Calamagrostis rubescens)21 15-28 100

HAIRY WILDRYE

(Elymus innovatus) $\quad 8 \quad 0-16 \quad 75$

SEDGE

(Carex spp.)

$1 \quad 0-2 \quad 75$

\section{ENVIRONMENTAL VARIABLES}

MOISTURE REGIME: MESIC TO SUBMESIC

NUTRIENT REGIME: MESOTROPHIC

ELEVATION RANGE: 1562(1433-1646)M

SOIL DRAINAGE: WELL

SLOPE: $5(0-10 \%)$

ASPECT: SOUTHEAST

\section{Forage Production (KG/HA)}

$\begin{array}{ll}\text { GRASS } & 905(662-1268) \\ \text { FORB } & 237(98-370) \\ \text { SHRUB } & 51(6-132) \\ \text { TOTAL } & 1192(1042-1372)\end{array}$

SUGGESTED GRAZING CAPACITY

$1.5 \mathrm{HA} / \mathrm{AUM}$ 


\section{F5: Aw-Sw/Blueberry \\ (Populus tremuloides-Picea glauca/Vaccinium spp.)}

$\mathbf{n}=\mathbf{2}$ This community represents the mid successional stage of a Sw/Moss dominated community type. The spruce dominated community types usually occupy lower slope positions with northerly aspects. These sites have escaped the recent fire history in the Montane and have succeeded to white spruce the climax species. There is very little growth of forbs and grass in this community type and should be rated as non-use for domestic livestock.

\section{Plant COMPOSITION CANOPY Cover (\%)} MEAN RANGe CONST.

TREES

WHITE SPRUCE

(Picea glauca)

$36 \quad 12-40 \quad 100$

ASPEN

(Populus tremuloides)

$33 \quad 30-35 \quad 100$

\section{SHRUBS}

TALL BILBERRY

(Vaccinium membranaceum)6 $\quad 0-11 \quad 50$

SNOWBERRY

(Symphoricarpos occidentalis) $4 \quad 0-8 \quad 50$

\section{FORBS}

WESTERN MEADOW RUE

(Thalictrum occidentale) 4

WILD STRAWBERRY

$\begin{array}{llll}\text { (Fragaria virginiana) } & 8 & 6-10 & 100\end{array}$

AMERICAN VETCH

(Vicia americana)

NORTHERN BEDSTRAW

(Galium boreale) 1

CREAM-COLORED VETCHLING

(Lathyrus ochroleucus) 2

\section{GraSSES}

PINE GRASS

(Calamagrostis rubescens) 3

MELIC GRASS

(Melica smithii)

VIRGINIA WILDRYE

(Elymus virginicus)

\section{ENVIRONMENTAL VARIABLES}

MOISTURE REGIME: MESIC

NUTRIENT REGIME: MESOTROPHIC

ELEVATION RANGE: $1524 \mathrm{M}$

ASPECT: NORTHERLY

SLOPE: $2 \%$

SOIL DRAINAGE: WELL

\section{Forage Production (KG/HA)}

$\begin{array}{ll}\text { GRASS } & 330 \\ \text { FORB } & 46 \\ \text { SHRUB } & 48 \\ \text { TOTAL } & 424\end{array}$

SUGGESTED GRAZING CAPACITY

NON-USE 


\section{F6: Aw-Fd/White meadowsweet \\ (Populus tremuloides-Pseudotsuga menziesii/Spiraea betulifolia)}

$\mathbf{n}=\mathbf{1}$ This community type represents an intermediate stage of succession between the Sw-Fd/White meadowsweet and $\mathrm{Aw} /$ White meadowsweet/Pinegrass dominated community types. White meadowsweet is indicative of sites with mesic moisture and medium nutrient regimes (Archibald et al. 1996). When this community succeeds to a conifer dominated type there will be insufficient forage for domestic livestock. Presently, with the high aspen cover there will be a moderate forage base and this community type should be rated as secondary range.

\section{Plant COMPOSITION CANOPY COVER (\%) MEAN RANGE CONST.}

\section{TREES}

DOUGLAS FIR

(Pseudotsuga menziesii) $40 \quad-\quad 100$

ASPEN

(Populus tremuloides) $36 \quad-\quad 100$

SHRUBS

WHITE MEADOWSWEET

(Spiraea betulifolia)

$19 \quad-\quad 100$

DWARF BILBERRY

(Vaccinium caespitosum)

PRICKLY ROSE

(Rosa acicularis)

FORBS

SHOWY ASTER

100
(Aster conspicuus)

GRACEFUL CINQUEFOIL

(Potentilla gracilis)

LINDLEY'S ASTER

(Aster ciliolatus)

STRAWBERRY

(Fragaria virginiana)

5

2

6

\section{GRASSES}

PINEGRASS

(Calamagrostis rubescens)4

HAIRY WILD RYE

(Elymus innovatus)

\section{ENVIRONMENTAL VARIABLES}

MOISTURE REGIME: MESIC

NUTRIENT REGIME: MESOTROPHIC

ELEVATION: 1593 M

ASPECT: SOUTH

SLOPE: $20 \%$

SOIL DRAINAGE: WELL

FORAGE PRODUCTION (KG/HA)

TOTAL $\quad 800 \mathrm{KG} / \mathrm{HA}^{*}$

(*ESTIMATED)

\section{SUGGESTED GRAZING CAPACITY}

$2.3 \mathrm{HA} / \mathrm{AUM}$ 


\section{F7: Aw-Pb-Sw/Pinegrass}

(Populus tremuloides-Populus balsamifera-Picea glauca/Calamagrostis rubescens)

$\mathbf{n}=1$ This community type occurs on moist, lower slope positions where seepage occurs in the spring or after heavy rainfall. Succession will be to a spruce dominated forest. The high tree cover limits the light reaching the forest floor. Consequently, only a moderate amount of forage is produced for domestic livestock.

\section{Plant COMPOSITION CANOPY COVER (\%)}

MEAN RANGE CONST

TREES

ASPEN

(Populus tremuloides)

BALSAM POPLAR

(Populus balsamifera)

WHITE SPRUCE

(Picea glauca)

\section{SHRUBS}

ROSE

(Rosa acicularis)

WHITE MEADOWSWEET

(Spiraea betulifolia)

FORBS

WILD WHITE GERANIUM

(Geranium richardsoni)

VEINY MEADOW RUE

(Thalictrum venulosum)

STRAWBERRY

(Fragaria virginiana)

TALL LUNGWORT

(Mertensia paniculata)

CREAM-COLORED VETCHLING

(Lathyrus ochroleucus) 1

\section{GraSSES}

PINEGRASS

(Calamagrostis rubescens) 8

HAIRY WILDRYE

(Elymus innovatus)

$25 \quad-\quad 100$

100

100

100

100

100

100

100

100

100

\section{ENVIRONMENTAL VARIABLES}

MOISTURE REGIME: MESIC

NUTRIENT REGIME: MESOTROPHIC

ELEVATION: 1372 M

ASPECT: WEST

SLOPE: $8 \%$

SOIL DRAINAGE: WELL

FORAGE PRODUCTION (KG/HA)

$\begin{array}{ll}\text { GRASS } & 122 \\ \text { FORB } & 282 \\ \text { SHRUB } & 28 \\ \text { TOTAL } & 412\end{array}$

\section{SUGGESTED GRAZING CAPACITY}

$4.4 \mathrm{HA} / \mathrm{AUM}$ 


\section{F8: Aw-Fa/Snowberry/Pinegrass}

(Populus tremuloides-Abies lasiocarpa/Symphoricarpos albus/Calamagrostis rubescens)

$\mathbf{n}=1$ This community is very similar to the Fa-Pl-Sw/White meadowsweet/Pinegrass previously described. This community was described in the Castle area and is indicative of the overlap between the Subalpine and Montane subregions. The overstory has a high cover of subalpine fir a species characteristic of the subalpine environment, but the understory is dominated by snowberry and pinegrass species characteristic of the montane environment. The forage productivity of this community type is moderate, but the majority of production is coming from snowberry which is generally unpalatable to livestock. This community should be rated as secondary range.

PlaNT COMPOSITION CANOPY COVER (\%) MEAN RANGE CONST

\section{TREES}

LODGEPOLE PINE

(Pinus contorta)

ASPEN

(Populus tremuloides) $\quad 48 \quad-\quad 100$

SUBALPINE FIR

(Abies lasiocarpa)

$10 \quad-\quad 100$

\section{SHRUBS}

SNOWBERRY

$\begin{array}{lll}\text { (Symphoricarpos albus) } & 59 & -\end{array}$

SASKATOON

$\begin{array}{llll}\text { (Amelanchier alnifolia) } & 5 & - & 100\end{array}$

WHITE MEADOWSWEET

(Spiraea betulifolia)

$1 \quad-\quad 100$

\section{FORBS}

CREEPING MAHONIA

(Berberis repens)

WESTERN MEADOW RUE

(Thalictrum occidentalis) $6 \quad-\quad 100$

WILD STRAWBERRY

$\begin{array}{llll}\text { (Fragaria virginiana) } & 6 & - & 100\end{array}$

LINDLEY'S ASTER

(Aster laevis)

$5 \quad-\quad 100$

\section{GRASSES}

PINEGRASS

(Calamagrostis rubescens) 16

\section{ENVIRONMENTAL VARIABLES}

MOISTURE REGIME: MESIC

NUTRIENT REGIME: MESOTROPHIC

ELEVATION RANGE: $1460 \mathrm{M}$

ASPECT: SOUTH TO SOUTHWEST

SLOPE: $9 \%$

SOIL DRAINAGE: WELL

\section{FORAGE PRODUCTION (KG/HA)}

$\begin{array}{ll}\text { GrASS } & 152 \\ \text { FORB } & 210 \\ \text { SHRUB } & 754 \\ \text { TOTAL } & 1116\end{array}$

SugGESTED GRAZING CAPACITY

1.6 HA/AUM 


\section{F8a: Aw-PI/Marsh reedgrass \\ (Populus tremuloides-Pinus contorta/Calamagrostis canadensis)}

$\mathbf{n}=1$ This community is very similar to the $\mathrm{Aw}-\mathrm{Pb} / \mathrm{Marsh}$ reedgrass community described which is found in moist lower slope positions throughout the Porcupine Hills. This community type is successional more advanced than the aspen, balsam poplar dominated community type. Continued succession in the absence of disturbance will be to white spruce. The forage productivity of this community type is moderate, but the majority of production is coming from pinegrass which is generally only palatable to livestock early in the spring. This community should be rated as secondary range.

\section{PLANT COMPOSITION CANOPY COVER (\%)} MEAN RANGE CONST

\section{TREES}

LODGEPOLE PINE

(Pinus contorta)

$20 \quad-\quad 100$

ASPEN

(Populus tremuloides) $50 \quad-\quad 100$

WHITE SPRUCE

(Picea glauca)

$5 \quad-\quad 100$

\section{SHRUBS}

ROSE

(Rosa acicularis)

DWARF BILBERRY

(Vaccinium caespitosum) $13 \quad$ - 100

\section{FORBS}

CREAM COLORED VETCHLING

(Lathyrus ochroleucus) 10

TALL LUNGWORT

$\begin{array}{llll}\text { (Mertensia paniculata) } & 6 & - & 100\end{array}$

WILD STRAWBERRY

(Fragaria virginiana) $4 \quad-\quad 100$

LINDLEY'S ASTER

(Aster laevis)

$19 \quad-\quad 100$

\section{GraSSES}

MARSH REEDGRASS

(Calamagrostis canadensis)17 - 100

FRINGED BROME

(Bromus cilatus)

\section{ENVIRONMENTAL VARIABLES}

MOISTURE REGIME: MESIC TO SUBHYGRIC

NUTRIENT REGIME :

MESOTROPHIC TO PERMESOTROPHIC

ELEVATION RANGE: 1523(1448-1645)M

ASPECT: VARIABLE

SLOPE: $0-1 \%$

SOIL DRAINAGE: WELLTO MOD. WELL

\section{FORAGE PRODUCTION (KG/HA)}

$\begin{array}{ll}\text { FORB } & 215(0-646) \\ \text { GRASS } & 1120(938-1342) \\ \text { TOTAL } & 1336(938-1728)\end{array}$

\section{SUGGested STOCKING RATE $1.4 \mathrm{HA} / \mathrm{AUM}$}




\section{F9: Pl-Aw/Snowberry/Kentucky bluegrass}

\section{(Pinus contorta-Populus tremuloides/Symphoricarpos occidentalis/Poa pratensis)}

$\mathbf{n}=1$ This community type represents an earlier successional stage of the P1/White meadowsweet and P1/Pinegrass community types. These communities occupy mesic sites with medium nutrient regimes (Archibald et al. 1996). It appears that this community type was grazed heavily in the past and then rested. Willoughby (1995) found that aspen stands that have been heavily grazed for prolonged periods have a low cover of native shrubs, forbs and grass species and a high cover of Kentucky bluegrass, clover and dandelion. This community has a high cover of Kentucky bluegrass, but it also has a high cover of native shrubs, forbs and grass, which may indicate that it has been grazed heavily to the point of Kentucky bluegrass invasion and then rested allowing recovery of the native species. This community is very productive for domestic livestock, but Kentucky bluegrass provides a poor source of forage for wintering wildlife.

\section{Plant Composition Canopy Cover (\%)} MEAN RANGE CONST.

\section{TREES}

LODGEPOLE PINE

(Pinus contorta) 30

ASPEN

(Populus tremuloides)

SHRUBS

SNOWBERRY

(Symphoricarpos

occidentalis)

WHITE MEADOWSWEET

(Spiraea betulifolia)

THIMBLEBERRY

(Rubus parviflora)

GROUND JUNIPER

(Juniperus communis)

FORBS

STRAWBERRY

$\begin{array}{llll}\text { (Fragaria virginiana) } 12 & - & 100\end{array}$

STICKY PURPLE GERANIUM

(Geranium viscosissimum)8 $8 \quad$ - 100

SMOOTH ASTER

(Aster laevis)

DANDELION

(Taraxacum officinale) $5 \quad-\quad 100$

AMERICAN VETCH

(Vicia americana)

4

GRASSES

KENTUCKY BLUEGRASS

(Poa pratensis)

21

100

PINEGRASS

(Calamagrostis rubescens)14 - 100

TIMOTHY

(Phleum pratense)

\section{ENVIRONMENTAL VARIABLES}

MOISTURE REGIME: MESIC

NUTRIENT REGIME: MESOTROPHIC

SOIL DRAINAGE: WeLL

ASPECT: WEST

SLOPE: $26 \%$

\section{FORAGE PRODUCTION (KG/HA)}

$\begin{array}{ll}\text { GRASS } & 668 \\ \text { FORB } & 774 \\ \text { SHRUB } & 506 \\ \text { TOTAL } & 1948\end{array}$

SUGGESTED GRAZING CAPACITY

$0.9 \mathrm{HA} / \mathrm{AUM}$ 


\section{F10: Aw-Fa-Se/Timothy \\ (Populus tremuloides-Abies lasiocarpa-Picea engelmannii/Phleum pratense)}

$\mathbf{n}=\mathbf{2}$ This community was described in the Castle area of the province and if left undisturbed would have likely succeeded to a Fa-Se/Heart lv'd arnica-dominated community type. Heavy grazing pressure has shifted the understory away from native species and allowed dandelion, clover, Canada thistle, timothy and Kentucky bluegrass to establish on the site. This change in species composition with increased grazing pressure is similar to work done by Willoughby (1995). The invasion of non-native species onto this site makes this community very productive for domestic livestock, but the presence of overgrazed communities indicates some type of distribution problem and the management of the disposition should be discussed with the permitees.

\section{Plant COMPOSITION CANOPY COVER (\%)}

\section{TREES}

ENGELMANN SPRUCE

(Picea engelmannii)

SUBALPINE FIR

(Abies lasiocarpa)

ASPEN

(Populus tremuloides)

$5 \quad 0-10 \quad 50$

$5 \quad 0-10 \quad 50$

$84 \quad 15-95 \quad 100$

MEAN RANGE CONST.

\section{SHRUBS}

SNOWBERRY

(Symphoricarpos

occidentalis,S. albus)

FORBS

WILD STRAWBERRY

(Fragaria virginiana)

DANDELION

(Taraxacum offincinale)

WILD WHITE GERANIUM

(Geranium richardsonii)

SMOOTH ASTER

(Aster laevis)

CANADA THISTLE

(Cirsium arvense)

Clover

(Trifolium repens)

GRASSES

TIMOTHY

(Phleum pratense)

KENTUCKY BLUEGRASS

(Poa pratensis)

MoUNTAIN BROME

(Bromus carinatus)

SLENDER WHEAT GRASS

(Agropyron trachycaulum) 3
12

9-14

100

$13 \quad 5-21 \quad 100$

$33 \quad 17-49 \quad 100$

$24 \quad 1-47 \quad 100$

$11 \quad 1-21 \quad 100$

$\begin{array}{lll}5 & 3-6 \quad 100\end{array}$

$20 \quad 0-40 \quad 50$

$25 \quad 12-36 \quad 100$

$11 \quad 0-21 \quad 50$

$7 \quad 1-13 \quad 100$

$0-6 \quad 100$

\section{ENVIRONMENTAL VARIABLES}

MoIstURE REGIME: MesiC

NUTRIENT REGIME: MESOTROPHIC

ELEVATION: 1402(1370-1434)M

SOIL DRAINAGE: WELL

FORAGE PRODUCTION (KG/HA)

$\begin{array}{ll}\text { GRASS } & 1328(968-1688) \\ \text { FORB } & 346(266-426) \\ \text { SHRUB } & 232(218-246) \\ \text { TOTAL } & 1906(1452-2360)\end{array}$

SUGGESTED GRAZING CAPACITY

$0.9 \mathrm{HA} / A U M$ 


\section{F11: Spruce-Pb/Snowberry}

(Picea glauca, P. engelmannii-Populus balsamifera/Symphoricarpos occidentalis)

$\mathbf{n}=3$ Archibald et al. (1996) described a similar Pb/Snowberry-dominated community on moist lower slope positions where seepage occurs in the spring and after heavy rainfalls. They felt succession would be to white spruce. This community is successionally more advanced than the $\mathrm{Pb} / \mathrm{Snowberry}$ dominated community type. Likely the northerly aspects of the 3 stands described allowed this community to escape the extensive fire history in the area. The high canopy cover of trees and shrubs limits the amount of light reaching the forest floor and therefore there is only moderate amounts of forage available for domestic livestock. This community type would be rated as secondary range.

\section{PLANT COMPOSITION CANOPY COVER (\%) MEAN RANGE CONST.}

\section{TREES}

SUBALPINE FIR

(Abies lasiocarpa)

$4 \quad 0-10 \quad 33$

ENGELMANN SPRUCE

(Picea engelmannii) $15 \quad 0-45 \quad 33$

BALSAM POPLAR

(Populus balsamifera) $\quad 16 \quad 0-15 \quad 66$

WHITE SPRUCE

(Picea glauca)

$5 \quad 0-10 \quad 66$

SHRUBS

THIMBLEBERRY

(Rubus parviflorus)

SNOWBERRY

(Symphoricarpos occidentalis

S. albus) 9

WHITE MEADOWSWEET

(Spiraea betulifolia)

1

FORBS

FIELD HORSETAIL

$\begin{array}{llll}\text { (Equisetum arvense) } & 8 & 1-15 & 100\end{array}$

LINDLEY'S ASTER

(Aster ciliolatus)

STRAWBERRY

$\begin{array}{llll}\text { (Fragaria virginiana) } & 4 & 3-5 & 100\end{array}$

CANADA VIOLET

(Viola canadensis)

DANDELION

(Taraxacum officinale)

NORTHERN BEDSTRAW

(Galium boreale)

GRASSES

MARSH REEDGRASS

(Calamagrostis canadensis) 7

\section{ENVIRONMENTAL VARIABLES}

MOISTURE REGIME: MESIC TO HYGRIC

NUTRIENT REGIME :

MESOTROPHIC TO PERMESOTROPHIC

ELEVATION: 1507(1455-1554)M

ASPECT: NORTHERLY

SLOPE: $2(0-7) \%$

SOIL DRAINAGE: WeLL

\section{FORAGE PRODUCTION (KG/HA)}

$\begin{array}{ll}\text { GrASS } & 97(20-252) \\ \text { FORB } & 681(232-1018) \\ \text { SHRUB } & 237(40-540) \\ \text { TOTAL } & 1016(524-1578)\end{array}$

\begin{tabular}{|c|}
\hline SUGGESTED GRAZING CAPACITY \\
1.8 HA/AUM \\
\end{tabular}




\section{F12: Sw-Aw/Scouring rush \\ (Picea glauca-Populus tremuloides/Equisetum scirpoides)}

$\mathbf{n = 1}$ This community occupies moist, nutrient rich, lower slope positions. This community is very similar to the Sw/Horsetail community described by Archibald et al. (1996). Archibald et al. felt that the ecosite representing this community represented the wettest and most nutrient rich conditions for the Montane subregion. They felt balsam poplar was the pioneer species on this ecosite and that succession would be to white spruce. The high tree cover limits the light reaching the forest floor. Consequently, there is little forage available for domestic livestock. This community should be rated as non-use.

\section{Plant COMPOSITION CANOPY COVER (\%)} MEAN RANGE CONST.

\section{TREeS}

ASPEN

(Populus tremuloides)

WHITE SPRUCE

(Picea glauca)

BALSAM POPLAR

(Populus balsamifera)

15

100

SHRUBS

ROSE

(Rosa acicularis)

$$
3
$$

\section{FORBS}

DANDELION

(Taraxacum officinale)

DWARF SCOURING RUSH

(Equisetum scirpoides) $20 \quad$ - $\quad 100$

LINDLEY'S ASTER

(Aster ciliolatus)

AMERICAN VETCH

(Vicia americana)

\section{GRASSES}

KENTUCKY BLUEGRASS

$$
\text { (Poa pratensis) }
$$

HAIRY WILD RYE

(Elymus innovatus)

$4 \quad-\quad 100$

100

\section{ENVIRONMENTAL VARIABLES}

MOISTURE REGIME: SUBHYGRIC

NUTRIENT REGIME: PERMESOTROPHIC

ELEVATION: 1494 M

SLOPE: $1 \%$

\section{ASPECT: SOUTHEAST}

SOIL DRAINAGE: MODERATELY WELL

\section{FORAGE PRODUCTION (KG/HA)}

TOTAL $\quad 800 \mathrm{KG} / \mathrm{HA} *$

$\left({ }^{*}\right.$ EsTIMATED $)$

\section{SUGGESTED GRAZING CAPACITY}

NON-USE 


\section{DECIDUOUS COMMUNITY TYPES}

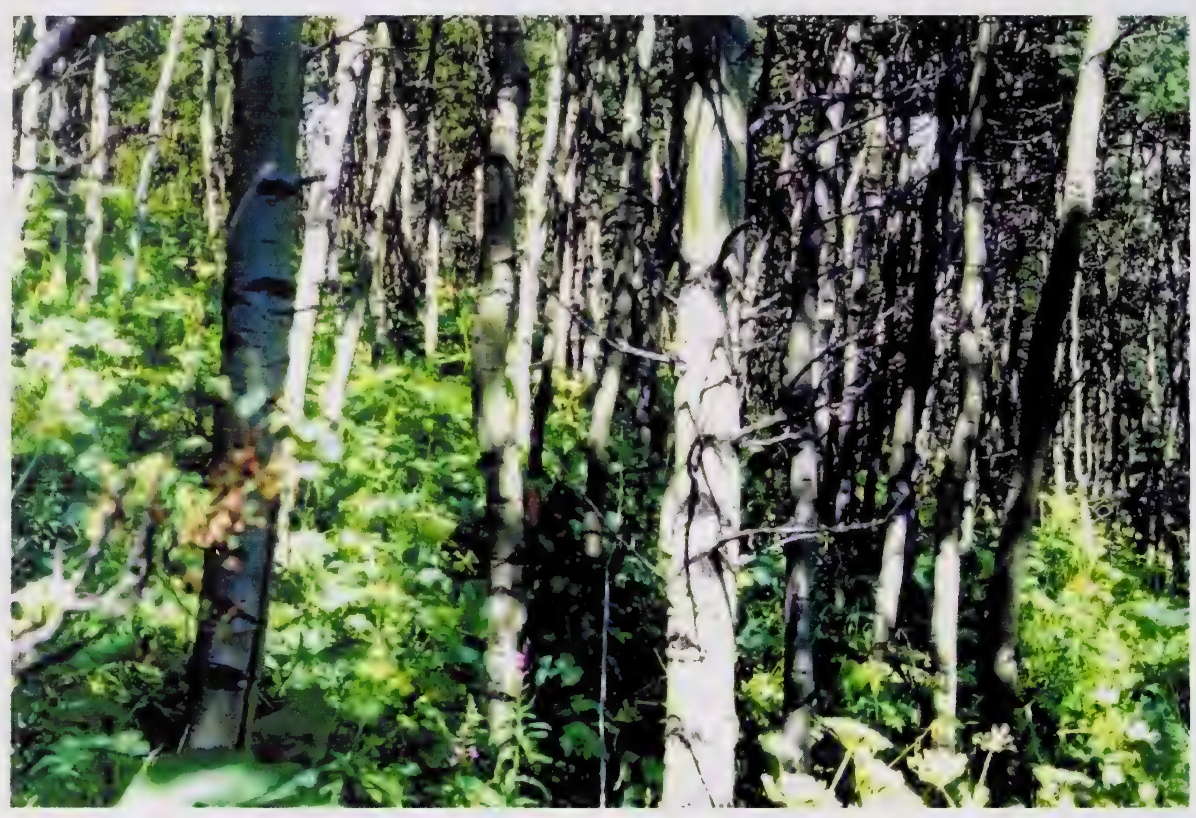

Photo 10: This Aw/Cow parsnip community type is typical of moist, nutrient-rich seepage areas north of the Crowsnest Pass. South of the pass cow parsnip is often replaced by thimbleberry. 


\section{Key to Deciduous community types}

1. Site is wet with Balsam poplar dominating the overstory

Drier sites with Aspen dominating the overstory.

2. Marsh reedgrass dominates the understory. Site is in the lower slope position where it receives some nutrient rich seepage during the growing season. Community type is generally found north of the Porcupine Hills on North or Easterly aspects

Aw-Pb/Marsh reedgrass $\mathrm{g} 9 \mathrm{a}$

Richer sites with more moisture dominated by Thimbleberry, Cow parsnip, or Snowberry in the understory. Sites also found at lower slope positions and receive nutrient seepage at some point in the year. 3 3. Site is moist as indicated by Thimbleberry in the understory and Balsam poplar dominating the overstory. Community type described at higher subalpine elevations near Waterton Lakes Park.

Cow parsnip, or Snowberry dominates the understory

$\mathrm{Pb} /$ Thimbleberry $\frac{\mathrm{g} 12}{4}$

4. Site is similar to $\mathrm{Pb}$ /Timothy but subhygric with Cow parsnip dominating the understory and was described North of the Crowsnest pass ..Pb/Cow parsnip/Kentucky bluegrass

Snowberry dominates the understorey. $\mathrm{Pb} /$ Snowberry/K. bluegrass $\frac{\mathrm{g} 13}{\mathrm{~g} 14}$

5. Dry sites found on upper slope positions and hilltops dominated by Bearberry and Rough fescue

Mesic to wet sites.

Aw/Bearberry/Rough fescue $\mathrm{gl}$

6. Mesic sites dominated by White meadowsweet, Pinegrass, Hairy wildrye, or Snowberry and includes grazed sites with

Kentucky bluegrass, timothy and dandelion.............................................................................................................. 7

Wet sites and moist seeps, Willow, Birch, Thimbleberry, Cow parsnip dominated .................................................. 15

7. Grazed sites dominated by Kentucky bluegrass, Timothy and Dandelion.

Ungrazed sites where White meadowsweet, Pinegrass, Hairy wildrye, Snowberry, Rose, Saskatoon, dominate the understory

8. Snowberry and Kentucky bluegrass dominated. A heavily grazed site that has been rested enough that some native species have recovered.

Timothy or Pinegrass dominant with Kentucky bluegrass

Aw/Snowberry/Kentucky bluegrass

$\frac{\mathrm{g} 9}{9}$

9. Timothy and Kentucky bluegrass dominated. Site has been heavily grazed recently, and not rested enough to allow the reestablishment of native vegetation

Aw/Timothy-Kentucky bluegrass $\mathrm{g} 7$

Pinegrass and Kentucky bluegrass dominated. Site had been grazed heavily and rested resulting in re-establishment of some native species.

10. Drier sites with poorer nutrient regimes(hairy wildrye dominates understory)

Aw/Pinegrass-Kentucky bluegrass g6

Wetter more nutrient rich sites

11

11. Site is found in the Ya Ha Tinda area and has insignificant or no shrub layer. Hairy wildrye is the dominant grass...

Site has a shrub layer of Rose.

Aw/Hairy wildrye g3

12. Site is rich with Snowberry and/or Saskatoon as the dominant shrubs....

Aw/Rose/Hairy wildrye $\frac{\mathrm{g} 2}{13}$

Site is not so rich and is dominated by White meadowsweet and Pinegrass.

13. Snowberry is dominant.

Saskatoon and Snowberry are dominant.

14. Site contains White meadowsweet

Site dominated by Pinegrass, no White meadowsweet Aw/Snowberry-Saskatoon

Aw/White meadowsweet/Pinegrass Aw/Rose/Pinegrass g 5

15. Site found in a riparian zone

Aw/Birch-Willow g15

Site is a nutrient rich seep at some point in the year, not in riparian zone.

Aw/Thimbleberry g 10

Nutrient rich seepage area north of the Crowsnest Pass Aw/Cow parsnip gll 


\section{G1: Aw/Bearberry/Rough fescue \\ (Populus tremuloides/Arctostaphylos uva-ursi/Festuca scabrella)}

$\mathbf{n}=\mathbf{8}$ This community type occupies dry, upper slope and hilltop positions and represents the invasion of aspen onto a Rough fescue-Sedge/Bearberry-dominated community type. The soils on this community type are fairly well developed and the moisture conditions are high enough to favour the growth of aspen. In years of drought aspen will likely die back in this community type. Frequent fire also tends to ccntrol the spread of aspen onto these rough fescue dominated grasslands. The lack of fire in the last 50 years has allowed many of these grasslands to be invaded by aspen. Invasion of aspen causes a $50 \%$ decline in forage productivity and a loss in soil productivity.

\section{PLANT COMPOSITION CANOPY COVER (\%)} MEAN RANGE CONST.

\section{TREES}

ASPEN

(Populus tremuloides)

$$
50
$$$$
30-75 \quad 100
$$

SHRUBS

SHRUBBY CINQUEFOIL

(Potentilla fruticosa)

ROSE

(Rosa acicularis)

SNOWBERRY

(Symphoricarpos albus)

$1 \quad 0-6 \quad 38$

$3 \quad 0-15 \quad 50$

$2 \quad 0-9 \quad 25$

\section{FORBS}

BEARBERRY

(Arctostaphylos uva-ursi) $19 \quad 1-37 \quad 100$

LINDLEY'S ASTER

(Aster ciliolatus)

STRAWBERRY

(Fragaria virginiana) 8

STICKY PURPLE GERANIUM

(Geranium viscosissimum)5

\section{GRASSES}

ROUGH FESCUE

(Festuca scabrella) $\quad 9 \quad 0-15 \quad 75$

PINEGRASS

(Calamagrostis rubescens) $20 \quad 0-57 \quad 88$

IDAHO FESCUE

(Festuca idahoensis) $3 \quad 0-12 \quad 50$

HAIRY WILDRYE

(Elymus innovatus) $\quad 5 \quad 0-19 \quad 75$

\section{ENVIRONMENTAL VARIABLES}

MoISTURE REGIME: SUBMESIC

NUTRIENT REGIME: MESOTROPHIC

ELEVATION: 1495(1420-1570) M

SOIL DRAINAGE: WELL

SLOPE: $7(0-15) \%$

ASPECT: SOUTH

\section{FORAGE PRODUCTION (KG/HA)}

GRASS 578(318-1070)

FORB 220(0-462)

SHRUB 148(14-318)

TOTAL 946(436-1528) 


\section{G2: Aw/Rose/Hairy wildrye \\ (Populus tremuloides/Rosa acicularis/Elymus innovatus)}

$\mathbf{n = 5}$ This community type occurs on submesic, well drained, south and west-facing slopes. It is situated in slightly lower slope positions and therefore has better developed soils than the limber pine and bearberry-dominated community types previously described. Archibald et al. (1996) described this community type as being part of the Canada buffaloberry-hairy wildrye ecosite. They felt this ecosite to be relatively dry for the subregion, but not as dry as the limber pine and bearberry ecosites. Succession on this site will likely be to the P1/Buffaloberry/Pinegrass or Fd/Hairy wildrye-dominated community types previously described. This community type has a moderate amount of forage for domestic livestock. It should be rated as secondary range.

\section{PLANT COMPOSITION CANOPY COVER (\%)} MEAN RANGE CONST.

TREES

ASPEN

(Populus tremuloides)

62

$36-75 \quad 100$

SHRUBS

ROSE

(Rosa acicularis)

SHRUBBY CINQUEFOIL

(Potentilla fruticosa)

SNOWBERRY

(Symphoricarpos

occidentalis)

$\begin{array}{lll}14 & 4-40 & 100 \\ 1 & 0-1 & 40 \\ 2 & 0-3 & 60\end{array}$

\section{ENVIRONMENTAL VARIABLES}

MOISTURE REGIME: MESIC

NUTRIENT REGIME: MESOTROPHIC

ELEVATION :1589 (1350-2270) M

SLOPE: $4(0-10) \%$

ASPECT: SOUTHERLY

SOIL DRAINAGE: WELL TO RAPIDLY

FORAGE PRODUCTION (KG/HA)

\section{FORBS}

LINDLEY'S ASTER

(Aster ciliolatus)

WILD STRAWBERRY

(Fragaria virginiana) $\quad 12 \quad 3-29 \quad 100$

DANDELION

$\begin{array}{llll}\text { (Taraxacum officinale) } & 4 & 1-8 & 100\end{array}$

YELLOW PEAVINE

(Lathyrus ochroleucus) $\quad 4 \quad 1-8 \quad 100$

FIREWEED

(Epilobium angustifolium)2 $\quad 0-8 \quad 60$

\section{GRASSES}

HAIRY WILD RYE

(Elymus innovatus) $\quad 25 \quad 16-37 \quad 100$

ROUGH FESCUE

$\begin{array}{llll}\text { (Festuca scabrella) } & 2 & 0-4 & 60\end{array}$

PINEGRASS

(Calamagrostis rubescens) 4

$0-12 \quad 60$

GRASS $856(374-1906)$

FORB 313(222-408)

SHRUB 75(0-252)

TOTAL 1244(652-2330)

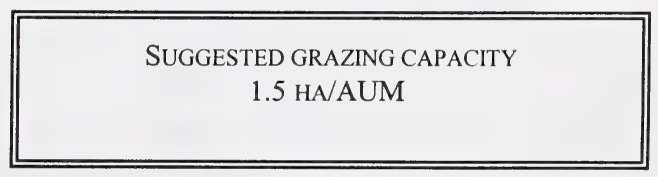




\section{G3: Aw/Hairy wildrye \\ (Populus tremuloides/Elymus innovatus)}

$\mathbf{n}=\mathbf{1}$ This community type occurs on submesic, well drained, south and west-facing slopes within the Ya Ha Tinda area. It occurs in areas of the grasslands where moisture is sufficient to grow trees. Beckingham et al. (1996) described this community type as being part of the hairy wildrye ecosite. They felt this ecosite to be relatively dry for the subregion, but not as dry as the bearberry and grassland ecosites. Succession on this site will likely be to the $\mathrm{Pl} / \mathrm{Hairy}$ wildrye or Sw/Hairy wildrye-dominated community types previously described. This community type has a high amount of forage because of the increased moisture. In the winter elk often occupy these sites as bedding areas during the day. The southerly and westerly aspect increases solar gains and the trees provide a degree of security.

\section{PLANT COMPOSITION CANOPY COVER (\%)}

MEAN RANGE CONST.

\section{TREES}

ASPEN

(Populus tremuloides)

35

100

\section{SHRUBS}

SHRUBBY CINQUEFOIL

(Potentilla fruticosa)

FORBS

AMERICAN VETCH

(Vicia americana)

WILD STRAWBERRY

(Fragaria virginiana)

YARROW

(Achillea millefolium)

YELLOW PEAVINE

(Lathyrus ochroleucus)

NORTHERN BEDSTRAW

(Galium boreale)

\section{GRASSES}

HAIRY WILD RYE

(Elymus innovatus)

ROUGH FESCUE

(Festuca scabrella)

TIMOTHY

(Phleum pratense)

FRINGED BROME

(Bromus ciliatus)

100

100

\section{ENVIRONMENTAL VARIABLES}

MOISTURE REGIME :

SUBMESIC

NUTRIENT REGIME:

MESOTROPHIC

ELEVATION:

$1700 \mathrm{M}$

SLOPE:

$$
10 \%
$$

ASPECT:

SOUTHERLY

SOIL DRAINAGE:

WELL

FORAGE PRODUCTION (KG/HA)

GRASS 836

FORB 1228

TOTAL 2064

SUGGESTED GRAZING CAPACITY(HORSES)

$1.3 \mathrm{HA} / \mathrm{AUM}$ 


\section{G4: Aw/White meadowsweet/Pinegrass \\ (Populus tremuloides/Spiraea betulifolia/Calamagrostis rubescens)}

$\mathbf{n}=12$ This community is one of several community types which represent the mesic/medium ecosite for the Montane subregion. These sites can be dominated by Douglas fir, white spruce, aspen or lodgepole pine. The understory can be dominated by white meadowsweet, pinegrass or feather moss depending upon the successional status of the stand. In the vicinity of the Crowsnest Pass creeping mahonia is also common on these sites (Archibald et al. 1996). White meadowsweet is well adapted to growing on dry rocky slopes (MacKinnon et al. 1992). The presence of a high cover of white meadowsweet may indicate slightly drier conditions and shallower soils than a community dominated by pinegrass. Because this community type is in an early successional stage it produces a moderate amount of forage for domestic livestock and should be considered secondary range.

\section{Plant COMPOSITION CANOPY COVER (\%)} MEAN RANGE CONST.

\section{TREES}

ASPEN

(Populus tremuloides)

LODGEPOLE PINE

(Pinus contorta)

SHRUBS

WHITE MEADOWSWEET

(Spiraea betulifolia)

ROSE

(Rosa acicularis.)

DWARF BILBERRY

(Vaccinium caespitosum)

SHRUBBY CINQUEFOIL

(Potentilla fruticosa)

CANADA BUFFALOBERRY

(Shepherdia canadensis) T

FORBS

SHOWY ASTER

(Aster conspicuus)

STRAWBERRY

(Fragaria virginiana)

NORTHERN BEDSTRAW

(Galium boreale)

YELLOW PEAVINE

(Lathyrus ochroleucus)

49

$30-74 \quad 100$

3

$0-15$

42

$17 \quad 10-29 \quad 100$

$\begin{array}{lll}3 & 0-7 & 92\end{array}$

$2 \quad 0-14 \quad 25$

$1 \quad 0-2 \quad 25$

$0-2 \quad 33$

$1-23 \quad 100$

1-15 100

$1-3 \quad 100$

$0-14 \quad 92$

GRASSES

HAIRY WILD RYE

(Elymus innovatus)

SEDGE

(Carex spp.)

PINEGRASS

(Calamagrostis rubescens)23 8-51 100

\section{ENVIRONMENTAL VARIABLES}

MoISTURE REGIME: MesiC TO SUBHYGRIC

NUTRIENT REGIME: MESOTROPHIC TO PERMESOTROPHIC

ELEVATION RANGE (MEAN): 1543(1460-1676) M

ASPECT: SOUTH TO WeST

SLOPE: $9(0-25) \%$

SOIL DRAINAGE: WELL TO MOD. WELL

FORAGE PRODUCTION (KG/HA)

GRASS 882(332-2102)

FORB 470(404-976)

SHRUB 75(0-216)

TOTAL $1410(852-2834)$

SUGGESTED GRAZING CAPACITY

$1.3 \mathrm{HA} / \mathrm{AUM}$ 


\section{G5: Aw/Rose/Pinegrass \\ (Populus tremuloides/Rosa acicularis/Calamagrostis rubescens)}

$\mathbf{n}=35$ This community, dominated by a aspen overstory and an understory of pinegrass, and represents an earlier successional stage of the $\mathrm{P} /$ Pinegrass community type. This community is also very similar to the previously described Aw/White meadowsweet/Pinegrass community type, but the high cover of pinegrass and low cover of white meadowsweet may indicate slightly moister, better developed soils. Pinegrass is generally unpalatable to livestock, but if it is grazed early in the spring they will utilize it as a forage source. The forage productivity of this community type is moderate. As a result, this community should be rated as secondary range.

Plant Composition CANopy Cover (\%) MEAN RANGE CONST.

\section{TREES}

BALSAM POPLAR

(Populus balsamifera) $\quad 2 \quad 0-35 \quad 14$

ASPEN

(Populus tremuloides) $\quad 47 \quad 3-70 \quad 100$

SHRUBS

ROSE

(Rosa acicularis)

WHITE MEADOWSWEET

(Spiraea betulifolia) $\quad 1 \quad 0-12 \quad 35$

SASKATOON

$\begin{array}{llll}\text { (Amelanchier alnifolia) } \quad 1 & 0-2 & 53\end{array}$

\section{FORBS}

YELLOW PEAVINE

(Lathyrus ochroleucus) $\quad 5 \quad 0-11$

NORTHERN BEDSTRAW

(Galium boreale)

STRAWBERRY

(Fragaria virginiana) $\quad 9 \quad 0-20 \quad 97$

AMERICAN VETCH

(Vicia americana)

LINDLEY'S ASTER

(Aster ciliolatus)

SHOWY ASTER

(Aster conspicuus)

GRASSES

PINEGRASS

(Calamagrostis rubescens) $18 \quad 0-51 \quad 94$

HAIRY WILDRYE

(Elymus innovatus)

$\begin{array}{lll}6 & 0-23 \quad 82\end{array}$

\section{ENVIRONMENTAL VARIABLES}

MOISTURE REGIME : SUBMESIC TO MESIC

NUTRIENT REGIME: MESOTROPHIC TO PERMESOTROPHIC

ELEVATION RANGE: 1532(1360-1710)

ASPECT: SOUTHERLY

SOIL DRAINAGE: WELL

SLOPE: $11(0-15) \%$

\section{FORAGE PRODUCTION(KG/HA)}

\author{
GRASS $786(0-3318)$ \\ FORB 532(0-1584) \\ SHRUB $91(0-378)$ \\ TOTAL $1408(538-2204)$
}

\section{SUGGESTED GRAZING CAPACITY}

$1.3 \mathrm{HA} / \mathrm{AUM}$ 


\section{G6: Aw/Pinegrass-Kentucky bluegrass \\ (Populus tremuloides/Calamagrostis rubescens-Poa pratensis)}

$\mathbf{n}=4$ This community type is very similar to the previously described Aw/Rose/Pinegrass community, but has been grazed by livestock. It appears that this community type was grazed heavily in the past and then rested. Willoughby (1995) found that aspen stands that have been heavily grazed for prolonged periods have a low cover of native shrubs, forbs and grass species and a high cover of Kentucky bluegrass, clover and dandelion. This community has a high cover of Kentucky bluegrass, but it also has a high cover of native shrubs, forbs and grass, which may indicate that it has been grazed heavily to the point of Kentucky bluegrass invasion and then rested allowing recovery of the native species. This community is very productive for domestic livestock, but Kentucky bluegrass provides a poor source of forage for wintering wildlife.

\section{PLANT COMPOSITION CANOPY COVER (\%)} MEAN RANGE CONST.

\section{TREES}

ASPEN

(Populus tremuloides)

29

$15-40 \quad 100$

\section{SHRUBS}

WILD RED RASPBERRY

(Rubus idaeus)

ROSE

(Rosa acicularis)

$\begin{array}{lll}7 & 1-9 & 100 \\ 7 & 1-14 & 100\end{array}$

FORBS

STRAWBERRY

(Fragaria virginiana) $\quad 5 \quad 1-10 \quad 100$

SMOOTH ASTER

(Aster laevis)

DANDELION

(Taraxacum officinale)

WILD WHITE GERANIUM

(Geranium richardsonii) $8 \quad 1-19 \quad 100$

YELLOW PEAVINE

$\begin{array}{llll}\text { (Lathyrus ochroleucus) } & 4 & 1-7 & 100\end{array}$

\section{GraSSES}

\section{PINEGRASS}

(Calamagrostis rubescens) $13 \quad 2-28 \quad 100$

HAIRY WILDRYE

(Elymus innovatus) $\quad 2 \quad 0-5 \quad 75$

KENTUCKY BLUEGRASS

(Poa pratensis)

\section{ENVIRONMENTAL VARIABLES}

MOISTURE REGIME: MESIC

NUTRIENT REGIME: MESOTROPHIC

ELEVATION: 1463(1432-1493) M

ASPECT: SOUTHERLY

SLOPE: $13(5-20) \%$

SOIL DRAINAGE: WELL

\section{FORAGE PRODUCTION(KG/HA)}

GRASS 1005(0-2402)

FORB 582(194-884)

SHRUB 126(0-236)

TOTAL 1713(770-3286)

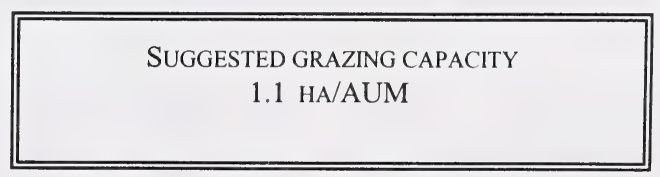




\section{G7: Aw/Timothy-Kentucky bluegrass \\ (Populus tremuloides/Phleum pratense-Poa pratensis)}

$\mathbf{n}=13$ This community is similar to the Aw/Rose/Pinegrass community, but heavy grazing pressure has shifted the understory away from native species and allowed dandelion, clover, timothy and Kentucky bluegrass to establish on the site. This change in species composition with increased grazing pressure is similar to work done by Willoughby (1995). The invasion of non-native species onto this site makes this community very productive for domestic livestock, but the presence of overgrazed communities indicates some type of distribution problem and the management of the disposition should be discussed with the permittees.

\section{PLANT COMPOSITION CANOPY COVER (\%) \\ MEAN RANGE CONST.}

TREES

ASPEN

(Populus tremuloides) 65

\section{SHRUBS}

SASKATOON

(Amelanchier alnifolia) $\quad 6 \quad 0-20 \quad 76$

SNOWBERRY

(Symphoricarpos

occidentalis)

RosE

(Rosa acicularis)

FORBS

DANDELION

(Taraxacum officinale)

WILD BERGAMONT

(Monarda fistulosa)

STRAWBERRY

(Fragaria virginiana)

WILD WHITE GERANIUM

(Geranium richardsonii)

Clover

(Trifolium hybridum)

$4 \quad 0-9 \quad 75$

$\begin{array}{lll}7 & 0-20 \quad 69\end{array}$

$\begin{array}{lll}6 & 0-39 \quad 85\end{array}$

$1 \quad 0-11 \quad 31$

$4 \quad 0-10 \quad 92$

$2 \quad 0-11 \quad 69$

$2 \quad 0-20 \quad 23$

GRASSES

TIMOTHY

(Phleum pratense)

KENTUCKY BLUEGRASS

(Poa pratensis)

SMOOTH BROME

(Bromus inermis)
$13 \quad 1-41 \quad 100$

$5 \quad 0-26 \quad 55$

$2 \quad 0-14 \quad 39$

\section{ENVIRONMENTAL VARIABLES}

MOISTURE REGIME: MESIC

NUTRIENT REGIME: MESOTROPHIC

ELEVATION: 1395(1250-1536)M

ASPECT: SOUTHERLY

SLOPE: $8(0-20) \%$

SOIL DRAINAGE: WELL

\section{FORAGE PRODUCTION (KG/HA)}

GRASS 1006(794-1242)

FORB 114(0-176)

SHRUB 242(0-854)

TOTAL 1362(1034-1824)

SUGGESTED GRAZING CAPACITY

$1.3 \mathrm{HA} / \mathrm{AUM}$ 


\section{G8: Aw/Snowberry-Saskatoon}

(Populus tremuloides/Symphoricarpos occidentalis(S.albus)-Amelanchier alnifolia)

$\mathbf{n = 1 1}$ This community is one of several community types which represent the mesic/rich ecosite for the Montane subregion (Archibald et al. 1996). These sites can be dominated by white spruce, aspen or lodgepole pine. The understory can be dominated by thimbleberry, snowberry, saskatoon or pinegrass. Succession of this community type will likely be to white spruce. The Aw/Thimbleberry dominated community type is probably moister and slightly richer than this community type. Forage production on the aspen phase of this ecosite can be quite high averaging $1278 \mathrm{~kg} / \mathrm{ha}$. This makes these community types moderately productive for domestic livestock and should be rated as secondary range.

\section{PLANT COMPOSITION CANOPY COVER (\%)} MEAN RANGE CONST.

\section{TREES}

ASPEN

(Populus tremuloides) $\quad 66 \quad 45-99 \quad 100$

\section{SHRUBS}

SASKATOON

$\begin{array}{llll}\text { (Amelanchier alnifolia) } & 13 & 0-28 \quad 82\end{array}$

SNOWBERRY

(Symphoricarpos

occidentalis, S. albus) $\quad 32 \quad 2-97 \quad 100$

WHITE MEADOWSWEET

(Spiraea betulifolia) $\quad 4 \quad 0-19 \quad 36$

ROSE

(Rosa acicularis)

FORBS

STRAWBERRY

(Fragaria virginiana) $5 \quad 1-15$

LINDLEY'S ASTER

(Aster ciliolatus)

YELLOW PEAVINE

(Lathyrus ochroleucus) $\quad 3 \quad 0-8 \quad 82$

SHOWY ASTER

(Aster conspicuus)

CANADA VIOLET

(Viola canadensis)

COW PARSNIP

(Heracleum lanatum) $\quad 6 \quad 0-10 \quad 45$

GRASSES

HAIRY WILD RYE

(Elymus innovatus)

PINEGRASS

(Calamagrostis rubescens) $3 \quad 0-14 \quad 73$

KENTUCKY BLUEGRASS

(Poa pratensis)

\section{ENVIRONMENTAL VARIABLES}

MOISTURE REGIME: MESIC-SUBHYGRIC

NutRIENT REGIME: MESOTROPHIC To

PERMESOTROPHIC

ELEVATION RANGE : $1486(1370-1680)$ M

ASPECT: SOUTH TO EAST

SLOPE: $21(0-35) \%$

SOIL DRAINAGE: WELL TO MOD. WELL

\section{FORAGE PRODUCTION (KG/HA)}

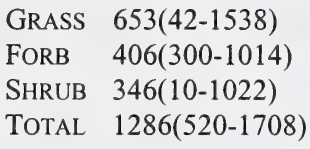

SUGGESTED GRAZING CAPACITY

$1.4 \mathrm{HA} / \mathrm{AUM}$

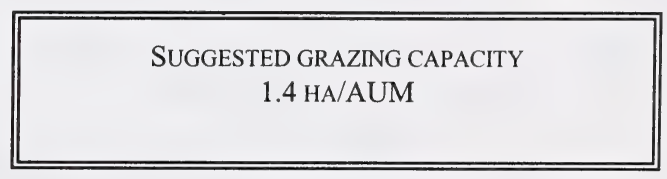




\section{G9: Aw/Snowberry/Kentucky bluegrass \\ (Populus tremuloides/Symphoricarpos albus/Poa pratensis)}

$\mathbf{n}=\mathbf{2}$ This community type is very similar to the previously described Aw/Snowberry-Saskatoon community, but has been grazed by livestock. It appears that this community type was grazed heavily in the past and then rested. Willoughby (1995) found that aspen stands that have been heavily grazed for prolonged periods have a low cover of native shrubs, forbs and grass species and a high cover of Kentucky bluegrass, clover and dandelion. This community has a high cover of Kentucky bluegrass, but it also has a high cover of native shrubs, forbs and grass, which may indicate that it has been grazed heavily to the point of Kentucky bluegrass invasion and then rested allowing recovery of the native species. This community is very productive for domestic livestock, but Kentucky bluegrass provides a poor source of forage for wintering wildlife.

\section{Plant COMPOSITION CANOPY COVER (\%)} MEAN RANGE CONST.

TREES

\section{ASPEN}

\section{(Populus tremuloides)}

WHITE SPRUCE

(Picea glauca)

\section{SHRUBS}

ROSE

(Rosa acicularis)

RED TWINBERRY

(Lonicera utahensis)

SASKATOON

(Amelanchier alnifolia)

SNOWBERRY

(Symphoricarpos albus)

FORBS

CREEPING MAHONIA

(Berberis repens)

DANDELION

(Taraxacum officinale)

YELLOW PEAVINE

(Lathyrus ochroleucus)

STRAWBERRY

(Fragaria virginiana)

VEINY MEADOW RUE

(Thalictrum venulosum)

GRASSES

KENTUCKY BLUEGRASS

(Poa pratensis)

MOUNTAIN BROME

(Bromus carinatus)

ONION GRASS

(Melica spectabilis)

$\begin{array}{lll}64 & 50-78 & 100 \\ 3 & 2-3 & 100\end{array}$

$\begin{array}{lll}6 \quad 3-7 & 100\end{array}$

$2 \quad 0-4 \quad 50$

$1 \quad 0-2 \quad 50$

$21 \quad 16-24 \quad 100$

$12 \quad 7-17 \quad 100$

$\begin{array}{lll}7 & 1-12 \quad 100\end{array}$

$2 \quad 1-3 \quad 100$

$2 \quad 1-2 \quad 100$

$\begin{array}{lll}4 & 0-7 & 50\end{array}$

$24 \quad 17-34 \quad 100$

$8 \quad 0-16 \quad 50$

$5 \quad 0-9 \quad 50$

\section{ENVIRONMENTAL VARIABLES}

MOISTURE REGIME: MesiC

NUTRIENT REGIME: MESOTROPHIC

SOIL DRAINAGE: WELL TO RAPIDLY

ELEVATION: 1414(1372-1457)M

ASPECT: SOUTHERLY

SLOPE: $\quad 3(2-4) \%$

\section{FORAGE PRODUCTION(KG/HA)}

$$
\begin{array}{ll}
\text { GRASS } & 606(516-696) \\
\text { FORB } & 749(734-764) \\
\text { SHRUB } & 354(0-708)) \\
\text { TOTAL } & 1709(1460-1958)
\end{array}
$$

SUGGESTED GRAZING CAPACITY

$$
\text { 1.1 HA/AUM }
$$




\section{G9a: Aw-Pb/Marsh reedgrass \\ (Populus tremuloides-P.balsamifera/Calamagrostis canadensis)}

$\mathbf{n}=\mathbf{8}$ This community type was described on lower slope positions where some nutrient rich seepage occurs during the growing season. It is generally found north of the Porcupine Hills in areas that have north and easterly aspects. Marsh reedgrass is not common in the Montane subregion and the presence of this grass species may indicate that the climate is closer to the Lower Foothills or Subalpine subregion. This community type has a low shrub cover and extensive cover of grass which makes it fairly attractive to livestock. Often these community types are heavily utilized.

\section{PLANT COMPOSITION CANOPY COVER (\%)} MEAN RANGE CONST.

TREES

ASPEN

(Populus tremuloides) $\quad 43 \quad 20-60 \quad 100$

BALSAM POPLAR

(Populus balsamifera) $\quad 9 \quad 0-25 \quad 38$

SHRUBS

ROSE

(Rosa acicularis)

SASKATOON

(Amelanchier alnifolia)

$1 \quad 0-2 \quad 63$

$2 \quad 0-15 \quad 13$

FORBS

\section{FIREWEED}

(Epilobium angustifolium)7 $\quad 1-14 \quad 100$

DANDELION

$\begin{array}{llll}\text { (Taraxacum officinale) } & 5 & 1-9 & 100\end{array}$

YELLOW PEAVINE

(Lathyrus ochroleucus) $\quad 4 \quad 0-10 \quad 63$

STRAWBERRY

$\begin{array}{llll}\text { (Fragaria virginiana }) & 4 & 1-8 & 100\end{array}$

VEINY MEADOW RUE

(Thalictrum venulosum) $\quad 6 \quad 0-18 \quad 63$

WILD WHITE GERANIUM

$\begin{array}{llll}\text { (Geranium richardsonii) } & 12 & 0-27 & 88\end{array}$

GRASSES

KENTUCKY BLUEGRASS

(Poa pratensis) $\quad 3 \quad 0-16 \quad 63$

MARSH REEDGRASS

(Calamagrostis canadensis)20 $\quad 10-38 \quad 100$

FRINGED BROME

(Bromus cilatus)

$3 \quad 0-7 \quad 75$

\section{ENVIRONMENTAL VARIABLES}

MOISTURE REGIME: MESIC

NUTRIENT REGIME: PERMESOTROPHIC

SOIL DRAINAGE: WeLL

ELEVATION: 1494(1417-1570)M

ASPECT: NORTHERLY, EASTERLY

SLOPE: $\quad 4(0-10) \%$

\section{FORAGE PRODUCTION(KG/HA)}

GRASS 1042(0-2568)

FORB 404(186-498)

SHRUB 39(0-144)

TOTAL 1485(960-2568)

SUGGESTED GRAZING CAPACITY

$1.2 \mathrm{HA} / \mathrm{AUM}$

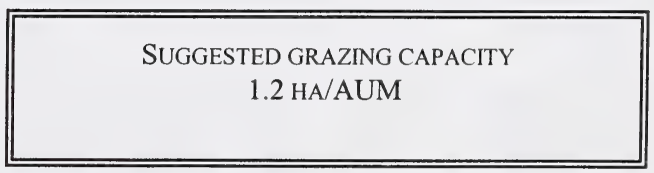




\section{G10: Aw/Thimbleberry \\ (Populus tremuloides/Rubus parviflorus)}

$\mathbf{n}=\mathbf{8}$ Nutrient rich seepage occurs at some point in the growing season in this community type favouring the growth of thimbleberry. On these sites thimbleberry is very common south of the Crowsnest Pass and is generally replaced by cow parsnip north of the Pass. Succession on these sites will be from aspen to pine and then to white spruce. Forage productivity on these sites is generally quite high because of the favourable moisture and nutrient conditions. Thimbleberry is generally unpalatable to livestock, but if the site has an abundance of cow parsnip it may be extensively utilized. This community type should be rated as secondary range.

\section{PLANT COMPOSITION CANOPY COVER (\%)}

\section{TREES}

WHITE SPRUCE

(Picea glauca)

ASPEN

(Populus tremuloides) $\quad 70 \quad 30-90 \quad 100$

BALSAM POPLAR

(Populus balsamifera) $\quad 3 \quad 0-21 \quad 25$

SHRUBS

WHITE MEADOWSWEET

(Spiraea betulifolia)

THIMBLEBERRY

(Rubus parviflorus)

SNOWBERRY

(Symphoricarpos

occidentalis)

SASKATOON

(Amelanchier alnifolia)

FORBS

WILD STRAWBERRY

(Fragaria virginiana) $\quad 4 \quad 0-11 \quad 88$

SHOWY ASTER

(Aster conspicuus)

COW PARSNIP

(Heracleum lanatum) $\quad 4 \quad 0-24 \quad 38$

VEINY MEADOW RUE

(Thalictrum venulosum) $5 \quad 0-13 \quad 75$

NORTHERN BEDSTRAW

(Galium boreale)

WILD WHITE GERANIUM

(Geranium richardsonii)

GRASSES

HAIRY WILDRYE

(Elymus innovatus)

PINE GRASS

(Calamagrostis rubescens) 4

KENTUCKY BLUEGRASS

$0-10 \quad 88$
(Poa pratensis)

1

$0-15$

50

\section{ENVIRONMENTAL VARIABLES}

MOISTURE REGIME: SUBHYGRIC TO MESIC

NUTRIENT REGIME : PERMESOTROPHIC

ELEVATION: 1633(1562-1707)M

ASPECT: SOUTHERLY

SLOPE: $15(5-20) \%$

SOIL DRAINAGE: WELL

\section{FORAGE PRODUCTION (KG/HA)}

GRASS $575(232-1194)$

FORB 454(300-658)

SHRUB 380(172-584)

TOTAL 1410(1108-1878)

SUGGESTED GRAZING CAPACITY 1.3HA/AUM

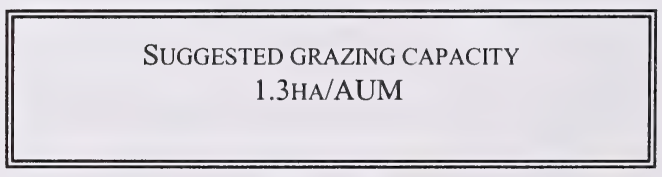




\section{G11: Aw/Cow parsnip \\ (Populus tremuloides/Heracleum lanatum)}

$\mathbf{n}=6$ Nutrient rich seepage occurs at some point in the growing season favouring the growth of cow parsnip. This community type is very similar to the Aw/Thimbleberry community, but is more common north of the Crowsnest Pass. Forage productivity on these sites is generally quite high because of the favourable moisture and nutrient conditions. Cow parsnip is palatable to livestock and maybe extensively utilized. This community type should be rated as secondary range.

PLANT COMPOSITION CANOPY COVER (\%) MEAN RANGE CONST.

TREES

ASPEN

(Populus tremuloides) $\quad 58 \quad 25-90 \quad 100$

SHRUBS

ROSE

(Rosa acicularis) $\quad 2 \quad 0-6 \quad 71$

WHITE MEADOWSWEET

(Spiraea betulifolia) $4 \quad 0-15 \quad 57$

\section{FORBS}

COW PARSNIP

(Heracleum lanatum) $\quad 30 \quad 3-65 \quad 100$

VEINY MEADOW RUE

(Thalictrum venulosum) $\quad 7 \quad 0-17 \quad 86$

SHOWY ASTER

(Aster conspicuus) $\quad 6 \quad 0-12 \quad 86$

STRAWBERRY

$\begin{array}{llll}\text { (Fragaria virginiana) } & 3 & 0-6 & 86\end{array}$

FIREWEED

(Epilobium angustifolium) $7 \quad 1-32 \quad 86$

\section{GrasseS}

PINEGRASS

(Calamagrostis rubescens)6 9-19 57

SMOOTH WILDRYE

(Elymus glaucus)

$3 \quad 0-7 \quad 57$

\section{ENVIRONMENTAL VARIABLES}

MOISTURE REGIME: SUBHYGRIC TO MESIC

NUTRIENT REGIME: PERMESOTROPHIC

ELEVATION: 1502(1402-1615)M

ASPECT: SOUTHERLY

SLOPE: $14(0-20) \%$

SOIL DRAINAGE: MOD. WELL

\section{FORAGE PRODUCTION(KG/HA)}

GRASS 642(364-812)

FORB 2262(214-6278)

SHRUB 62(0-198)

TOTAL 2766(624-6688)
SUGGESTED GRAZING CAPACITY

$0.6 \mathrm{HA} / \mathrm{AUM}$ 


\section{G12: Pb/Thimbleberry \\ (Populus balsamifera/Rubus parviflorus)}

$\mathbf{n}=\mathbf{2}$ This community type was described in the Southend allotment just north of Waterton Lakes National Park. It was found in a moist, nutrient rich, lower slope position, which favours the growth of both balsam poplar and thimbleberry. It is very similar to the Aw/Thimbleberry community previously described, but the higher elevation is out of the range of growth conditions for aspen. As a result, balsam poplar dominates the site.

PLANT COMPOSITION CANOPY COVER (\%) MEAN RANGE CONST.

TREeS

BALSAM POPLAR

(Populus balsamifera) $\quad 68 \quad 50-85 \quad 100$

$\begin{array}{lll}\text { ASPEN } & \\ \text { (Populus tremuloides) } \quad 22 & 3-40 \quad 100\end{array}$

SHRUBS

THIMBLEBERRY

$\begin{array}{llll}\text { (Rubus parviflorus) } \quad 39 & 30-58 \quad 100\end{array}$

WILLOW

(Salix spp.)

SNOWBERRY

(Symphoricarpos

occidentalis)

FORBS

JESSICA'S STICKSEED

(Hackelia jessicae)

SMOOTH SWEET CICELY

(Osmorhiza chilensis)

CANADA VIOLET

(Viola canadensis)

BANEBERRY

(Actaea rubra)

GREEN FALSE HELLEBORE

(Veratrum eschscholtzii)

$15 \quad 0-30 \quad 50$

$13 \quad 6-20 \quad 100$

$5 \quad 0-10 \quad 50$

$3 \quad 0-6 \quad 50$

$4 \quad 1-7 \quad 100$

$13 \quad 6-20 \quad 100$

$3 \quad 0-6 \quad 50$

\section{GRASSES}

ALASKA ONION GRASS

(Melica subulata)

NODDING TRISETUM

(Trisetum cernuum)

$1 \quad 0-2 \quad 50$

$2 \quad 1-3 \quad 100$

\section{ENVIRONMENTAL VARIABLES}

MOISTURE REGIME: SUBHYGRIC

NUTRIENT REGIME: PERMESOTROPHIC

ELEVATION: 1564(1420-1707) M

SLOPE: $4 \%$

ASPECT: SOUTHEAST

SOIL DRAINAGE: MODERATELY WELL

FORAGE PRODUCTION (KG/HA)

GRASS 36

FORB 1234

SHRUB 684

TOTAL 1954

SUGGESTED GRAZING CAPACITY

$0.9 \mathrm{HA} / \mathrm{AUM}$ 


\section{G13: $\mathrm{Pb} /$ Cow parsnip/Kentucky bluegrass \\ (Populus balsamifera/Heracleum lanatum/Poa pratensis)}

$\mathbf{n}=\mathbf{2}$ This community type occupies subhygric, lower slope positions. It is similar to the $\mathrm{Pb} / \mathrm{Thimbleberry}$ community type previously described, but lacks the cover of thimbleberry. Generally, thimbleberry is replaced by cow parsnip north of the Crowsnest Pass. The high moisture and nutrient content of this site make it highly productive. Domestic livestock find cow parsnip palatable. This community should be rated as secondary range.

Plant COMPOSITION CANOPY COVER (\%) MEAN RANGE CONST.

TREES

BALSAM POPLAR

$\begin{array}{llll}\text { (Populus balsamifera) } \quad 67 & 60-74 & 100\end{array}$

\section{SHRUBS}

STICKY CURRANT

(Ribes viscosissimum) $\quad 4 \quad 0-8 \quad 50$

RosE

(Rosa acicularis)

$3 \quad 0-5 \quad 50$

FORBS

SHOWY ASTER

(Aster conspicuus)

CANADA VIOLET

(Viola canadensis)

SWEET CICELY

(Osmorhiza chiiensis)

COW PARSNIP

(Heracleum lanatum)

VEINY MEADOW RUE

(Thalictrum venulosum)

GraSSES

SEDGE

$\begin{array}{llll}\text { (Carex spp.) } & 6 & 0-11 & 50\end{array}$

KENTUCKY BLUEGRASS

(Poa pratensis)

$\begin{array}{ccc}13 & 0-25 & 50 \\ 12 & 0-24 & 50 \\ 6 & 0-11 & 50 \\ 9 & 8-10 & 100 \\ 3 & 1-6 & 100\end{array}$

$10 \quad 10-10 \quad 100$

\section{ENVIRONMENTAL VARIABLES}

MOISTURE REGIME: SUBHYGRIC

NUTRIENT REGIME: PERMESOTROPHIC

ELEVATION: 1387(1350-1424) M

SLOPE: $3 \%$

ASPECT: SOUTHWEST

SOIL DRAINAGE: MODERATELY WELL

\section{FORAGE PRODUCTION(KG/HA)}

GRASS 4

FORB 856

SHRUB 1010

TOTAL $1870 *$ Estimate

SUGGESTED GRAZING CAPACITY

$1.0 \mathrm{HA} / \mathrm{AUM}$ 


\section{G14: Pb/Snowberry/Kentucky bluegrass \\ (Populus balsamifer/Symphoricarpos occidentalis/Poa pratensis)}

$\mathbf{n}=12$ This community is very similar to the $\mathrm{Pb} /$ Snowberry dominated community described by Archibald et al. (1996) on moist lower slope positions where seepage occurs in the spring or after heavy rain. It is also similar to the Spruce-Pb/Snowberry previously described, but this community is not as successionally advanced. The high moisture and nutrient content of the site makes this community highly productive, but the majority of the production is coming from snowberry which is generally unpalatable to livestock at proper stocking levels. This community should be rated as secondary range.

\section{Plant Composition CANopy Cover (\%)} MEAN RANGE CONST.

\section{TREES}

BALSAM POPLAR

(Populus balsamifera)

58

$30-65 \quad 100$

\section{SHRUBS}

SNOWBERRY

(Symphoricarpos

occidentalis,S. albus) $\quad 31 \quad 1-54 \quad 100$

THIMBLEBERRY

(Rubus parviflorus)

WATER BIRCH

(Betula occidentalis) $\quad 8 \quad 0-44 \quad 33$

\section{FORBS}

CANADA VIOLET

(Viola canadensis)

WILD WHITE GERANIUM

(Geranium richardsonii) $5 \quad 0-10 \quad 79$

VEINY MEADOW RUE

(Thalictrum occidentalis) $6 \quad 0-15 \quad 78$

DANDELION

$\begin{array}{llll}\text { (Taraxacum officinale) } & 6 & 1-20 & 100\end{array}$

STRAWBERRY

$\begin{array}{llll}\text { (Fragaria virginiana) } & 3 & 0-5 & 69\end{array}$

\section{GraSSES}

KENTUCKY BLUEGRASS

\begin{tabular}{llll}
$\begin{array}{l}\text { (Poa pratensis) } \\
\text { TIMOTHY }\end{array}$ & 6 & $0-20$ & 67 \\
$\begin{array}{l}\text { (Phleum pratense) } \\
\begin{array}{l}\text { KENTUCKY BLUEGRASS } \\
\text { (Poa pratensis) }\end{array}\end{array}$ & 6 & $0-40$ & 56 \\
\hline
\end{tabular}

\section{ENVIRONMENTAL VARIABLES}

MOISTURE REGIME: MESIC TO SUBHYGRIC

NUTRIENT REgIME: PERMESOTROPHIC

ELEVATION: 1450(1261-1527) M

SLOPE: $1(0-2) \%$

ASPECT: NORTH

SOIL DRAINAGE: MOD.WELL TO WELL

\section{FORAGE PRODUCTION(KG/HA)}

$\begin{array}{ll}\text { GrASS } & 382(44-732) \\ \text { FORB } & 483(224-646) \\ \text { SHRUB } & 893(530-1574) \\ \text { TOTAL } & 1760(1554-1884)\end{array}$

SUGGESTED GRAZING CAPACITY

$1.0 \mathrm{HA} / \mathrm{AUM}$ 


\section{G15: Aw-Pb/Birch-Willow \\ (Populus tremuloides/Betula occidentalis-Salix glauca)}

$\mathbf{n}=\mathbf{2}$ This community was described adjacent to a pond in the Southend allotment just north of Waterton Lakes National Park. Both water birch and smooth willow are well adapted to growing adjacent to streams and ponds. What is unusual about this community is the high aspen and pinegrass cover. Aspen and pinegrass are usually associated with more mesic sites. The high cover of willow, water birch and aspen limit the light reaching the forest floor. Therefore there is only moderate production for domestic livestock. This community should be rated as nonuse.

PLANT COMPOSITION CANOPY COVER (\%)

MEAN RANGE CONST.

TREES

\section{ASPEN}

(Populus tremuloides)

WHITE SPRUCE

(Picea glauca)

BALSAM POPLAR

(Populus balsamifera)

$$
45
$$$$
0-90
$$

50

$2 \quad 0-4 \quad 50$

30

$0-60$

50

\section{SHRUBS}

WATER BIRCH

(Betula occidentalis) $\quad 21 \quad 20-21 \quad 100$

SMOOTH WILLOW

(Salix glauca)

SNOWBERRY

(Symphoricarpos

occidentalis)

BUFFALOBERRY

(Shepherdia canadensis)

$11 \quad 0-21 \quad 50$

$7 \quad 0-14 \quad 50$

$1-14 \quad 100$

\section{ENVIRONMENTAL VARIABLES}

MOISTURE REGIME: SUBHYGRIC

NUTRIENT REGIME: PERMESOTROPHIC

ELEVATION: 1500(1400-1600)M

SOIL DRAINAGE: MODERATELY WELL TO POORLY

\section{FORAGE PRODUCTION(KG/HA)}

GRASS 804

FORB 452

SHRUB 622

TOTAL 1878

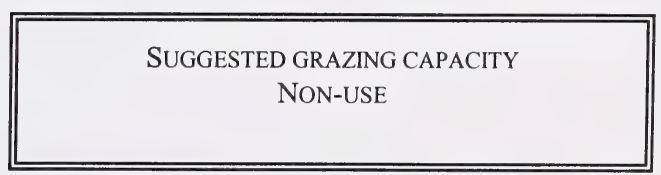

\section{FORBS}

SHOWY ASTER

(Aster conspicuus) $\quad 5 \quad 0-10 \quad 50$

STRAWBERRY

$\begin{array}{llll}\text { (Fragaria virginiana) } & 4 & 1-7 & 100\end{array}$

WINTERGREEN

$\begin{array}{llll}\text { (Pyrola asarifolia) } & 4 & 0-7 & 50\end{array}$

SMOOTH ASTER

$\begin{array}{llll}\text { (Aster laevis) } & 5 & 3-7 & 100\end{array}$

VEINY MEADOW RUE

(Thalictrum venulosum)

2

$1-4 \quad 100$

Grass

PINEGRASS

(Calamagrostis rubescens)7 $\quad 0-15 \quad 100$

KENTUCKY BLUEGRASS

(Poa pratensis)

$5 \quad 1-10 \quad 100$




\section{MONTANE CUTBLOCKS}

In order to classify the cutblocks of the Montane subregion properly and understand the successional sequences which occur after harvesting the preharvest community type and year the stand was harvested must be determined. This information was not available for this classification and therefore it was difficult to determine the successional pathways. For example many cutblocks in the Castle area and Porcupine Hills are not regenerating trees. It is not clear if these sites will always have difficulty growing trees because they were historically grasslands or if some other disturbance factor is influencing tree regeneration. Heavy grazing and competition from grass species can influence tree regeneration, heavy grazing pressure was described on a number of cutblocks in the Castle area. These cutblocks had been grazed so heavily that the agronomic species (Kentucky bluegrass, timothy and clover) dominated the sites and a number of sites had been seeded with creeping red fescue which can compete with tree seedlings for moisture and nutrients.

Cutblocks can be an important source of forage for domestic livestock. They produce on average twice as much as deciduous stands and nearly three times more than conifer stands. This production varies from area to area in the Montane. Generally the production averages 1800 to $1900 \mathrm{~kg} / \mathrm{ha}$ in the Castle and Porcupine Hills and drops dramatically in the Gap area to 700 $\mathrm{kg} / \mathrm{ha}$. It must be remembered that this increase in forage is only temporary. As the cutblock undergoes succession there will be a corresponding drop in forage production. Increases in carrying capacity after harvesting can be acquired through a temporary permit.

In order to understand the forage productivity on cutblocks between different areas of the Montane the cutblocks were split into the Gap, Castle and Porcupine Hills. It must be remembered that maximum forage productivity does not occur on a cutblock until it is approximately 3 years old. One year old cutblocks will generally have less than half the total production of a 3 year old block. 


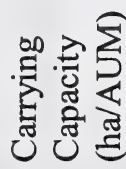

๙

芯

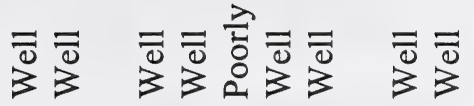

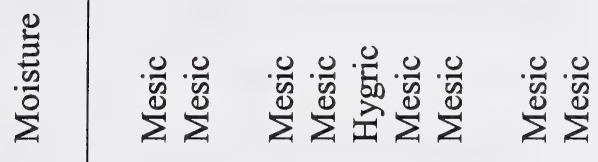

预

롤ㄹㄹㄹ

일

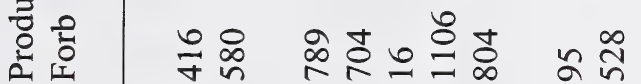

茕

离

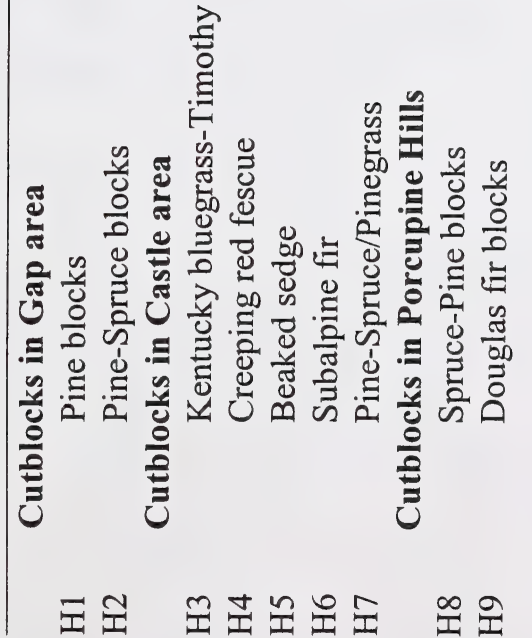

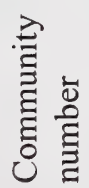

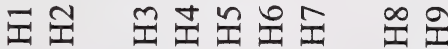




\section{H1: Pine blocks (Gap) (Pinus contorta)}

$\mathbf{n}=24$ These cutblocks were described in the Gap allotment just north of Crowsnest Mountain. These blocks are probably more representative of the Subalpine subregion than the Montane.

PLANT COMPOSITION CANOPY COVER (\%) MEAN RANGe CONTS.

TREES

LODGEPOLE PINE

(Pinus contorta)

WHITE SPRUCE

(Picea glauca)

SHRUBS

BRISTLY BLACK CURRANT

(Ribes lacustre)

$5 \quad 0-14 \quad 46$

FORBS

FIREWEED

(Epilobium angustifolium) 5

STRAWBERRY

$\begin{array}{llll}\text { (Fragaria virginiana) } & 12 & 0-30 & 96\end{array}$

HEART-LEAVED ARNICA

(Arnica cordifolia)

DANDELION

(Taraxacum officinale) 2

SMOOTH ASTER

(Aster laevis)

$\begin{array}{lll}6 & 0-20 & 75 \\ 3 & 0-14 & 46\end{array}$

$4 \quad 0-10 \quad 88$

$2 \quad 0-6 \quad 75$

$5 \quad 0-16 \quad 58$

GRASSES

PINEGRASS

(Calamagrostis rubescens)7

SEDGE SPP.

$0-31 \quad 83$

(Carex spp.)

5

HAIRY WILDRYE

(Elymus innovatus)

\section{ENVIRONMENTAL VARIABLES}

MOISTURE REGIME: Mesic

NUTRIENT REGIME: MESOTROPHIC

ELEVATION: 1767(1585-1890) M

SOIL DRAINAGE: WELL

\section{Forage Production KG/Ha}

$$
\begin{array}{ll}
\text { GrASS } & 307(0-962) \\
\text { FORB } & 416(140-586) \\
\text { SHRUB } & 15(0-84) \\
\text { TOTAL } & 739(408-1102)
\end{array}
$$

\section{SUGGESTED GRAZING CAPACITY $2.5 \mathrm{HA} / \mathrm{AUM}$}




\section{H2: Pine-Spruce blocks (Gap)}

(Pinus contorta-Picea glauca)

$n=6$

PLANT COMPOSITION CANOPY COVER (\%) MEan Range Const.

Trees

WHITE SPRUCE

(Picea glauca)

LODGEPOLE PINE

(Pinus contorta)

$\begin{array}{lll}15 & 1-40 & 100 \\ 12 & 0-40 & 89\end{array}$

\section{SHRUBS}

WILLOW SPP.

(Salix spp.)

FORBS

LINDLEY'S ASTER

(Aster ciliolatus)

WILD STRAWBERRY

(Fragaria virginiana)

FIREWEED

(Epilobium angustifolium)7

DANDELION

(Taraxacum officinale) $3 \quad 1-4 \quad 100$

FIELD HORSETAIL

(Equisetum arvense) $\quad 5 \quad 0-14 \quad 83$

GRASSES

SEDGE SPP.

(Carex spp.)

$22 \quad 12-34 \quad 100$

SLENDER WHEATGRASS

(Agropyron trachycaulum) $5 \quad 0-10 \quad 50$

PINEGRASS

(Calamagrostis rubescens)2

\section{ENVIRONMENTAL VARIABLES}

MOISTURE REGIME: MESIC

NUTRIENT REGIME: MESOTROPHIC

ELEVATION: 1752(1707-1829) M

SOIL DRAINAGE: WELL

\section{Forage Production KG/HA}

GRASS $112(0-276)$

FORB 580(0-950)

TOTAL 692(276-954)

SUGGESTED GRAZING CAPACITY $2.6 \mathrm{HA} / \mathrm{AUM}$ 


\section{H3: Kentucky bluegrass-Timothy (Castle) (Poa pratensis-Phleum pratense)}

$\mathbf{n}=12$ This community type represents cutblocks that have been heavily grazed by livestock. Heavy livestock grazing favours the growth of invaders Kentucky bluegrass and timothy. The grazing pressure which favours the growth of these grass species is usually detrimental to the growth of trees. Cattle damage to the conifer trees is usually trampling damage which scars the trees and breaks the stem.

Plant Composition Canopy Cover (\%)

\section{MEan Range Const.}

\section{TREES}

\section{WHITE SPRUCE}

(Picea glauca)

LODGEPOLE PINE

(Pinus contorta)

ASPEN

(Populus tremuloides)

$\begin{array}{lll}\mathrm{T} & 0-2 & 8 \\ 1 & 0-8 & 33\end{array}$

\section{SHRUBS}

WHITE MEADOWSWEET

(Spiraea betulifolia)

SASKATOON

(Amelanchier alnifolia)

8

$0-90$

2

$0-10$

$0-4 \quad 33$

\section{FORBS}

FIREWEED

(Epilobium angustifolium)4

STRAWBERRY

(Fragaria virginiana) $\quad 11 \quad 0-26 \quad 92$

ASTER SPP.

(Aster spp.)

$4 \quad 0-10 \quad 33$

YARROW

(Achillea millefolium)

$1-32 \quad 100$

\section{GrasseS}

KENTUCKY BLUEGRASS

$\begin{array}{llll}\text { (Poa pratensis) } & 31 & 11-91 & 100\end{array}$

SEDGE

(Carex spp.)

PINEGRASS

(Calamagrostis rubescens)

TiмотнY

(Phleum pratense)

\section{ENVIRONMENTAL VARIABLES}

MoISTURE REGIME: MESIC

NUTRIENT REGIME: MESOTROPHIC

ELEVATION RANGE : 1491(1372-1707) M

ASPECT: VARIABLE

SLOPE: $9(0-32) \%$

SOIL DRAINAGE: WELL

Forage Production KG/Ha

GRASS 1208(20-1578)

FORB 789(118-1220)

SHRUB $184(0-540)$

TOTAL 2181(1578-2686)

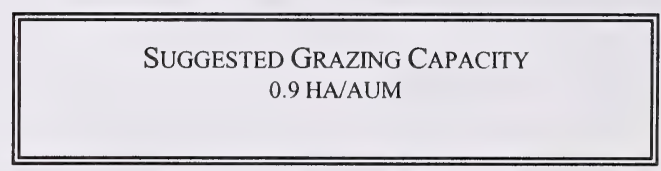




\section{H4: Creeping red fescue (Castle) \\ (Festuca rubra)}

$\mathbf{n}=7$ This community type represents cutblocks that have been heavily grazed and seeded with creeping red fescue. Creeping red fescue a rhizomatous grass can quickly form a sod on the top of the soil, which makes it difficult to grow trees. These seeded cutblocks can be very productive for domestic livestock, but it will be very difficult to regenerate trees on these sites.

Plant COMPOSITION CANOPY COVER (\%) Mean Range Const.

TREES

LODGEPOLE PINE

(Pinus contorta)

\section{SHRUBS}

WHITE MEADOWSWEET

(Spiraea betulifolia)

(Alnus crispa)

FORBS

STRAWBERRY

(Fragaria virginiana)

SHOWY ASTER

(Aster conspicuus)

LINDLEY'S ASTER

(Aster ciliolatus)

ClOVER

(Trifolium repens)

FIREWEED

(Epilobium angustifolium) 3

$1 \quad 0-9 \quad 14$

3

3

$0-13$

28

$0-54 \quad 43$
GREEN ALDER

GrasseS

KENTUCKY BLUEGRASS

$\begin{array}{llll}\text { (Poa pratensis) } & 2 & 0-8 & 43\end{array}$

TIMOTHY

(Phleum pratense)

CREEPING RED FESCUE

(Festuca rubra)

\section{ENVIRONMENTAL VARIABLES}

MOISTURE REGIME: MESIC

NUTRIENT REGIME: MESOTROPHIC

ELEVATION RANGE: 1560(1433-1829))M

SOIL DRAINAGE: WELL

\section{Forage Production KG/HA}

SUGGESTED GRAZING CAPACITY

1.1 HA/AUM 


\section{H5: Beaked sedge(Castle) \\ (Carex rostrata)}

$\mathbf{n = 1}$ This community was described in a moist, poorly drained spot within a Pine-Spruce cutblock. It is more representative of a wet sedge meadow. It is likely this community type will never grow trees because of the wet moisture conditions. These sites can be very productive for domestic livestock. When situated within a cutblock the livestock will utilize the drier edges of this community type extensively. This community type may also represent the only water to be found within a cutblock.

\section{Plant Composition Canopy Cover (\%) MEAN RANGE CONST.}

\section{FORBS}

NORTHERN WILLOWHERB

(Epilobium ciliatum) $\quad 4 \quad-\quad 100$

SWAMP HORSETAIL

$\begin{array}{llll}\text { (Equisetum fluviatile) } & 1 & - & 100\end{array}$

GraSSES

BEAKED SEDGE

(Carex rostrata)

NARROW REEDGRASS

(Calamagrostis stricta)

\section{ENVIRONMENTAL VARIABLES}

MOISTURE REGIME: HYGRIC

NUTRIENT REGIME: PERMESOTROPHIC

ELEVATION RANGE: $1430 \mathrm{M}$

SOIL DRAINAGE: POORLY

Forage Production KG/Ha

GRASS 3994

FORB 16

TOTAL 4010

SUGGESTED GRAZING CAPACITY

0.5 HA/AUM 


\section{H6: Subalpine fir blocks (Castle) \\ (Abies lasiocarpa)}

$\mathbf{n}=9$ These cutblocks represent higher elevation sites within the Castle area. Subalpine fir is usually indicative of the Subalpine subregion (Archibald et al. 1996).

\section{Plant COMPOSITION CANOPY COVER (\%) MEAN RANGE CONST.}

\section{TREES}

LODGEPOLE PINE

(Pinus contorta)

WHITE SPRUCE

(Picea glauca)

SUBALPINE FIR

(Abies lasiocarpa)

\section{SHRUBS}

THIMBLEBERRY

(Rubus parviflorus)

SNOWBERRY

(Symphoricarpos

occidentalis)

FALSE AZALEA

(Menziesia ferruginea)

3

$0-15 \quad 55$

$6 \quad 0-15 \quad 55$

$24 \quad 15-60 \quad 100$

$17 \quad 0-54 \quad 78$

$1 \quad 0-2 \quad 44$

$10 \quad 0-58 \quad 44$

\section{FORBS}

WILD STRAWBERRY

(Fragaria virginiana)

SHOWY ASTER

(Aster conspicuus)

WESTERN MEADOW RUE

(Thalictrum occidentalis)

FIREWEED

(Epilobium angustifolium) 9

\section{GRASSES}

PINEGRASS

(Calamagrostis rubescens)4

SEDGE SPP.

(Carex spp.)

KENTUCKY BLUEGRASS

(Poa pratensis)

$\begin{array}{lll}10 & 0-20 \quad 78\end{array}$

$3 \quad 0-9 \quad 67$

$0-14 \quad 67$

$1-29 \quad 100$

\section{$0-17 \quad 44$}

$0-16 \quad 56$

$2 \quad 0-8 \quad 33$

\section{ENVIRONMENTAL VARIABLES}

MOISTURE REGIME: MESIC

NUTRIENT REGIME: MESOTROPHIC

ELEVATION: 1652(1494-1798)M

ASPECT: VARIABLE

SLOPE: $21(8-37) \%$

SOIL DRAINAGE: MODERATELY WELL

\section{Forage Production Kg/Ha}

$$
\begin{array}{ll}
\text { GRASS } & 550(32-1030) \\
\text { FORB } & 1106(470-1802) \\
\text { SHRUB } & 190(0-650) \\
\text { TOTAL } & 1846(1222-2484)
\end{array}
$$

\section{SUGGESTED GRAZING CAPACITY} $1.0 \mathrm{HA} / \mathrm{AUM}$

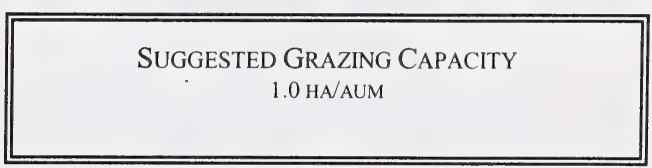




\section{H7: Pine-Spruce/Pinegrass (Castle) \\ (Pinus contorta-Picea glauca/Calamagrostis rubescens)}

$\mathbf{n}=56$ This community type is typical of undisturbed cutblocks in the Castle area of the province. Many of these cutblocks are not regenerating trees. It is not clear if these sites are not regenerating trees because they were historically grasslands or if some other factor is influencing tree regeneration.

\section{PLANT COMPOSITION CANOPY COVER (\%) \\ MEAN RANGe Const.}

TREES

LODGEPOLE PINE

(Pinus contorta)

WHITE SPRUCE

(Picea glauca)

$\begin{array}{lll}10 & 0-30 & 90 \\ 5 & 0-40 & 59\end{array}$

SHRUBS

WHITE MEADOWSWEET

(Spiraea betulifolia)

THIMBLEBERRY

(Rubus parviflorus)

SNOWBERRY

(Symphoricarpos

occidentalis)

$3 \quad 0-25 \quad 63$

FORBS

STRAWBERRY

(Fragaria virginiana) $\quad 11 \quad 0-28 \quad 89$

FIREWEED

(Epilobium angustifolium)5

AMERICAN VETCH

(Vicia americana)

$3 \quad 0-11 \quad 71$

YELLOW PEAVINE

$\begin{array}{llll}\text { (Lathyrus ochroleucus) } & 3 & 0-6 & 68\end{array}$

SHOWY ASTER

(Aster conspicuus)

$3 \quad 0-5 \quad 58$

GraSSES

PINEGRASS

(Calamagrostis rubescens) $15 \quad 0-42 \quad 64$

KENTUCKY BLUEGRASS

(Poa pratensis) $\quad 4 \quad 0-6 \quad 71$

SEDGE SPP.

(Carex spp.)

Tiмотну

(Phleum pratense)

$5 \quad 0-28 \quad 46$

$2 \quad 0-13 \quad 48$

\section{ENVIRONMENTAL VARIABLES}

MOISTURE REGIME: MESIC

NUTRIENT REGIME: MESOTROPHIC

ELEVATION: $1529(1432-1800) \mathrm{M}$

ASPECT: VARIABLE

SLOPE: $13(0-33) \%$

SOIL DRAINAGE: WELL

\section{Forage Production KG/HA}

SUGGESTED GRAZING CAPACITY

$1.1 \mathrm{HA} / \mathrm{AUM}$
GRASS $\quad 689(42-2698)$

FORB 804(104-1732)

SHRUB $158(0-588)$

TOTAL 1646(378-3582)

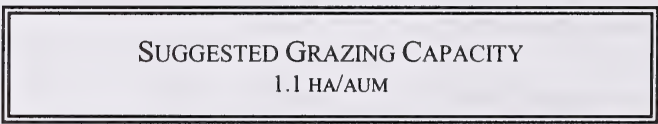




\section{H8: Pine blocks (Porcupine hills) \\ (Pinus contorta)}

$\mathbf{n}=4$ This community type is typical of undisturbed cutblocks with northerly aspects in the Porcupine Hills. Many of these cutblocks are not regenerating trees. It is not clear if these sites will always have difficulty growing trees because they were historically grasslands or if some other factor is influencing tree regeneration.

\section{PLANT COMPOSITION CANOPY COVER (\%) MEAN RANGe Const.}

\section{TREES}

LODGEPOLE PINE

(Pinus contorta)

ASPEN

(Populus tremuloides)

$1 \quad 0-1 \quad 25$

$0-3 \quad 50$

\section{SHRUBS}

ROSE

(Rosa acicularis)

RASPBERRY

(Rubus idaeus)

WHITE MEADOWSWEET

(Spiraea betulifolia)

THIMBLEBERRY

(Rubus parviflorus)

FORBS

STRAWBERRY

(Fragaria virginiana)

HEART-LEAVED ARNICA

(Arnica cordifolia)

SHOWY ASTER

(Aster conspicuus)

BUNCHBERRY

(Cornus canadensis)

\section{GRASSES}

HAIRY WILD RYE

$\begin{array}{llll}\text { (Elymus innovatus) } & 4 & 0-10 & 75\end{array}$

PINEGRASS

(Calamagrostis rubescens) $15 \quad 1-27 \quad 100$

\section{ENVRIONMENTAL VARIABLES}

MOISTURE REGIME: MESIC

NUTRIENT REGIME: MESOTROPHIC

ELEVATION RANGE: 1500(1485-1524) M

ASPECT: SOUTH TO SOUTHWEST

SLOPE: $13(10-15) \%$

SOIL DRAINAGE: WELL

\section{Forage Production KG/HA}

GRASS 707(292-1224)

FORB 95(20-158)

SHRUB 62(0-152)

TOTAL 864(312-1534)

SugGESTEd GRAZING CAPACITY

$2.1 \mathrm{HA} / \mathrm{AUM}$ 


\section{H9: Douglas fir blocks (Porcupine hills) \\ (Pseudotsuga menziesii)}

$\mathbf{n = 4}$ This community type is typical of undisturbed cutblocks with south and west aspects in the Porcupine Hills. Many of these cutblocks are not regenerating trees. It is not clear if these sites will always have difficulty growing trees because they were historically grasslands or if some other factor is influencing tree regeneration.

\section{Plant COMPOSITION Canopy Cover(\%)$$
\text { MEAN RANGE CONST. }
$$

TREES

\section{ASPEN}

(Populus tremuloides)

$1 \quad 0-3 \quad 25$

SHRUBS

ROSE

(Rosa acicularis) $\quad 2 \quad 1-4 \quad 100$

RASPBERRY

(Rubus idaeus)

WHITE MEADOWSWEET

(Spiraea betulifolia) $\quad 2 \quad 1-4 \quad 100$

FORBS

STRAWBERRY

(Fragaria virginiana)

HEART-LEAVED ARNICA

(Arnica cordifolia) $\quad 5 \quad 0-10 \quad 75$

SHOWY ASTER

$\begin{array}{llll}\text { (Aster conspicuus) } & 9 & 3-15 & 100\end{array}$

BUNCHBERRY

(Cornus canadensis) $\quad 4 \quad 0-8 \quad 75$

\section{GRASSES}

HAIRY WILD RYE

(Elymus innovatus) $\quad 16 \quad 8-31 \quad 100$

PINEGRASS

(Calamagrostis rubescens) $10 \quad 0-32 \quad 75$

\section{ENVRIONMENTAL VARIABLES}

MOISTURE REGIME: SUBMESIC-MESIC

NUTRIENT REGIME: MESOTROPHIC

ELEVATION RANGE: 1608(1524-1676) M

ASPECT: SOUTH TO SOUTHWEST

SLOPE: $16(10-30) \%$

SOIL DRAINAGE: WELL

\section{Forage Production KG/HA}

$\begin{array}{ll}\text { GRASS } & 1710(846-2778) \\ \text { FORB } & 528(386-606) \\ \text { SHRUB } & 191(68-422) \\ \text { TOTAL } & 2429(1300-3806)\end{array}$

SUGGESTED GRAZING CAPACITY

$0.8 \mathrm{HA} / \mathrm{AUM}$ 


\section{MONTANE SUBREGION}

\section{CYPRESS HILLS ECODISTRICT}

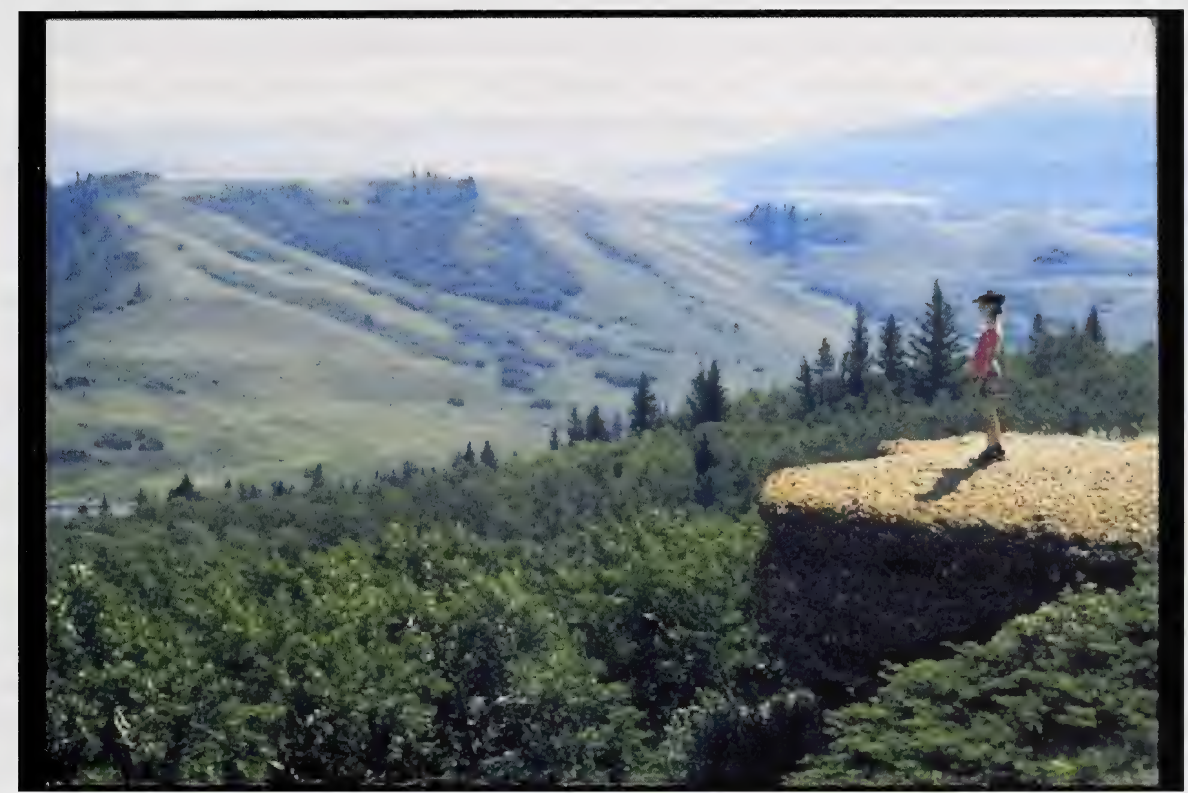

Photo 11. This photo is typical of the mosaic of plant communities found in the Cypress Hills. The northerly aspects are dominated by trees and the south and western facing slopes are dominated by grasslands with shrubs growing in the moist draws. 


\section{Cypress Hills ecodistrict}

The Cypress Hills ecodistrict is an unglaciated plateau ranging in elevation from about $1300 \mathrm{~m}$ in the east to $1465 \mathrm{~m}$ at the highest point. Once considered boreal foothills, the area has been reclassified as montane given the bimodal summer precipitation peaks (June and September), the potential for freezing temperatures in all months and the combination of closedcanopied lodgepole pine forest with fescue grassland (Strong and Leggatt 1992). Soil parent materials are somewhat unique on the plateau where ancient tertiary gravels are exposed, or, may be capped by a variable veneer of loess; fine silty material deposited by wind from post glacial lake beds to the west of the plateau. Soils are mostly Black Chernozems where grassland vegetation has dominated. Thelma soils are loamy Orthic Black Chernozems associated with rough fescue communities on the top of the bench. Also associated with rough fescue cover, Delmas and Marmaduke soil series are gravel and shallow to gravel Orthic Dark Brown Chernozems found on the shoulder of the escarpment. Orthic Dark Grey Luvisols, like the soils series Reesor (loamy) have developed where lodgepole pine or aspen forest have prevailed (Greenlee 1981).

Plant communities described in the Cypress Hills are associated with the nearly level plateau or the upper edges of the steep escarpment or rolling uplands. They include a mixture of rough fescue grassland and closed canopy aspen and lodgepole pine dominated forests. The Rough fescue (Festuca campestris Rydb.) related plant communities of the Cypress Hills Plateau are unique in the relatively high canopy of Shrubby Cinquefoil (compared to fescue communities described in southwestern Alberta and appears to be a function of the gravelly soil) and the abundance of Intermediate oat grass, a major subdominant grassland species (Moss 1955). On the steep, dry slopes Western Porcupine grass often replaces Intermediate oatgrass in these grassland communities. Idaho fescue also replaces Intermediate oatgrass on shallower soils with gentler slopes. An unresolved issue is the apparent expression of Rough fescue as the Foothills Rough fescue (F. campestris Rydb.) bunch grass type on the top of the plateau and the Plains Rough fescue (F. hallii Vassey) rhizomatous form on the adjoining slopes of the Cypress Hills. 


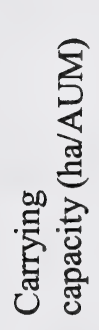

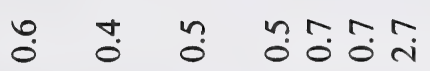

$\begin{array}{lll}\overline{0} & \overline{0} & \overline{0} \overline{0} \overline{0} \\ 3 & 3 & 3\end{array}$

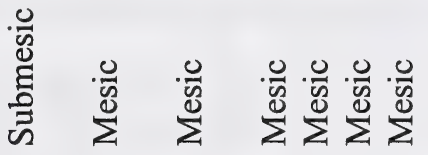

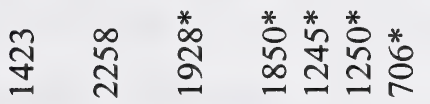

$\sum_{0}^{3} \frac{\pi}{0}$

焉

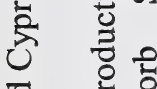

ส

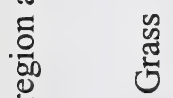

ชู $\stackrel{\infty}{\sim}$

.๘)

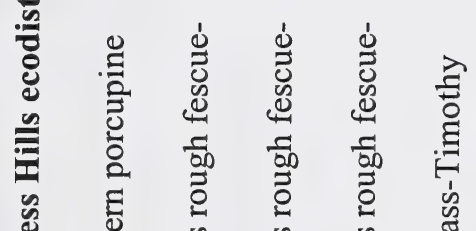

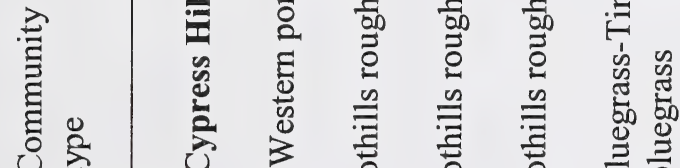

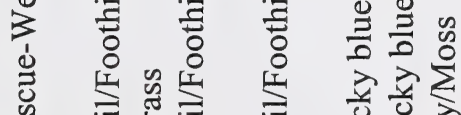

嵌

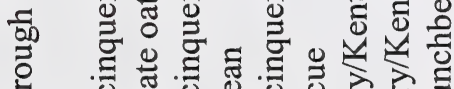

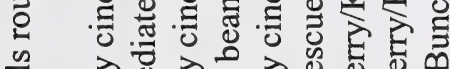

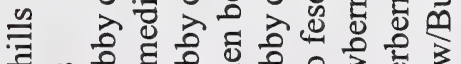

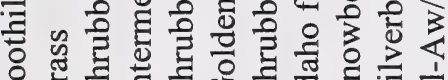

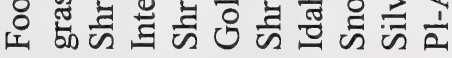

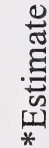

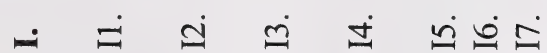




\section{Key to grassland community types in the Cypress Hills ecodistrict}

1. Shrubby cinquefoil or rough fescue dominated sites.

Moister sites dominated by snowberry or

silverberry.

2. Shrubby cinquefoil dominated communities

Shrubby cinquefoil greatly reduced, site is found on slopes and dominated by Foothills rough fescue and

Western porcupine grass.

Foothills rough fescue-Western porcupine grass $\underline{\text { I1 }}$

3. Ungrazed communities dominated by rough fescue and codominated by Intermediate oatgrass or Idaho fescue. 4

Patched grazed community dominated by rough fescue and golden bean .. Shrubby cinquefoil/Foothills rough fescue-Golden bean $\underline{\mathbf{I 3}}$

4. Modal grassland community codominated by Intermediate oatgrass.. Shrubby cinquefoil/Foothills rough fescue-Intermediate oatgrass $\underline{\mathbf{I 2}}$ Site with shallower soils codominated by Idaho fescue....Shrubby cinquefoil/Foothills rough fescue-Idaho fescue $\underline{\mathbf{I}}$

5. Seepage area dominated by silverberry. Silverberry/Kentucky bluegrass $\underline{\mathbf{I}} \underline{5}$ Seepage area dominated by snowberry. Snowberry/Kentucky bluegrass $\underline{\mathbf{I}}$ 


\section{I1. Foothills Rough Fescue - Western Porcupine Grass}

(Festuca campestris - Stipa curtiseta) Shrub Herbaceous

$\mathbf{n}=10$ This is the reference plant community for thin break and gravel range sites in the upper slopes of the Cypress Hills. There remains some uncertainty about the species of rough fescue found from the upper slopes of the Cypress Hills, down slope to the lower slopes of the mixed grassed. On the Cypress Hills bench, rough fescue expresses as a bunch grass and then as a sod forming species as you progress downslope. Genetic studies proposed by Agriculture Canada may clear up this point of confusion in the future. Coupland (1961) described this plant community and our analysis suggests that it is found on the drier thin break and gravel influenced sites adjoining the Cypress Hills plateau and upper slopes. This community is very similar to the MGAl community in the adjoining mixed grass natural subregion. Subdominant species in this community more closely resemble the shrubby cinquefoil/rough fescue-Intermediate oatagrass community of the plateau, while the MGA1 more closely resembles the adjoining dry mixed grass prairie. Mid-summer aridity is a common feature of these rangeland soils given their exposure and coarse texture. Conservative stocking rates are needed to require adequate litter. Productivity data is presented from the Blue Field rangeland reference area.

Soil Exposure: $6 \%(0-17)$

Moss/Lichen Cover: 3 \% (0-11) Total Vegetation: 84 \% (67-95)

\section{Plant CoMposition Canopy Cover(\%)} Mean Range Const

SHRUBS

SILVERBERRY

(Elaeagnus commutata)

COMMON WILD ROSE

(Rosa woodsii)

FORBS

GOLDEN BEAN

(Thermopsis rhombifolia)4

(Artemisi frigida)

2

$0-8$

90

$0-5 \quad 80$

GRASSES

FOOTHILLS ROUGH FESCUE

(Festuca campestris) 18

WESTERN PORCUPINE GRASS

(Stipa curtiseta) $\quad 10$

SEDGE

(Carex spp.)

6

NORTHERN WHEAT GRASS

(Agropyron dasystachyum) 6

HOOKER'S OAT GRASS

(Helictotrichon hookeri) 5
JUNE GRASS

(Koeleria macrantha) 4

BLUEBUNCH FESCUE

(Festuca idahoensis)

KENTUCKY BLUEGRASS

(Poa pratensis)

$0-5 \quad 30$

$0-13 \quad 70$

(1)

0

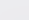

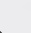

80

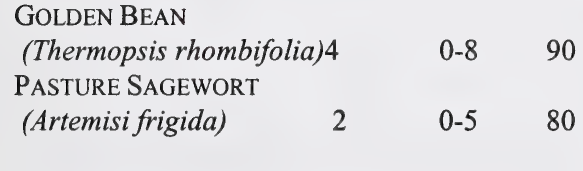




\section{2. Shrubby Cinquefoil/Foothills Rough Fescue - Intermediate Oat Grass (Potentilla fruticosa/Festuca campestris - Danthonia intermedia) Shrub Herbaceous}

$\mathbf{n}=37$ This is the reference plant community for loamy and shallow-to-gravel range sites on top of the Cypress Hills plateau at about 1400 m elevation, and is associated with Thelma (THA) soils, orthic black chernozems developed on loess deposits over tertiary gravels. Rough fescue expresses itself as the F. campestris, bunch grass type on the plateau while it appears as F. hallii, the rhizomatous type on the upper breaks and slopes of the plateau. This plant community has been described by Moss (1955) and Coupland (1961) who noted intermediate oatgrass as key subdominant species to rough fescue on the Cypress Hills plateau, vs. Parry's oatgrass in montane grasslands of southwestern Alberta (Willoughby et al 2001). Shrubby cinquefoil contributes a much higher canopy cover in this community type at a mean cover of $14 \%$ versus about $3 \%$ in the foothills Montane community described by Willoughby et al 2001. Shrubby cinquefoil, intermediate oatgrass, Idaho fescue and a number of forb species will increase with grazing pressure. With control of wildfires, this community appears to be vulnerable to conifer encroachment, especially lodgepole pine. Like foothill rough fescue communities, this community tends to have low soil exposure and a low cover of moss and lichen. The community is highly productive and in the absence of grazing or fire will produce a very heavy litter build up. In the absence of grazing rough fescue will grow to the exclusion of other species (Moss and Campbell 1947).

Soil Exposure: 0(0-1) Moss/Lichen Cover: 3 \% (0-98)

Total Vegetation: $90 \%(4-98)$

\section{Plant COMPOSITION CANOPY COVER(\%) Mean Range Const}

SHRUBS

SHRUBBY CINQUEFOIL

(Potentilla fruticosa)

$14 \quad 0-47 \quad 95$

FORBS

SILVERY PERENNIAL LUPINE

(Lupinus argenteus) 3

THREE-FLOWERED AVENS

(Geum triflorum) 4

NORTHERN BEDSTRAW

(Galium boreale)

3

\section{Grasses}

FOOTHILLS ROUGH FESCUE

(Festuca campestris) 38

INTERMEDIATE OAT GRASS

(Danthonia intermedia) 12

BLUEBUNCH FESCUE

(Festuca idahoensis)

SUN-LOVING SEDGE

(Carex pensylvanica)

SLENDER WHEAT GRASS

(Agropyron unilaterale)

KENTUCKY BLUEGRASS

(Poa pratensis)

0-17 73

$3 \quad 0-10 \quad 92$

COMMON YARROW

(Achillea millefolium)
NORTHERN WHEAT GRASS
(Agropyron dasystachyum)1
0-12 35

ENVIRONMENTAL VARIABLES

RANGE SITE

LOAMY, SHALLOW TO GRAVEL

SOILS

ORTHIC BLACK (THELMA)

OTHIC DARK BROWN (MARAMDUKE)

ELEVATION (M):

M 1400

SOIL DRAINAGE:

WELL DRAINED

SLOPE :

LEVEL

ASPECT:

$\mathrm{N} / \mathrm{A}$

Forage ProduCtion (KG/HA)

GRASS $1980(1577-2650)$

FORB $278(130-550)$

SHRUB Not AVAILABLE

TOTAL 2258

LITTER $2959(1902-5405)$

SUGGESTED GRAZING CAPACITY

$0.4 \mathrm{HA} / \mathrm{AUM}$ 


\section{I3. Shrubby Cinquefoil / Foothills Rough Fescue -Golden Bean \\ (Potentilla fruticosa / Festuca campestris - Thermopsis rhombifolia) Herbaceous Shrub}

$\mathbf{n}=17$ This is a mid to late seral plant community on loamy and shallow-to-gravel range sites on the top of the Cypress Hills plateau, and is associated with orthic black chernozems (Thelma) and orthic dark browns (Marmaduke). This plant community has a mixed structure of lightly grazed and heavily grazed patches that results in many fescue grasslands as a result of light stocking and summer grazing use. Cattle will graze rough fescue more uniformly under winter grazing use but under summer grazing will often choose other associated species first (Willms and Rode 1997). More heavily grazed micro patches will be dominated by intermediate oatgrass and forbs and taller and more rank cover will be dominated by shrubby cinquefoil and rough fescue.

Soil Exposure: $1 \%(0-6)$

Moss/Lichen Cover: $0 \%(0-2)$

Total Vegetation: $96 \%(88-98)$

Plant Composition Canopy Cover(\%) MEAN RANGe CONST

SHRUBS

SHRUBBy CINQUEFOIL

(Potentilla fruticosa)

5

$0-21$

53

\section{FORBS}

\section{GOLDEN BEAN}

(Thermopsis rhombifolia) 10

SILVERY PERENNIAL LUPINE

(Lupinus aregenteus) 4

$$
\text { 4-18 } \quad 100
$$

$0-16 \quad 53$

\section{GRASSES}

FoOTHILLS ROUGH FESCUE

(Festuca campestris) 44

NORTHERN WHEAT GRASS

(Agropyron dasystachyum) 2

INTERMEDIATE OAT GRASS

(Danthonia intermedia) 10

SUN-LOVING SEDGE

(Carex pensylvanica) 2

BLUEBUNCH FESCUE

(Festuca idahoensis)

SLENDER WhEAT GRASS

(Agropyron unilaterale)

HOOKER's OAT GRASS

(Helictotrichon hookeri) 1

JUNE GRASS

(Koeleria macrantha)

\section{ENVIRONMENTAL VARIABLES}

RANGE SITE

LOAMY AND SHALLOW TO GRAVEL

SoILS

\author{
ORTHIC BLACK (THELMA) \\ ORTHIC DARK BROWN (MARMADUKE)
}

ELEVATION (M): $1400 \mathrm{M}$

SOIL DRAINAGE:

WELL DRAINED

SLOPE :

LEVEL

ASPECT:

NORTHERLY

\section{Forage ProduCtion (KG/HA)}

GRASS NOT AVAILABLE

FORB NOT AVAILABLE

SHRUB Not AVAILABLE

LITTER NOT AVAILABLE

TOTAL $1928 *$ ESTIMATE

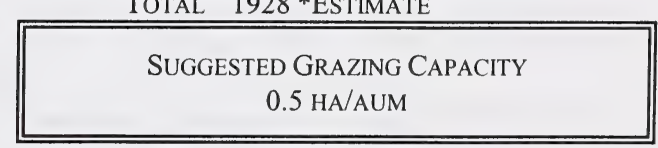




\section{I4. Shrubby Cinquefoil / Foothills Rough Fescue - Idaho Fescue \\ (Potentilla fruticosa / Festuca campestris - Festuca idahoensis) Herbaceous Shrub}

$\mathbf{n}=6 \quad$ This is a reference plant community for shallow-to-gravel range sites on the Cypress Hills Plateau. Though the shrubby cinquefoil/foothills rough fescue - intermediate oatgrass community type is most common on the plateau, this community type occurs on similar soils but with thinner loess deposits over gravels (Thelma and Marmaduke). This community type tends to have a lower canopy cover of shrubby cinquefoil and a greater ground cover of moss/lichen compared to I2. With grazing pressure, Idaho fescue and forb cover will increase significantly.

\section{PLANT COMPOSITION CANOPY COVER(\%)} MEAN Range Const

SHRUBS

SHRUBBY CINQUEFOIL

(Potentilla fruticosa)

$5 \quad 0-13 \quad 83$

\section{FORBS}

NORTHERN BEDSTRAW

\section{(Galium boreale)} 3

ALPINE HEDYSARUM

(Hedysarum alpinum)

SHINING ARNICA

(Arnica fulgens)

Slender Blue BeARdtongue

(Penstemon procerus) 1

SILKY PERENNIAL LUPINE

(Lupinus sericeus)

1

GOLDEN BEAN

(Thermopsis rhombifolia) 1

\section{Grasses}

FOOTHILLS ROUGH FESCUE

$\begin{array}{llll}\begin{array}{l}\text { (Festuca campestris) } \\ \text { BLUEBUNCH FESCUE }\end{array} & 52 & 23-80 & 100 \\ \begin{array}{l}\text { (Festuca idahoensis) } \\ \text { INTERMEDIATE OAT GRASS }\end{array} & 10 & 1-22 & 100 \\ \begin{array}{l}\text { (Danthonia californica) } \\ \text { SUN-LOVING SEDGE }\end{array} & 9 & 2-19 & 100 \\ \begin{array}{l}\text { (Carex pensylvanica) } \\ \text { SEDGE }\end{array} & 1 & 0-2 & 67 \\ \text { (Undifferentiated Sedge) } & 1 & 0-3 & 33\end{array}$

\section{ENVIRONMENTAL VARIABLES}

RANGE SITE

SHALlOW TO GRAVEL

SoILS

ORTHIC BLACK (THELMA)

ORTHIC DARK BROWN (MARMADUKE)

EleVATION (M):

1400

SOIL DRAINAGE:

WELL DRAINED

SLOPE :

LELVEL

ASPECT:

\section{Forage Production (KG/HA)}

Grass Not AVAilable

FORB NOT AVAILABLE

SHRUB NOT AVAILABLE

LiTTER NOT AVAILABLE

TOTAL $1850^{*}$ Estimate

\section{SUGGESTED GRAZING CAPACITY \\ $0.5 \mathrm{HA} / \mathrm{AUM}$}




\section{I5. Buckbrush / Kentucky Bluegrass - Timothy \\ (Symphoricarpos / Poa pratensis - Phleum pratense) Shrub Herbaceous}

$\mathbf{n}=3$ This is a modified plant community where disturbance history has resulted in the replacement of native species by invasive agronomic species and weeds. This plant community may provide reasonable forage production during wet years but will produce little forage in average moisture to dry years. Forage quality declines rapidly as forages mature and the community has little value for dormant season grazing. Based on current knowledge, there seems to be little potential for this community to recover to a native stand. Grazing management should aim to promote vigor and productivity of Timothy and Brome grass to reduce the relative cover of Kentucky bluegrass and provide more competition to weed species like Canada thistle.

Soil Exposure: $0 \%(0-0)$

Moss/Lichen Cover: $0 \%(0-0)$

Total Vegetation: $98 \%(98-$

98)

\section{Plant COMPOSITION CANopy Cover(\%)}

MEan RANGe Const

\section{SHRUBS}

BUCKBRUSH

(Symphoricarpos

occidentalis)

$25 \quad 19-30 \quad 100$

\section{FORBS}

CANADA Thistle

$\begin{array}{lccc}\begin{array}{l}\text { (Cirsium arvense) } \\ \text { COMMON GOAT's BEARD }\end{array} & 5 & 0-10 & 67 \\ \begin{array}{l}\text { (Tragopogon dubius) } \\ \text { TUFTED WHITE PRAIRIE }\end{array} & 5 & 0-14 & 33 \\ \begin{array}{l}\text { Aster } \text { ericoides) } \\ \text { GOLDEN BEAN }\end{array} & 2 & 0-5 & 67\end{array}$

(Thermopsis rhombifolia)2 $\quad 0-4 \quad 67$

GraSSES

KENTUCKY BLUEGRASS

\begin{tabular}{|c|c|c|c|}
\hline (Poa pratensis) & 39 & $22-66$ & 100 \\
\hline TIMOTHY & & & \\
\hline (Phleum pratense) & 5 & $0-14$ & 67 \\
\hline $\begin{array}{l}\text { AWNLESS BROME } \\
\text { (Bromus inermis) }\end{array}$ & & & \\
\hline $\begin{array}{l}\text { (Bromus inermis) } \\
\text { SLENDER WHEAT GRASS }\end{array}$ & 5 & $0-16$ & 33 \\
\hline (Agropyron unilaterale) & 1 & $0-4$ & 33 \\
\hline $\begin{array}{l}\text { NORTHERN WHEAT GRAS } \\
\text { (Agropyron dasystachyu }\end{array}$ & & $0-3$ & 33 \\
\hline GREEN NEEDLE GRASS & & & \\
\hline (Stipa viridula) & 1 & $0-2$ & 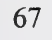 \\
\hline FOOTHILLS ROUGH FESCU & & & \\
\hline (Festuca campestris) & 1 & $0-2$ & נJ \\
\hline
\end{tabular}

\section{ENVIRONMENTAL VARIABLES}

RANGE SITE

SoILS

LOAMY, GRAVEL, SHALlOW-TO-GRAVEL

ORTHIC BLACK (DEMPSTER, THELMA)

ORTHIC DARK BROWN (MARMADUKE)

ELEVATION (M):

$1400 \mathrm{M}$

SOIL DRAINAGE:

WeLl DRAINED

SLOPE :

NEARLY LEVEL

ASPECT:

Forage Production (KG/HA)

GRASS NOT AVAILABLE

Forb NOT AVAILABLE

Shrub Not Avallable

LITTER NOT AVAILABLE

TOTAL $1250 *$ ESTIMATE

\section{SUGGESTED GRAZING CAPACITY}

$0.7 \mathrm{HA} / \mathrm{AUM}$ 


\section{I6. Silverberry / Kentucky Bluegrass \\ (Elaeagnus commutata / Poa pratensis) Shrub Herbaceous}

$\mathbf{n}=1 \quad$ The silverberry dominated plant communities occur on alluvial floodplain terraces, in $\mathrm{V}$-shaped ravines and swale-like depressions where overland flows provide additional moisture (Thompson and Hansen 2002). Where silverberry is very dense forage production is very low, however in more open stands livestock use can be extensive which leads to the invasion of Kentucky bluegrass, Timothy and dandelion. In the absence of disturbance silverberry dominated communities can undergo succession to aspen or balsam poplar and then white spruce.

\section{Plant COMPOSITION CANOPY COVER(\%)} MEAN RANGe CONST

\section{SHRUBS}

SILVERBERRY

$\begin{array}{llll}\text { (Elaeagnus commutata) } & 30 & - & 100\end{array}$

ROSE

$\begin{array}{llll}\text { (Rosa acicularis) } & 20 & - & 100\end{array}$

BEBB WILLLOW

(Salix bebbiana)

\section{FORBS}

DANDELION

$\begin{array}{llll}\text { (Taraxacum officinale) } & 10 & - & 100\end{array}$

ClOVER

(Trifolium repens)

GIANT GOLDENROD

(Solidago gigantea)

CANADA THISTLE

(Cirsium arvense)

GRASSES

KENTUCKY BLUEGRASS

(Poa pratensis)

TімоTHY

(Phleum pratense)

AWNLESS BROME

(Bromus inermis)

BALTIC RUSH

(Juncus balticus)

\section{ENVIRONMENTAL VARIABLES}

RANGE SITE

LOAMY, GRAVEL, SHALLOW-TO-GRAVEL

SOILS

ORTHIC BLACK (DEMPSTER, THELMA)

ORTHIC DARK BROWN (MARMADUKE)

ELEVATION (M):

$1400 \mathrm{M}$

SOIL DRAINAGE:

WELL DRAINED

SLOPE :

NEARLY LEVEL

ASPECT:

SCUTH AND WEST

\section{Forage Production (KG/HA)}

GRASS NOT AVAILABLE

FORB NOT AVAILABLE

SHRUB Not AVAILABLE

LITTER NOT AVAILABLE

TOTAL $1250 *$ ESTIMATE

SUGGESTED GRAZING CAPACITY

$0.7 \mathrm{HA} / \mathrm{AUM}$ 


\section{I7. Pl-Aw/Bunchberry/Moss \\ (Pinus contorta-Populus tremuloides/Cornus canadensis/Pleurozium schreberi)}

$\mathbf{n}=18$ This community is found on northerly aspects, which probably escaped fire and disturbance, allowing succession to occur. Continued succession in the absence of disturbance will likely be to the Sw/Moss dominated community type. This community type is moderately productive for domestic livestock. The higher moisture conditions favour the growth of fireweed and aster spp. These species are moderately palatable to livestock. This community type would be rated as secondary range for domestic livestock.

\section{PLANT COMPOSITION CANOPY COVER(\%)}

MEAN RANGe Const.

TREES

ASPEN

(Populus tremuloides)

LODGEPOLE PINE

(Pinus contorta)

$20 \quad 10-30 \quad 100$

$42 \quad 13-69 \quad 100$

\section{SHRUBS}

SNOWBERRY

(Symphoricarpos albus) $4 \quad 0-21 \quad 83$

WHITE MEADOWSWEET

(Spiraea betulifolia) $\quad 5 \quad 0-18 \quad 61$

ROSE

(Rosa acicularis)

$3 \quad 0-18 \quad 78$

\section{ENVIRONMENTAL VARIABLES}

MOISTURE REGIME: MESIC

NUTRIENT REGIME: MESOTROPHIC

ELEVATION: $1287 \mathrm{M}$

\section{ASPECT: NORTHERLY}

SLOPE: $15(3-45) \%$

DRAINAGE: MODERATELY WELL

\section{FORBS}

STRAẄBERRY

$\begin{array}{llll}\text { (Fragaria virginiana) } & 4 & 1-8 & 100\end{array}$

FIREWEED

$0-1$

(Epilobium angustifolium) $1 \quad 0-1 \quad 17$

LINDLEY'S ASTER

$\begin{array}{llll}\text { (Aster ciliolatus) } & 4 & 0-9 & 94\end{array}$

CANADA VIOLET

$\begin{array}{llll}\text { (Viola canadensis) } & 2 & 0-10 \quad 67\end{array}$

WESTERN MEADOW RUE

$\begin{array}{llll}\text { (Thalictrum occidentale) } & 3 & 0-9 & 83\end{array}$

GRASSES

MOUNTAIN RICEGRASS

(Oryzopsis asperfolia) $\quad 10 \quad 0-30 \quad 89$

PINEGRASS

(Calamagrostis rubescens)6 $\quad 0-17 \quad 94$

$\begin{array}{llll}\text { Moss } & 46 & 12-65 & 100\end{array}$

\section{Forage Production (KG/HA)}

\author{
GRASS 243 \\ FORB 433 \\ SHRUB 30 \\ TOTAL $706 *$ ESTIMATE
}
SUGGESTED GRAZING CAPACITY $2.7 \mathrm{HA} / \mathrm{AUM}$




\section{Literature cited}

Archibald, J.H., G.D. Klappstein and I.G.W. Corns. 1996. Field guide to ecosites of Southwestern Alberta. Nat. Resour.Can., Can. For. Serv., Northwestern Reg., North. For. Cent., Edmonton, Alberta. Spec. Rep. 8.

Bailey, A.W., M.G. Willoughby, R. Johansen and S. Smith. 1992. Management of Yukon Rangelands. Renewable Resources, Yukon Territorial Government, Whitehorse, Yukon. 55pp. ISBN- 1-55018-138-6.

Beckingham, J.D. 1994. Field guide to the ecosystems of Northern Alberta. Environmental Protection, Land and Forest Services, Edmonton, Alta. 352pp.

Beckingham, J.D., I.G.W. Corns and J.H. Archibald. 1996. Field guide to ecosites of Westcentral Alberta. Canadian Forest Service. Northwest Region. Northern Forestry Center. Special Report 9.

Bork, E. 1990. Clearwater allotment.: Prescribed burn vegetation survey, evaluation, and discussion. Range Management Section. Alberta Forest Service. Edmonton. AB. 29pp.

Corns, I.G.W. and P.L. Achuff. 1982.Vegetation, Chapter III. In W.D. Holland and G.M. Coen (editors). Ecological (Biophysical) Land Classification of Banff and Jasper National Parks: Vol. II: Soils and Vegetation Resources. Editor,. Alberta Institute of Technology, Publication no. SS-82-44. 71-156.

Corns, I.G.W. and R.M. Annas. 1986. Field guide to forest ecosystems of West-Central Alberta. Northern Forestry Center, Canadian Forestry Service, Edmonton, Alta. 251pp.

Coupland, R.T. 1961. A reconsideration of grassland classification in the Northern Great Plains of North American. J. Ecology. 49:135-167.

Craighead, J.J., F.C. Craighead and R.J. Davis. 1963. A field guide to Rocky Mountain wildflowers. Peterson field guide series. Houghton Mifflin Company, Boston. 277pp.

Daubenmire, R. 1952. Forest vegetation of Northern Idaho and adjacent Washington and its bearing on concepts of vegetation classification. Ecol. Mongr. 22: 301-330.

Daubenmire, R. 1978. Plant Geography. Academic Press. San Francisco. 338pp.

Environmental Protection. 1994. Natural Regions of Alberta. Publication no. I/531.

Gauch, H.G. 1982. Multivariate analysis in community ecology. Cambridge University Press, 
Cambridge, 298pp.

Gerling, H.S., M.G. Willoughby, A. Schoept, K.E. Tannas and C.A. Tannas. 1996. A guide to using native plants on distrubed lands. Alberta, Agriculture, Food and Rural Development and Environmental Protection. ISBN 0-7732-6125-7 245 pp.

Green, A. and A.L. van Ryswyk. 1982. Chernozems: Their Characterization and Distribution. .In A.C. Nicholson, A. McLean and T.E. Baker (editors) Grassland Ecology and Classification Symposium Proceedings. British Columbia Ministry of Forests, Victoria, B.C. Publication no. R28-82060. pp 249-264.

Greenlee, G.M. 1981. Soil survey of Cypress Hills, Alberta and interpretation for recreational use. Earth Sciences Report 80-4. Alberta Research Council.

Jaques, D. and J. Corbin. 1981. Shrub communities in the Elbow and Sheep River drainages, Kananaskis Country, Alberta: their floristic composition, distribution and browse availability/use by animals. Kananaskis Centre for Environmental Research. University of Calgary, Alberta, Canada.

Johnston, C.G. 1981. Synecological relationships in the Billy Meadows area, Wallowa-Whitman National Forest. U.S.For. Serv. Spec. Rep. Baker Oregon.

Kuchar, P. 1973. Habitat types of Waterton Lakes National Park. Alberta Energy and Natural Resources. $301 \mathrm{pp}$.

Lane, C.T., M.G. Willoughby and M.J. Alexander. 2000. Range plant community types and carrying capacity for the Lower Foothills subregion. $3^{\text {rd }}$ Approximation. Alberta Environment. Land and Forest Service. Pub. No. T/532. 232pp.

La Roi, G.H. and R.J. Hnatiuk. 1980. The Pinus contorta forest of Banff and Jasper National Parks: a study in comparative synecology and syntaxonomy. Ecol. Mongr. 50:1-29.

MacKinnon, A., J. Pojar and R. Coupe (eds). 1992. Plants of Northern British Columbia. Lone Pine Publishing, Edmonton, Alberta.

Morgantini, L.E. and W.B. Russell. 1983. An assessement of three selected elk winter ranges in t he Rocky Mountains Region. Alberta Fish and Wildlife. Edmonton, AB. 265 pp.

Moss, E.H. and J.A. Campbell. 1947. The fescue grassland of Alberta. Can. J. Res. 25:209-227.

Moss, E. H. 1955. The vegetation of Alberta. Bot. Rev. 21: 493-567.

Moss, E.H. 1992. Flora of Alberta. University of Toronto Press. Toronto. 687pp. 
Mueggler, W.F. 1988. Aspen community types of the Intermountain Region. U.S.D.A. Intermountain Research Station. INT-250.133pp.

Mueggler, W.F. and W.L. Stewart. 1980. Grassland and shrubland habitat types of Western Montana. U.S.D.A. Intermoutain Research Station. INT-166. 155pp.

Pojar, J. 1982. Boreal and Subalpine grasslands of Northern British Columbia. In A.C. Nicholson, A. McLean and T.E. Baker (editors) Grassland Ecology and Classification Symposium Proceedings. British Columbia Ministry of Forests, Victoria, B.C. Publication no. R28-82060. pp 249-264.

Rangeland Resource Information System. 1991. Outline and guide, a proposal. Range Management Section, Alberta Forest Service, Edmonton, Alta. 19pp.

Range Survey Manual. 1992. Range Management Section, Alberta Forest Service. Edmonton, Alta. 39pp.

Stringer, P.W. 1973. An ecological study of grasslands in Banff, Jasper and Waterton National Parks. Can. J. Bot. Vol. 51. 383-411.

Strong, W.L. 1992. Ecoregion and ecodistricts of Alberta. Vol. 1. Alberta Forestry, Lands and Wildlife, Land Information Services Division, Resource Information Branch, Edmonton, Alberta. T/244. 77pp.

Strong, W.L. and H.G. Anderson. 1980. Ecological land classification and evaluation reference manual. Resource Evaluation reference manual. Resource Evaluation Branch, Energy and Natural Resources. Edmonton, Alta. 160pp.

Strong, W.L. and K.R. Leggat. 1992. Ecoregions of Alberta. Alberta Forestry, Lands and Wildlife, Resource Information Branch, Edmonton, Alta. T/245. 77pp.

Strong, W.L. and J.M. Thompson. 1995. Ecodistricts of Alberta: Summary of Biophysical Attributes. Alberta Environmental Protection, Resource Data Division. Edmonton, Alta. Pub. no. T/319. $91 \mathrm{pp}$.

Task Group on Unity in Concepts and Terminology. 1995. New concepts for assessement of rangeland condition. J. range Manage. 48:271-283.

Thompson, W.H. and P.L. Hansen. 2002. Classification and Management of Riparian and Wetland Sites of Alberta's Prairie Biome. Bitterroot Restoration Inc. Corvallis, Montana. $416 \mathrm{pp}$.

Tisdale, E.W. 1982. Grasslands of Western North America: The Pacific Northwest Bunchgrass 
type. In A.C. Nicholson, A. McLean and T.E. Baker (editors) Grassland Ecology and Classification Symposium Proceedings. British Columbia Ministry of Forests, Victoria, B.C. Publication no. R28-82060. pp 223-246.

Tisdale, E.W. 1947. The grasslands of the southern interior of British Columbia. Ecol. 28:346382.

Westoby, M., B. Walker and I. Noy-Meir. 1989. Opportunistic management for rangelands not at equilibrium. J. of Range Manage. 42:266-274.

Willms, W.D., L.M. Rode and B.S. Freeze. 1998. Protein supplementation to enhance the performance of pregnant cows on rough fescue grasslands in winter. Can. J. Anim. Sci. 78: 89-94.

Willoughby, M.G. 1992. Rangeland Reference Areas, Plant communities, ecology and response to grazing in Division 1. Forestry, Lands and Wildlife, Alberta Forest Service, Edmonton, Alta. T/266, 46pp.

Willoughby, M.G. and M.J. Alexander. 2000. A range condition dilemma. Rangelands 22:23-26.

Willoughby, M.G.. 2001. Range plant community types and carrying capacity for the Upper Foothills Subregion. Environmental Protection. Land and Forest Services.

Edmonton, Alberta. Pub. No. T/003 119pp.

Willoughby, M.G. and D. Downing. 1995. Deciduous plant communities and carrying capacity for the Boreal Ecoprovince of Alberta. Alberta Environmental Protection. Edmonton. Publ. no. T/312. 136pp.

Willoughby, M.G. 1995. The effect of grazing on deciduous plant communities in the Boreal Ecoprovince of Alberta. Proc. Fifth Int'l Rangeland Congress, Salt Lake City, Utah. 608609.

Willoughby, M.G. 1999. Range plant community types and carrying capacity for the Subalpine and Alpine subregions. Environmental Protection, Land and Forest Service. Edmonton, Alta. Pub no. T/438. 109 pp.

Willoughby, M.G. 1996. Rangeland reference areas: Castle River range condition and trend from 1953-1995. Environmental Protection, Lands and Forest Services. Edmonton, Alta. 10 pp.

Wroe, R.A., S. Smoliak, B.W. Adams, W.D. Willms and M.L. Anderson. 1988. Guide to range condition and stocking rates for Alberta grasslands. Forestry, Lands and Wildlife, Edmonton, Alta. 33pp. 


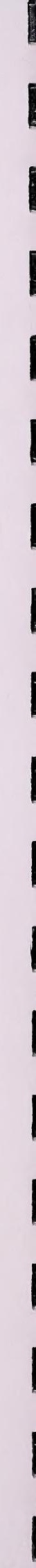



